\title{
A taxonomic revision of the Malesian species of Lasianthus (Rubiaceae)
}

\author{
H. Zhu' ${ }^{1}$, M.C. Roos ${ }^{2}$, C.E. Ridsdale ${ }^{2}$
}

\section{Key words}

Lasiantheae

Lasianthus

Malesia

revision

Rubiaceae

\begin{abstract}
Based on herbarium collections, the Malesian species of the genus Lasianthus are revised. A total of 131 species including 5 subspecies and 6 varieties are recognized from the Malesian region, of which 41 species, 3 subspecies and 3 varieties are described as new, and 3 new combinations are made for varieties. 22 species names and 15 variety names are reduced to synonyms. Ten species names and 2 varieties are treated as dubious mainly because their types cannot be traced. Additionally, 11 species are further excluded from Lasianthus. Al species are described and a key to Malesian Lasianthus is given.
\end{abstract}

Published on 29 May 2012

\section{INTRODUCTION}

Lasianthus Jack is a large genus of the Rubiaceae with more than 180 species, predominantly in the Old World. The greatest species diversity is found in tropical Asia (Robbrecht 1988), where some 160 species occur, only one extending into Australia. The species of the genus occur almost exclusively in the understory of primary forests, and have limited potential for physiological acclimation to high light levels (Cai et al. 2005). There are occasionally records from secondary or seriously disturbed forests or forest edges. Lasianthus species are usually present in large numbers in the tropical forests of Asia and may therefore represent an ecologically important element. The species of Lasianthus also show interesting distribution patterns, which are of special interest for the study of the biogeography of tropical Asia and of prevailing speciation models in tropical rainforests.

The tropical Asian representatives of the genus are regarded to be extremely difficult taxonomically. The flowers and fruits are small and often shed from herbarium specimens. There are only a few diagnostic characters available for delineating the species and the majority of the characters used are quantitative features of the vegetative organs such as leaves, stipules, and bracts. It is therefore difficult to correctly determine a species by referring to old descriptions only. In most herbaria that we visited, misidentifications of Lasianthus specimens were frequent. Quite some earlier species and even newly recognized species have been described from a single type collection or a few collections only. Some types of Korthals' species, which should be in Leiden, could not be traced, while others were destroyed in Berlin during the World War II. Even the holotype of the type species of the genus $L$. cyanocarpus was destroyed by a fire in 1824 (Merrill 1952).

About 140 species names and numerous varieties were published based on Malesian collections (see below, Taxonomic History). All of these names except two were published before

\footnotetext{
Xishuangbanna Tropical Botanical Garden, The Chinese Academy of Sciences, Kunming 650223, P.R. China; corresponding author e-mail: zhuh@xtbg.ac.cn.

2 Netherlands Centre for Biodiversity Naturalis (section NHN), Leiden Uni-
} versity, P.O. Box 9514, 2300 RA Leiden, The Netherlands.
1938. Since 1950, many more specimens from the Malesian region have been collected, but a synopsis on the genus for Malesia has not been made so far, except for two regional flora treatments, i.e. Bakhuizen van den Brink (1965) for Java (treating 29 species including 2 provisional names) and Wong (1989) for the Peninsular Malaysia (dealing with 54 species including 8 unnamed ones). Therefore, the present revision of Lasianthus from Malesia is most needed. Here we recognize 131 species from the Malesian region, of which 41 species, 3 subspecies and 3 varieties are described as new, and 3 new combinations are made for varieties. 22 species names and 15 variety names are reduced to synonyms. 10 species names and 2 varieties are treated as dubious mainly because their types could not be traced. Additionally, 11 species are excluded from Lasianthus.

\section{METHODS}

This paper is a classic taxonomic revision on the genus Lasianthus for Malesian species based mainly on morphological characters. The authors examined all collections from the Malesian region in $\mathrm{AAU}, \mathrm{BM}, \mathrm{K}, \mathrm{L}$, and $\mathrm{U}$, and a selection of the Malesian collections in the herbaria BKF, KEP, MO, and SING. Type specimens in C, E, HBG, NY, P, SING, US have also been checked. The species presentation is in alphabetical order. The arrangement of synonyms is organized chronologically in homotypic paragraphs. All cited specimens are examined by the authors except a few type specimens which are indicated as 'n.v.'.

In total, all c. 3600 specimens in $\mathrm{K}$ and $\mathrm{L}$ were examined. Additional specimens from $A A U$ received on loan were also examined. More than $95 \%$ of the Lasianthus collections in $\mathrm{K}$ and $L$ have been identified for the present study. A small number of specimens, which do not belong to the species presently recognized, could not be treated because of imperfect state (lacking complete flowers or fruits). All published names from the Malesian region are covered in the present work. Nomenclature and typification follow the International Code of Botanical Nomenclature (McNeill et al. 2006). Lectotypifications for some of Blume's species are made. Neotypifications are also made for some species of which we could not trace type materials and which are most probably lost. 


\section{TAXONOMIC HISTORY}

\section{Generic delimitation}

Lasianthus Jack was established in 1823 based on two Sumatran species, Lasianthus cyanocarpus (later selected as the type of the genus; see below) and Lasianthus attenuatus. In the same year Blume (1823) listed several plant species under the genus name Mephitidia attributed to Reinwardt but described one species $M$. hexandra himself. The genus was redescribed two years later by Reinwardt (1825), but no species were mentioned by him. According to the International Code of Botanical Nomenclature (McNeill et al. 2006), the genus Mephitidia is attributed to Reinwardt ex Blume with $M$. hexandra Blume as type. Blume (1826-1827) realized that Mephitidia was synonymous with Lasianthus Jack and provided accounts of the Javanese species. Mephitidia continued to be used by some authors because they were aware of an earlier publication of Lasianthus Adans. (= Gordonia) for a genus in the Theaceae. De Candolle (1830) was the most significant of these authors and Korthals (1851) was the last author to use Mephitidia for the Malesian species in taxonomic publications. Later, Lasianthus Jack has been conserved for the genus treated here.

Blume (1823) described from Java a monotypic genus Litosanthes, which is closely related to Lasianthus. Inherently Ridley (1923a) reduced this genus to a section of Lasianthus, however Bakhuizen van den Brink (1965) retained Litosanthes as a separate genus based on three characters: imbricate corolla, forked stipules, and pedunculate inflorescences. Deb \& Gangopadhyay (1991) transferred some Indian taxa to Litosanthes, but subsequently Gangopadhyay \& Chakrabarty (1992) reduced these taxa of Litosanthes to a section of Lasianthus (see section below).

The circumscription of Lasianthus Jack was more or less modified by later authors, especially referring to the number of ovary locules or pyrenes. In Jack's description Lasianthus has ovaries with 4 locules each with a single basal erect ovule, which normally develops into a drupe with 4 pyrenes. Blume (1826-1827) followed Jack's view, but described more variation based on more Malesian species: 4-9 locules and a drupe with 4-9 pyrenes. Wight (1846) modified the genus by adding a species with a 2-locular ovary and drupes with 2 pyrenes $(L$. foetens Wight $=$ Saprosma foetens (Wight) K.Schum. (1891)). Korthals (1851) established a subgenus of Dysosmia based on a Javanese species Mephitidia dichotoma Korth., which has a 2-locular ovary and a compressed bi-pyrened drupe with a thin wall. Miquel (1857) raised it to generic rank as Dysosmia Korth., and consolidated the circumscription of Lasianthus Jack based on Blume's definition. Boerlage (1891) reduced Dysosmia Korth. to Saprosma. Baillon (1880), reputed for his wide generic concepts in general, enlarged Lasianthus Jack and moved the African genus Saldinia under Lasianthus Jack as a subgenus. Saldinia has a 2-locular ovary, which develops into a drupe with a single hard-walled pyrene. Bremekamp (1957) made a combination L. furcatus (Miq.) Bremek. based on Canthium furcatum Miq., and he sank Saprosma dichotomum (Korth.) Boerl. in L. furcatus. Dysosmia was again returned to Lasianthus by Bremekamp (1957) because its type is Saprosma dichotomum. Meanwhile, Bremekamp (1957) restored Saldinia and gave a new definition to Lasianthus as having 2-more locules in the ovary and drupes with $2-$ more pyrenes with a relatively soft wall (against Saldinia). Subsequently, some confusion emerged. A group of Asian species, which has 2-locular ovaries with a single basal erect ovule in each locule, and drupes with 2 pyrenes with a thin wall, as well as usually leaves with a looped venation, were treated in several different genera. Some of these species were treated as Lasianthus, some as Saprosma and some as Amaracarpus (Valeton 1911, Davis \& Bridson 2004).
Lasianthus as defined here has drupes or pyrenes with a thick wall. Species that show drupes with a thin wall (and do not belong to Saprosma nor Amaracarpus), are here treated as dubious taxa. Their systematic position needs further study. Piesschaert (2001) studied the carpology of Psychotrieae and gave a definition of Lasianthus as having a gynoecium with 4-12 locules that develops into a drupe with 4-12 pyrenes. In our present treatment, we restrict Lasianthus to species with drupes with 2-9 mature pyrenes with a thick wall that develop from ovaries with 2-9 locules for the Asian representatives. Petit (1964) and Denys (1981) discussed that African species have pyrenes with a pre-formed oval to circular germination lid that could easily removed. However, for Asian species, few studies of the germination lids of pyrenes have been carried out.

\section{Delimitation of the species}

The African taxa have to some extent been treated by Verdcourt (1976) for tropical East Africa. Denys (1981) revised the genus for Central Africa. There seems to be less work on the three American species, however, Robbrecht (1982) commented upon two of these on the occasion of a discussion of the synonymy of the Panamanian endemic genus Dressleriopsis.

Important for mainland SE Asia is the work of Hooker (1880) who recognized some 52 species and placed them all in a subgeneric classification (see below, Infrageneric Classification). Subsequently regional flora accounts were produced for former 'Indo-Chine' (Pitard 1924) and for Thailand (Craib 1934). Later Yamazaki (1964) revised the genus for the Ryukyu Islands and Liu \& Chao (1964) treated the Taiwanese species. Zhu (1994, 2002) treated the Chinese Lasianthus and then revised the genus for Thailand (Zhu 2001b). The taxa from the Indian subcontinent have received considerable attention in recent years: Deb \& Gangopadhyay $(1989,1991)$ for India and Ridsdale (1998) for Sri Lanka.

The species of the genus from the Malesian region were studied by many authors: Java (Blume (1826-1827, types in L; Bakhuizen van den Brink 1963, types in L); Java, Sumatra and, Borneo (Korthals 1851, types not found; Miquel 1857, 1861, 1869, types in $U$ and L); Borneo (Stapf 1894, types in K, SING; Merrill 1929a, 1937, holotypes in HBG, isotypes in NY); Peninsular Malaysia (King \& Gamble 1904, types mainly in SING and K, fewer in U and L; Ridley 1909, 1910, 1912, 1917a, b, 1918, 1920, 1923a, b, types in K and SING; Wong 1989); the Philippines (Elmer 1906a, b, 1908, 1911, 1912, 1913, 1934a, b, holotypes in PNH†, isotypes dispersed in A, E, K, L, MO, NY, P, U, US; Merrill 1908a, b, 1922, 1923, holotypes in $\mathrm{PNH}$, isotypes dispersed in $\mathrm{A}, \mathrm{K}, \mathrm{L}, \mathrm{MO}, \mathrm{NY}, \mathrm{P}, \mathrm{U}, \mathrm{US}$ ); New Guinea (Lauterbach 1905, holotype could be in WRSL; Schumann 1905, type in B†; Valeton 1911, 1927, type mainly in B十, fewer in L, S; Wernham 1914, 1916, 1918, types in BM).

\section{Infrageneric classification}

The first apparent attempt to subdivide the genus (Wight 1846) created two subdivisions 'Bracteosae' and 'Nudiflorae', without rank and not typified. These two names were taken over by Hooker (1880) and given the rank of section: Bracteatae and Nudiflorae. Hooker described two further sections 'Stipulares' typified by $L$. stipularis Blume and a non-typified section ' $P e$ dunculatae'. Hooker placed two of the species of Wight's group 'Nudiflorae' into this section hence only one of the original species remained in 'Nudiflorae', i.e. L. blumeanus which is the type of the section. The type species of Lasianthus, L. cyanocarpus, is in the sect. Bracteatae and hence this is a superfluous name for sect. Lasianthus.

Ridley (1923a) confused the issue further, the section including the type species also contained the species of sect. Stipulares 
and was incorrectly called 'Eu-Lasianthus' and two further sections were added. These have names formerly used at generic level, 'Mephitidia' and 'Litosanthes'. There was no further reference to the origin of these names in the text but it is reasonable to assume that these refer to the genera of the same name and that the typification is the same. These Javanese species were unknown in the Peninsular Malaysia and not treated directly by Ridley. Section Mephitidia, which has bracts inconspicuous or absent, is apparently the same as sect. Nudiflorae of Hooker, and sect. Litosanthes, which has forked stipules and pedunculate inflorescences, is the same as sect. Pedunculatae of Hooker. Finally, Gangopadhyay \& Chakrabarty (1992) reduced the taxa included in Litosanthes back to a section of Lasianthus where Hooker's section Pedunculatae was the oldest available name at that level. They further chose L. biermannii King ex Hook.f. as the lectotype species of this section.

We accept here a division in three sections.

\section{The position in Rubiaceae}

In one of the classical subfamilial classifications of the Rubiaceae (Hooker 1873), Lasianthus is placed in the tribe Psychotrieae, based on the valvate aestivation of the corolla lobes and a single, basally attached ovule in each of the ovary locules. Schumann (1891) followed Hooker and retained the genus in the Psychotrieae.

Petit (1964) proposed new definitions for the Psychotrieae and Morindeae, based especially on seed characters. He defined Psychotrieae as having seeds with horny endosperm and small embryos whilst the Morindeae have seeds with soft oily endosperm and large embryos. Petit therefore transferred $\mathrm{La}$ sianthus to the Morindeae. Petit's placement was followed by Verdcourt (1976) and Robbrecht (1988). However, Igersheim \& Robbrecht (1993) narrowed the delimitation of the Morindeae, and Lasianthus was excluded to an uncertain position.

Recent molecular work has indicated further possible relationships. Bremer (1996), working with sequences of the chloroplast gene $r b c \mathrm{~L}$, reported that Lasianthus forms a single clade with Pauridiantha Hook.f. with high bootstrap support values. This is very surprising in view of morphological differences as Pauridiantha has a quite different fruit, berry-like and containing a large number of seeds. Andersson \& Rova (1999) sequenced the rps 16 intron to investigate the phylogeny of the Rubioideae - the subfamily wherein Psychotrieae and Morindeae are placed in current systems (e.g. Robbrecht \& Manen 2006). In their results Lasianthus groups together with the neotropical genus Perama Aubl. on a strongly supported branch, again in spite of morphological differences with Perama. Andersson \& Rova (1999) suggested that Lasianthus should be added to the monogeneric tribe Perameae Bremek. ex Darwin, of which the position was previously uncertain as well (Robbrecht 1988). Bremer \& Manen (2000), combining the results from the protein coding $r b c \mathrm{~L}$ gene, the spacer sequence between atpB and $r b c \mathrm{~L}$, and Andersson \& Rova's rps16 intron data, suggested a new tribe Lasiantheae B.Bremer \& Manen to include Lasianthus and Trichostachys Hook.f., the latter formerly placed in the Morindeae. Based on the chloroplast rps16 intron sequence, a phylogenetic analysis of Lasianthus was made by Xiao \& Zhu (2007). Contrary to Andersson \& Rova (1999), they did include Saldinia A.Rich. and Trichostachys, and in their results Lasianthus, Saldinia and Trichostachys form a strongly supported branch, with Perama as their sistergroup. In fact, Xiao \& Zhu's (2007) results are compatible with those of Andersson \& Rova (1999). Piesschaert et al. (2000) added seven more genera of Rubioideae to the morphological and molecular matrix and following their cladistic analysis Lasianthus, Saldinia and Trichostachys form a closely related group and Perama is more distantly related to this group.
Piesschaert et al. (2000) also found additional morphological and anatomical characters to support Petit's (1964) ideas on the tribal characters of the Psychotrieae and Morindeae. The Psychotrieae mostly have terminal inflorescences, wood with radial multiple vessels, and seeds with small embryos and horny (not oily) endosperm. Lasianthus differs from the Psychotrieae in having axillary inflorescences paired at the nodes, solitary vessels, large embryos and soft oily endosperm. The latter seed characters are shared with the Morindeae which however, have biovulate locules and the ovules attached to the middle of the septum. Lasianthus has uniovulate locules and the ovules are attached at the base in the corner of the locule.

In conclusion, the abovementioned molecular analyses brought the novel view that Lasianthus separates on a branch independent from both the Psychotrieae and Morindeae. The suggestion to recognize the group of genera Lasianthus, Saldinia and Trichostachys at the tribal level is well supported by molecular and morphological characters. Lasianthus, Saldinia and Trichostachys form a strongly supported branch in the 'basal Rubioideae'. Further investigation is required to decide upon the position of Perama. Pending further clarification on this point it seems logical to accept the tribe Lasiantheae B.Bremer \& Manen.

\section{MORPHOLOGY}

\section{Life form}

Lasianthus species are usually shrubs, but some are understory shrubs or grow into small trees (treelets); some African and American species are creeping plants. Generally they have a monopodial axis with lateral plagiotropic shoots.

\section{Indumentum}

An indumentum is often present on the branchlets, petioles, the lower surface of the leaves, especially on midribs and veins, as well as on the stipules in many of the species, and if present, it is of diagnostic importance. Some species are almost glabrous, such as L. laevigatus, $L$. laxiflorus, and $L$. lucidus. A few species have a variable indumentum: young branchlets and the lower surface of leaves are hairy to subglabrous or glabrous, which has led to the separation of varieties. Stiff hairs (stiff and rough hairs) are found in L. hirsutus; hirsute hairs (rough hairs) in L. chrysotrichus, L. cyanocarpoides; villous hairs (dense, long and soft hairs) in L. curtisii, L. hirtus, L. hispidulus, L. sikkimensis and others; pubescence (short, dense and usually appressed hairs) in L. bracteolatus, L. chrysoneurus, L. chrysophyllus, L. clementis, L. euneurus, L. obliquinervis and others; very short and thin pubescence in $L$. chinensis, $L$. stercorarius; strigillose hairs (spreading rough hairs) in L. chlorocarpus, L. trichophlebus; hispid hairs (stiff, rough and spreading hairs) in L. borneensis, $L$. setulosus; tomentose hairs (dense, relatively short and spreading hairs) in L. chryseus, L. ferrugineus, L. tomentosus, $L$. undulatus and others. The species $L$. chrysoneurus differs from $L$. obscurus by having appressed-pubescent vs tomentose indumentum. Lasianthus hispidulus separates from L. clementis by only having villose vs appressed-pubescent indumentum. However, the different types of hairs are sometimes hard to distinguish, and it turns out that different concepts of hair type were used by the various authors. Here we delimit hair types as explained above.

\section{Leaf size, shape and texture}

The foliage varies in shape and size in the genus. Some species have relatively small leaf-blades less than $10 \mathrm{~cm}$ long, such as $L$. appressus, $L$. curtisii, L. lucidus. Lasianthus bifloroideus and $L$. biflorus have the smallest leaf-blades, less than $3 \mathrm{~cm}$ long. Some have leaf-blades longer than $15 \mathrm{~cm}$, such as 
L. chinensis and L. hirsutus. Several Bornean species have leaf-blades which are even more than $25 \mathrm{~cm}$ long, such as $L$. longibracteatus and L. megaphyllus. Most species have oblong leaf-blades, but $L$. linearifolius has linear leaf-blades. The leaf apex is usually cuspidate-acuminate or acute, but caudate in $L$. dinghouanus and L. linearifolius. Most species have cuneate or acute leaf bases, but $L$. attenuatus, $L$. cyanocarpus and $L$. rigidus have oblique, cordate or rounded bases. Leaf texture varies from chartaceous to coriaceous. Lasianthus tenuifolius has thinly chartaceous leaf-blades; leaves of $L$. mucronulatus and $L$. oblongatus are chartaceous, while those of $L$. inodorus and $L$. vriesianus are coriaceous. The petiole varies from subsessile to several $\mathrm{cm}$ long.

\section{Leaf blade venation}

Venation and the number of secondary veins are of some diagnostic value. The veinlets (nervules) are of more diagnostic importance. Lasianthus brochidodromus, L. kinabaluensis and $L$. membranaceoideus have looped venation, while most Lasianthus species have open venation. Lasianthus chinensis and $L$. verticillatus are two easily confused species, however $L$. chinensis has leaves with more than 10 pairs of nerves and reticulate nervules, while $L$. verticillatus has leaves with less than 10 pairs of nerves and (as most species) parallel nervules. Lasianthus malaccensis and $L$. wightianus have conspicuously reticulate nervules. Lasianthus euneurus and L. verticillatus have parallel nervules. Lasianthus subaureus separates from $L$. verticillatus mainly by having reticulate nervules vs parallel nervules. However, some species have nervules between parallel and reticulate, termed subparallel and subreticulate, respectively. The venation is usually prominent beneath, but in some species prominent on both surfaces. Several species have faint and obscure nervules.

\section{Stipules}

The size and shape of the interpetiolar stipules are of diagnostic value within the genus. Lasianthus longifolius, L. obscurus, $L$. trichoplebus and $L$. venosus have relatively large (more than $5 \mathrm{~mm}$ long), triangular or lanceolate stipules. Other species have minute, inconspicuous stipules. Lasianthus stercorarius and $L$. vulcanicus have stipules with a swollen base.

\section{Inflorescences}

The inflorescences are axillary and paired at the nodes, sessile and fascicled, or pedunculate cymes. Bracts or bracteoles are present and persistent, or absent. The diagnostic importance of bracts and peduncles was emphasized by Hooker (1880). For example, L. chevalieri Pit. from mainland SE Asia is separated from $L$. capitatus from Indonesia mainly by the sessile inflorescence. Lasianthus laxiflorus, $L$. pendulus and $L$. robinsonii have peduncles longer than $3 \mathrm{~cm}$, whereas $L$. brevipedunculatus and $L$. pergamaceus have peduncles which are only 1-3 mm long. However, length variation of the peduncles sometimes reduces its diagnostic importance. For example, $L$. capitatus and $L$. rhinocerotis have inflorescences pedunculate or subsessile. Some species, such as $L$. congesticymus and $L$. reticulatus have inflorescences extremely congested. Bracts are notably orbicular and coriaceous in $L$. inodorus; ovate to lanceolate in $L$. chrysoneurus and $L$. obscurus; linear or lanceolate in $L$. attenuatus, $L$. rigidus, and L. sikkimensis; leaf-like in $L$. cyanocarpus and $L$. hirsutus, or inconspicuous or absent in L. chinensis, L. curtisii, L. Iucidus, and L. tomentosus.

\section{Flowers}

The flowers are usually small, from several $\mathrm{mm}$ to a maximum of $2.5 \mathrm{~cm}$ long (only seen in L. longifolius). In most species they are sessile, but the flowers of $L$. brevipedicellatus, $L$. oblongus, $L$. pedicellatus, and $L$. purpureus are more or less conspicuously stalked. Some species have 4-merous flowers, such as $L$. floresensis, L. ridsdalei, and L. trichophlebus. Many species have 5-merous flowers. The calyx has more diagnostic characters. As it is persistent, its features can also be used for identifying material in fruiting stage. Lasianthus chrysotrichus, $L$. curtisii, and $L$. hexandrus have a calyx that is divided nearly to the base. Lasianthus lucidus, L. ridsdalei, and L. sylvestroides have calyx lobes which are conspicuously longer than the calyx tubes. Many species have calyx lobes which are nearly as long as the calyx tubes or shorter than the calyx tubes but still conspicuous. Lasianthus fordii and $L$. hispidulus have a calyx limb with 5 minute, triangular teeth. Lasianthus longifolius, $L$. subaureus, and $L$. verticillatus have cupular truncate calyx limbs or minute teeth at the apex. However, the length of calyx lobes is not always constant. In a few species, for example L. fordii, the calyx teeth can be variable.

The corolla is easily lost when preparing specimens, and not often used for diagnostic character, because it is poorly known for many species. Imbricate corolla lobes were used as one of the characteristics for moving sect. Pedunculatae Hook.f. of Lasianthus to Litosanthes Blume by Deb \& Gangopadhyay $(1989,1991)$. However, both imbricate and valvate corolla lobes

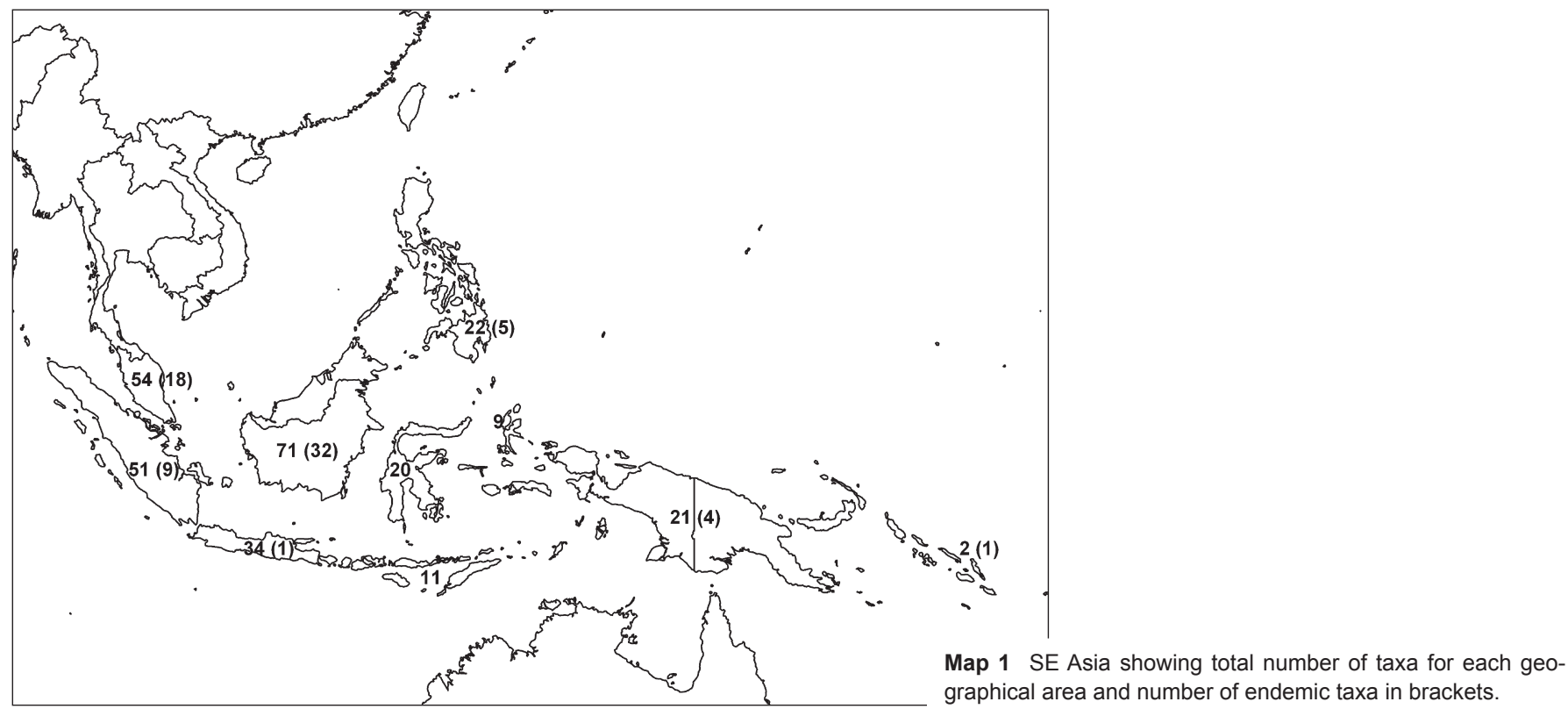


Table 1 Geographical distribution of Malesian Lasianthus.

\begin{tabular}{lcc}
\hline Biogeographical area & Number of total taxa* & Number of endemic taxa* \\
\hline Borneo & 71 & 32 \\
Peninsular Malaysia & 54 & 18 \\
Sumatra & 51 & 9 \\
Java & 34 & 1 \\
Philippines & 22 & 5 \\
New Guinea & 21 & 4 \\
Sulawesi & 20 & 0 \\
Lesser Sunda Islands & 11 & 0 \\
Moluccas & 9 & 0 \\
Solomon Islands & 2 & 1
\end{tabular}

Solomon Islands

\section{Country}

Malaysia

Indonesia

Brunei

Philippines

Papua New Guinea

Singapore

Solomon Islands

* Species, subspecies and varieties together.

are observed in species of sect. Pedunculatae. The systematic significance of corolla aestivation is limited, whereas the shape of the stamens and the ovary are rarely used as diagnostic characters. However, the number of ovary locules is of importance in separating Lasianthus from closely related genera.

\section{Fruits}

Fruits are drupes crowned (as already mentioned above) by persistent calyx lobes. Indumentum, surface texture (smooth or warty) and morphology (ridged or not ridged and the number of ridges) of the dry fruits are more of diagnostic importance. The ridges correspond to the number of pyrenes and are especially obvious in immature seeds or seeds from herbarium material. The fruits with a thick wall and 1-9 mature pyrenes (Asian species) develop from ovaries with 3-9 locules. The surface characters of the pyrene wall and cross section are of important diagnostic value. However, in the present revision, the number of pyrenes is often used as it is relatively easy to observe, wall characters only when no other diagnostic characters are available.

\section{BIOGEOGRAPHY}

With regard to the geographical regions as recognized by Van Steenis (1950) and Van Welzen \& Slik (2009), Borneo with 71 taxa (including subspecies and varieties), is the most biodiverse area, followed by Peninsular Malaysia with 54 taxa. Next come Sumatra with 51 taxa, Java with 43 taxa, and the Philippines with 22 taxa. In terms of endemicity, Borneo comes first again, housing 32 taxa, once more followed by Peninsular Malaysia with 18 taxa, Sumatra with 9 taxa, and the Philippines with 5 taxa (see Table 1 and Map 1).

\section{TAXONOMIC TREATMENT}

\section{Lasianthus}

Lasianthus Jack (1823) 125, nom. cons.; Blume (1826-1827) 995; Spreng. (1830) 94; Wight (1846) 498; Miq. (1857) 314; Hook.f. (1873) 129; Kurz (1877) 30; Hiern (1877) 228; Hook.f. (1880) 178; K.Schum. (1891) 120; Prain (1903) 576; Ridl. (1923a) 149; Pit. (1924) 371; Valeton (1927) 105; Craib (1934) 207; FI. Hainan 3 (1974) 333; T.S.Liu \& J.M.Chao (1964) 118; Bakh.f. (1965) 335; K.M.Wong (1988) 367; Deb \& M.Gangop. (1991) 270; H.Zhu (1994) 49; (2001b) 124; (2002) 69. - Type: Lasianthus cyanocarpus Jack (typ. cons.).

Dasus Lour. (1790) 141, nom. rej. - Type: Dasus verticillata Lour. (= Lasianthus verticillatus (Lour.) Merr.)
Mephitidia Reinw. ex Blume (1823) 51. - Type: Mephitidia hexandra Blume (= Lasianthus hexandrus (Blume) Blume).

Litosanthes Blume (1823) 22; (1826-1827) 994. — Type: Litosanthes biflora Blume.

Santia Wight \& Arn. (1834) 422, nom. illeg., non Santia Savi 1799. - Type: Santia venulosa Wight \& Arn. (= Lasianthus venulosus (Wight \& Arn.) Wight)

Subshrubs, shrubs, or rarely small trees, foetid or not. Branches and branchlets terete, sometimes compressed, rarely fistulous; lenticels inconspicuous or conspicuous. Leaves opposite, distichous, usually thinly coriaceous or chartaceous; apex acuminate, acute or cuspidate; base acute to rounded or cordate; midrib flat, depressed or slightly prominent above, usually prominent beneath; nerves generally prominent beneath, ascending at an angle of more than $45^{\circ}$, curved to the margin or joining the nerves above at margin; nervules parallel or reticulate. Stipules interpetiolar, usually persistent, well developed or inconspicuous, triangular, lanceolate, ovate or oblong; apex acute or obtuse. Inflorescences axillary, rarely supraaxillary, opposite, sessile, compact or cymes with peduncles, several-flowered to many-flowered; peduncles conspicuous or compressed, stout to extremely congested; bracts persistent or not, well developed or absent. Flowers small, white, sessile or pedicellate, in clusters or peduncled cymes axillary and paired at the nodes; calyx campanulate, with 3-6 teeth or lobes, rarely with cupular limb truncate at apex, persistent on fruit; corolla funnel-form or salver-shaped, several $\mathrm{mm}$ long to the maximum of $2.5 \mathrm{~cm}$ long, glabrous or hairy outside; the throat usually villous inside; the lobes 4-6, valvate or imbricate in bud; stamens 4-6, inserted on the throat of the corolla; filaments short; the anthers linear or oblong, dorsifixed, included or exserted; style linear, with 3-9 linear or lanceolate stigmas lobes; ovary 3-9-celled; ovules 1 in each cell, basal, erect. Fruit drupes small, pulpy, blue, or rarely white, black or red, usually globose, smooth or warty, rounded or ridged; pyrenes 2-9, thick walled, smooth, warty or sulcate on the abaxial face, usually triangular in transverse section.

Distribution - More than 180 species in tropical areas of the world, and centred in tropical Asia. There are more than 160 species in tropical Asia, c. 20 species in Africa, 1 in Australia and 3 in tropical America.

Note - Hooker's (1880) infrageneric system has been commonly accepted although there is not an exclusive character for any of the sections. Stipules, bracts and peduncles, which are key characteristics to separate sections in Hooker's system, vary from species to species gradually in size and shape. However, some correlation among these characteristics can be seen indeed. Large stipules (large enough to cover or partly cover the inflorescence) are correlated with the sessile inflorescence and numerous bracts except for two species in which the bracts are reduced. The sect. Stipulares so defined seems a natural group. The sect. Nudiflorae, which has sessile or subsessile inflorescences and inconspicuous bracts except one species with very short peduncles, can be recognised as a loose group. The sect. Lasianthus, which has sessile cymes accompanied by conspicuous bracts, cannot be clearly separated from the sect. Pedunculatae, which has peduncled cymes, because there is a group of species with conspicuous peduncles accompanied by conspicuous bracts, such as L. moonii, L. pendulus, L. rhinocerotis. Here we therefore reduce the sect. Pedunculatae to the sect. Lasianthus.

\section{Key to the sections}

1. Stipules quite large, ovate, oblong-ovate or triangular-ovate, coriaceous with membranaceous margin or membranaceous, partly or completely covering the sessile cymes . . .................... . sect. I. Stipulares 
1. Stipules large or small, triangular, lanceolate, oblong, rarely ovate, never large enough to cover or partly cover cymes 2

2. Bracts conspicuous, linear-lanceolate, ovate, cordate or leaf-like, more that $3 \mathrm{~mm}$ long . . . . . . sect. II. Lasianthus

2. Bracts inconspicuous or absent, or minute, linear, usually less than $3 \mathrm{~mm}$ long ............ sect. III. Nudiflorae

\section{Sect. I. Stipulares Hook.f. (1880) 179. — Type: Lasianthus stipularis Wight}

\section{Key to the species}

1. Stipules completely or almost covering the cymes, bracts not forming a dense and thick head if existent; leaves less than $16 \mathrm{~cm}$ long with $6-11$ pairs of nerves . . . . . . 2

1. Stipules partly covering the cymes, bracts forming a dense and thick head; leaves usually longer than $16 \mathrm{~cm}$ with more than 12 pairs of nerves ... . . . . . . . 53. L. griffithii

2. Bracts numerous, longer than $5 \mathrm{~mm} \ldots \ldots \ldots \ldots . . .3$

2. Bracts few, less than $5 \mathrm{~mm}$ long $\ldots \ldots \ldots \ldots \ldots \ldots 4$

3. Bracts linear to narrowly lanceolate, up to $1.5 \mathrm{~cm}$ long, villous . . . . . . . . . . . . . . . . 117. L. stipularis

3. Bracts ovate-triangular to lanceolate, $7-8 \mathrm{~mm}$ long, glabrous except hairy margins . . . . . . . . . . 52. L. glaber

4. Branchlets and leaves glabrous; leaves oblong; calyx with a shallowly cupular limb, truncate or minute-teethed at apex 100. L. pseudo-stipularis

4. Branchlets hirsute; leaves ovate-elliptic with hirsute nerves beneath; calyx without a shallowly cupular limb but with lanceolate lobes with barbate hairs at margin 9. L. barbiger

\section{Sect. II. Lasianthus}

- sect. Bracteatae Hook.f. (1880) 179, nom. illeg. - Type: Lasianthus cyanocarpus Jack.

- sect. Pedunculatae Hook.f. (1880) 190. - Type: Lasianthus biermannii King ex Hook.f. (lecto, designated by Gangopadhyay \& Chakrabarty 1992).

\section{Key to the species}

1. Cymes sessile, subsessile or shortly tuberculate .... 2

1. Cymes conspicuously pedunculate, peduncles more than $1 \mathrm{~mm}$ long . . . . . . . . . . . . . . . . . 31

2. Bracts longer than $5 \mathrm{~mm} \ldots \ldots \ldots \ldots \ldots \ldots \ldots$

2. Bracts shorter than $5 \mathrm{~mm} \ldots \ldots \ldots \ldots \ldots \ldots$

3. Leaves with subcordate or rounded, more or less oblique bases . . . . . . . . . . . . . . . . . . . . 4

3. Leaves with cuneate or acute, equal-sided bases. . . . . 9

4. Leaf nerves conspicuously depressed above, 10-13 pairs; drupes glabrous . . . . . . . . . . . . . 33. L. crassinervis

4. Leaf nerves flat or slightly prominent above, usually less than 10 pairs; drupes hairy or glabrous . . . . . . . . 5

5. Plants glabrous; leaves with a faint intramarginal vein; bracts coriaceous, oblong-lanceolate to oblong, obtuse at the apex; calyx lobes oblong to oblong-ovate, obtuse at the apex 30 . L. cordatus

5. At least stipules and bracts hirsute; leaves without an intramarginal vein; bracts chartaceous, not oblong-lanceolate or oblong, acuminate or acute at the apex; calyx lobes triangular or lanceolate, acute or acuminate at the apex $\ldots \ldots 6$

6. Branches glabrous, enlarged (swollen) at nodes; leaves hirsute on midrib and nerves beneath, obovate to obovateoblong, coriaceous; drupes glabrous. ..... 106. L. rigidus

6. Branches usually densely tomentose or villous, not enlarged (swollen) at nodes; leaves usually densely tomentose, villous or setaceous beneath, usually oblong, membranaceous or chartaceous; drupes hairy . . . . . . . . . . 7

7. Branchlets densely spreading villous; bracts paired, with a long linear apex . . . . . . . . . . 113. L. sogerensis

7. Branchlets densely tomentose; hairs not spreading; bracts not paired, but numerous, acuminate . . . . . . . 8

8. Bracts cordate to broadly lanceolate, somewhat leaf-like ... . . . . . . . . . . . . . . . 37. L. cyanocarpus

8. Bracts linear to lanceolate, not leaf-like. .6. L. attenuatus

9. Branchlets and leaves usually stiffly rusty-hirsute; bracts large, cordate, orbicular, ovate or ovate-lanceolate, leaflike, more than $1 \mathrm{~cm}$ broad . . . . . . . . 56. L. hirsutus

9. Branchlets and leaves not stiffly rusty-hirsute; bracts relatively small, oblong-lanceolate, lanceolate, linear or subulate, less than $0.5 \mathrm{~cm}$ broad $\ldots \ldots \ldots \ldots \ldots 10$

10. Bracts oblong-lanceolate or lanceolate, with a conspicuous midrib. . . . . . . . . . . . . . . . . . 11

10. Bracts linear or linear-lanceolate, without a conspicuous

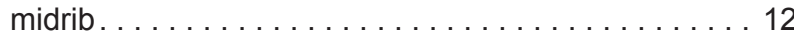

11. Branchlets thinly appressed-pubescent; leaves narrowly oblong, less than $3 \mathrm{~cm}$ broad, thinly appressed-pubescent on midrib and nerves beneath; bracts 2 in each axil, oblong-lanceolate, less than $2 \mathrm{~mm}$ broad, glabrous above, appressed-pubescent hairs on midrib and margin beneath . . . . . . . . . . . . . . . 86. L. oblongatus

11. Branchlets densely brown-hirsute; leaves oblong-elliptic, more than $3 \mathrm{~cm}$ broad, densely hirsute beneath; bracts numerous, lanceolate, more than $2 \mathrm{~mm}$ broad, hirsute. .

.................. 36. L. cyanocarpoides

12. Stipules ovate-triangular, up to $7 \mathrm{~mm}$ long ..........

40. L. ellipticus

12. Stipules not ovate-triangular, relatively small, less than $4 \mathrm{~mm}$ long or inconspicuous . . . . . . . . . 13

13. Bracts linear-lanceolate; drupes glabrous . . . . . . . . . . . . . . . . . . . . . . . . . . 112. L. sikkimensis

13. Bracts filiform or subulate-linear; drupes hairy . . . . 14

14. Bracts filiform, more than $8 \mathrm{~mm}$ long, forming a dense head . . . . . . . . . . . . . . . . . 34itus

14. Bracts subulate-linear, not forming a dense head . . . 15

15. Leaves oblong to oblong-lanceolate, less than $3 \mathrm{~cm}$ broad . . . . . . . . . . . . . . . . . . . . 32. L. coronatus

15. Leaves elliptic-oblong or obovate-elliptic, more than $3 \mathrm{~cm}$ broad . . . . . . . . . . . . . . . . . . . . 16

16. Branchlets spreading tomentose; leaves elliptic, spreading tomentose beneath . . . . . . . . . . 69. L. ledermannii

16. Branchlets subglabrous or appressed-pubescent; leaves obovate-elliptic, appressed-pubescent or subglabrous beneath . . . . . . . . . . . . . . . 13. L. bracteolatus

17. Leaves very large, $22-30$ by $7-12 \mathrm{~cm}$; drupes verrucose, with 6 conspicuous ridges . . . . . . 76. L. megaphyllus

17. Leaves less than $20 \mathrm{~cm}$ long, less than $6 \mathrm{~cm}$ broad; drupes without 6 conspicuous ridges . . . . . . . . 18

18. Leaves thickly coriaceous; bracts 2 , spatulate-obovate, 3 by $2 \mathrm{~mm}$; flowers 4 -merous; drupes $3-4 \ldots \ldots \ldots \ldots$

88. L. obovatibracteatus

18. Leaves coriaceous or chartaceous; bracts more than 2 , not spatulate-obovate; flowers 4-6-merous; drupes 4-5. 19

19. Leaves coriaceous; bracts orbicular or ovate-orbicular 20

19. Leaves chartaceous, membranaceous or subcoriaceous; bracts neither orbicular nor ovate-orbicular . . . . . . . 21

20. Leaves small, ovate-lanceolate, $8-11$ by $1.5 \mathrm{~cm}$ with deeply depressed midrib and nerves above; calyx lobes ovate, longer than the tube ........ 38. L. depressineurus 
20. Leaves relatively large, more than $10 \mathrm{~cm}$ long and more than $2.5 \mathrm{~cm}$ broad; midrib and nerves not depressed above; calyx lobes ovate-lanceolate, not longer than the tube. .

60. L. inodorus

21. Branchlets and leaves glabrous; stipules and bracts glabrous except barbate margins ..... . . 8. L. barbatus

21. Branchlets and leaves hairy beneath; stipules and bracts hairy................... 22

22. Stipules more than $5 \mathrm{~mm}$ long; bracts ovate or ovate-triangular. . . . . . . . . . . . . . . . 23

22. Stipules less than $5 \mathrm{~mm}$ long; bracts linear to linear-lanceolate or lanceolate . . . . . . . . . . . . . . 25

23. Leaves with acute bases; nerves 3-6 pairs; petioles $1.5-2$ $\mathrm{cm}$ long; bracts small, less than $2 \mathrm{~mm}$ long; calyx lobes triangular, $1.5 \mathrm{~mm}$ long, glabrous internal surface; drupes conspicuously 5-8-ridged . . . . . . . 85. L. obliquinervis

23. Leaves with cuneate to obtuse bases; nerves 8-10 pairs; petioles less than $1 \mathrm{~cm}$ long; bracts longer than $2 \mathrm{~mm}$; calyx lobes lanceolate, longer than $1.5 \mathrm{~mm}$, hirsute both surfaces; drupes without conspicuous ridges . . . . . 24

24. Densely spreading tomentose hairs on branches, leaves beneath, stipules, bracts, calyx and drupes . . . . . . . .

89. L. obscurus

24. Thinly appressed-pubescent hairs on branches, leaves beneath, stipules, bracts and calyx; drupes subglabrous . . . . . . . . . . . . . . 23. L. chrysoneurus

25. Stipules triangular; branchlets and leaves beneath appressed-pubescent or puberulous; nervules parallel, bracts lanceolate to subulate; drupes with 4 pyrenes . . . . 26

25. Stipules lanceolate, linear, subulate or inconspicuous; branchlets and leaves beneath hirsute or tomentose; nervules parallel or reticulate; bracts linear, linear-lanceolate or linear-subulate; drupes with 4 or more pyrenes . . 27

26. Branchlets, leaf venation beneath, stipules and bracts appressed-puberulous; drupes glabrous except persistent calyx lobes ............. 50. L. foxworthyanus

26. Branchlets, leaf venation beneath, stipules and bracts very densely appressed-pubescent; drupes puberulous.

80. L. mollis

27 . Leaf base cordate or slightly cordate and more or less oblique; nerves more than 12 pairs; calyx lobes up to 5 $\mathrm{mm}$ long; corolla up to $1.5 \mathrm{~cm}$ long . .... . 97. L. pilosus

27. Leaf base cuneate, acute or subrounded, not oblique; nerves less than 10 pairs; calyx lobes less than $5 \mathrm{~mm}$ long; corolla less than $1.2 \mathrm{~cm}$ long . . . . . . . . . . 28

28. Leaves more than $13 \mathrm{~cm}$ long; bracts numerous; fruits verrucose . . . . . . . . . . . . . . . . . . . . . . 104. L. ridleyi

28. Leaves less than $12 \mathrm{~cm}$ long; bracts not numerous; drupes

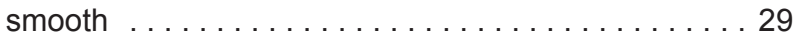

29. Leaves subrounded at base; stipules inconspicuous; bracts linear-lanceolate; pyrenes $8 \ldots \ldots$. . . 4. L. appressus

29. Leaves cuneate or acute at base; stipules linear-subulate or narrowly lanceolate; bracts linear; pyrenes 5-6 . . 30

30. Leaves lanceolate; leaf nervules strongly reticulate; calyx lobes lanceolate, c. $2.5 \mathrm{~mm}$ long ........ . 98. L. politus

30. Leaves oblong or elliptic oblong; leaf nervules parallel; calyx lobes linear, 3-4 mm long . . . 122. L. sylvestroides

31. Peduncles usually more than $4 \mathrm{~cm}$ long $\ldots \ldots \ldots 32$

31. Peduncles usually less than $4 \mathrm{~cm}$ long . . . . . . . . 33

32. Leaves oblong-ovate to ovate; nerves 4-6 pairs; petioles c. $5 \mathrm{~mm}$ long; stipules triangular, less than $2 \mathrm{~mm}$ long ..

46. L. filipedunculatus

32. Leaves oblong; nerves $8-9$ pairs; petioles $2-3 \mathrm{~mm}$; stipules triangular lanceolate, $4-5 \mathrm{~mm}$ long. . . .107. L. robinsonii
33. Peduncles very slender, less than $0.3 \mathrm{~mm}$ diam . . . . 34

33. Peduncles relatively robust, more than $0.3 \mathrm{~mm}$ diam . 35

34. Branchlets appressed hirsute; leaves elliptic-obovate, less than $2.5 \mathrm{~cm}$ long; leaf bases cuneate; stipules very small, inconspicuous; bracts small, subulate or inconspicuous; ovary 4-locular; drupes ovoid with 4 pyrenes . . . . . . . .

11. L. biflorus

34. Branchlets long spreading villose; leaves oblong-lanceolate, more than $5 \mathrm{~cm}$ long; leaf bases rounded to subcordate; stipules linear, c. $4 \mathrm{~mm}$ long; bracts linear to ovate, leaf-like, 6-10 mm long; ovary 8-locular; drupes globose with $6-8$ pyrenes . . . . . . . . . 45. L. filiformis

35. Plant totally glabrous . . . . . . . . . . . . . 36

35. Branchlets and leaf nerves beneath hairy or more or less

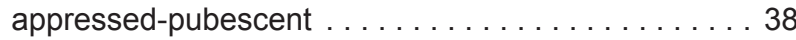

36. Main peduncles up to $3 \mathrm{~cm}$ long, trifurcate; stipules up to $5 \mathrm{~mm}$ long; calyx c. $3 \mathrm{~mm}$ long, with c. $1 \mathrm{~mm}$ long subulate teeth . . . . . . . . . . . . . . . . 68. L. laxiflorus

36. Main peduncles less than $1.5 \mathrm{~cm}$ long, bifurcate; stipules less than $4 \mathrm{~mm}$ long; calyx 8-10 mm long, with 5-6 mm long oblong-lanceolate or lanceolate lobes . . . . . . 37

37. Leaves with looped venation; nerves 4-5 pairs; stipules very small, subulate, less than $1 \mathrm{~mm}$ long; drupes with 4 pyrenes; pyrenes very warty ..... 51. L. furcatoides

37. Leaves without looped venation; nerves 8-10 pairs; stipules triangular, $3 \mathrm{~mm}$ long; drupes with 6 pyrenes; pyrenes smooth . . . . . . . . . . . 64. L. laevigatus

38. Peduncles $2-3.5 \mathrm{~cm}$ long . . . . . . . . . . . . 39

38. Peduncles less than $2 \mathrm{~cm}$ long . . . . . . . . . 41

39. Branchlets, leaves beneath and peduncles sparsely hirsute; leaves chartaceous with acute base; nerves 5-6 pairs; petioles 6-8 $\mathrm{mm}$ long; bracts linear; flowers 4-merous, pediceled . . . . . . . . . . . . . 65. L. lancilobus

39. Branchlets, leaves beneath and peduncles densely spreading villose; leaves coriaceous with subcordate, rounded or obtuse bases; nerves 7-10 pairs; petioles shorter than $6 \mathrm{~mm}$; bracts linear or filiform; flowers 5-merous, sessile . . 40

40. Leaves ovate-lanceolate, with an acuminate apex and a subcordate base; midrib and nerves deeply depressed above; nervules subparallel; petioles c. $1 \mathrm{~mm}$ long; bracts numerous, filiform, up to $1.5 \mathrm{~cm}$ long; corolla glabrous. .

93. L. pendulus

40. Leaves ovate-oblong with a caudate apex and a rounded or obtuse base; nerves flat above, nervules parallel; petioles $5 \mathrm{~mm}$ long; bracts 2, linear, 7-8 mm long; corolla densely villous . . . . . . . . . . . . . . . . . .

41. Bracts 2, ovate, orbicular or cordate, leaf-like, more than $1 \mathrm{~cm}$ broad ................... 42

41. Bracts more than 2 , linear or subulate, not leaf-like, less

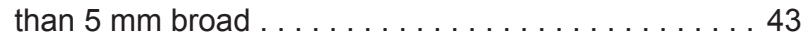

42. Branchlets and leaves densely spreading yellowish hirsute; leaves oblong, with slightly asymmetric base, $10-17$ by $3-5 \mathrm{~cm}$; peduncles $7-8 \mathrm{~mm}$ long, bracts relatively small, c. 1.5 by $1 \mathrm{~cm}$, with shortly cuspidate apex; calyx lobes 5 , 2-3 mm long; pyrenes $5 \ldots \ldots \ldots$. . . . cailinianus

42. Branchlets and leaf nerves, bracts and calyx densely appressed-pubescent; leaves slightly obovate-oblong, 26-34 by $6-8 \mathrm{~cm}$; peduncles c. $2-3 \mathrm{~mm}$ long; bracts large, c. 2 by $2 \mathrm{~cm}$, with a c. $5 \mathrm{~mm}$ long cuspidate apex; calyx lobes 4, $1.5 \mathrm{~mm}$ long; pyrenes 4 . . . . . 24. L. chrysophyllus

43. Leaves $26-46 \mathrm{~cm}$ long; stipules c. $1 \mathrm{~cm}$ long; peduncles very short, 1-2 $\mathrm{mm}$ long; bracts up to $3 \mathrm{~cm}$ long

71. L. longibracteatus

43. Leaves less than $16 \mathrm{~cm}$ long; stipules less than $5 \mathrm{~mm}$ long; peduncles short or long; bracts less than $1.5 \mathrm{~cm}$ long 44 
44. Bracts linear, 6-15 mm long, hirsute; cymes capitate 45

44. Bracts linear or subulate, less than $5 \mathrm{~mm}$ long; hirsute or pubescent; cymes not capitate . . . . . . . . 46

45. Leaf bases subrounded; nerves 9-12 pairs; bracts numerous, usually forming a dense head; peduncles usually very short; calyx lobes linear-lanceolate, c. $3 \mathrm{~mm}$ long; drupes with 5 pyrenes . . . . . . . . . 103. L. rhinocerotis

45. Leaf bases cuneate or acute; nerves 7-8 pairs; bracts not forming a dense head; peduncles up to $1.5 \mathrm{~cm}$ long; calyx lobes subulate-linear, up to $12 \mathrm{~mm}$ long; drupes with 6 pyrenes . . . . . . . . . . . . . 19. L. capitatus

46. Branchlets, leaves beneath and peduncles densely tomen-

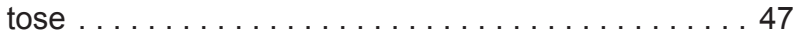

46. Branchlets, leaves beneath and peduncles appressed-pubescent or glabrous . . . . . . . . . . . . 48

47. Peduncles $1-3 \mathrm{~mm}$ long; calyx lobes oblong to lanceolateoblong, $3 \mathrm{~mm}$ long . . . . . . . . 15. L. brevipedunculatus

47. Peduncles longer than $5 \mathrm{~mm}$; calyx lobes linear, $5-6 \mathrm{~mm}$ long . . . . . . . . . . . . 121. L. sumatraensis

48. Leaves linear-lanceolate, less than $2 \mathrm{~cm}$ broad, long-caudate at the apex; calyx lobes triangular, c. $0.8 \mathrm{~mm}$ long . . . . . . . . . . . . . . . . . . . 39. L. dinghouanus

48. Leaves not linear-lanceolate, more than $2.5 \mathrm{~cm}$ broad, acuminate or cuspidate at the apex; calyx lobes ovateoblong or lanceolate, $1.5-4 \mathrm{~mm}$ long . . . . . . . 49

49. Branchlets, leaves beneath and peduncles densely appressed-pubescent; nerves 3-6 pairs; cymes trifurcate; flowers with 3-5 mm long pedicels, 4-merous; calyx lobes lanceolate, c. $1.5 \mathrm{~mm}$ long; drupes with 4 conspicuous ridges; pyrenes $4 \ldots \ldots$. . . . . . 67. L. laxifloroideus

49. Branchlets, leaves beneath and peduncles thinly pubescent or glabrous; nerves 7-8 pairs; cymes bifurcate; flowers sessile, 5-merous; calyx lobes oblong, 3-4 mm long; drupes with 5 ridges; pyrenes $5 \ldots \ldots$ 110. L. scalariformis

Sect. III. Nudiflorae Hook.f. (1880) 184. - Type: Lasianthus blumianus Wight

\section{Key to the species}

1. Cymes very shortly peduncled; branchlets conspicuously sulcate; leaves large, coriaceous, $18-25$ by $5-8 \mathrm{~cm}$; calyx obconic-cupular, truncate or minutely 4 -toothed

95. L. pergamaceus

1. Cymes sessile or tuberculate; branchlets not sulcate; leaves various; calyx various $\ldots \ldots \ldots \ldots \ldots 2$

2. Leaves less than $3 \mathrm{~cm}$ long ........ 10. L. bifloroideus

2. Leaves more than $3 \mathrm{~cm}$ long . . . . . . . . . . 3

3. Leaves linear, $10-14$ by $0.9-1.8 \mathrm{~cm}$, long-caudate at the apex, glabrous . . . . . . . . . . . . . 70. L. linearifolius

3. Leaves otherwise . . . . . . . . . . . . . . 4

4. Leaves with conspicuously looped venation; branchlets and leaves glabrous except sometimes puberulous nerves

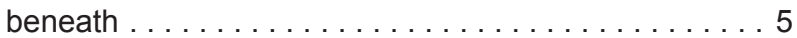

4. Leaves without looped venation; branchlets and leaves glabrous or hairy $\ldots \ldots \ldots \ldots \ldots \ldots \ldots \ldots$

5. Leaves lanceolate, nerves 9-12 pairs; drupes puberulous and slightly warty . . . . . . . . 16. L. brochidodromus

5. Leaves oblong or oblong-lanceolate; nerves less than 9 pairs; drupes glabrous and conspicuously warty. . . . 6

6. Leaves subrounded at the base; nerves 6-8 pairs; drupes with conspicuous 8 ridges; pyrenes with 2 furrows on the abaxial face . . . . . . . . . 77. L. membranaceoideus
6. Leaves acute to cuneate at the base; nerves 3-4 pairs; drupes with 3-4 obtuse ridges; pyrenes without furrow on the abaxial face . . . . . . . . . 63. L. kinabaluensis

7. Flowers on pedicels $2 \mathrm{~mm}$ long or more ........ 8

7. Flowers sessile or subsessile pedicels less than $1 \mathrm{~mm}$

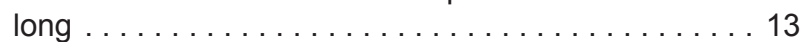

8. Leaves thinly membranaceous; nervules weak, inconspicuous; stipules broadly ovate .. 120. L. submembranifolius

8. Leaves chartaceous to thickly coriaceous; nervules conspicuous; stipules otherwise . . . . . . . . . 9

9. Leaves elliptic, oblong-elliptic or oblong, large, $4.5-8 \mathrm{~cm}$ broad . . . . . . . . . . . . . . . . 10

9. Leaves lanceolate, ovate-lanceolate, oblong-lanceolate, less than $4 \mathrm{~cm}$ broad . . . . . . . . . . . . . . 11

10. Leaves chartaceous or subcoriaceous with acute bases . . . . . . . . . . . . . . . . . 14. L. brevipedicellatus

10. Leaves thickly coriaceous with subrounded bases ..... . . . . . . . . . . . . . . . . . 129. L. vriesianus

11. Leaves; nervules reticulate; pedicels $8-10 \mathrm{~mm}$ long; drupes verrucose, c. $6 \mathrm{~mm}$ diam, with 4 conspicuous obtuse ridges; pyrenes $4 \ldots \ldots \ldots \ldots \ldots \ldots$. . . 101. L. purpureus

11. Leaves; nervules parallel; pedicels $2-3 \mathrm{~mm}$ long; drupes 3-4 mm diam, with 4-5 (smooth) or 7-8 (verrucose) obtuse ridges; pyrenes $4-5$ or $7-8 \ldots \ldots \ldots \ldots \ldots 12$

12. Stipules less than $1 \mathrm{~mm}$ long; calyx with triangular teeth; drupes smooth, with $4-5$ obtuse ridges; pyrenes $4-5$. .

92. L. pedicellatus

12. Stipules 3-4 mm long; calyx truncate; drupes verrucose, with 7-8 obtuse ridges; pyrenes 7-8 . . 87. L. oblongus

13. Leaves narrowly oblong-lanceolate, narrowly lanceolate or linear-lanceolate, $5-6$ times longer than broad, longer than $12 \mathrm{~cm} \ldots \ldots \ldots \ldots \ldots \ldots \ldots \ldots \ldots$

13. Leaves otherwise . . . . . . . . . . . . . . 17

14. Plants densely tomentose; leaves $23-25$ by $3-4 \mathrm{~cm}$; nerves 16-18 pairs; calyx with $7-8$ lanceolate lobes . . . . . . . .

. . . . . . . . . . . . . . . . . . . 41. L. eriocalyx

14. Branchlets glabrous or pubescent; leaves $9-19$ by $1.5-3$ $\mathrm{cm}$; nerves less than 15 pairs; calyx with $4-5$ teeth or with an almost truncate $\operatorname{limb} \ldots \ldots \ldots \ldots \ldots \ldots$

15. Nerves 7 pairs; stipules narrowly triangular, c. $4 \mathrm{~mm}$ long; calyx almost truncate or minutely 5 -toothed

1. L. acuminatissimus

15. Nerves 8-14 pairs; stipules triangular, $2-3 \mathrm{~mm}$ long; calyx with $4-5$ conspicuous teeth $\ldots \ldots \ldots \ldots \ldots 16$

16. Branchlets glabrous; leaves with densely hirsute margin; nerves 8-11; petioles $12-15 \mathrm{~mm}$ long

57. L. hirtimarginatus

16. Branchlets densely appressed-pubescent; leaves without hirsute margin; nerves $12-14$ pairs; petioles $4-5 \mathrm{~mm}$ long 3. L. angustifolius

17. Drupes usually with 2 pyrenes (only in Borneo) . . . . 18

17. Drupes with 3 or more pyrenes . . . . . . . . . 20

18. Leaves membranaceous; drupes ovoid, very rugose, without cork-like structure between pyrenes; pyrenes rugose on the abaxial face ......... 78. L. membranaceus

18. Leaves coriaceous; drupes ellipsoid, smooth, with cork-like structure between pyrenes; pyrenes smooth on the abaxial face $\ldots \ldots \ldots \ldots \ldots \ldots \ldots \ldots \ldots \ldots \ldots \ldots \ldots$

19. Plants glabrous; leaves with subrounded base, nervules conspicuously prominent on both surfaces; petioles 5-7 $\mathrm{mm}$ long; stipules c. $2 \mathrm{~mm}$ long; calyx tube $3 \mathrm{~mm}$ long, not expanded at limb . . . . . . . . . . . . 84. L. nigrescens

19. Branchlets, midrib and nerves beneath and stipules puberulous; leaves with cuneate base; nervules depressed 
or flat above, prominent beneath; petioles 1-1.5 cm long; stipules 4-6 mm long; calyx tube c. $1 \mathrm{~mm}$ long, limb c. 1-1.5 mm long, more or less expanded. .

109. L sabahensis

20. Plants spreading stiffly hirsute; leaves with subrounded and oblique base; nerves 10-12 pairs; stipules narrowly triangular or lanceolate, 4-5 mm long ... 2. L. acutatus

20. Plant otherwise . . . . . . . . . . . . . . . . 21

21. Stipules ovate or ovate-triangular or triangular with a swollen base and a membranaceous margin, 3-6 mm long 22

21. Stipules otherwise . . . . . . . . . . . . . 24

22. Branchlets, leaves, stipules and calyx densely spreading villose; calyx with triangular lobes; drupes villose . . . . . . .

58. L. hirtus

22. Branchlets, leaf midrib and nerves beneath (on lower surface), stipules and calyx thinly puberulous or glabrous; calyx subtruncate, with 4-5 minute teeth at the apex; drupes subglabrous or glabrous . . . . . . . . 23

23. Branchlets, leaf midrib and nerves beneath, stipules and calyx thinly puberulous; leaves with acuminate-caudate apex; nervules obscure above, subparallel; calyx urceolate; drupes with 6-9 pyrenes . . . . . 115. L. stercorarius

23. Branchlets (except the youngest part), leaf midrib and nerves beneath and calyx quite glabrous; leaves with caudate apex; nervules distinct above, parallel; calyx shortly cupular; drupes with 4-5 pyrenes ...130. L. vulcanicus

24. Stipules longer than $6 \mathrm{~mm} \ldots \ldots \ldots \ldots \ldots \ldots \ldots$

24. Stipules shorter than $6 \mathrm{~mm} \ldots \ldots \ldots \ldots \ldots . \ldots 29$

25. Stipules broadly triangular or oblong-ovate, or oblong-lanceolate, coriaceous, glabrous or pubescent, persistent; drupes with sharp ridges . . . . . . . . . . . 26

25. Stipules lanceolate, triangular-lanceolate, linear-lanceolate or subulate, chartaceous, hirsute or strigose, often deciduous; drupes without sharp ridges . . . . . . . . 27

26. Stipules appressed-pubescent; leaves $12-16$ by $3-4.5$ $\mathrm{cm}$; nerves 9-12 pairs; nervules subparallel; petioles 2-3 $\mathrm{mm}$ long; calyx lobes triangular-lanceolate, $1-1.5 \mathrm{~mm}$ long; drupes 8-10-ridged; pyrenes 4-5 . . . 127. L. venosus

26. Stipules glabrous; leaves $20-33$ by $6-11 \mathrm{~cm}$; nerves $13-18$ pairs; nervules reticulate; petioles 5-10 mm long; calyx cupular with minutely teeth at the apex; drupes 6-ridged; pyrenes $6 \ldots \ldots \ldots \ldots \ldots \ldots$ 72. L. longifolius

27. Nervules parallel; calyx lobes 4 ; ovary 4 -locular . . . . . . 125. L. trichophlebus

27. Nervules reticulate to subreticulate; calyx lobes 5 ; ovary 5 -locular . . . . . . . . . . . . . . . . 28

28. Nerves 11 pairs; stipules triangular-lanceolate, $6-7 \mathrm{~mm}$ long, hirsute . . . . . . . . . . 90. L. palawanensis

28. Nerves 6-8 pairs; stipules subulate, $8 \mathrm{~mm}$ long, appressedpubescent .............. 91. L. papuanus

29. Stipules $4-5 \mathrm{~mm} \ldots \ldots \ldots \ldots \ldots \ldots \ldots \ldots \ldots$

29. Stipules shorter than $4 \mathrm{~mm} \ldots \ldots \ldots \ldots \ldots \ldots \ldots 32$

30. Leaves very large, $20-32$ by $6-10 \mathrm{~cm}$; nerves $10-12$ pairs; calyx 7-8 $\mathrm{mm}$ long, lobes oblong, $4-5 \mathrm{~mm}$ long ...... 99. L. pseudolongifolius

30. Leaves less than $20 \mathrm{~cm}$ long; nerves 6-7 pairs; calyx shorter than $5 \mathrm{~mm}$, with minute teeth or lobes triangularsubulate 31

31. Branchlets densely appressed-pubescent; nervules parallel; calyx lobes 5-7, triangular-subulate, as long as the tube; pyrenes $5-7 \ldots \ldots \ldots \ldots$. 114. L. solomonensis

31. Branchlets sparsely spreading hirsute; nervules subreticulate; calyx limb minutely toothed at the apex; pyrenes 4 21. L. chlorocarpus
32. Flowers 4-merous; calyx constricted at the base; drupes ellipsoid or ovoid, very rugose, narrowed at the base; pyrenes $1-4$, deeply furrowed on the abaxial face . . . 33

32. Flowers 4-5-merous; calyx not constricted at base; drupes globose or subglobose, verrucose or smooth, not narrowed at the base; pyrenes 4 or more, not deeply furrowed on the abaxial face . . . . . . . . . . . . . . . . . . 35

33. Branchlets and leaves almost glabrous; leaves chartaceous to subcoriaceous; cymes conspicuously tuberculate (short congested peduncles, up to $5 \mathrm{~mm}$ long); calyx with 4 triangular lobes; the lobes c. $1 \mathrm{~mm}$ long; corolla tube slender, more than $5 \mathrm{~mm}$ long . . . . . . . 27. L. congesticymus

33. Branchlets and leaf nerves beneath more or less appressed puberulous, pubescent or strigose; leaves coriaceous; cymes sessile or shortly tuberculate; calyx truncate or minutely toothed or with minutely triangular lobes; corolla tube stout, less than $3 \mathrm{~mm}$ long . . . . . . . . . 34

34. Branchlets thinly puberulous or sparsely strigose; leaves $8-13$ by $3-4 \mathrm{~cm}$; nervules $3-6$ pairs; petioles $4-5 \mathrm{~mm}$ long; cymes sessile; calyx truncate or minutely toothed .

29. L. constrictus

34. Branchlets densely appressed-pubescent; leaves 19-26 by $6-9 \mathrm{~cm}$; nerves $6-7$ pairs; petioles $5-10$; cymes shortly tuberculate; calyx with 4 minutely triangular lobes

102. L. reticulatus

35. Calyx with a cupular limb, truncate or minutely toothed at the apex .................... 36

35. Calyx with conspicuously lobes . . . . . . . . 39

36. Leaves $18-30 \mathrm{~cm}$ long ........... 7. L. baasianus

36. Leaves less than $18 \mathrm{~cm}$ long . . . . . . . . . . . 37

37. Plant glabrous; leaves chartaceous; petioles c. 2.5-3.5 $\mathrm{mm}$ long; drupes without an enlarged cupular calyx ....

28. L. conspicuus

37. Branchlets and leaf venation beneath pubescent or puberulous; leaves coriaceous; petioles longer that $5 \mathrm{~mm}$, drupes with an enlarged cupular calyx . . . . . . 38

38. Leaves with conspicuously reticulate nervules; nerves 10 12 pairs; petioles $10-15 \mathrm{~mm}$ long; drupes 5-6-ridged . .

118. L. subaureus

38. Leaves with parallel nervules; nerves 5-9; petioles 5-10 mm long; drupes without ridges . ... 128. L. verticillatus

39. Calyx divided to the base, or calyx lobes conspicuously longer than the calyx tube . . . . . . . . . . 40

39. Calyx not cleft to the base, calyx lobes shorter than the calyx tube or just as long as the calyx tube . . . . 4 48

40. Calyx lobes oblong, obtuse at the apex 12. L. borneensis

40. Calyx lobes lanceolate or lanceolate-triangular, acuminate or acute at the apex

41

41. Leaves large, more than $12 \mathrm{~cm}$ long ... . 66. L. latifolius

41. Leaves relatively small, usually less than $12 \mathrm{~cm}$ long

42. Leaves glabrous or glabrous except appressed-hirsute or sparsely hirsute midrib and nerves and/or margin beneath; branchlets glabrous or sparsely hirsute or more or less appressed-hirsute; calyx lobes narrowly lanceolate with a long-acuminate apex or oblong; drupes glabrous or sparsely hirsute. . . . . . . . . . . . . . . . . 43

42. Leaves very hairy beneath; branchlets very hairy but not appressed-hirsute; calyx lobes broadly lanceolate, usually acute at the apex; drupes hairy . . . . . . . . . 45

43. Leaves ovate or ovate-elliptic, usually caudate at the apex; nervules parallel; flowers 5-merous; calyx lobes narrowly lanceolate with a long acuminate apex; drupes smooth, without ridges; pyrenes $5 \ldots \ldots \ldots$. . . . . L. lucidus 
43. Leaves otherwise in shape; nervules reticulate; flowers 4-merous; calyx lobes lanceolate or oblong; drupes with 4 obtuse ridges; pyrenes $4 \ldots \ldots \ldots \ldots \ldots 4$

44. Leaves oblong-lanceolate to lanceolate, $1.2-1.5 \mathrm{~cm}$ broad, without a marginal vein; nerves 7-9 pairs; stipules subulate-triangular, c. $1 \mathrm{~mm}$ long; bracts 2 , subulate, 2-3 $\mathrm{mm}$ long, spreading hirsute; calyx $2 \mathrm{~mm}$ long, sparsely spreading hirsute; calyx lobes lanceolate, $1.2 \mathrm{~mm}$ long; drupes globose, smooth on the external surface

105. L. ridsdalei

44. Leaves ovate-elliptic, $2-3.5 \mathrm{~cm}$ broad, with an obscure marginal vein; nerves $4-5$ pairs; stipules very small, triangular, c. $0.5 \mathrm{~mm}$ long; bracts absent; calyx c. $4.5 \mathrm{~mm}$ long, puberulous; calyx lobes oblong, $3 \mathrm{~mm}$ long; drupes subglobose, verrucose on the external surface

\section{L. floresensis}

45. Leaves ovate-oblong, ovate-elliptic or ovate-lanceolate usually cuspidate at the apex; midrib glabrous above; flowers 5-merous; drupes with 5 pyrenes . . . . . . 46

45. Leaves usually lanceolate, acute or acuminate at the apex; midrib hairy above; flowers 4-merous; drupes with 4 pyrenes $\ldots \ldots \ldots \ldots \ldots \ldots \ldots \ldots \ldots \ldots 47$

46. Branchlets densely tomentose; leaves ovate-oblong to oblong, tomentose beneath; nervules parallel; stipules triangular, 2-3 mm long; calyx not divided to the base; calyx tube c. $1 \mathrm{~mm}$ long; calyx lobes 1.5-2 mm long; drupes tomentose . . . . . . . . . . . . . . . 124. L. tomentosus

46. Branchlets densely spreading villose; leaves elliptic-lanceolate or ovate-lanceolate, softly villose beneath; nervules subparallel; stipules inconspicuous; calyx divided to the base; calyx lobes up to $5 \mathrm{~mm}$ long; drupes hirsute

. . . . . . . . . . . . . . . . . 35. L. curtisii

47. Branchlets relatively slender, densely appressed-hirsute; leaves beneath and midrib above densely appressedpubescent; bracts absent ........ 54. L. hexandrus

47. Branchlets relatively robust, densely and coarsely spreading hirsute; leaves beneath and midrib above densely and coarsely spreading hirsute; bracts linear, 3-6 mm long .

25. L. chrysotrichus

48. Branchlets and leaves glabrous and darkish when dry; leave subrounded or rounded, thickly coriaceous, $3-6$ by $2-4.5$ $\mathrm{cm}$, rounded or subcordate at the base; venation very distinct on both surfaces; nerves 5 pairs; flowers 4-merous; calyx campanulate with 4 broadly triangular teeth; drupes with 4 pyrenes (only in Borneo) . . . . . 108. L. rotundatus

48. Plant otherwise . . . . . . . . . . . . . . . 49

49. Branchlets and leaves spreading villose; leaves linearoblong, thinly chartaceous; drupes oblate-globose, glabrous, smooth, with 7-8 obtuse ridges; pyrenes 7-8 . .

\section{L. tenuifolius}

49. Branchlets, leaves and drupes otherwise . . . . . . 50

50 . Leaves with conspicuously reticulate or subreticulate nervules . . . . . . . . . . . . . . . 51

50. Leaves with parallel or subparallel nervules . . . . . 64

51 . Leaves lanceolate, $12-14$ by $2.5-3 \mathrm{~cm}$, caudate-acuminate at the apex; nerves 10-11 pairs; stipules broadly triangular, 3-4 mm, black and glabrous; calyx campanulate, 2-2.5 $\mathrm{mm}$ long, glabrous external surface, long yellowish hairy internal side, minutely 5-6-toothed at the apex; drupes globose, verrucose; pyrenes 5-6 . . . 62. L. iteophyllus

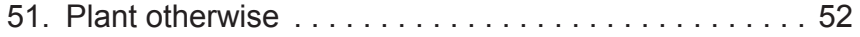

52. Branchlets and leaves beneath glabrous or thinly puberulous; leaves linear-lanceolate, with rounded and asymmetric base, $8-14$ by $1.5-3 \mathrm{~cm}$; petioles $1 \mathrm{~cm}$ long; stipules very small, triangular, c. $1 \mathrm{~mm}$ long; calyx limb with 5 subulate-triangular, c. $0.5 \mathrm{~mm}$ long teeth; drupes without ridges; pyrenes $4 \ldots \ldots \ldots \ldots \ldots$. . . . . L. bruneensis

52. Plant otherwise $\ldots \ldots \ldots \ldots \ldots \ldots \ldots \ldots \ldots$

53. Branchlets glabrous or subglabrous; leaves thickly coriaceous, glabrous or subglabrous; drupes with 8 ridges 54

53. Branchlets more or less hairy; leaves chartaceous to subcoriaceous, more or less hairy on venation beneath; drupes with 4-6 ridges or without conspicuous ridges . . . . 5 55

54. Leaves lanceolate, $12-19 \mathrm{~cm}$ long; stipules subulate, c. 2 $\mathrm{mm}$ long, puberulous; calyx densely puberulous; calyx lobes ovate, c. $1 \mathrm{~mm}$ long; drupes puberulous

5. L. atroneurus

54. Leaves lanceolate-oblong or oblong, 9-11 cm long; stipules triangular, c. $3 \mathrm{~mm}$ long, glabrous; calyx glabrous or sparsely puberulous; calyx lobes ovate-oblong, c. $2 \mathrm{~mm}$ long; drupes glabrous ......... 31. L. coriaceifolius

55. Branchlets, leaves both surfaces, stipules and calyx densely dark-brown hispid; leaves subrounded and slightly asymmetric at the base; calyx lobes 5 , ovate-triangular, 1.5 by $1.5 \mathrm{~mm}$, as long as the calyx tube 111 . L. setulosus

55. Plant otherwise . . . . . . . . . . . . 56

56 . Leaves relatively large, longer than $15 \mathrm{~cm}$, broader than $4 \mathrm{~cm}$; petioles longer than $1 \mathrm{~cm}$; calyx $5-7 \mathrm{~mm}$ long, with 4-6 triangular-ovate to orbicular reflexed lobes; drupes with $5-6$ ridges . . . . . . . . . . 20. Linensis

56. Leaves less than $15 \mathrm{~cm}$ long and $4 \mathrm{~cm}$ broad; petioles less than $1 \mathrm{~cm}$ long; calyx less than $5 \mathrm{~mm}$ long; calyx lobes otherwise; drupes without ridges . . . . . . . . . 57

57. Nerves more than 10 pairs; petioles $2-5 \mathrm{~mm}$ long . . . 58

57. Nerves less than 10 pairs; petioles $5-8 \mathrm{~mm}$ long . . . 61

58. Branchlets and petioles appressed-pubescent or puberulous; calyx with minute teeth . . . . . 81. L. mucronulatus

58. Branchlets and petioles densely brownish tomentose; calyx with conspicuously lobes . . . . . . . . . . . . . 59

59. Leaves longer than $12 \mathrm{~cm}$; nerves $14-18$ pairs; petioles 5 $\mathrm{mm}$ long; drupes densely brownish tomentose .

44. L. ferrugineus

59. Leaves shorter than $12 \mathrm{~cm}$; nerves 10-13 pairs; petioles c. $2 \mathrm{~mm}$ long; drupes pubescent or glabrous . . . . . 60

60 . Leaves rugose, puberulous both surfaces or only beneath, acute or caudate-cuspidate at the apex, undulate at margin; reticulate nervules obscure above; stipules subulatetriangular, densely tomentose; calyx with an obconic tube and a shortly campanulate limb .... 126. L. undulatus

60. Leaves smooth, tomentose on midrib and nerves both surfaces, acuminate at the apex, not undulate at the margin; reticulate nervules conspicuous above; stipules broadly triangular, glabrous; calyx otherwise . 131. L. wightianus

61. Stipules 1.5-3 mm long; pyrenes 6 119. L. subglobosus

61. Stipules less than $1.5 \mathrm{~mm}$ long; pyrenes $4-5 \ldots \ldots 62$

62 . Nerves 5 pairs; calyx campanulate; calyx lobes ovatetriangular, 1.5-2 mm long ... . . . 55. L. hirsutisepalus

62. Nerves more than 6 pairs; calyx obconical or campanulatecupular; calyx lobes triangular, $1 \mathrm{~mm}$ long or calyx minutely 5-toothed . . . . . . . . . . . . . . . . . . 63

63. Branchlets densely appressed-hirsute; leaves villose beneath; midrib depressed and hirsute above; petioles densely appressed-hirsute; stipules $1 \mathrm{~mm}$ long, appressed-hirsute; calyx obconic, densely villose; calyx lobes triangular, $1 \mathrm{~mm}$ long, villose both surfaces; drupes villose . 61. L. iteoides

63. Young branchlets puberulous, later glabrescent; leaves appressed-pubescent on midrib and nerves beneath; midrib slightly prominent and glabrous above; petioles subglabrous; stipules c. $1.5 \mathrm{~mm}$ long, puberulous; calyx cam- 
panulate-cupular, puberulous, minutely 5 -toothed; drupes glabrous ............... . 74. L. malaccensis

64. Branchlets and leaves glabrous; leaves lanceolate, ovatelanceolate to ovate-elliptic, cymes subsessile or shortly tuberculate; flowers extremely small; calyx c. $1 \mathrm{~mm}$ long

64. Plant otherwise . . . . . . . . . . . . 66

65 . Leaves $8-12$ by $2-3.5 \mathrm{~cm}$; nerves $4-5$ pairs; calyx glabrous or sparsely puberulous; drupes oblate-globose, strongly warty; pyrenes with irregular sharp ridges

96. L. phymatodeus

65. Leaves $15-28$ by $3.5-5 \mathrm{~cm}$; nerves $7-10$ pairs; calyx densely hirsute; drupes globose, smooth; pyrenes smooth on the abaxial face . . . . . . . . . . . . 79. L. minutiflorus

66. Branchlets and leaf venation beneath densely appressedpubescent; leaf midrib depressed above and strongly elevated beneath; calyx cupular-campanulate, 3-4 mm long; calyx lobes 5, ovate-triangular, curved inward, 1-1.5 $\mathrm{mm}$ long; drupes conspicuously $4-5$-ridged . . . . . . . . 47. L. flavinervius

66. Plant otherwise . . . . . . . . . . . . . . . . . . . . 67

67. Leaves relatively large, more than $5 \mathrm{~cm}$ broad; drupes $10-12$ ridged . . . . . . . . . . . . 94. L. perakensis

67. Leaves relatively small, less than $5 \mathrm{~cm}$ broad; drupes with obtuse 4 ridges or smooth . . . . . . . . . 68

68. Leaves less than $7.5 \mathrm{~cm}$ long, coriaceous; flowers 4-merous; drupes with 4 pyrenes . . . . . . . . . . . . . 69

68. Plant otherwise . . . . . . . . . . . . . . . 70

69. Branchlets, leaf midrib and nerves beneath and petioles tomentose, calyx densely tomentose; drupes without ridges 83. L. nervosus

69. Branchlets, leaf midrib and nerves and petioles glabrous or thinly puberulous; calyx pubescent; drupes with 4 ridges 82. L. myrtifolius

70. Branchlets sparsely appressed-hirsute to glabrous; leaves coriaceous, oblong-lanceolate, $8-13$ by $2.5-3.5 \mathrm{~cm}$, glabrous or sparsely hirsute on nerves beneath; nerves 6-9; nervules subparallel; stipules triangular, 3-4 mm long, coriaceous; calyx lobes 4 , triangular, c. $2 \mathrm{~mm}$ long; drupes with 5 pyrenes . . . . . . . . . 116. L. sterrophyllus

70. Plant otherwise . . . . . . . . . . . . . . 71

71. Branchlets, leaves beneath, petioles, stipules and calyx densely brown-tomentose; leaves lanceolate or oblonglanceolate, $9-15$ by $2-3.5 \mathrm{~cm}$; nerves $6-8$ pairs; nervules parallel; petioles c. $1 \mathrm{~cm}$ long; stipules c. $2 \mathrm{~mm}$ long; calyx tube c. $1 \mathrm{~mm}$ long, the lobes triangular; drupes smooth, sparsely tomentose, with 4-5 pyrenes . . 22. L. chryseus

71. Plant otherwise . . . . . . . . . . . . . . 72

72. Branchlets and leaf midrib and nerves beneath densely appressed-pubescent; leaves elliptic or oblong-elliptic, $5-10$ by $1.5-4 \mathrm{~cm}$, coriaceous; nerves $7-8$ pairs; nervules densely anastomosing, parallel, distinct on both surfaces; stipules c. $1 \mathrm{~mm}$ long; flowers 4-merous; calyx limb dish-like, truncate or minutely 4-toothed; drupes with 4 pyrenes . .

42. L. euneurus

72. Plant otherwise . . . . . . . . . . . . . . . 73

73. Leaves oblong, $10-15 \mathrm{~cm}$ long; nerves $9-11$ pairs; petioles $1-1.5 \mathrm{~mm}$ long; calyx 3-4 mm long; calyx lobes triangular, 1-1.5 mm long . . . . . . . . . . . 43. L. fasciculus

73. Leaves elliptic, ovate-oblong less than $10 \mathrm{~cm}$ long; nerves 4-6 pairs; petioles shorter than $1 \mathrm{~cm}$; calyx less than 3 $\mathrm{mm}$ long; calyx teeth less $1 \mathrm{~mm}$ long $\ldots \ldots \ldots \ldots 74$

74. Branches and leaf nerves beneath glabrous or sparsely pubescent; calyx sparsely pubescent; drupes glabrous .

$\ldots \ldots \ldots \ldots \ldots \ldots \ldots \ldots$. . . . . . . fordii
74. Branches and leaves beneath densely villose or pubescent; calyx densely villous or pubescent; drupes pubescent or hirsute . . . . . . . . . . . . . . . . 75

75. Branches, leaves beneath and calyx densely spreading villose; drupes hirsute . . . . . . . . . 59. L. hispidulus

75. Branches, leaves beneath and calyx more or less appressed-pubescent; drupes appressed-pubescent . . . . .

26. L. clementis

\section{Lasianthus acuminatissimus Merr.}

Lasianthus acuminatissimus Merr. (1922) 467; (1923) 565. - Lectotype (designated here): Bur. Sci. 38058 (Ramos \& Edaňo) (lecto K; isolecto P, US), Philippines, Luzon, Bontoc, Mt Caua, 1800 m.

Shrubs, c. $1 \mathrm{~m}$ high; branchlets terete, 2-3 mm diam, brown, minutely appressed-pubescent. Leaves: blades narrowly lanceolate, $9-19$ by $1.5-3 \mathrm{~cm}$, chartaceous, glabrous above, puberulous beneath, apex caudate-acuminate, base acute, midrib slightly depressed above, prominent and appressed-pubescent beneath, nerves flat above, prominent and appressed-pubescent beneath, 7 pairs, ascending at an angle of $45-50^{\circ}$, nervules distinct on both surfaces, puberulous beneath, subreticulate; petioles 5-7 mm long, appressed-pubescent. Stipules narrowly triangular to linear-lanceolate with an acuminate apex, c. $4 \mathrm{~mm}$ long. Inflorescences sessile; bracts absent. Flowers sessile, fascicled; calyx $2.5-3 \mathrm{~mm}$ long, slightly puberulous; calyx limb cupular with 5 minute teeth; corolla tube cylindrical, c. $5 \mathrm{~mm}$ long, pubescent outside, glabrous inside in the lower half, villous in the upper half; corolla lobes $3 \mathrm{~mm}$ long, oblong, villous inside; anthers oblong, c. $2.2 \mathrm{~mm}$ long; style $6 \mathrm{~mm}$ long; ovary 5-locular. Fruits unknown.

Distribution - Endemic to the Philippines.

Note - This species is highly similar to L. morus Elmer in absence of assessment of relationships. It has similar calyx, stipules and indumentums to the latter, but differs in having narrowly lanceolate and chartaceous leaf blades with an elongated caudate-acuminate apex, and subreticulate nervules. Only the type specimen is known.

\section{Lasianthus acutatus Miq.}

Lasianthus acutatus Miq. (1861) 549. — Type: Teysmann s.n., HB4011 (holo U), Sumatra, Moeara Enim, Palembang.

Shrubs; branchlets terete, spreading hirsute, brown. Leaves: blades oblong-lanceolate, $12-15$ by $3-4 \mathrm{~cm}$, subcoriaceous, spreading hirsute hairs on both surfaces, denser beneath and no midrib, apex acute to shortly caudate, base subrounded and oblique, midrib and nerves slightly depressed above, prominent beneath, nerves ascending at an angle of c. $50^{\circ}$, curved to the margin, 10-12 pairs, nervules obscure above, distinct beneath, subparallel; petioles c. $5 \mathrm{~mm}$ long, densely spreading hirsute. Stipules triangular-lanceolate to lanceolate, 4-5 mm long, spreading hirsute. Cymes sessile; bracts absent. Flowers sessile. Drupes crowned by 5 lanceolate calyx lobes, hirsute; pyrenes 5.

Distribution - Endemic to Sumatra.

Note - Miquel (1869) sank this species to L. mucronulatus. However, it differs from $L$. mucronulatus in having spreading stiff hairs on branches, leaves and stipules, and triangular-lanceolate to lanceolate stipules which are $4-5 \mathrm{~mm}$ long. Lasianthus mucronulatus has appressed-pubescence on branches, leaf nerves beneath and stipules, and small triangular stipules. Lasianthus acutatus differs from $L$. stercorarius in having spreading stiff hairs on branches, leaves and stipules too, and triangular-lanceolate to lanceolate stipules without a swollen base. Lasianthus acutatus is probably a rare species, and is known only from the type specimen. 


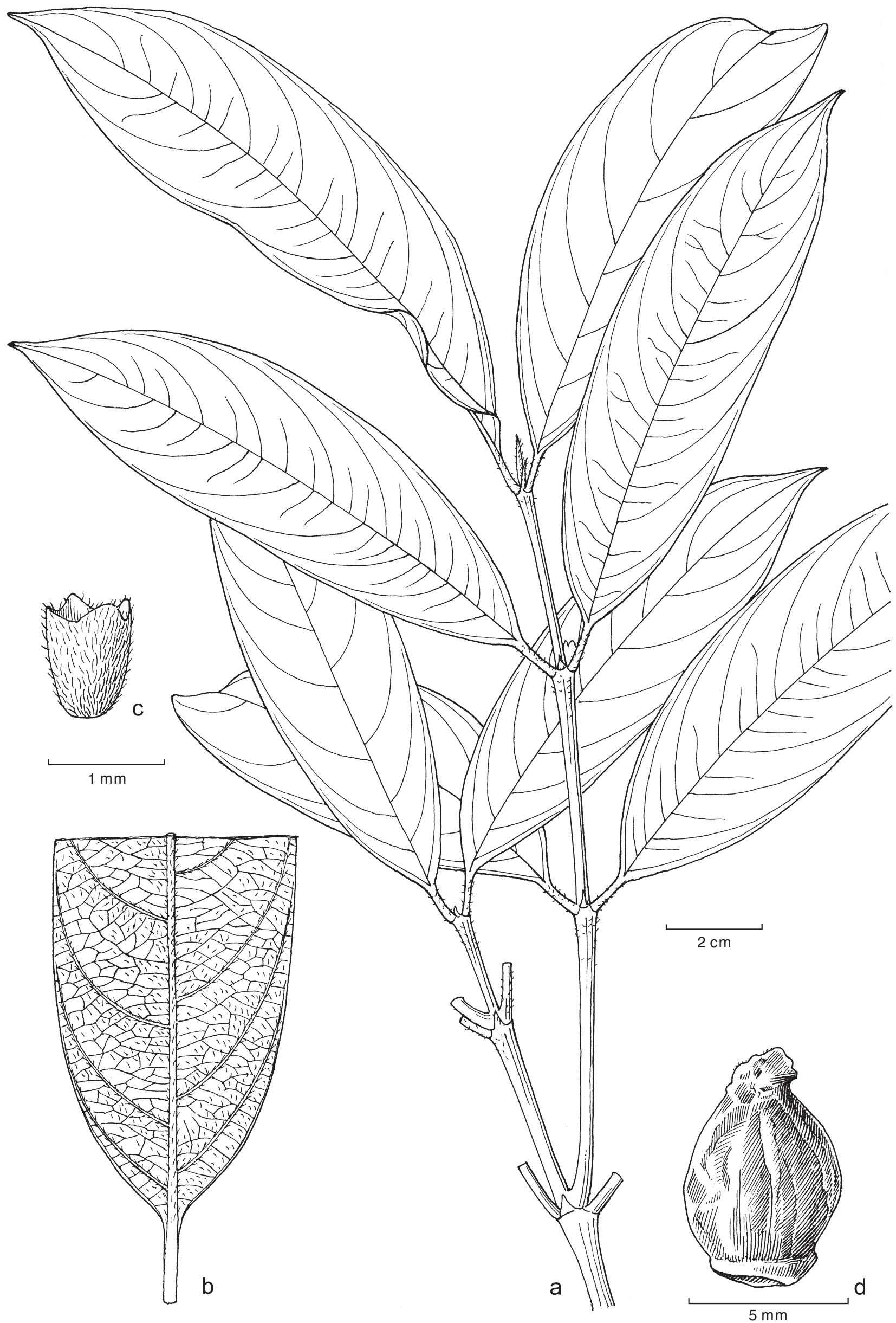

Fig. 1 Lasianthus atroneurus H.Zhu. a. Habit with inflorescences; b. lower surface of leaf showing reticulate nervules; c. calyx; d. fruit (all: Van Balgooy \& Van Stetten 5396, holo L). 


\section{Lasianthus angustifolius King \& Gamble}

Lasianthus angustifolius King \& Gamble (1904)126; Ridl. (1923a) 161; K.M.Wong (1989) 368. - Type: Wray 413 (holo n.v.; iso L), Peninsular Malaysia, Perak, $4500 \mathrm{ft}$.

Lasianthus salicifolius Ridl. (1909) 35; (1923a) 166; K.M.Wong (1989) 367, syn. nov. - Type: Ridley 14008 (holo SING), Peninsular Malaysia, Pahang, $5000 \mathrm{ft}$.

Small trees, up to $4.5 \mathrm{~m}$ high; branchlets terete, c. $2 \mathrm{~mm}$ diam, densely appressed-pubescent. Leaves: blades narrowly oblong-lanceolate or lanceolate, $12-15$ by $1.5-2 \mathrm{~cm}$, chartaceous to subcoriaceous, glabrous above except densely tomentose midrib, glabrous beneath except appressed-pubescent midrib and nerves, apex long-caudate to caudate-acuminate, base cuneate, midrib and nerves flat above, prominent beneath, nerves $12-14$ pairs, ascending at an angle of c. $50^{\circ}$, curved to the margin, nervules faint on the upper surface, distinct on the lower surface, reticulate; petioles 4-5 mm long, hirsute. Stipules triangular to triangular-lanceolate, 2-3 mm long, glabrous except ciliate margins. Cymes sessile; bracts absent. Flowers sessile; calyx tubular-campanulate, c. $2 \mathrm{~mm}$ long, appressedpubescent on both sides, with 5 triangular-acuminate teeth, calyx teeth c. $0.5 \mathrm{~mm}$ long; corolla tubular, $5 \mathrm{~mm}$ long, tube glabrous on both sides; lobes 5 , triangular-lanceolate, c. 1.5 $\mathrm{mm}$ long, appressed-pubescent on both sides; anthers narrowly oblong. Drupes ovoid-globose, c. $4 \mathrm{~mm}$ diam, sparsely pubescent, with 4-5 obtuse ridges; pyrenes 4-5, abaxially rugose.

Distribution - Peninsular Malaysia.

Note - Lasianthus angustifolius is close to L. hirtimarginatus, but differs from the latter in having densely appressedpubescent branchlets, narrowly lanceolate to linear-lanceolate leaves with densely pubescent midrib above and 12-14 pairs of nerves, petioles $4-5 \mathrm{~mm}$ long.

\section{Lasianthus appressus Hook.f.}

Lasianthus appressus Hook. (1880) 181; King \& Gamble (1904) 121; Ridl. (1923a) 156; Craib (1934) 207; K.M.Wong (1989) 371; H.Zhu (2001b) 122. - Type: Griffith 2927 (lecto K, designated here), Peninsular Malaysia.

Shrubs, c. $1.5 \mathrm{~m}$ high; branches and branchlets terete, densely appressed-hirsute. Leaves: blades relatively small, lanceolate, $6-8$ by $2-2.5 \mathrm{~cm}$, subcoriaceous, pale shining and glabrous above when dry except the hairy midrib, hirsute on midrib and nerves as well as nervules beneath, apex acute to acuminate, base acute to cuneate, midrib and nerves slightly depressed above, prominent beneath, nerves $6-8$ pairs, ascending at an angle of $35-40^{\circ}$, curved to the margin, nervules obscure above, prominent beneath, subparallel; petioles $4-5 \mathrm{~mm}$ long hirsute. Stipules very small, inconspicuous. Cymes sessile; bracts linearlanceolate to subulate, up to $5 \mathrm{~mm}$ long, dense hirsute. Flowers sessile; calyx campanulate, pubescent outside, calyx tube c. $1 \mathrm{~mm}$ long, calyx lobes 4, triangular, $1 \mathrm{~mm}$ long; corolla tube $5 \mathrm{~mm}$ long, pubescent in upper part outside, corolla lobes 4 , lanceolate, $2 \mathrm{~mm}$ long, pubescent both sides. Drupes small, 2-3 $\mathrm{mm}$ diam, subglobose, crowned by the triangular hirsute calyx-teeth, glabrous; pyrenes 8 .

Distribution - Thailand, Peninsular Malaysia, Singapore.

\section{Lasianthus atroneurus H.Zhu, sp. nov. - Fig. 1}

Similis $L$. chinensis Benth., sed foliis crasse coriaceis, lobis calycis 4 , pyrenis 4 differt. Similis to L. pergamaceus King \& Gamble, sed cymis sessilis, foliis lanceolatis, lobis calycis ovatis differt. - Typus: Van Balgooy \& Van Setten 5396 (holo L), Borneo, W Kalimantan, Gunung Palung, 1000 m alt., in montane forest of summit ridge on granite, 12 June 1986.

Treelet, $3 \mathrm{~m}$ high; branchlets robust, c. $3 \mathrm{~mm}$ diam, compressed, fistulous, subglabrous, dark brown in the youngest part. Leaves: blades lanceolate, $12-19$ by $3.5-4.3 \mathrm{~cm}$, thickly coriaceous, glabrous above, puberulous to glabrescent beneath, apex acute, the base cuneate midrib flat to slightly prominent above, strongly prominent beneath, dark brown and puberulous or glabrescent beneath, nerves slightly prominent above, strongly prominent beneath, $7-8$ pairs, ascending at an angle of $70-80^{\circ}$, curved to margin, dark brown and puberulous or glabrescent beneath, nervules conspicuously prominent on both surfaces, reticulate, puberulous or glabrescent beneath, margin conspicuously recurved; petioles $5-10 \mathrm{~mm}$ long, puberulous and dark in colour. Stipules subulate, c. $2 \mathrm{~mm}$ long, puberulous. Inflorescences axillary, sessile; bracts inconspicuous. Flowers sessile; calyx tubular-cupular, c. $4 \mathrm{~mm}$ long, densely puberulous external surface, calyx lobes 4 , ovate, c. $1 \mathrm{~mm}$ long, slightly folded; corolla not seen. Drupes ellipsoid, c. $5 \mathrm{~mm}$ diam, puberulous, with 8 ridges (alternately 4 obtuse and 4 acute), crowned by persistent shortly cupular calyx limbs with ovate lobes; pyrenes 4.

Distribution - Endemic to Borneo (Kalimantan).

Habitat \& Ecology - In montane forests on ridge top on granite soil at c. $1000 \mathrm{~m}$ altitude. Fruiting between March and June.

Additional specimen examined. Kalimantan, Gunung Palung, 1¹2'S, $110^{\circ} 8$ 'E, $1000 \mathrm{~m}$ alt., T.G. Laman et al. TL801 (K, L).

Note - This species has conspicuously reticulate nervules and a tubular calyx with slightly folded ovate lobes, which points to relationship with $L$. chinensis, but differs from the latter in having thickly coriaceous leaves, calyx with 4 lobes and drupes with 4 pyrenes. It is similar to L. pergamaceus, but differs in having sessile cymes, lanceolate leaves and ovate calyx lobes, while $L$. pergamaceus has shortly peduncled cymes, oblongelliptic leaves and truncate calyx limbs.

\section{Lasianthus attenuatus Jack}

\section{Key to the varieties}

1. Leaves oblong, more than $2 \mathrm{~cm}$ broad; stipules triangular or ovate-lanceolate, $2-3 \mathrm{~mm}$ long; bracts 6-15 mm long; corolla $10-12 \mathrm{~mm}$ long . . . . . . . . . a. var. attenuatus

1. Leaves linear-oblong, less than $2 \mathrm{~cm}$ broad; stipules triangular-lanceolate, $5-8 \mathrm{~mm}$ long; bracts $5 \mathrm{~mm}$ long; corolla $8 \mathrm{~mm}$ long . . . . . m. ma $\ldots \ldots \ldots$ b. var. mo

\section{a. var. attenuatus - Map 2}

Lasianthus attenuatus Jack (1823) 126; Valeton (1927) 107; Merr. (1952) 229; Bakh.f. (1965) 338; K.M.Wong (1989) 367, p.p.; H.Zhu (2002) 72. Mephitidia attenuata (Jack) DC. (1830) 452; Korth. (1851) 219. - Type: Jack s.n. (holo n.t.; iso L, barcode L0000674), Sumatra (Bencoolen).

Nonatelia? hispida Wall. ex Roxb. (1824) 187. - Mephitidia wallichii Wight \& Arn. (1834) 390, in nota, nom. superfl. - Lasianthus wallichii (Wight \& Arn.) Wight (1846) 503; Hook.f. (1880) 180; Matsum. (1901) 16; Prain (1903) 576; Pit. (1924) 387; Craib (1934) 220; Hara \& Gould (1979) 204; Wu (1984) 1259; Deb \& M.Gangop. (1991) 307; H.Zhu (1994) 56; (1998) 157; H.J.Li \& H.Y.Liu (1998) 295, pl. 133; H.S.Lo (1999) 73, pl. 18: 1-7; H.Zhu (2001b) 146, nom. superfl. — Type: De Silva s.n. ex Wall. Cat. 8442 (holo K), India, Silhet.

Mephitidia attenuata Jack var. glabra Korth. (1851) 220. - Type: Korthals (n.v.), Sumatra, Singalang.

Lasianthus densifolius Miq. (1857) 321; Craib (1934) 210; K.M.Wong (1989) 368, p.p. - Lectotype (here designated): Junghuhn s.n. (lecto L, barcode L0000679), Java, Ungaran.

Lasianthus plagiophyllus Hance (1875) 196; T.S.Liu \& J.M.Chao (1964) 147 f. 16. - Mephitidia plagiophylla (Hance) Nakai (1927) 529. — Lasianthus wallichii (Wight \& Arn.) Wight subsp. plagiophyllus (Hance) Wu \& H.Zhu in Zhu (1994) 57. - Type: Hance 18438 (holo BM, iso K), China, Hongkong. Lasianthus densifolius Miq. var. calycinus King \& Gamble (1904) 122; Ridl. (1923a) 153. - Type: Ridley 5679 (n.v.), Singapore.

Lasianthus densifolius Miq. var. latifolia King \& Gamble (1904) 122; Ridl. (1923a) 153. - Type: Ridley 10948 (lecto SING, designated by Wong 1989; isolecto K), Peninsular Malaysia, Johore. 
Lasianthus brachyphyllus K.Schum. (1905) 399; Valeton (1927) 106, syn. nov. - Type: Nyman n.678 (n.v.), New Guinea.

Lasianthus copelandi Elmer (1906b) 10; Merr. (1907) 306; Elmer (1913) 1869; Merr. (1923) 566, syn. nov. - Type: E.B. Copeland s.n. (n.v.), Philippines, Negros.

Lasianthus bordeni Elmer (1906b) 11. — Type: Elmer 6977 (iso E, K), Philippines, Luzon, Bataan.

Lasianthus tonkinensis (Drake) Pit. (1924) 376. - Mephitidia tonkinensis Drake (1895) 240. - Type: Balansa 2656 (holo P; iso K), Tonkin, Bavi. Lasianthus attenuatus Jack var. subsessilis Valeton (1927) 108, syn. nov. - Type: Schlechter 17334 (holo B†), New Guinea.

Shrubs, 1-2 m tall; branches and branchlets usually densely tomentose or sometimes setose. Leaves: blades oblong, ellipticlanceolate or oblong-ovate, $5-12$ by $2.5-5 \mathrm{~cm}$, membranaceous or subcoriaceous, subglabrous or hairy or tomentose beneath, rarely on both sides, apex acute to cuspidate-acuminate, base more or less oblique, slightly cordate, rarely rounded, midrib and nerves flat above, prominent beneath, nerves 6-8 pairs, ascending at an angle of c. $60^{\circ}$, nervules subparallel, conspicuous beneath; petioles 1-3 $\mathrm{mm}$ long, tomentose. Stipules triangular or ovate-lanceolate, $2-3 \mathrm{~mm}$ long, densely tomentose. Inflorescences cymose, sessile, 3-4-flowered, covered by persistent bracts; bracts subulate to lanceolate, 6-15 mm long, tomentose. Flowers sessile, 10-15 mm long; calyx campanulate, $2-3 \mathrm{~mm}$ long, hirsute, with 5 triangular teeth, hirsute; corolla 10-12 mm long, 5-lobed, sparsely hirsute outside, villous inside. Drupes globose or ovoid, 5-10 mm diam, crowned with lanceolate, hirsute calyx lobes; pyrenes 5 .

Distribution - Nepal, Bhutan, NE India, China, S Japan, Vietnam, Laos, Cambodia, Burma, Thailand, Malaysia (Peninsular and Borneo), Brunei, Philippines, Indonesia (Sumatra, Java, Kalimantan, Sulawesi, Lesser Sunda Islands), Papua New Guinea.

Notes - Jack's type specimens were destroyed with greater part of his undistributed duplicates by fire in 1824 (Merrill 1952, Stafleu \& Cowan 1979). Fortunately, a specimen of $L$. attenuatus with Jack's own handwriting on the label was traced in $\mathrm{L}$ by Merrill (1952), which greatly helps us to interpret this name. Lasianthus attenuatus is a widely distributed species in tropical Asia. Several different specific and varietal names were used by different authors. Lasianthus wallichii was used for the populations from India, Burma, Bangladesh, Thailand, Indochina, and SW China; L. plagiophyllus was used for the population from the Philippines (also L. bodinieri and L. copelandi), Taiwan, SE
China; L. densifolius for the populations from Malaysia (also $L$. bractescens) and Java, and $L$. attenuatus for the one from Sumatra. In New Guinea, a variety of $L$. attenuatus was established (and also L. brachyphyllus). These species and varieties were recognized based mainly on variation of indumentum (e.g. hairs on both sides of leaves, on lower surface or both lower surface and midrib above), leaf-blade shapes (oblong or attenuated to the apex), length of petioles, etc. However, these characteristics vary continuously through almost the whole of its geographical area and show no clear geographically distinct groups.

Specimens that were identified as $L$. copelandii from the Philippines were a mixture of $L$. attenuatus and $L$. cyanocarpus. According to Merrill's original description, $L$. copelandii has oblong or oblong-lanceolate leaves with acuminate apex and unequally subcordate bases, and lanceolate bracts. These match $L$. attenuatus better than $L$. cyanocarpus. Therefore, $L$. copelandii is considered to be conspecific with $L$. attenuatus although its type has not been seen.

The type of $L$. brachyphyllus could be in Berlin. However, there is no folder of type specimens of Lasianthus in Berlin. It was certainly destroyed in the war in 1943. From original the description and Valeton's comments on it, L. brachyphyllus is mostly equal to $L$. wallichii Wight, i.e. the present $L$. attenuatus. After all collections from New Guinea in $K$ and $L$ were checked, we are sure that $L$. brachyphyllus is conspecific with $L$. attenuatus.

Lasianthus densifolius var. latifolia, according to King \& Gamble (1904) and one syntype in SING, differs from the typical variety in having broadly oblong leaves and multi-cellular stiff hairs on both sides of leaves and branches. These characters of stiff or setose hairs on plants are found frequently in the population of $L$. densifolius, and are not of clear demarcation. Lasianthus densifolius var. calycinus, also from King \& Gamble's description, differs from the typical variety in having leaves glabrous above except for a very few scattered appressed hairs, strigose midrib, less than 8 pairs of nerves, and the drupes crowned by calyx-lobes which are as long as the drupes. In our observations, both var. calycinus and var. latifolia cannot be separated from the typical variety. We agree with Wong (1989) who sank L. densifolius var. latifolia and var. calycinus.

Lasianthus attenuatus was often confused with L. cyanocarpus (L. inaequalis Blume). As pointed out by Merrill (1952), it strongly resembles $L$. cyanocarpus except in having different

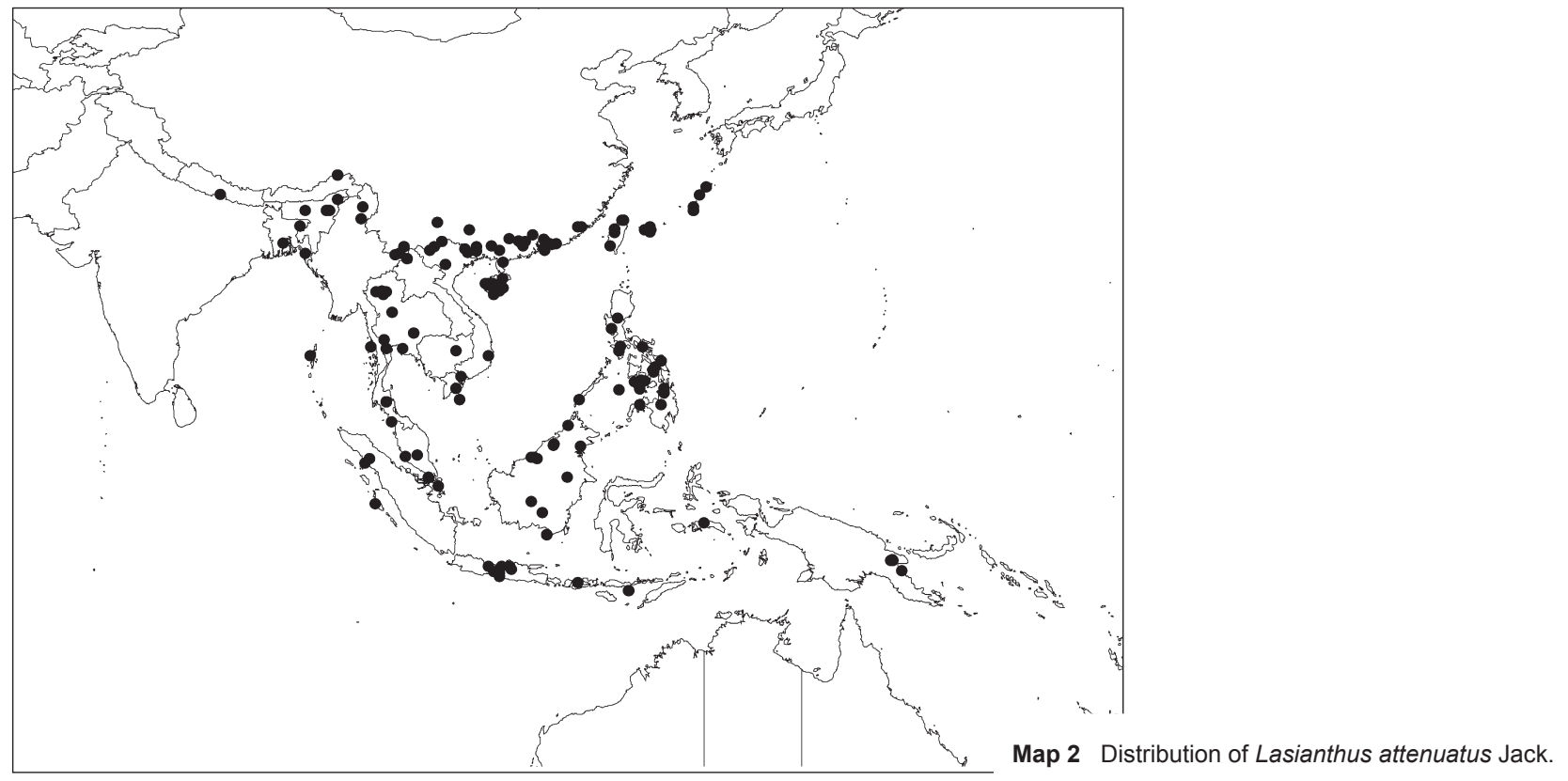




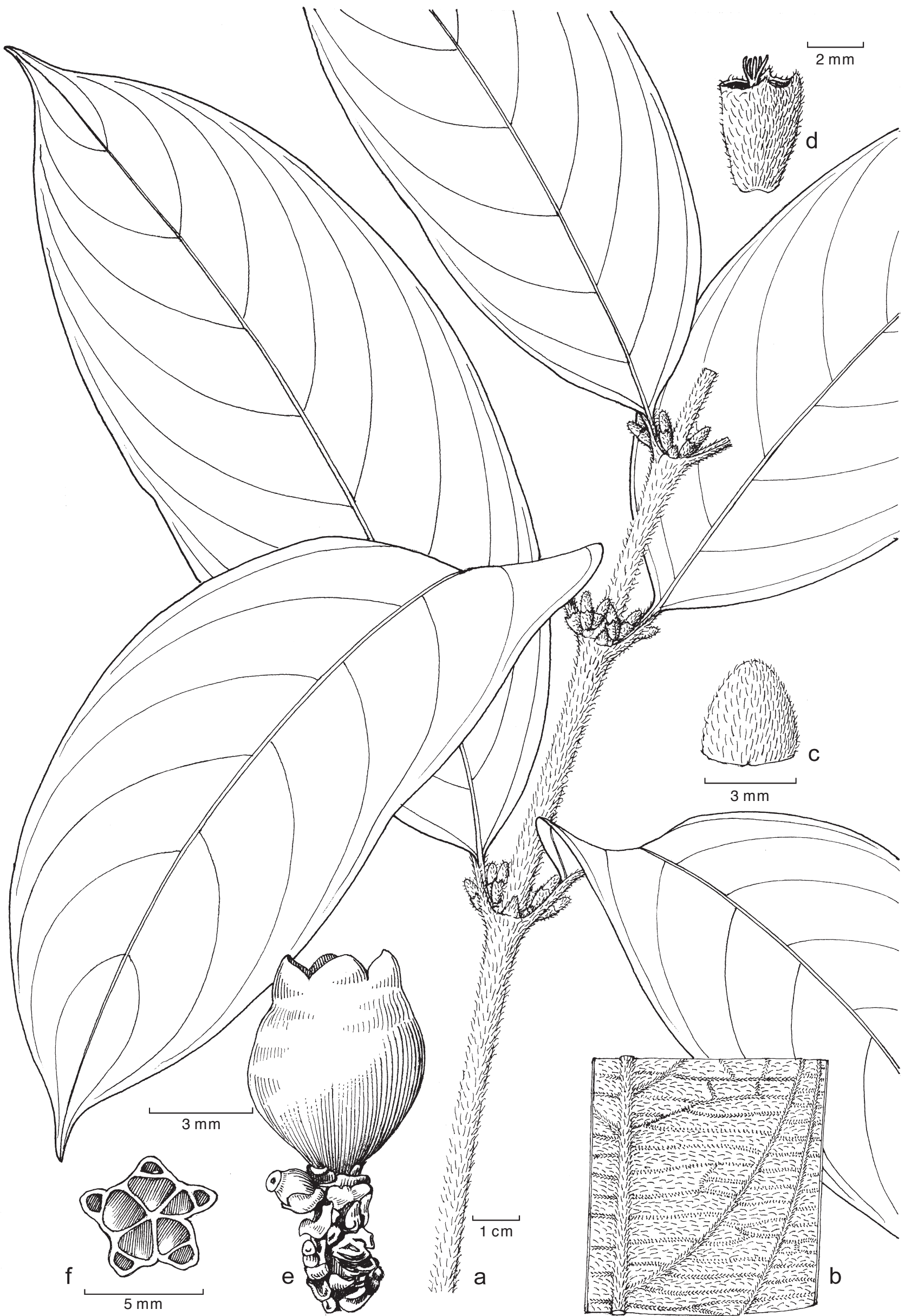

Fig. 2 Lasianthus baasianus H.Zhu. a. Habit with inflorescences; b. detail of lower surface of leaf showing subreticulate nervules; c. stipule; d. flower without corolla; e. fruits on shortly tuberculate inflorescence; f. cross section of fruit (all: Nooteboom 4189, holo L). 
bracts. Lasianthus attenuatus has linear to lanceolate bracts, while $L$. cyanocarpus has larger and cordate, ovate to broadly lanceolate, somewhere leaf-like bracts.

The syntype of $L$. densifolius in L (Junghuhn s.n.) agrees exactly with the type of $L$. wallichii. However, Hooker's description and the cited specimen Wall. Cat. $8441(\mathrm{~K})$ as L. densifolius does not agree with Miquel's type. It represents a different variety. King \& Gamble (1904), Ridley (1923a) and Wong (1989) followed Hooker's conception and mixed them. Here we treat the different variety as a new variety of $L$. attenuatus.

\section{b. var. minor H.Zhu, var. nov.}

A var. attenuato foliis minoribus lineario-oblongis $2 \mathrm{~cm}$ latis, stipulis triangulelanceolatis 5-8 $\mathrm{mm}$ longis, bracteis et floribus minoribus differt. - Typus: J.F.Maxwell 82-72 (holo L), Singapore, Nee Soon, swamp forest.

Lasianthus densifolius Miq. (1857) 321, p.p. quoad syntype: Horsfield s.n. (K), Blambangan, Java.

Lasianthus densifolius auct. non Miq.: Hook.f. (1880) 182, cited specimen Lasianthus? Wall. Cat. 8441 in part; King \& Gamble (1904) 122; Ridl. (1923a) 156; K.M.Wong (1989) 368, p.p.]

This variety has relatively small linear-oblong leaves which are less than $2 \mathrm{~cm}$ broad, triangular-lanceolate and hirsute stipules which are $5-8 \mathrm{~mm}$ long, relatively small and subulate to linear bracts which are $5 \mathrm{~mm}$ long, and relatively small flowers which are $8 \mathrm{~mm}$ long.

Distribution - Peninsular Malaysia, Singapore, Indonesia (Sumatra).

Habitat \& Ecology — In swamp forest and lowland forests. Flowering and fruiting between January and March.

Note - The var. attenuatus differs from var. minor in having oblong leaves which are more than $2 \mathrm{~cm}$ broad, inconspicuous stipules, relatively large bracts and flowers.

\section{Lasianthus baasianus H.Zhu, sp. nov. - Fig. 2}

Proximus L. longifolio Wight, sed ramulis, foliis subtus et calycibus puberulis, stipulis minoribus, floribus minoribus atque limbis calycis ad maturitatem fructus $2 \mathrm{~mm}$ longis differt. A L. pseudolongifolio H.Zhu ramulis foliisque subtus puberulis et limbis calycis cupulatis truncatis differt. - Typus: Nooteboom 4189 (holo L), Borneo, Bukit Raya, $112^{\circ} 45^{\prime} \mathrm{E}, 0^{\circ} 45^{\prime} \mathrm{S}, 1300 \mathrm{~m}$ alt., in primary dipterocarp forest, 5 Dec. 1982

Treelet, $3 \mathrm{~m}$ high; branchlets robust, compressed or subangular, fistulous, c. $5 \mathrm{~mm}$ diam, pubescent to glabrescent. Leaves: blades elliptic-oblong, $18-30$ by $6-11 \mathrm{~cm}$, coriaceous, glabrous above, puberulous beneath, apex cuspidate, base acute to subrounded, midrib prominent above, conspicuously prominent beneath, puberulous beneath, nerves depressed to flat above, prominent beneath, 9 pairs, ascending at an angle of $50-70^{\circ}$, curved to the margin, puberulous beneath, nervules clear above, prominent beneath, subreticulate, puberulous beneath; petioles $1-3 \mathrm{~cm}$ long, puberulous. Stipules triangular, 3 by 3 $\mathrm{mm}$, pubescent. Inflorescences sessile, or shortly tuberculate; bracts inconspicuous. Flowers fascicular, sessile; calyx 3-4 $\mathrm{mm}$ long, pubescent, limb cupular, truncate or 4 minutely teeth; corolla 6-7 mm long, upper part puberulous external surface, lobes 4 , lanceolate, $3 \mathrm{~mm}$ long, puberulous external surface, flocculous internal surface. Drupes subglobose, 5 by $6 \mathrm{~mm}$, with 5 conspicuous ridges, puberulous, crowned by persistent cupular calyx limbs; calyx limbs $2 \mathrm{~mm}$ long; pyrenes 5, smooth on the abaxial face, subelliptic in transverse section.

Distribution - Endemic to Borneo.

Habitat \& Ecology — In lowland primary dipterocarp forest between 100-500 m altitude. Flowering between April and December; fruiting in January.

Additional specimens examined. Sarawak, Paul Chai S.34053 (L); Central Kalimantan, J.P. Mogea et al. 4019 (L); Borneo, Bukit Raya, Veldkamp 8003
(L), Nooteboom 4735 (L); Central Kalimantan, A.C. Church et al. 888 (L), $937(\mathrm{~K}, \mathrm{~L})$.

Note - This species is close to L. longifolius Wight. It differs from the latter by having pubescent branchlets, leaves beneath and calyx; smaller stipules ( 3 by $3 \mathrm{~mm}$ ) and relatively small flowers (up to $8 \mathrm{~mm}$ long); drupe crowned by $2 \mathrm{~mm}$ long calyx limb. While $L$. longifolius has glabrous branchlets, leaves and calyx; stipules up to $1 \mathrm{~cm}$ long; flowers up to $3 \mathrm{~cm}$ long; drupes crowned by $5 \mathrm{~mm}$ long enlarged cupular calyx limb. It differs from L. pseudolongifolius by having pubescent branchlets, leaves beneath, and cupular, truncate calyx limbs.

\section{Lasianthus barbatus H.Zhu, sp. nov. - Fig. 3}

Proximus $L$. glabro Ridl., sed foliis lanceolatis, $1.3-2.5 \mathrm{~cm}$ latis, nervulis subtus conspicuis, parallelis atque stipulis et bracteis minoribus differt. - Typus: T. Suppiah s.n. KEP 104817 (holo L), Peninsular Malaysia, Kelantan, Ulu Sat FR., in primary forest, 13 June 1968.

Shrub, $2 \mathrm{~mm}$ high; branchlets terete, c. $2 \mathrm{~mm}$ diam, glabrous, brown. Leaves: blades lanceolate, $8-12$ by $1.3-2.5 \mathrm{~cm}$, subcoriaceous, glabrous except sparsely hirsute nerves beneath, apex caudate, aristate, arista $2 \mathrm{~mm}$ long, base acuminate to acute, midrib slightly depressed above, prominent beneath, glabrous, nerves flat above, prominent beneath, 5-6 pairs, ascending at an angle of $50-60^{\circ}$, curved to margin, sparsely hirsute beneath, nervules obscure above, conspicuous beneath, parallel, glabrous; petioles c. $5 \mathrm{~mm}$ long, glabrous. Stipules ovate-triangular to broadly triangular, $4-5$ by $4 \mathrm{~mm}$, glabrous except barbate margin. Inflorescences axillary, sessile; bracts ovate-triangular, glabrous except barbate margin, $4-5$ by $2-4 \mathrm{~mm}$; bracteoles ovate-triangular, glabrous except barbate margin. Flowers fascicular, sessile. Drupes subglobose, $4-5$ by $4 \mathrm{~mm}$, with 5 obtuse ridges, glabrous; calyx lobes persistent, lanceolate, $1 \mathrm{~mm}$ long, hirsute; pyrenes 4-5, smooth on the abaxial face, sulcate on the adaxial and the side faces in transverse section.

Distribution - Endemic to Peninsular Malaysia.

Habitat \& Ecology — In primary forest. Fruiting in June.

Note - This species has stipules and bracts with barbate margins as $L$. glaber. It differs from the latter by having lanceolate leaves less than $2.5 \mathrm{~cm}$ broad, nervules conspicuous beneath, parallel, relatively small stipules and bracts; while L. glaber has elliptic-oblong leaves, $12-18$ by $4-5.5 \mathrm{~cm}$, nervules obscure on both surfaces, relatively large stipules and bracts. It is close to $L$. foxworthyanus, but differs from the latter by having glabrous branchlets and leaves, leaves lanceolate, nerves 5-6, stipules and bracts ovate-triangular, glabrous except barbate margins, drupes with $4-5$ pyrenes.

\section{Lasianthus barbiger Ridl.}

Lasianthus barbiger Ridl. (1917b) 52. - Type: Robinson \& Kloss s.n. (holo $\mathrm{BM}$; iso K), Sumatra, Korinchi.

Shrubs, up to $3 \mathrm{~m}$ high; branchlets usually compressed, $2-3 \mathrm{~mm}$ diam, hirsute. Leaves: blades ovate-elliptic, $9-13$ by $3.5-5 \mathrm{~cm}$, subcoriaceous, sparsely hirsute on midrib and nerves both sides, apex shortly caudate or cuspidate, base cuneate, midrib and nerves slightly depressed above, prominent beneath, nerves 10-11 pairs, ascending at an angle of c. $70^{\circ}$, curved to the margin, nerves prominent and sparsely hirsute beneath, subreticulate; petioles c. $1 \mathrm{~cm}$ long, hirsute. Stipules $0.5-1 \mathrm{~cm}$ long, lanceolate-oblong to ovate-oblong, membranaceous, with a broad base and an obtuse apex, sparsely hirsute. Cymes sessile; bracts inconspicuous. Flowers sessile, 4-merous; calyx tubular, with a campanulate limb, calyx tube c. $2 \mathrm{~mm}$ long, glabrous, calyx limb with 4 lanceolate c. $1.5 \mathrm{~mm}$ long lobes, barbate at margin; corollas unknown. Drupes ovoid, 5 by $8 \mathrm{~mm}$, 


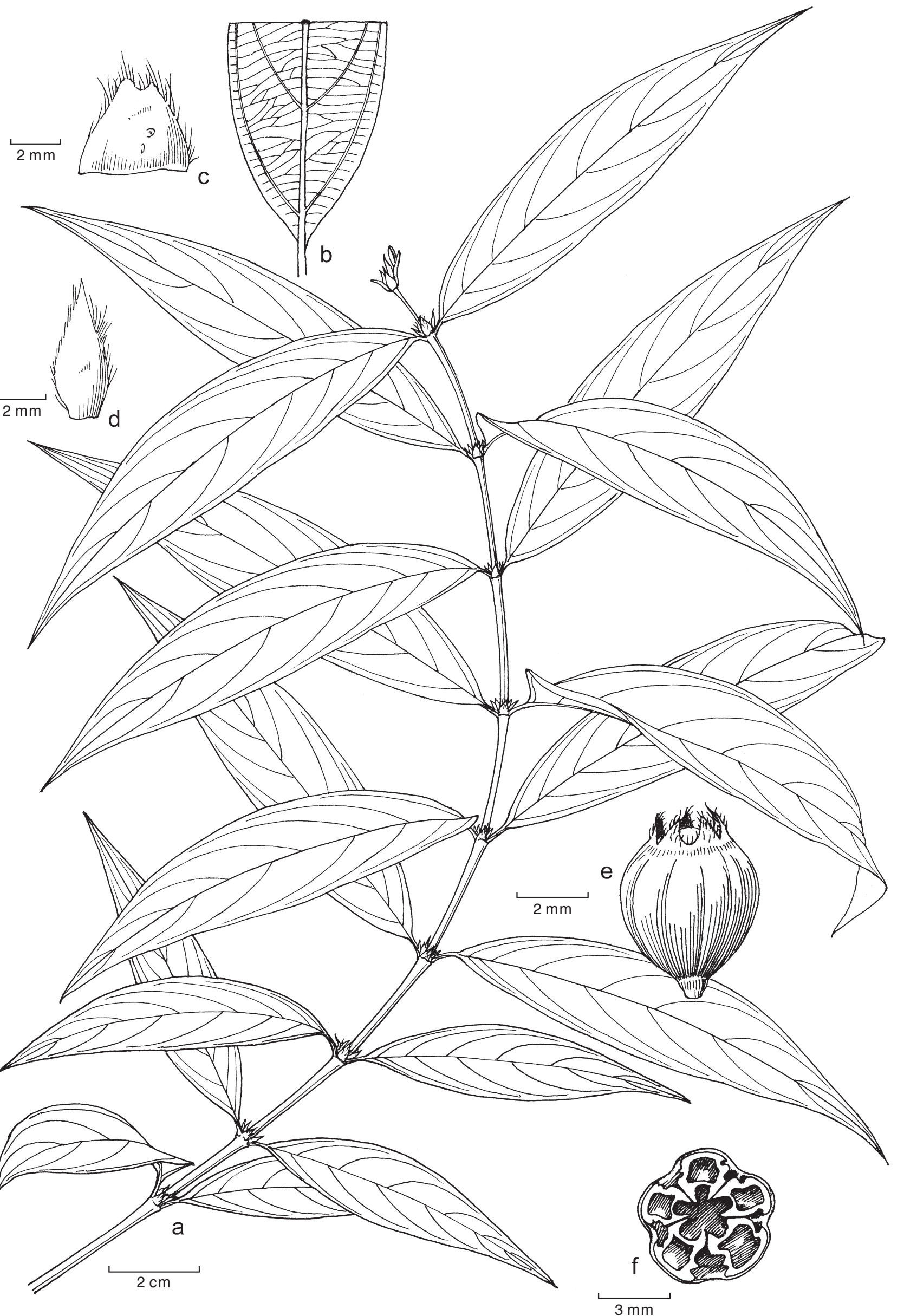

Fig. 3 Lasianthus barbatus H.Zhu. a. Habit; b. detail of lower surface of leaf; c. stipule; d. bract; e. fruit; f. cross section of fruit (all: T. Suppiah s.n. KEP 104817, holo L). 


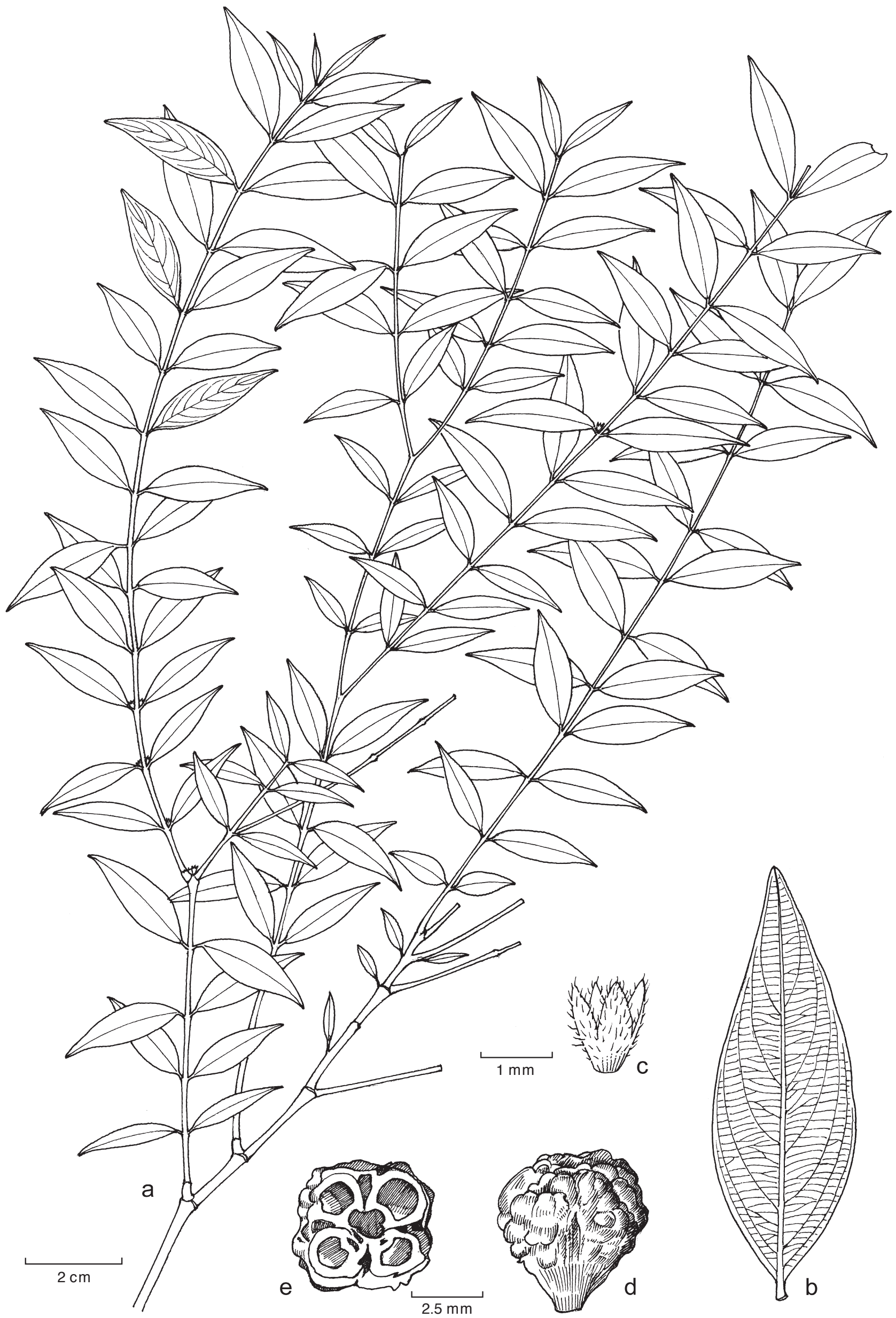

Fig. 4 Lasianthus bifloroideus H.Zhu. a. Habit; b. detail of lower surface of leaf showing parallel nervules; c. calyx; d. fruit; e. cross section of fruit (all: Paul Chai S.33809, holo L). 
narrow at base, with 4 obtuse ridges, crowned by persistent calyx lobes, glabrous; pyrenes 4 , verrucose on the abaxial face. Distribution - Endemic to Sumatra.

Note - This species has large membranaceous stipules similar to those of the closely related species $L$. pseudostipularis and L. stipularis. It differs from L. pseudo-stipularis by having hirsute branchlets, ovate-elliptic leaves with hirsute nerves beneath, calyx lobes lanceolate, barbate at margin. It differs from $L$. stipularis by having hirsute branchlets, ovateelliptic leaves with hirsute nerves beneath, inconspicuous bracts, calyx lobes lanceolate, barbate at margin.

\section{Lasianthus bifloroideus H.Zhu, sp. nov. - Fig. 4}

Similis L. bifloro (Blume) M.Gangop. \& Chakrab., sed ramulis rare puberulis, foliis ovato-lanceolatis glabris, cymis sessilis vel subsessilis, lobis calycis ovato-oblongis longioribus tubo et pyrenis conspicue verrucatis differt. Typus: Paul Chai S.33809 (holo L; iso K), Borneo, Lubok Antu, Bukut Peninjau, in valley bottom, 13 Mar. 1974.

Small shrub, 1-2 m high, branchlets terete, slender, less than $1 \mathrm{~mm}$ diam, puberulous. Leaves: blades very small, ovatelanceolate, $1.5-3$ by $0.5-1 \mathrm{~cm}$, chartaceous, glabrous on both surfaces, apex acuminate, mucronate, base acute; midrib slightly prominent above, prominent beneath, nerves slender, flat above, prominent beneath, 5 pairs, ascending at an angle of c. $60^{\circ}$, curved to margin, nervules weak, slender, parallel; petioles short, less than $1 \mathrm{~mm}$ long, puberulous. Stipules lanceolate, c. $1 \mathrm{~mm}$ long, puberulous. Inflorescences sessile or subsessile, bracts absent. Flowers very small; calyx c. $1 \mathrm{~mm}$ long, sparsely puberulous, calyx lobes 4 , ovate-oblong, c. 0.7 $\mathrm{mm}$ long; corolla not seen. Drupes subglobose, 4-5 mm diam, glabrous, 4-ridged, crowned by $4 \mathrm{c}$. $1 \mathrm{~mm}$ long ovate-oblong calyx lobes; pyrenes 4 , warty on abaxial face, orbicular in transverse section.

Distribution - Endemic to Borneo (Lukok Antu).

Habitat \& Ecology — Valley bottom near river. Flowering and fruiting in March.

Note - This species is closely related to L. biflorus, but differs from the latter by having branchlets thinly puberulous, leaves ovate-lanceolate glabrous, cymes sessile or subsessile, calyx lobes ovate-oblong longer than calyx tube, drupes more warty. Lasianthus biflorus has branchlets hirsute, leaves subrhombic to elliptic-obovate, hirsute midrib and nerves beneath, cymes with 5-15 mm long peduncles, drupes less warty.
11. Lasianthus biflorus (Blume) M.Gangop. \& Chakrab. Map 3

Lasianthus biflorus (Blume) M.Gangop. \& Chakrab. (1992) 338; H.Zhu (2002) 100. - Litosanthes biflora Blume (1826-1827) 994. - Type: Blume s.n. (lecto L, designated by Zhu 2002, barcode L0000722), Java.

Lasianthus gracilis King \& Gamble (1904) 132; Ridl. (1923a) 169; K.M.Wong (1989) 367. - Type: Ridley 2904 (lecto SING, designated by Wong 1988), Peninsular Malaysia.

Lasianthus gainii M.Gangop. \& Chakrab. (1992) 338. - Litosanthes gracilis Hayata (1912) 113. - Syntypes: Hayata \& Sasaki s.n. (n.v.), Kusukusu; G. Nakahara s.n. (n.v.), Botanrosha.

Shrubs, 1-2 m high; branchlets terete, densely hirsute. Leaves: blades chartaceous, subrhomboid or elliptic-obovate, 1.5-2.5 by $0.8-1.5 \mathrm{~cm}$, apex acute, often mucronulate, base cuneate, glabrous above, hirsute beneath, midrib depressed above, prominent beneath, hirsute beneath, nerves flat above, prominent beneath, $6-8$ pairs, hirsute beneath, nervules obscure on both surfaces; petioles 1-2 mm long, hirsute. Stipules small, inconspicuous. Cymes with peduncles $0.5-1.5 \mathrm{~cm}$ long, hirsute; bracts small, inconspicuous. Flowers with pedicels c. $1 \mathrm{~mm}$ long; calyx campanulate, c. $2 \mathrm{~mm}$ long, glabrous, calyx limb with 5 triangular teeth; corolla 2-4 mm long, glabrous outside, lobes ovate. Drupes ovoid, c. 4-5 mm diam, glabrous, verrucose, 4-grooved; pyrenes 4.

Distribution - China (S Yunnan, Hainan, Taiwan), mainland SE Asia, Malaysia (Peninsular, Borneo), Philippines, Indonesia (Sumatra, Java, Kalimantan, Sulawesi, Lesser Sunda Islands).

\section{Lasianthus borneensis Merr.}

Lasianthus borneensis Merr. (1929a) 292. - Type: Elmer 21212 (iso CAS, HUH, K, L, MO, SING, U), Elmer 21656 (para MO, SING), Borneo, Tawao. Lasianthus sepalinus Ridl. (1934) 120, syn. nov. - Type: Ridley 9703 (holo K), Borneo, Bongaya, Labuk Bay; Clemens 9467 (para SING), Sandakan.

Shrubs, c. 1-2 m high; branchlets terete, c. 2 mm diam, densely appressed-pubescent, virid to brown. Leaves: blades oblong to oblong-lanceolate, $10-22$ by $3-5.5 \mathrm{~cm}$, coriaceous to subcoriaceous, glabrous and nitid above except midrib, densely shorthirsute or hispid beneath, apex shortly caudate-acuminate, base acute to subrounded, slightly asymmetric, midrib, nerves and nervules flat to slightly prominent above, conspicuously prominent beneath, nerves 8-10 pairs, ascending at an angle of $60-70^{\circ}$, curved to the margin; nervules parallel; petioles 8-10 mm long, densely pubescent. Stipules oblong-ovate to lanceolate, 2-3 mm long, densely pubescent. Cymes sessile; bracts absent. Flowers sessile, 5-merous; calyx campanulate,

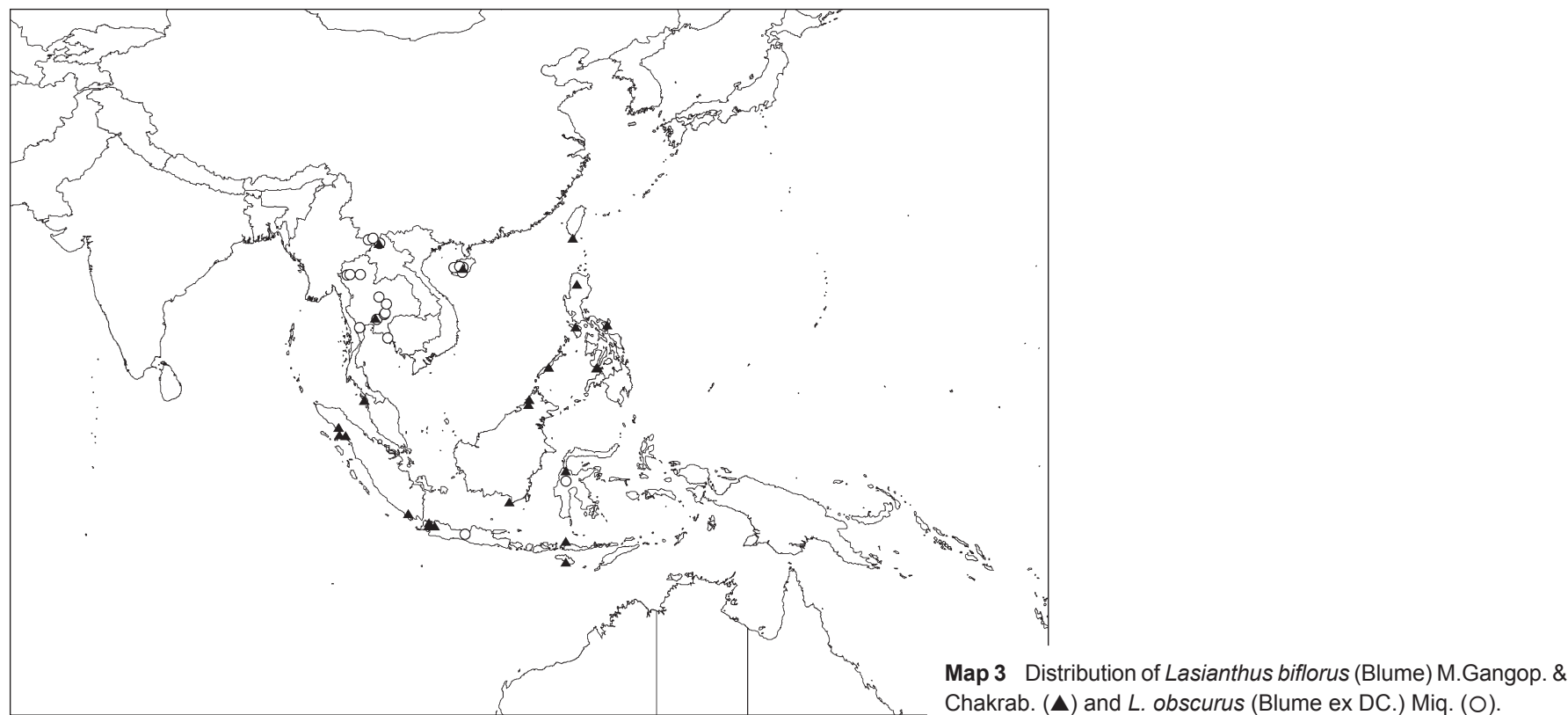

Chakrab. (A) and L. obscurus (Blume ex DC.) Miq. (○). 


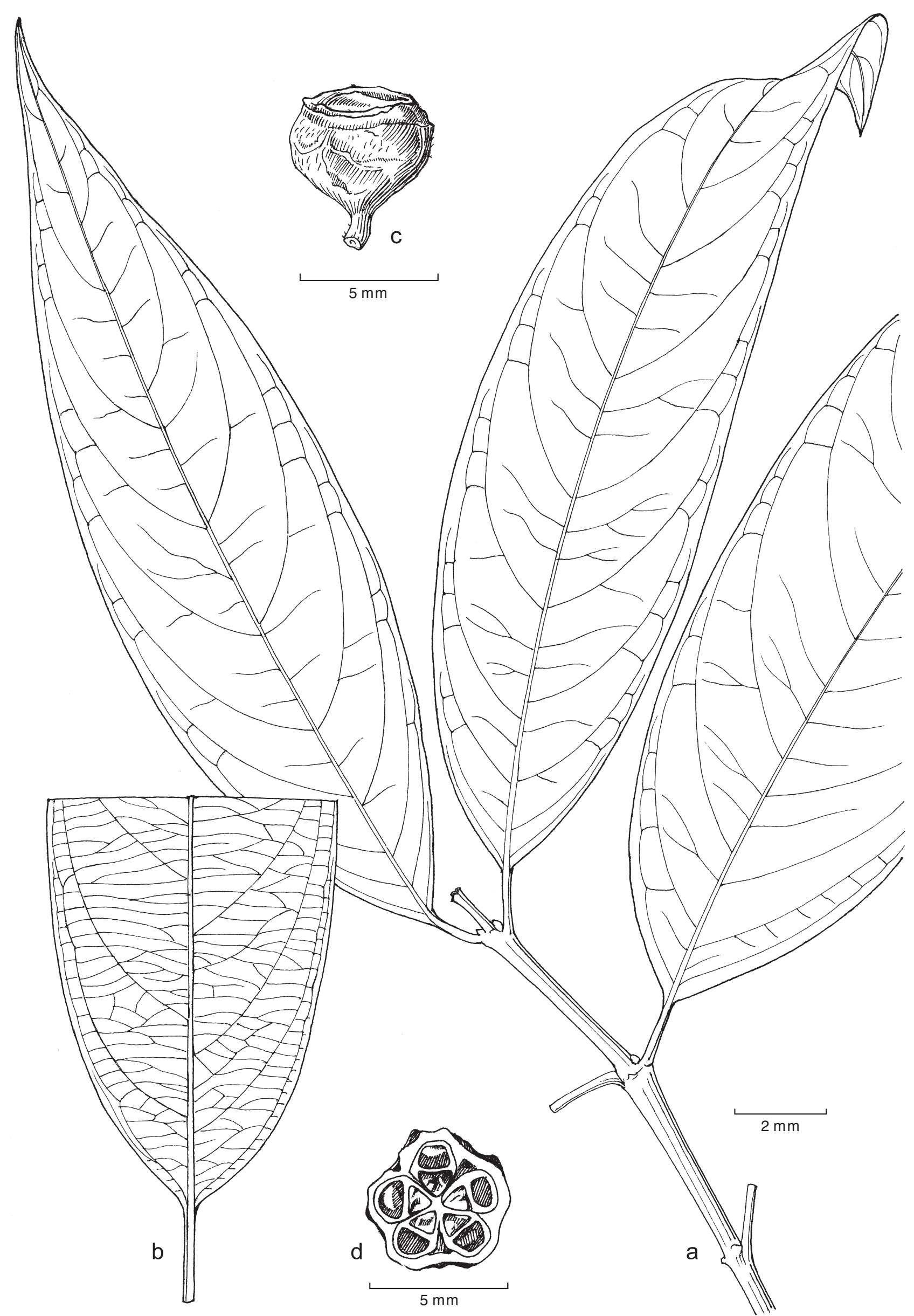

Fig. 5 Lasianthus brevipedicellatus H.Zhu. a. Habit; b. lower surface of leaf showing subparallel nervules; c. fruit; d. cross section of fruit (all: Y.P. Ching S.55288, holo L). 
hirsute, calyx tube c. $2 \mathrm{~mm}$ long, lobes 5, oblong, c. $3 \mathrm{~mm}$ long; corolla tube cylindrical, c. $6 \mathrm{~mm}$ long, pubescent outside, villose inside; corolla lobes 5, oblong, acute at apex, $3 \mathrm{~mm}$ long, pubescent outside, floccose inside; anthers oblong, c. $1.5 \mathrm{~mm}$ long. Drupes globose, c. $5 \mathrm{~mm}$ diam, with 5 obtuse ridges, hirsute, crowned by 5 large oblong calyx lobes; pyrenes 5 .

Distribution - Malaysia (Borneo) and Brunei.

Note - This species is easily recognized by its hispid leaves, relatively large calyx and oblong calyx lobes with an obtuse apex. It is closely related to $L$. setulosus also from Borneo. Lasianthus setulosus differs in having densely spreading long hispid on branchlets and both surfaces of leaves, a relatively small calyx, 3 by $3 \mathrm{~mm}$, with ovate-triangular calyx lobes with acute apex.

\section{Lasianthus bracteolatus Miq.}

Lasianthus bracteolatus Miq. (1869) 246; Bakh.f. (1965) 337. — Type: Junghuhn s.n. (holo L, barcode L 0057503; iso L, barcode L0057504, L, barcode L0057505), Sumatra, Tapanuli.

Shrubs; branchlets terete, 2-3 $\mathrm{mm}$ diam, densely appressedpubescent to subglabrous, brown. Leaves: blades elliptic to obovate-elliptic, $9-13$ by $4-6 \mathrm{~cm}$, subcoriaceous, glabrous above, pubescent on midrib, nerves and nervules beneath, apex shortly caudate to cuspidate, base rounded to subrounded, slightly asymmetric, midrib and nerves flat above, prominent beneath, nerves $7-8$ pairs, ascending at an angle of $60-70^{\circ}$, curved to the margin, nervules obscure above, prominent beneath, subparallel; petioles $4-5 \mathrm{~mm}$ long, densely pubescent. Stipules triangular-subulate, c. $4 \mathrm{~mm}$ long, densely pubescent. Cymes sessile; bracts linear, 5-6 mm long, densely pubescent. Flowers sessile; calyx campanulate, densely pubescent, tube c. $2 \mathrm{~mm}$ long, lobes 5 , subulate, c. $1 \mathrm{~mm}$ long; corolla not seen. Drupes globose, c. $3 \mathrm{~mm}$ diam, pubescent, crowned by subulate calyx lobes; pyrenes 4-5, smooth on the abaxial face.

Distribution - Indonesia (Java and Moluccas).

Note - This species has elliptic to obovate-elliptic leaves with 7-8 pairs of nerves, bracts linear, and drupes with 4-5 pyrenes. It differs from $L$. rigidus by having relatively small leaves with rounded base, longer petioles, bracts linear and shorter, calyx lobes subulate, small and smaller pubescent drupes.

\section{Lasianthus brevipedicellatus H.Zhu, sp. nov. - Fig. 5}

Similis $L$. vrieseano Miq, sed foliis chartaceis vel subcoriaceis, basi acutis differt. A L. perakensis King \& Gamble foliis glabris et drupis pedicellatis 5-6-porcatis apice truncatis differt. - Typus: Ching S. 55288 (holo L), Borneo, Sarawak, Sg. Palog, 850 m alt., in dipterocarp forest, 24 Sept. 1987.

Treelet, $3 \mathrm{~m}$ high; branchlets terete, compressed in the youngest part, c. $3 \mathrm{~mm}$ diam, puberulous, fistulous. Leaves: blades elliptic to oblong-elliptic, $19-23$ by $5-8 \mathrm{~cm}$, chartaceous to subcoriaceous, glabrous on both surfaces, apex cuspidate to falcate-acuminate, mucronate, base acute, midrib slightly depressed or flat above, conspicuously prominent beneath, nerves prominent on both surfaces, 7-9 pairs, ascending at an angle of $50-60^{\circ}$, curved to margin, glabrous, nervules prominent on both surfaces, subparallel, glabrous, margin recurved; petioles $1-1.5 \mathrm{~cm}$ long, puberulous or subglabrous. Stipules triangular, 1.5-2 mm long, often deciduous. Inflorescences sessile; bracts absent. Flowers not seen. Drupes stalked, fascicular; pedicels short, 1.5-2 mm long, slender, glabrous; drupes subglobose, sparsely puberulous, warty, 5-6 conspicuously obtuse ridges; pyrenes $5-6$, slightly warty on the abaxial face.

Distribution - Malaysia (Peninsular and Sarawak).

Habitat \& Ecology — In montane forest between 850-1000 $m$ altitude. Fruiting in September.
Additional specimen examined. Peninsular Malaysia, Gunong Tapis, 3000 $\mathrm{ft}$, KEP-FRI 10973 (L).

Note - This species is characterized by its stalked drupes, very small stipules, bracts absent and glabrous leaves with subparallel nervules prominent on both surfaces. It is very closely related to $L$. vriesianus, but differs from the latter by having chartaceous to subcoriaceous leaves with acute base and smaller flowers. Lasianthus vriesianus has thickly coriaceous leaves with subrounded base. In $L$. vriesianus, only the type with few immature drupes has been seen. More other diagnostic characteristics between these two species cannot be recognized because of insufficient collections. This species is also similar to $L$. perakensis, but differs from the latter by having glabrous leaves, pediceled drupes with 5-6 ridges, while L. perakensis has puberulous leaves on nerves beneath, sessile drupes with 10-ridged pyrenes and crowned by persistent obtuse spreading calyx lobes.

\section{Lasianthus brevipedunculatus H.Zhu, sp. nov. - Fig. 6}

Proximus L. nervosus King \& Gamble, sed foliis majoribus $4.5-8 \mathrm{~cm}$ longis $2-3$ $\mathrm{cm}$ latis, cymis brevipedunculatis, floribus 5-meris, lobis calycis triangulatooblongis et pyrenis 5 differt. - Typus: Nagamasu 3359 (holo L), W Sumatra, Gunung Sago, 2100-2260 m alt., in upper montane forest around the summit, 30 Oct. 1988.

Shrub, c. $2 \mathrm{~m}$ high; branchlets terete, c. $1.5 \mathrm{~mm}$ diam, densely brown-yellowish tomentose. Leaves elliptic-oblong to ovateoblong, $4.5-8$ by $2-3 \mathrm{~cm}$, coriaceous, glabrous above, puberulous beneath, densely tomentose hairs on midrib and nerves beneath, apex acute or cuspidate, base subrounded, midrib depressed above, prominent beneath, nerves flat or slightly depressed above, prominent beneath, 5-6 pairs, ascending at an angle of $50-60^{\circ}$, curved to margin, nervules prominent on both surfaces, parallel, margin hirsute; petioles 4-6 mm long, densely tomentose. Stipules triangular, $2 \mathrm{~mm}$ long, densely tomentose. Inflorescences shortly peduncled; peduncles 1-3 $\mathrm{mm}$ long, densely tomentose; bracts 1-2, linear, c. $2 \mathrm{~mm}$ long, tomentose. Flowers sessile; calyx hirsute external surface, lobes 5 , oblong or lanceolate-oblong, $3 \mathrm{~mm}$ long, tube very short, less than $1 \mathrm{~mm}$ long; corolla $4-5 \mathrm{~mm}$ long, tomentose external surface, lobes 5, triangular-oblong, 2-3 mm long; stamens 5; ovary with 5 locules. Drupes c. $4 \mathrm{~mm}$ diam, subglobose, subglabrous, crowned by 5 calyx lobes; pyrenes 5 .

Distribution - Indonesia (W Sumatra). tude.

Habitat \& Ecology — In upper montane forest at $2100 \mathrm{~m}$ alti-

Note - This species is closely related to $L$. nervosus from Malaysian mountains. It differs from the latter by having relatively large leaves $(4.5-8$ by $2-3 \mathrm{~cm})$, cymes shortly peduncled, flowers 5-merous, calyx lobes triangular-oblong, and drupes with 5 pyrenes. Lasianthus nervosus has leaves of $2.5-3.5$ by $1.5 \mathrm{~cm}$, cymes sessile, flowers 4-merous, calyx with triangular teeth, and drupes with 4 pyrenes.

\section{Lasianthus brochidodromus H.Zhu, sp. nov. - Fig. 7}

Proximus L. membranaceoideus H.Zhu, sed foliis lanceolatis $2-2.5 \mathrm{~cm}$ latis, drupis minoribus puberulis obtuse 4-5-porcatis et pyrenis abaxiali leviter verrucosis differt. - Typus: Gaerlan et al. PPI 23712 (holo L), Philippines, Luzon, Quezon, Alabat Isl., 175 m alt., in dipterocarp forest, 25 March 1996.

Shrub, c. $1.5 \mathrm{~m}$ high; branchlets terete, compressed at nodes, c. $1.5 \mathrm{~mm}$ diam, glabrous. Leaves: blades lanceolate, glabrous except puberulous nerves and margin beneath, $10-15$ by $2-2.5$ $\mathrm{cm}$; subcoriaceous, apex acuminate, margin slightly undulate and recurved, base acute, midrib slightly prominent above, strongly prominent beneath, nerves prominent on both surfaces, 9-12 pairs, ascending at an angle of c. $90^{\circ}$, curved near margin 

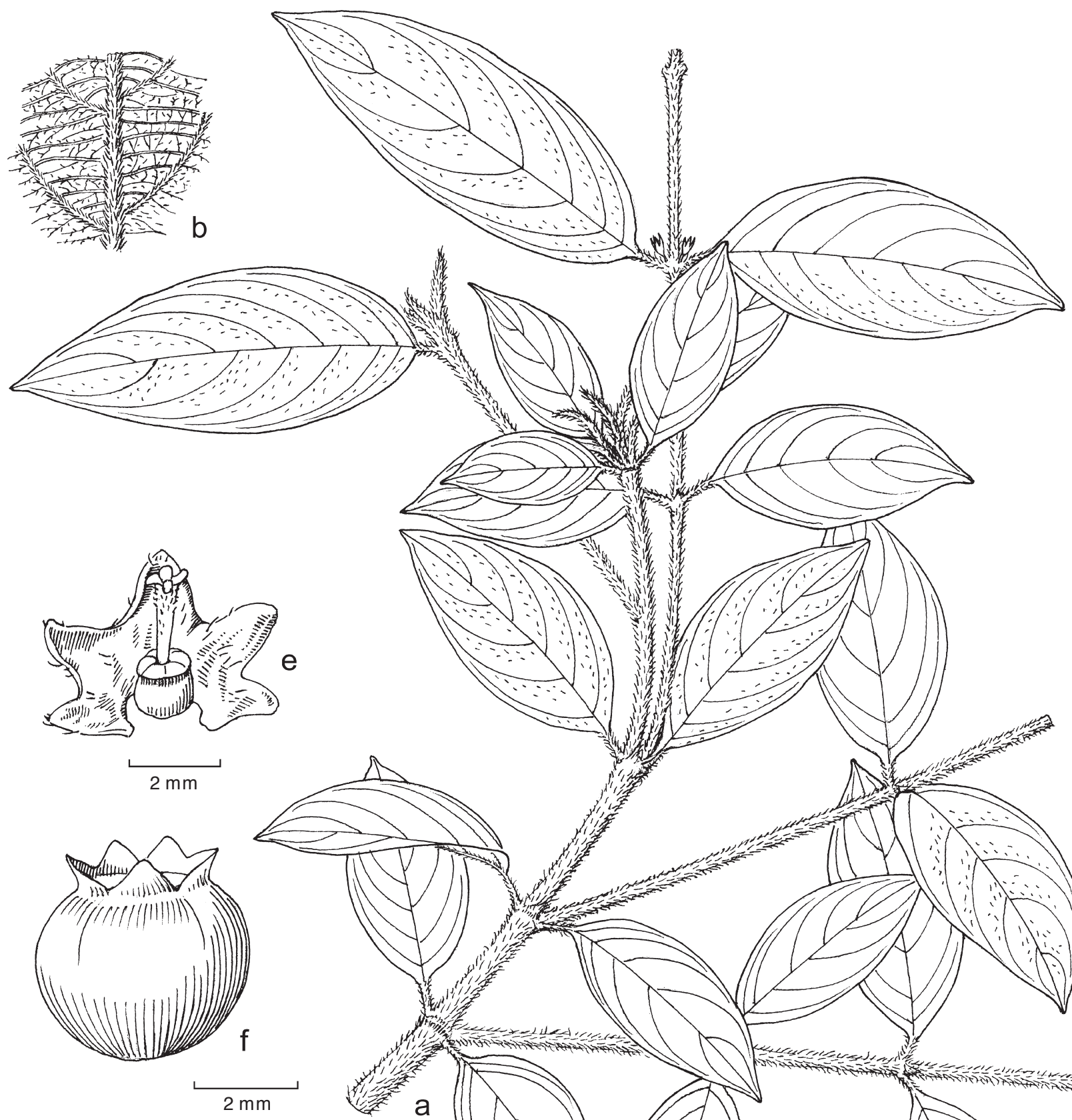

a

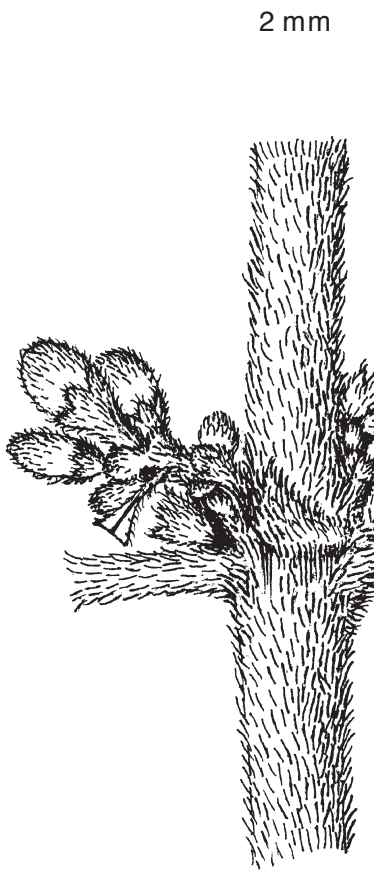

$\mathrm{C}$

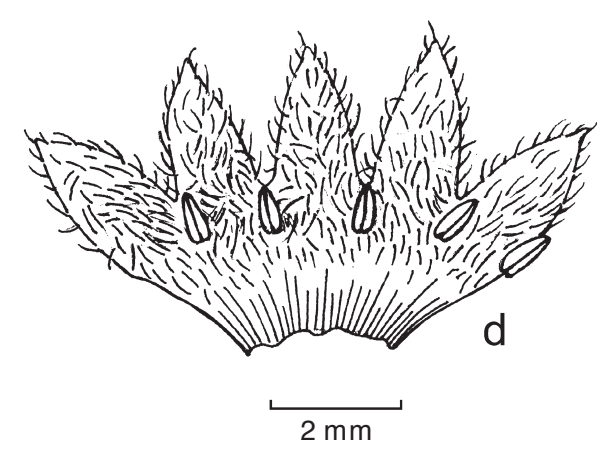

Fig. 6 Lasianthus brevipedunculatus H.Zhu. a. Habit; b. detail of lower surface of leaf showing indumentum and parallel nervules; c. detail of node showing stipule and axillary inflorescences; d. corolla split opened; e. calyx split opened; f. fruit (all: H. Nagamasu 3359, holo L). 


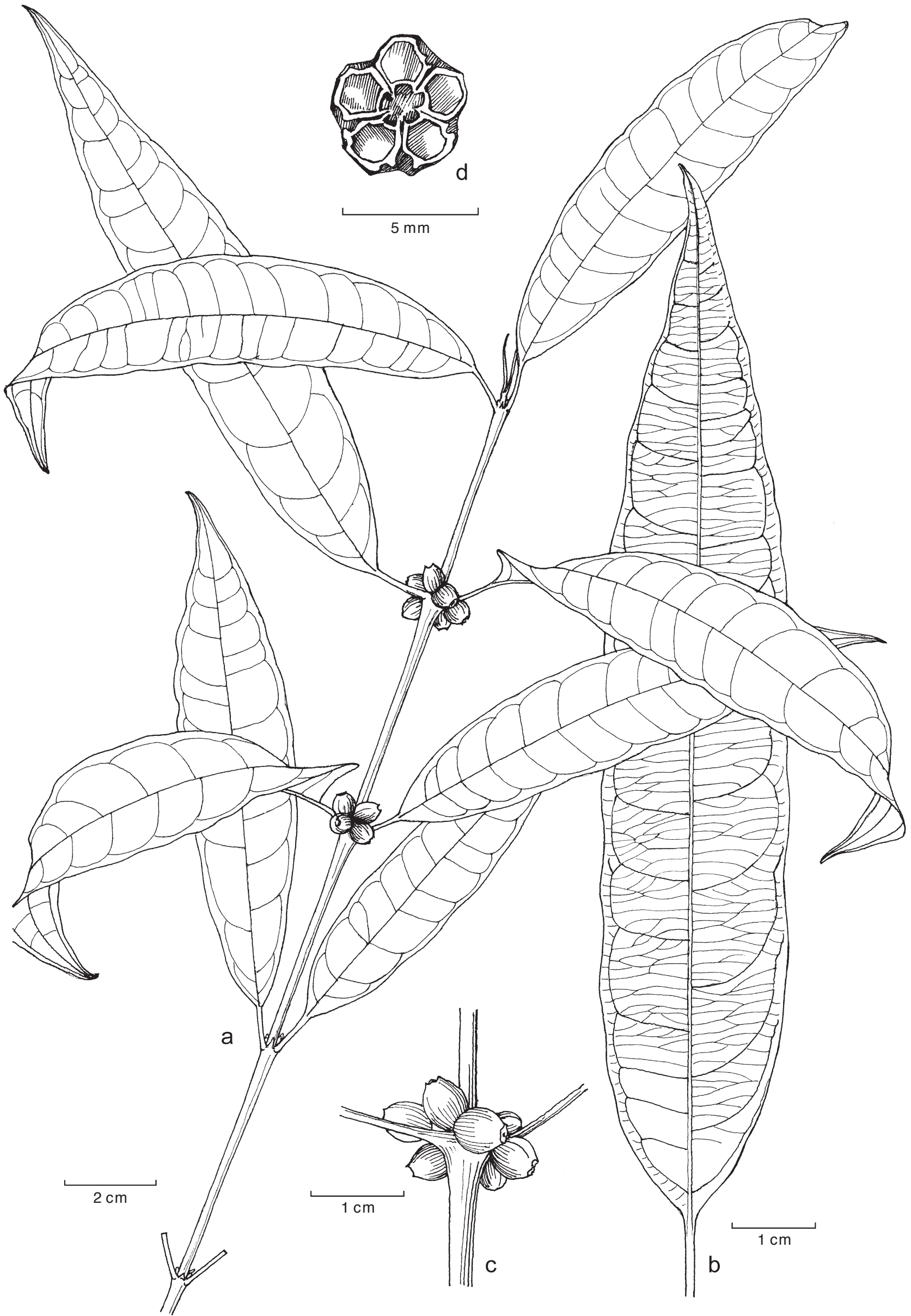

Fig. 7 Lasianthus brochidodromus H.Zhu. a. Habit with fruits; b. detail of leaf; c. detail of node showing axillary fruits; d. cross section of fruit (all: F. Gaerlan et al. PPI23712, holo L). 


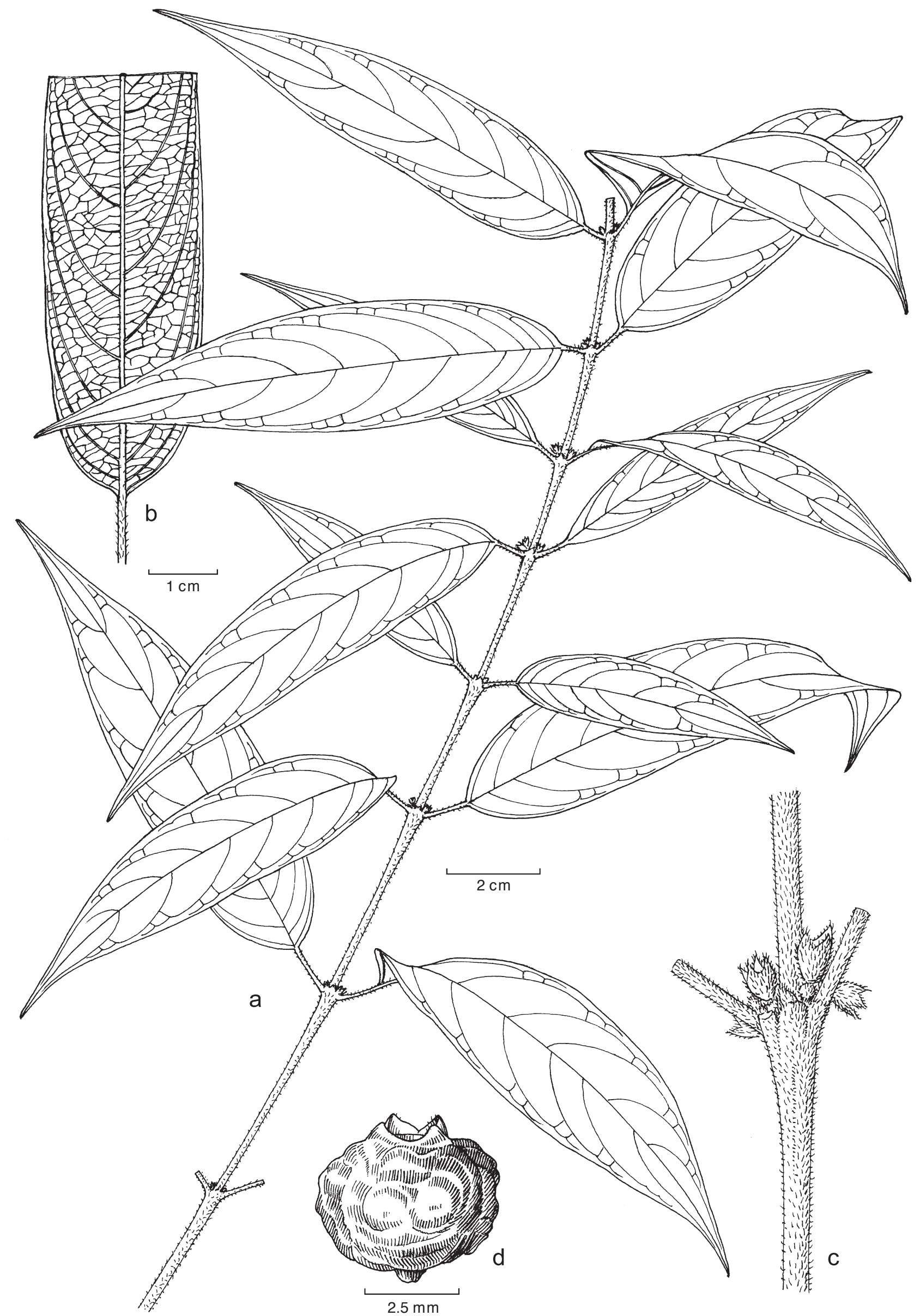

Fig. 8 Lasianthus bruneensis H.Zhu. a. Habit with inflorescences; b. lower surface of leaf showing reticulate nervules; c. detail of node showing stipule and axillary inflorescences; d. fruit (all: G.T. Prance et al. 30620, holo L). 
and joining the nerves above, forming an intramarginal vein (looped venation), internerved vein weak, ascending from the midrib at an angle of c. $90^{\circ}$, combination to the main nerves, nervules conspicuous on both surfaces, reticulate; petioles $1-1.5 \mathrm{~cm}$ long, dark, glabrous or sparsely pubescent. Stipules small, subulate, c. $1.5 \mathrm{~mm}$ long, pubescent. Inflorescences sessile; bracts absent. Flowers not seen. Drupes in fascicles, sessile, globose, c. $5 \mathrm{~mm}$ diam, puberulous, slightly warty, with 4-5 obtuse ridges, crowned by very small calyx teeth; pyrenes $4-5$, slightly warty on the abaxial face, orbicular in transverse section.

Distribution - Endemic in Alabat IsI., Quezon, Philippines. Habitat \& Ecology — In dipterocarp forest. Fruiting in March.

Note - This species is characterized by its lanceolate leaves with a looped venation. It seems to be close to L. membranaceoideus, but differs from the latter by having leaves lanceolate, $2-2.5 \mathrm{~cm}$ broad, drupes puberulous, c. $5 \mathrm{~mm}$ diam, with 4-5 obtuse ridges, pyrenes slightly warty on the abaxial face, orbicular in transverse section. Lasianthus membranaceoideus has leaves oblong, 3-4 cm broad, drupes glabrous, c. $7 \mathrm{~mm}$ diam, conspicuously 8-ridged, pyrenes sulcate on the abaxial face, triangular in transverse section.

\section{Lasianthus bruneensis H.Zhu, sp. nov. - Fig. 8}

Proximus $L$. subaureo Craib, sed foliis basi rotundatis conspicue asymmetricis, stipulis minoribus $1 \mathrm{~mm}$ longis atque calycibus dentatis differt. - Typus: Prance et al. 30620 (holo L; iso K), Brunei, Bukit Belalong, $909 \mathrm{~m}$ alt., in lower montane forest around summit, 23 Feb. 1992.

Treelet, $2 \mathrm{~m}$ high; branchlets terete, puberulous, glabrescent or glabrous. Leaves: blades linear-lanceolate to oblong-lanceolate, $8-14$ by $1.5-3 \mathrm{~cm}$, coriaceous, glabrous or sparsely puberulous on leaf nerves beneath, apex attenuate to acuminate or caudate, margin recurved, base rounded, asymmetric, midrib conspicuously prominent on both surfaces, nerves flat above, prominent beneath, $6-7$ pairs, ascending at an angle of $75-85^{\circ}$, curved to the margin, nervules conspicuous beneath, reticulate; petioles nigrescent, $1 \mathrm{~cm}$ long, sparsely puberulous. Stipules very small, triangular, $1 \mathrm{~mm}$ long, puberulous. Inflorescences sessile or short tuberculate, bracts inconspicuous. Flowers in fascicles sessile; calyx campanulate, 2 by $2 \mathrm{~mm}$, puberulous, limb with 5 subulate-triangular $0.5 \mathrm{~mm}$ long teeth; corolla not seen. Drupes c. $4 \mathrm{~mm}$ diam, subglobose, subglabrous, black, crowned by persistent small subulate-triangular calyx teeth; pyrenes $4-5$, slightly rugose on the abaxial face, triangular in transverse section, with thickened wall.

Distribution - Brunei.

Habitat \& Ecology - In lower montane forest between 800-1160 m altitude. In sandstone soil. Flowering and fruiting between October and February.

Additional specimens examined. Brunei, Bukit Tudal, Davis A.P. 481

Note - This species is close to $L$. subaureus. It differs from the latter by having leaves with rounded and asymmetric bases, very small stipules, calyx not cupular, calyx limb with subulatetriangular teeth. Lasianthus subaureus has leaves with acute to acuminate base, stipules $3 \mathrm{~mm}$ long, calyx cupular, with truncate limb.

\section{Lasianthus cailinianus H.Zhu, sp. nov. - Fig. 9}

Proximus L. chrysophyllo Miq., sed plantis dense patenter fulvi-hirsutis, foliis minoribus oblongis basi leviter asymmetricis, pedunculis cymae robustis 7-8 mm longis, bracteis minoribus apice brevicuspidatis, lobis calycis 5 , 2-3 mm longis et pyrenis 5 differt. Similis L. cyanocarpo Jack, sed plantis dense fulvi-hirsutis, foliis majoribus $10-17 \mathrm{~cm}$ longis basi abrupte acutis vel subrotundatis, nervis 14-binatis et pedunculis cymae robustis $7-8 \mathrm{~mm}$ longis differt. A L. hirsuto (Roxb.) Merr. plantis dense fulvi-hirsutis, foliis basi abrupte acutis vel subrotundatis, nervis 14-binatis, stipulis minoribus $3 \mathrm{~mm}$ longis et cymis pedunculatis differt. - Typus: Ismael 3/21.8.1957 (holo L), W Sumatra, east of Pajakumbuh, 500-1000 m alt., in primary forest, 21 Aug. 1957.

Shrub, c. $2.5 \mathrm{~m}$ high, branchlets terete, or slightly compressed in the youngest part, robust, c. 3-4 mm diam, densely spreading yellowish hirsute. Leaves: blades oblong, $10-17$ by $3-5$ $\mathrm{cm}$, thickly chartaceous, stiffly spreading yellowish hirsute on both surfaces, apex acute, base abruptly acute or subrounded, slightly asymmetric, midrib densely stiffly hirsute above, strongly prominent and densely hirsute beneath, nerves depressed above, strongly prominent beneath, densely hirsute, c. 14 pairs, ascending at an angle of c. $80^{\circ}$, curved gradually to margin, nervules obscure above, conspicuous beneath, subreticulate, hirsute, margin slightly recurved, densely hirsute; petioles 5-7 $\mathrm{mm}$ long, densely hirsute. Stipules lanceolate-triangular, c. 3 $\mathrm{mm}$ long, densely hirsute. Inflorescences pedunculate; peduncles 7-8 mm long, robust, densely yellowish hirsute; bracts 2 , leaf-like, ovate, c. 1.5 by $1 \mathrm{~cm}$, with shortly cuspidate apex and rounded or subcordate base, and with midrib and nerves like the leaves, densely yellowish hirsute on both surfaces; bracteoles numerous, outer ones like bracts but smaller, interior ones ovate to linear, c. $1 \mathrm{~cm}$ long, densely hirsute; calyx c. $4-5 \mathrm{~mm}$ long, densely hirsute, lobes 5 , lanceolate, $2-3 \mathrm{~mm}$ long, densely hirsute on both surfaces; corolla densely hirsute. Drupes c. 4 $\mathrm{mm}$ diam, subglobose, densely hirsute, crowned by persistent linear-lanceolate, c. $5 \mathrm{~mm}$ long, hirsute calyx lobes; pyrenes 5 .

Distribution - Indonesia (W Sumatra).

Habitat \& Ecology — In montane primary forest between 500-1000 m altitude.

Notes - This species is characterized by its densely spreading yellowish hirsute hairs, peduncled cymes with leaf-like bracts and bracteoles. It is closely related to $L$. chrysophyllus, but differs from the latter by having branchlets, leaves both surfaces densely spreading yellowish hirsute; leaves relatively small, oblong, with slightly asymmetric base, $10-17$ by $3-5$ $\mathrm{cm}$; peduncles $7-8 \mathrm{~mm}$ long, bracts relatively small with shortly cuspidate apex; flowers 5-merous; calyx lobes 5, 2-3 mm long. Lasianthus chrysophyllus has branchlets and leaf venation, bracts and calyx densely appressed-pubescent; leaves larger, slightly obovate-oblong, $26-34$ by $6-8 \mathrm{~cm}$; peduncles c. $2-3$ $\mathrm{mm}$ long; bracts larger, with a c. $5 \mathrm{~mm}$ long cuspidate apex; flowers 4-merous; calyx lobes 4, c. $1.5 \mathrm{~mm}$ long.

It is also related to $L$. cyanocarpus, but differs from the latter by having plants covered by densely yellowish hirsute, leaves relatively big (10-17 cm long) with abruptly acute to subrounded base and 14 pairs of nerves, cymes with $7-8 \mathrm{~mm}$ long robust peduncles. While $L$. cyanocarpus has much soft pilose hairs on branchlets, leaves and bracts; leaves relatively small (8-13 $\mathrm{cm}$ long) with rounded to cordate oblique base and less than 10 pairs of nerves; cymes sessile or subsessile. This species is also similar to $L$. hirsutus, but differs from the latter by having densely yellowish hirsute hairs, leaves with 14 pairs of nerves and abruptly acute or subrounded base, stipules $3 \mathrm{~mm}$ long, cymes peduncled. Lasianthus hirsutus has rusty hirsute hairs, leaves with 7-10 pairs of nerves and acute to cuneate base, stipules 8-10 mm long, and cymes sessile.

\section{Lasianthus capitatus Blume}

Lasianthus capitatus Blume (1826-1827) 996; Miq. (1857) 320; (1869) 246 Merr. (1921) 577; Bakh.f. (1965) 337. - Mephitidia capitata (Blume) DC. (1830) 453. - Type: Blume s.n. p.p. (the part from Java, non Sumatra) (lecto L, designated here, barcode L0310036), Java.

Shrubs; branchlets terete, c. $3 \mathrm{~mm}$ diam, densely tomentose. Leaves: blades oblong-elliptic to oblong-lanceolate, $10-15$ by $3-3.5 \mathrm{~cm}$, coriaceous, glabrous above, tomentose beneath, apex acuminate, base acute or cuneate, midrib and nerves flat 


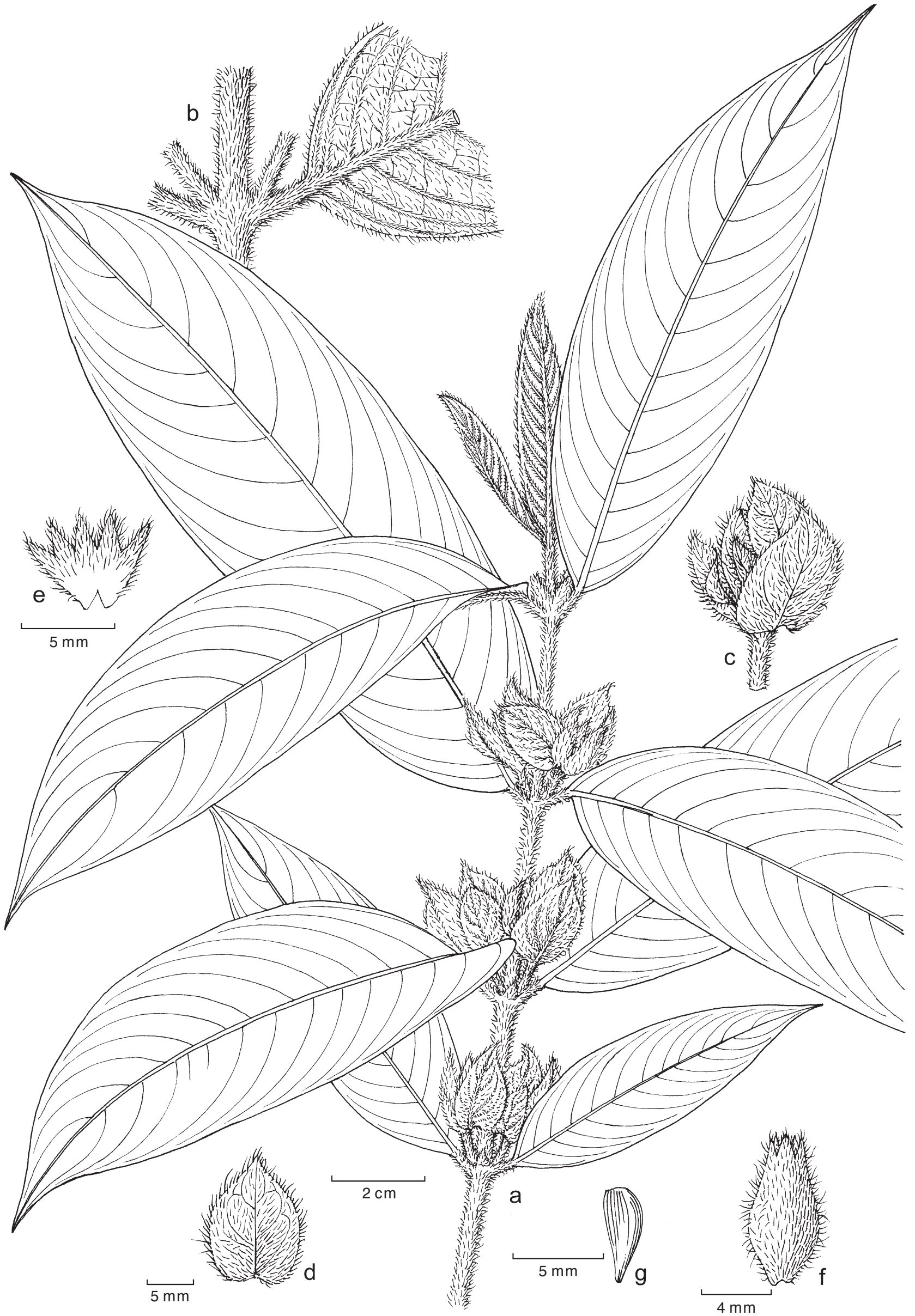

Fig. 9 Lasianthus cailinianus H.Zhu. a. Habit with inflorescences; b. detail of node showing indumentum of branch and lower surface of leaf; c. detail of inflorescence; d. bract; e. calyx split opened; f. fruit; g. pyrene in lateral view (all: Ismael no. 3/21.8.1957, holo L). 
or slightly depressed above, prominent beneath, nerves 7-8 pairs, ascending at an angle of $40-50^{\circ}$, curved to the margin, nervules obscure above, slightly prominent beneath, parallel; petioles 5-8 $\mathrm{mm}$ long, densely tomentose. Stipules narrowly triangular, c. $3 \mathrm{~mm}$ long, densely tomentose. Cymes pedunculate; peduncles $0.2-2 \mathrm{~cm}$ long, stout, densely tomentose; bracts linear, $0.5-1 \mathrm{~cm}$ long, densely tomentose. Flowers sessile; calyx densely long-villose, tube 1-2 mm long, lobes 6 , linear, up to $12 \mathrm{~mm}$ long; corolla tube c. $10 \mathrm{~mm}$ long, long-villose outside, lobes 6 , ovate-triangular, c. $3 \mathrm{~mm}$ long, long-villose outside, floccose inside. Drupes subglobose, c. $8 \mathrm{~mm}$ diam, densely tomentose, crowned by persistent linear calyx lobes; pyrenes 6 .

Distribution - Indonesia (Java and Lesser Sunda Islands).

Notes - The herbarium sheet with barcode L0310036 is a mixture containing two distinct species respectively from Java and Sumatra; the lectotype of $L$. capitatus is the one from Java.

Lasianthus capitatus is similar to $L$. chevalieri from mainland SE Asia. It differs in having pedunculate cymes, 7-8 pairs of nerves, conspicuously villose linear bracts and relatively small flowers. Lasianthus chevalieri has sessile and ebracteate cymes, 11 pairs of nerves, relatively large flowers with the calyx tube 5-6 mm long, the calyx lobes $13-14 \mathrm{~mm}$ long, the corolla tube $13 \mathrm{~mm}$ long and the corolla lobes c. $8 \mathrm{~mm}$ long.

Lasianthus capitatus has peduncles, which vary from almost subsessile to $1-2 \mathrm{~cm}$ long even in the same specimen. The inferior peduncles are usually longer and the superior ones are shorter. A variety of short peduncles cannot be clearly recognized (e.g. var. sessilis Blume in sheets and var. subsessilis Miq. in sheets).

\section{Lasianthus chinensis (Champ.) Benth. - Map 4}

Lasianthus chinensis (Champ.) Benth. (1861) 160; Hook.f. (1880) 187; F.B. Forbes \& HemsI. (1888) 388; T.Yamaz. (1964) 352; T.S.Liu \& J.M.Chao (1964) 124, f. 4; J.M.Chao (1978) 286; H.Zhu (1994) 67; H.J.Li \& H.Y.Liu (1998) 280; H.S.Lo (1999) 84, pl. 22: 1-5; H.Zhu (2001b) 123; (2002) 88. - Mephitidia chinensis Champ. (1852) 196. - Type (): Champion? 112 (lecto K; isolecto NY, designated by Zhu 2001b), Hongkong; Champion s.n. (para K), Hongkong.

Lasianthus dinhensis Pierre ex Pit. (1924) 388. - Syntypes: Poilane 283 (P), Cambodge [Cambodia], Kampot; Pierre 3257 (BM, K, MO, P), Cochinchina [Vietnam], Baria.

Lasianthus dinhensis Pierre ex Pit. var. tonkinensis Pit. (1924) 388. - Syntypes: Balansa 640 (K, P), Vietnam: Tonkin, Ouonbi; Laos: Poilane 2327 $(\mathrm{BM}, \mathrm{K}, \mathrm{P})$, Tranninh.
Lasianthus dinhensis Pierre ex Pit. var. glabrescens Pierre ex Pit. (1924) 388. - Type: Pierre 3258 (holo P), Cochinchina [Vietnam].

Mephitidia odajimae Masam. (1934) 211. — Lasianthus chinensis (Champ.) Benth. var. odajimae (Masam.) Kaneh. (1936) 669. - Type not designated.

Shrubs, 1-4 m tall; branches and branchlets terete, densely pubescent. Leaves: blades subcoriaceous, oblong, 15-25 by 4-7 cm, apex acute or acuminate, base acute or obtuse, margin usually reflexed, glabrous above, thinly to densely pubescent beneath, midrib and nerves flat above, prominent beneath, nerves $9-15$ pairs, ascending at an angle of $60-70^{\circ}$, curved to the margin, nervules distinct above, distinct and prominent beneath, reticulate; petioles $1-1.5 \mathrm{~cm}$ long, pubescent. Stipules triangular, 2-3 mm long, pubescent. Cymes sessile; bracts absent; 4-6-flowered. Flowers sessile; calyx elongated campanulate, 5-7 mm long, with 4-6 triangular-ovate or orbicular reflexed lobes; corolla white, $10-15 \mathrm{~mm}$ long, hirsute outside, lobes 5-6, lanceolate. Drupes pubescent, $8 \mathrm{~mm}$ diam, with 5-6 conspicuous longitudinal angles; pyrenes 5-6.

Distribution - China, Vietnam, Laos, Cambodia, Thailand, Peninsular Malaysia, Philippines (Palawan).

Note - Lasianthus chinensis is easily confused with L. verticillatus. This confusion has occurred in many references. According to Bentham's (1861) original description of $L$. chinensis, it has leaves with parallel nervules conspicuous on both sides and diverging from the midrib, but the type specimen has almost reticulate nervules. This may be a factor leading to the confusion. Lasianthus chinensis usually has dense pubescence on branches and leaf nerves beneath, chartaceous or subcoriaceous leaves with $10-13(-15)$ pairs of nerves, and reticulate nervules as well as reflexed margins, calyx with triangular, ovate or orbicular reflexed lobes, and drupes with 5-6 conspicuous longitudinal angles; while $L$. verticillatus has thin or sparse appressed-pubescence on branches and leaf nerves beneath, coriaceous leaves with 5-9 pairs of nerves and parallel nervules, and a cupulate, usually truncate or sometime minutely toothed calyx, and smooth and rounded drupes.

\section{Lasianthus chlorocarpus K.Schum.}

Lasianthus chlorocarpus K.Schum. (1905) 399; Valeton (1927) 109; Merr. \& L.M.Perry (1946) 219. - Type: Lauterbach 3151 (B十), New Guinea; Wiakabu et al. LAE 50043 (neotype L, designated here), New Guinea, Vanimo sub Province, 140 m alt., in rainforest, 5 Sept. 1982.

Lasianthus chlorocarpus K.Schum. var. curvinervis Valeton (1927) 110, syn. nov. - Type: Ledermann 6630 (lecto SING, designated here), New Guinea.

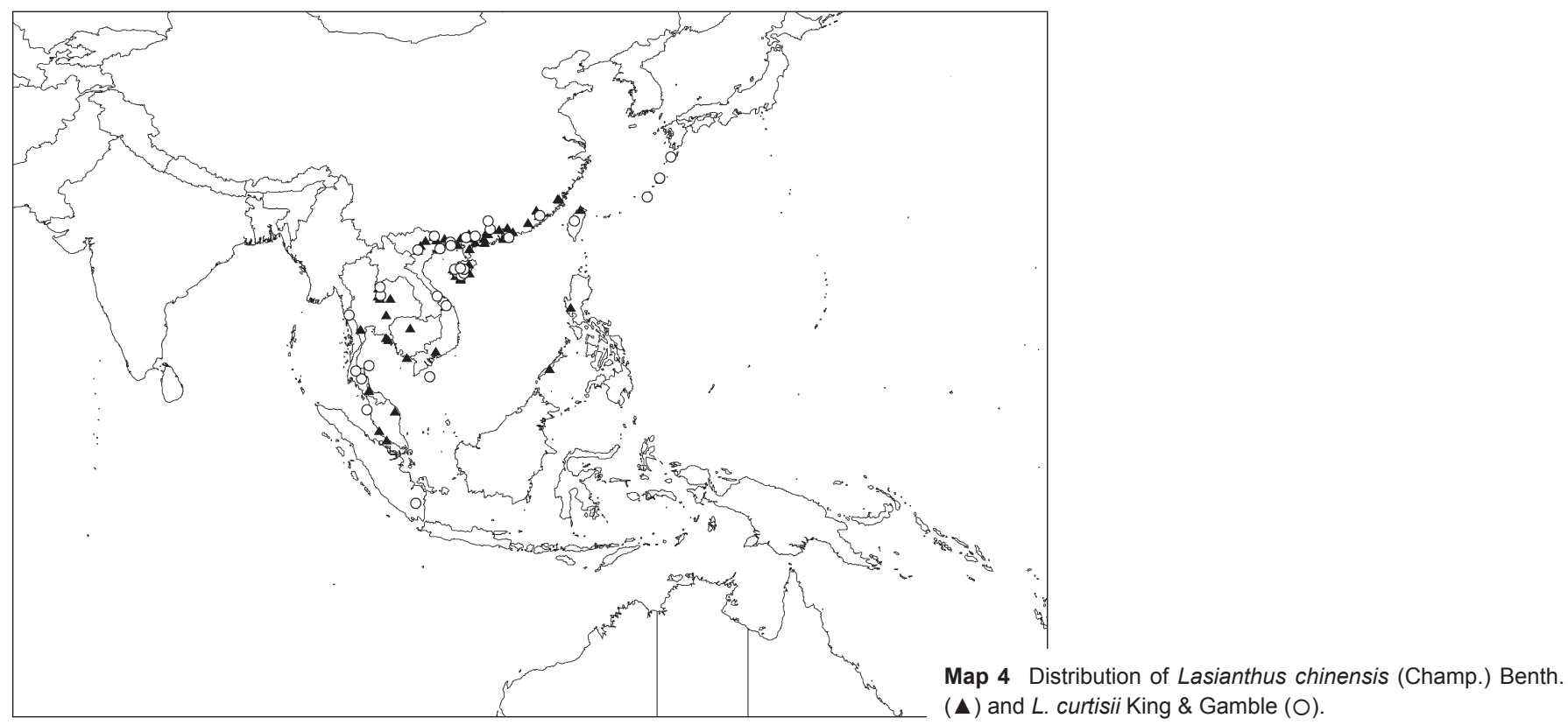

$(\Delta)$ and L. curtisii King \& Gamble (O). 
Shrubs, c. $2 \mathrm{~m}$ high; branchlets terete, c. $2 \mathrm{~mm}$ diam, slightly compressed in the youngest part, sparsely spreading hirsute (strigillose), brown when dry. Leaves: blades oblong-lanceolate, $10-18$ by $3-5 \mathrm{~cm}$, chartaceous, glabrous above, hirsute on venation beneath, apex acute to cuspidate, base acute or cuneate, slightly asymmetric, midrib and nerves flat above, prominent beneath, nerves 7 pairs, ascending at an angle of c. $50^{\circ}$, curved to the margin, nervules obscure above, distinct and slightly prominent beneath, subreticulate; petioles 5-10 $\mathrm{mm}$ long, spreading hirsute. Stipules subulate, 4-5 mm long, hirsute. Cymes sessile; bracts absent. Flowers sessile; calyx campanulate, spreading hirsute, tube c. $2 \mathrm{~mm}$ long, limb c. $1.5 \mathrm{~mm}$ long, with 4 minute teeth; corolla tube c. $5 \mathrm{~mm}$ long, glabrous in the lower half on both sides, hirsute in the upper half on both sides, corolla lobes 4 , lanceolate, c. $3 \mathrm{~mm}$ long, hirsute outside, floccose inside. Drupes ellipsoid, c. $5 \mathrm{~mm}$ diam, sparsely hirsute, verrucose, with 4 obscure ridges; pyrenes 4 .

Distribution - Philippines, Indonesia (Lesser Sunda Islands, Sulawesi, Irian Jaya) Papua New Guinea, Solomon Isl., N Australia.

Notes - This species is very close to $L$. trichophlebus. Both species have strigillose hairs on young branches, leaves nerves beneath, stipules and calyx. Lasianthus chlorocarpus differs from $L$. trichophlebus by having subulate stipules and thinner chartaceous leaves with subreticulate nervules and relatively short strigose and minutely teethed calyx limb; while the latter has coriaceous to subcoriaceous leaves, lanceolate-triangular calyx lobes, lanceolate stipules that are more than $5 \mathrm{~mm}$ long, and much long and spreading strigose hairs.

This species is also close to $L$. verticillatus. It differs from the latter by having relatively long subulate stipules (up to $5 \mathrm{~mm}$ long); chartaceous leaves with subreticulate nervules; strigillose hairs on branches, nerves beneath, stipules and calyx; as well as usually slightly verrucose drupes with 4 pyrenes and without an enlarged cupular and truncate calyx limb. Lasianthus verticillatus usually has triangular stipules, subcoriaceous to coriaceous leaves, parallel nervules and glabrous or appressedpuberulous on branches, nerves beneath, stipules and calyx, and usually drupes with 5 pyrenes and crowned by an enlarged cupular calyx limb with truncate apex.

Valeton (1927) and Merrill \& Perry (1946) mentioned that L. chlorocarpus could be L. strigosus Wight from Australia. We agree that $L$. chlorocarpus is conspecific to $L$. strigosus auct. plur. (non Wight) from Australia.

Schlechter 18625 (K), a syntype of L. chlorocarpus K.Schum. var. curvinervis Valeton, is closer to $L$. verticillatus than to $L$. chlorocarpus and therefore excluded from $L$. chlorocarpus.

\section{Lasianthus chryseus Ridl.}

Lasianthus chryseus Ridl. (1920) 143; (1923a) 158. — Lectotype (here designated) Ridley 140 (lecto K), Singapore; Curtis s.n. (para, n.v.), Peninsular Malaysia, Penang.

Mephitidia capitata (Blume) DC. var. ferruginea Korth. (1851) 222, syn. nov. - Type: Korthals s.n. (iso L, barcode L0057527), Borneo, Prarawin. Lasianthus kurzii auct. non Hook.f.: King \& Gamble (1904) 119.

Shrubs, 1.2-2 m high; branchlets terete, c. $2.5 \mathrm{~mm}$ diam, densely brown-tomentose. Leaves: blades elliptic-oblong to oblong-lanceolate, $9-15$ by $3-5 \mathrm{~cm}$, thinly coriaceous, glabrous and nitid above, densely brown-tomentose beneath, apex acute, base acute or cuneate, midrib and nerves flat or slightly depressed above, strongly prominent beneath, nerves $6-8$ pairs, ascending at an angle of c. $50^{\circ}$, curved to the margin, nervules distinct above, distinct and prominent beneath, densely anastomosing, parallel; petioles c. $1 \mathrm{~cm}$ long, densely brown-tomentose. Stipules triangular-lanceolate, c. 2 mm long, densely brown-tomentose. Cymes sessile; bracts very small, subulate, c. $1 \mathrm{~mm}$ long, densely tomentose. Flowers sessile; calyx campanulate, densely tomentose outside, calyx tube c. $1 \mathrm{~mm}$ long, limb with 4-5 triangular lobes, densely tomentose outside, glabrous and dark in colour inside, lobes c. $1 \mathrm{~mm}$ long; corolla c. $5 \mathrm{~mm}$ long, densely tomentose outside. Drupes globose, 4-5 mm diam, sparsely hairy or glabrous except the upper part, obscurely 4-5-ridged; pyrenes $4-5$, smooth on the abaxial face.

Distribution - Malaysia (Peninsular, Borneo), Brunei, Indonesia (Kalimantan).

Notes - Lasianthus chryseus differs from L. trichophlebus var. latifolius by having denser tomentose branchlets and leaves beneath, midrib and nerves strongly prominent beneath, nervules also more prominent beneath, small and inconspicuous stipules, subulate bracts and much smooth drupes (non verrucose) with $4-5$ pyrenes. It differs from $L$. obscurus in having small stipules and minutely subulate bracts, and subglabrous drupes except hirsute hairs on upper part.

The type specimen of $L$. capitatus var. ferruginea Korth. differs from $L$. capitatus var. capitatus by having ferruginous-tomentose branchlets and leaves beneath, and almost no peduncles, just as $L$. chryseus.

\section{Lasianthus chrysoneurus (Korth.) Miq. - Map 5}

Lasianthus chrysoneurus (Korth.) Miq. (1857) 322; H.Zhu (2002) 81. — Mephitidia chrysoneura Korth. (1851) 222. - Type: Korthals s.n. (lost), Java, Patoea; Backer 22515 (neotype L, designated by Zhu 2002) Java, Jawa Barat, Tjadasmalang.

Lasianthus glabrescens Miq. (1857) 317, syn. nov. - Type: Zollinger 621 $(=594)$ (holo L; iso K), Java.

Lasianthus kurzii Hook.f. (1880) 183; Pit. (1924) 384; Craib (1934) 212; Deb \& M.Gangop. (1991) 288; H.Zhu (1994) 60; (1998) 153; H.S.Lo (1999) 90; H.Zhu (2001b) 133. - Type: Wall. Cat. 8310 (holo K), Burma, Chopedang. Lasianthus hoaensis Pierre ex Pit. (1924) 383. - Syntypes: Pierre 1316 (P; isosyn BM, E, K), Cochinchina, Bien Hoa, Tri-huyen; Poilane 40832 (P; isosyn BM), Bien Hoa, Gia-ray; Pierre 3267 (P), Cambodia, Mt Camchay, Kampot.

Lasianthus kurzii Hook.f. var. howii H.S.Lo (1993) 2; (1999) 90. — Type: Wang 80524 (holo SCBI), China, Yunnan, Mengla.

[Lasianthus stercorarius auct. non Blume: Kurz (1877) 31].

Shrubs, to $3 \mathrm{~m}$ tall; branchlets appressed-pubescent. Leaves: blades elliptic-oblong to elliptic-lanceolate, $12-20$ by $3-5 \mathrm{~cm}$, apex acuminate, base cuneate, membranaceous, glabrous above, appressed-pubescent beneath, midrib and nerves slightly prominent above, prominent beneath, nerves 7-10 pairs, ascending at an angle of $50-60^{\circ}$, curved to the margin, nervules slightly distinct on both surfaces, dense, parallel; petioles 5-10 $\mathrm{mm}$ long, appressed-pubescent. Stipules triangular or oblonglanceolate, up to $8 \mathrm{~mm}$ long, pubescent. Cymes sessile; bracts persistent, outer bracts ovate, inner bracts lanceolate, all not more than $5 \mathrm{~mm}$ long, pubescent. Flowers sessile or subsessile; calyx campanulate, $2-3 \mathrm{~mm}$ long, pubescent; lobes triangular, 4-6; corolla 5-6 mm long, puberulous outside in upper part, pubescent inside in the throat. Drupes subglobose, 4-6 mm diam, pubescent; pyrenes 5-6.

Distribution - India, Burma, China (S Yunnan), Vietnam, Laos, Cambodia, Thailand, Indonesia (Java) and Papua New Guinea.

Note - We have not seen the type of $L$. chrysoneurus in $\mathrm{L}$, even Miquel himself had not seen it as he indicated when he made the combination, although the type should be in Leiden. However, there are some specimens from Java in $L$ which match Korthals' description of $L$. chrysoneurus well. Lasianthus glabrescens is conspecific with $L$. chrysoneurus. Lasianthus kurzii from mainland SE Asia, which has the same characteristics on leaves, stipules, bracts and flowers as 


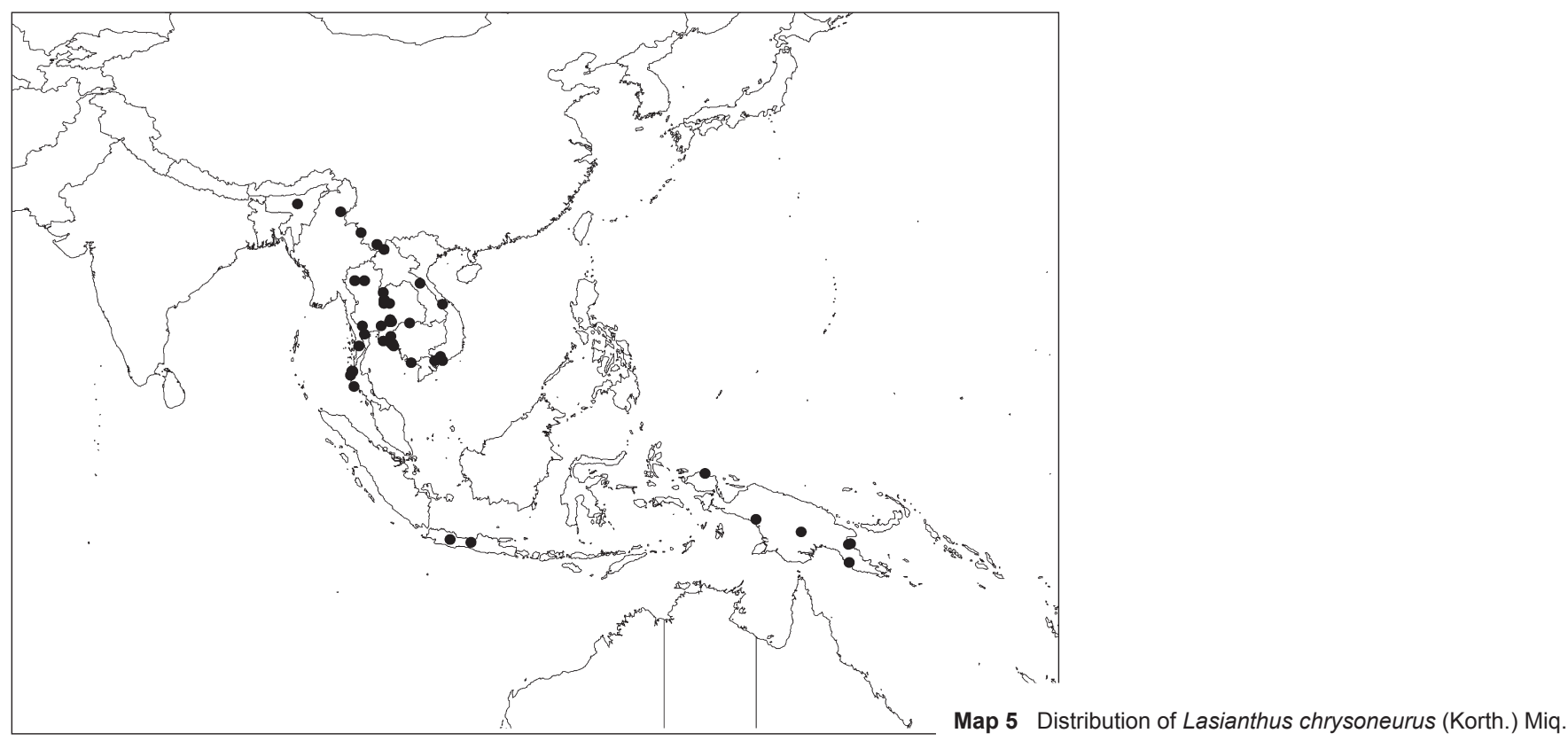

L. chrysoneurus, could not be separated from L. chrysoneurus; it is also conspecific with the latter. Lasianthus chrysoneurus differs from $L$. obscurus by different indumentum.

\section{Lasianthus chrysophyllus Miq.}

Lasianthus chrysophyllus Miq. (1857) 322; (1869) 248. - Type: Junghuhn s.n. (holo L, barcode L000676; iso L, barcode L000677), Sumatra.

Shrubs or treelet; branchlets robust, slightly compressed, c. 4-5 mm diam, fistulose, densely brown-appressed-pubescent. Leaves: blades oblong-lanceolate or oblong-oblanceolate, $26-34$ by $6-8 \mathrm{~cm}$, thinly coriaceous, glabrous above except hirsute midrib, brown-golden-pubescent beneath, apex cuspidate to shortly caudate, base acute to subrounded, asymmetric, the margin reflexed, nerves slightly depressed above, prominent beneath, $13-15$ pairs, ascending at an angle of $60-70^{\circ}$, curved to margin, nervules slightly obscure above, distinct and prominent beneath, reticulate; petioles $1-1.5 \mathrm{~cm}$ long densely appressed-pubescent. Stipules triangular, 8-9 $\mathrm{mm}$ long, densely appressed-pubescent. Cymes pedunculate; peduncles 2-5 mm long, robust, densely appressed-pubescent; bracts leaf-like, outer pairs rounded, palmate-nerved, c. 2 by 2 $\mathrm{cm}$, golden-pubescent on both surfaces, ciliate at the margin, with a cuspidate-caudate apex and a rounded to subcordate base, inner ones becoming smaller, from leaf-like to ovate and lanceolate, golden-pubescent on both surfaces. Flowers 4-merous, sessile; calyx obconical, c. $4-5 \mathrm{~mm}$ long, tube c. 1.5 $\mathrm{mm}$ long, glabrous, limb densely hirsute with 4 lanceolate $\mathrm{c}$. $1.5 \mathrm{~mm}$ long lobes; corolla c. $15 \mathrm{~mm}$ long, tube glabrous in the lower half, lobes 4 , triangular-lanceolate, c. $2.5 \mathrm{~mm}$ long, hirsute outside. Drupes subglobose, c. 3-4 mm diam, glabrous except the hirsute persistent calyx limb, slightly verrucose; pyrenes 4 .

Distribution - Indonesia (Sumatra).

\section{Lasianthus chrysotrichus Lauterb.}

Lasianthus chrysotrichus Lauterb. (1905) 400; Valeton (1911) 497; (1927) 109. - Type: Schlechter 14376 (WRSL?, n.v.), New Guinea.

Shrubs, up to $3 \mathrm{~m}$ high; branchlets terete, c. $2 \mathrm{~mm}$ diam, densely and coarsely spreading hirsute. Leaves: blades oblonglanceolate, $5-8$ by $2-2.5 \mathrm{~cm}$, chartaceous to subcoriaceous, glabrous above except spreading hirsute hairs on midrib, densely hirsute on midrib and nerves beneath, apex acute, base acute to subrounded, rarely asymmetric, nerves flat or slightly depressed above, prominent beneath, $6-8$ pairs, ascending at an angle of c. $50^{\circ}$, curved to the margin, nervules obscure above, distinct beneath, subparallel; petioles $4-5 \mathrm{~mm}$ long, densely spreading hirsute. Stipules inconspicuous, triangular, c. 1-1.5 mm long, densely hirsute. Cymes sessile; bracts linear, fewer, 3-6 mm long, densely hirsute. Flowers sessile; calyx campanulate, c. $5 \mathrm{~mm}$ long, hirsute outside, tube c. $1.5-2 \mathrm{~mm}$ long, lobes 4, lanceolate, nerved, c. $3 \mathrm{~mm}$ long, hirsute outside, glabrous inside; corolla tube c. $4 \mathrm{~mm}$ long, hirsute in the upper half, lobes 4, c. 1.5-2 mm long, hirsute outside. Drupes subglobose, c. 4-5 mm diam, hirsute, crowned by lanceolate calyx lobes; pyrenes 4 .

Distribution - Papua New Guinea.

Notes - This species is close to $L$. curtisii by having similar linear-lanceolate calyx lobes (much longer than tube). It differs from the latter by having spreading much coarsely hirsute hairs on branchlets, leaf lower surface and midrib above; bracts 2 , linear, hirsute, up $6 \mathrm{~mm}$ long (only seen in fruit stage, inconspicuous in flower stage); flowers 4-merous and drupe with 4 pyrenes. Lasianthus curtisii has spreading villose hairs on branchlets and leaf lower surface; bracts absent; flowers 5-merous and drupe with 5 pyrenes. It is also similar to $L$. hexandrus, but differs in having spreading hirsute hairs on branches and leaves nerves beneath, bracts 2 , linear, up to c. $6 \mathrm{~mm}$ long (only seen in fruit stage); while $L$. hexandrus has appressedpubescent branchlets and leaf nerves beneath, bracts absent. Valeton published a name Lasianthus chrysotrichoides Valeton in his Key to species of New Guinean Lasianthus without description. We saw a specimen in Leiden, i.e. H.J.Lam 975 with Valeton's handwriting on attached labels (two sheets). This plant cannot be separated from $L$. chrysotrichus.

\section{Lasianthus clementis Merr.}

Lasianthus clementis Merr. (1908b) 164; Elmer (1911) 1034; (1913) 1869; Merr. (1923) 565. - Syntypes: Clemens 561 (PNH†), 846 (PNH†), Philippines, Mindanao, Leyte. Neotype: Elmer 13613 (K, designated here), Philippines, Mindanao, Agusan, Cabadbaran

Lasianthus canephoroides Wernham (1918) 73. - Type: Forbes 203 (holo BM), New Guinea, Sogere, $2000 \mathrm{ft}$, syn. nov.

Lasianthus bulusanensis Elmer (1934a) 3252. - Type: Elmer 16532 (iso L, U), Philippines, Luzon, Sorsogon, Mt Bulusan, syn. nov.

Lasianthus neglectus Valeton ex Bakh.f. (1963) 63, Bakh.f. (1965) 343, syn. nov. - Type: Backer 4915 (holo L), W Java, Mt Tjerimai, 1500 m alt. 
Shrubs, 1-1.5 m tall; branches and branchlets densely appressed-pubescent. Leaves: blades elliptic, oblong or ovate-oblong, $7-10$ by $3-5 \mathrm{~cm}$, subcoriaceous to chartaceous, glabrous above, densely appressed-pubescent on midrib and nerves beneath, apex cuspidate-acuminate or acuminate, base acute or obtuse, midrib and nerves flat or slightly depressed above, prominent beneath, nerves 4-6 pairs, ascending at an angle of c. $60^{\circ}$, curved to the margin, nervules subparallel, slightly prominent beneath; petioles 3-7 mm long, appressed-pubescent. Stipules minute, subulate, c. $1 \mathrm{~mm}$ long, appressed-pubescent. Cymes sessile; bracts absent. Flowers sessile, clusters; calyx campanulate, $1.5 \mathrm{~mm}$ long, appressed-pubescent, with 5 minute and triangular or subulate teeth; corolla white, $6-7 \mathrm{~mm}$ long, 5-lobed, pilose outside, villous inside. Drupes globose, pubescent or subglabrous, 3-6 mm diam; pyrenes 5.

Distribution - Philippines (Mindanao, Negros, Luzon), Indonesia (Sumatra, Java, Lesser Sunda Islands, Sulawesi, Moluccas), New Guinea

Notes - The type of L. clementis was not seen, but several specimens from the Philippines which are indicated as L. clementis, including the ones determined by Merrill himself, match Merrill's description well. The species is acceptable and consequently one of these collections from Mindanao of the Philippines, from the same place as the syntypes, was selected as a neotype. Lasianthus clementis is hardly distinguished from $L$. canephoroides from New Guinea and $L$. neglectus from Java. They are conspecific.

According to Elmer, L. bulusanensis differs from L. clementis by having leaves with caudate apex and acute base, which are just the same as those from Java (= L. neglectus). This is not enough to separate it from $L$. clementis.

Lasianthus clementis is very closely related $L$. hispidulus from mainland SE Asia, Sumatra and Borneo. It is separated from $L$. hispidulus in having more or less appressed hairs on branchlets, leaves beneath and calyx, and drupes appressed-pubescent or subglabrous. Lasianthus hispidulus has a dense covering of spreading hairs on branchlets, leaves beneath, calyx, and drupes. Both $L$. hispidulus and $L$. clementis have close affinity to $L$. fordii. They differ from $L$. fordii in having densely hairy branches, leaves beneath and calyx. The three taxa form a species complex or a complex species.

\section{Lasianthus congesticymus H.Zhu}

Lasianthus congesticymus H.Zhu (2001b) 124, f. 1. - Type: Larsen et al. 45955 (holo AAU), Thailand, Nakhon Srithamathat, Khao Luang, evergreen montane forest, $700-1200 \mathrm{~m}$ alt.

Shrubs; branchlets compressed when young, later terete, brown, subglabrous. Leaves: blades elliptic, $12-19$ by $3.5-6.5 \mathrm{~cm}$, chartaceous, more or less brown, glabrous, apex acuminate or subcaudate, base cuneate or rounded, slightly unequal sides, midrib conspicuous above, prominent beneath, nerves 6-7 pairs, conspicuous above, slightly prominent beneath, nervules conspicuous on both surfaces, subparallel; petioles $8-10 \mathrm{~mm}$ long, subglabrous. Stipules triangular, acute at apex, c. $1.5 \mathrm{~mm}$ long. Cymes pedunculate, strongly reduced; bracts absent. Flowers subsessile; calyx $2 \mathrm{~mm}$ long, limb more or less constricted at the base, lobes 4, triangular, c. $1 \mathrm{~mm}$ long, sparsely puberulous external surface; corolla $10 \mathrm{~mm}$ long, puberulous on upper part outside, lobes 5, with pilose outside. Drupes ellipsoid, $5 \mathrm{~mm}$ long, rugose, narrowed at the base, crowned by the persistent calyx limb; pyrenes 4 , very furrowed on the abaxial face.

Distribution — Thailand (Peninsular) and Malaysia (Borneo).

\section{Lasianthus conspicuus Ridl.}

Lasianthus conspicuus Ridl. (1909) 36; (1923a) 167; Craib (1934) 209; K.M. Wong (1989) 369; H.Zhu (2001b) 124. - Type: Ridley 13628 (holo SING; iso $\mathrm{K})$, Peninsular Malaysia, Pahang.

Shrubs, glabrous; branchlets terete, black when dry. Leaves: blades oblong-lanceolate, $12-17$ by $3-5 \mathrm{~cm}$, chartaceous, apex caudate, base broadly cuneate to subrounded, midrib, nerves and nervules conspicuous above, prominent beneath, nerves $8-9$ pairs, ascending at an angle of $70-80^{\circ}$, curved to the margin, nervules reticulate; petioles short, c. 3-5 $\mathrm{mm}$ long. Stipules small, triangular. Cymes sessile; bracts minute, linear, glabrous. Flowers sessile; calyx campanulate, limb cupular, with 5 minute teeth; corolla glabrous except the mouth, lobes 5 , nearly half as long as tube. Drupes small, ovoid, crowned by 5 -toothed calyx; pyrenes 5 .

Distribution - Thailand and Peninsular Malaysia.

\section{Lasianthus constrictus Wight}

Lasianthus constrictus Wight (1846) 515; Kurz (1877) 31; Hook.f. (1880) 188; King \& Gamble (1904) 117; Merr. (1921) 577; Ridl. (1923a) 163; Craib (1934) 209; Bakh.f. (1965) 342; K.M.Wong (1989) 369; H.Zhu (2001b) 124. - Type: Griffith s.n. (holo K), Burma.

Lasianthus constrictus Wight var. latifolius Craib (1934) 209. — Type: Kerr 14940 (holo K; iso BK), Thailand. Pattani.

Shrubs; branchlets thinly appressed-pubescent. Leaves: blades lanceolate to oblong-lanceolate, $8-13$ by $3-4 \mathrm{~cm}$, subcoriaceous, yellowish brown when dry, glabrous above, sparsely strigose on nerves beneath, apex acute to shortly caudate or acuminate, base acute; midrib, nerves and nervules prominent on both surfaces, nerves 3-6 pairs, nervules subreticulate; petioles 4-5 mm long, sparsely strigose. Stipules small, triangular, 3-4 mm long, sparsely strigose. Cymes sessile or subsessile; bracts absent. Flowers sessile, small, crowded; calyx with an obconical tube and a hemispherical limb, minutely strigose, somewhat constricted at the throat, tube 1.5-2 mm long, limb shortly 4-toothed or almost truncate, c. $1 \mathrm{~mm}$ long; corolla hirsute or glabrous outside, tube about $3 \mathrm{~mm}$ long, lobes c. 2 $\mathrm{mm}$ long. Drupes ovoid or ellipsoid, with a constricted base, glabrous, crowned by a cupular calyx-limb which is somewhat constricted at base; pyrenes $2-4$, very furrowed on the abaxial face.

Distribution - Burma, Thailand (Peninsular), Singapore, Malaysia (Sarawak, Sabah), Brunei, Indonesia (Sumatra, Java, Kalimantan).

Notes - Var. latifolius differs from the typical variety by having broader leaves. However, the demarcation becomes vague when more specimens are checked and var. latifolius cannot be clearly separated from var. constrictus.

This species has a calyx constricted at base of cupular limb and drupes crowned by calyx limb constricted at base with 2-4 developed pyrenes. The same type of drupes is found in L. reticulatus ( $=L$. maingayi). Lasianthus constrictus is very closely related to $L$. reticulatus. It differs from $L$. reticulatus by having relatively small leaves with $3-5$ pairs of nerves and subglabrous or sparsely strigose branches and leaf nerves beneath, shorter petioles, cymes usually sessile, calyx limb truncate or minutely toothed, while $L$. reticulatus has appressed-pubescent hairs on branches and nerves beneath, leaves relatively large with 6-7 pairs of nerves which are strongly prominent beneath, flowers sessile clustered in very short congested peduncles, calyx limb with 4 minutely triangular lobes. 


\section{Lasianthus cordatus Merr.}

Lasianthus cordatus Merr. (1929a) 293. — Type: Elmer 21865 (iso CAS, L, SING), Borneo (Sabah), Tawao.

Shrubs, glabrous; branchlets terete, c. $2 \mathrm{~mm}$ diam, more or less compressed or sulcate, red-brownish. Leaves: blades oblongelliptic, $15-20$ by $5-7.5 \mathrm{~cm}$, chartaceous, nitid both surfaces, apex cuspidate, base rounded to subcordate, slightly asymmetric, midrib and nerves prominent on both surfaces, nerves 5-7 pairs, ascending at an angle of c. $70^{\circ}$, curved to the margin, uppermost two pairs joining near the leaf margin and forming an obscure intramarginal vein, internerved vein conspicuous, nervules distinct on both surfaces, reticulate; petioles very short to subsessile. Stipules triangular-lanceolate, c. $3 \mathrm{~mm}$ long, sparsely hirsute. Cymes sessile; bracts with a midrib, numerous, oblonglanceolate to oblanceolate, glabrous, coriaceous, 5-10 mm long, obtuse at the apex. Flowers sessile; calyx tube glabrous, c. $2 \mathrm{~mm}$ long, lobes 5, oblong to oblong-ovate, obtuse at apex, c. $1 \mathrm{~mm}$ long, glabrous or sparsely ciliate at margin; corolla not seen. Drupes ovoid, glabrous, c. $8 \mathrm{~mm}$ long; pyrenes 4 .

Distribution - Malaysia (Sabah).

Notes - From Merrill's description, this species has stipules which are oblong, obtuse, 5-7 mm long. However, from our examining the type specimen, it has stipules, which are triangular-lanceolate, $3 \mathrm{~mm}$ long; but has numerous bracts, which are oblong to lanceolate, 5-10 $\mathrm{mm}$ long, which match the description of "stipules" by Merrill.

This species is closely related to L. membranaceus. It differs from the latter by having leaves usually with rounded or cordate base, numerous bracts, which are oblong to lanceolate, 5-10 $\mathrm{mm}$ long and drupes with 4 pyrenes. Lasianthus membranaceus has leaves with acute base, small, linear bracts, and drupes usually with 2 pyrenes. However, as mentioned by Merrill, the apical portion of branchlets of $L$. cordatus bears leaves without a cordate base, which make it close to L. membranaceus.

\section{Lasianthus coriaceifolius H.Zhu, sp. nov. - Fig. 10}

Proximus L. myrtifolio Ridl. subsp. vicario H.Zhu, sed foliis majoribus 9-11 $\mathrm{cm}$ longis $3-4.5 \mathrm{~cm}$ latis, nervulis reticulatis, calycibus majoribus, tubis calycis longioribus, lobis calycis ovato-oblongis et drupis acute 8-porcatis differt. - Typus: Lee S.52556 (holo L; iso K), Borneo, Sarawak, Ulu Trusan Lawas, 900 m alt., in hill mixed dipterocarp forest, 12 May 1986.

Treelet, 4-5 m high; branchlets terete, 3-4 mm diam, fistulose, glabrous, darkish. Leaves: blades lanceolate-oblong or oblong, $9-15$ by $3-6 \mathrm{~cm}$, thickly coriaceous, glabrous on both surfaces; apex abruptly acute, base acute to subrounded, midrib slightly depressed above, conspicuously prominent beneath, darkish, nerves prominent on both surfaces, $6-8$ pairs, ascending at an angle of c. $80^{\circ}$, curved to margin; nervules prominent on both surfaces, conspicuously reticulate, margin conspicuously recurved; petioles $0.5-1 \mathrm{~cm}$ long, glabrous, darkish. Stipules triangular, c. 3 by $3 \mathrm{~mm}$, glabrous. Inflorescences sessile; bracts inconspicuous. Flowers fascicular, sessile; calyx longcampanulate, sparsely puberulous or glabrous, darkish, tubes c. $3 \mathrm{~mm}$ long, lobes 4, ovate-oblong, c. $2 \mathrm{~mm}$ long; corolla 8-9 $\mathrm{mm}$ long, glabrous external surface. Drupes ellipsoid, 5-6 mm diam, with 8 acute, conspicuous ridges, glabrous, crowned by persistent calyx lobes; pyrenes 4 , rhombic-circular in the transverse section.

Distribution - Malaysia (Sarawak) and Brunei.

Habitat \& Ecology — In montane forest. Flowering and fruiting between May and September.

Note - This species is characterized by its glabrous plants, thickly coriaceous leaves with reticulate nervules and conspicuously recurved margin, and 8-ridged drupes. It is closely related to $L$. myrtifolius subsp. vicarius, but differs from the latter by having relatively big leaves $(9-11$ by $3-4.5 \mathrm{~cm}$ ) with reticulate nervules, relatively big calyx (5 $\mathrm{mm}$ long) with longer calyx tubes and ovate-oblong calyx lobes, drupes with 8 acute ridges. Lasianthus myrtifolius subsp. vicarius has leaves $4.5-7.5$ by 2-3 cm, nervules parallel, calyx campanulate, $2-3 \mathrm{~mm}$ long with triangular calyx lobes, drupes without conspicuous ridges.

\section{Lasianthus coronatus King \& Gamble}

Lasianthus coronatus King \& Gamble (1904) 120; Ridl. (1923a) 157. — Type: Scortechini 329 (iso K), Peninsular Malaysia, Perak.

Lasianthus wallichii Wight? var. penangensis Hook.f. (1880) 181. - Type: Wall. Cat. 8441, p.p (holo K), Peninsular Malaysia.

Lasianthus politus Ridl. var. insularis Craib (1934) 216, syn. nov. — Type: Put 1195 (holo K), Thailand, Surat.

Shrubs; branchlets terete, c. $2 \mathrm{~mm}$ diam, densely tomentose. Leaves: blades oblong-lanceolate, $5-10$ by $1.5-3 \mathrm{~cm}$, coriaceous, glabrous above except sometime hairy midrib, tomentose beneath, apex acuminate to caudate-acuminate, base cuneate to subrounded, slightly asymmetric, midrib and nerves flat or slightly depressed above, prominent beneath, nerves 6-9 pairs, ascending at an angle of c. $60^{\circ}$, curved to the margin, nervules obscure above, distinct beneath, subparallel; petioles c. $2 \mathrm{~mm}$ long, densely tomentose. Stipules inconspicuous. Cymes sessile; bracts linear, 5-8 mm long, densely tomentose. Flowers sessile; calyx and corolla not seen. Drupes subglobose, tomentose, crowned by 5 linear calyx lobes; pyrenes 5 .

Distribution - Thailand (Peninsular), Peninsular Malaysia.

Note - This species has tomentose hairs on branchlets, leaf nerves beneath, stipules, bracts; leaves oblong-lanceolate with cuneate to subrounded base, bracts linear; drupes with 5 pyrenes. It is quite close to $L$. attenuatus, but differs from the latter by having leaves with cuneate or subrounded base and slender linear bracts.

\section{Lasianthus crassinervis Ridl.}

Lasianthus crassinervis Ridl. (1910) 59. - Type: Ridley 14487 (holo SING; iso K), Peninsular Malaysia, Ulu Temengoh. Lasianthus retosus auct. non Wight: K.M.Wong (1989) 371

Shrubs, c. $1 \mathrm{~m}$ high; branchlets terete, $2-3 \mathrm{~mm}$ diam, densely brown-tomentose. Leaves: blades oblong, $9-19$ by $3-4 \mathrm{~cm}$, subcoriaceous, glabrous above, tomentose beneath, apex cuspidate, base rounded to subcordate, oblique, margin reflexed, nerves 10-13 pairs, depressed above, prominent beneath, ascending at an angle of c. $50^{\circ}$, curved to the margin, nervules slightly obscure above, distinct beneath, subparallel; petioles c. $3 \mathrm{~mm}$ long, densely tomentose. Stipules triangular, c. 3 by $3 \mathrm{~mm}$, densely tomentose. Cymes sessile; bracts numerous, outer pairs leaf-like, ovate, up to $1 \mathrm{~cm}$ long, inner ones smaller, lanceolate to linear, all of them densely tomentose. Flowers sessile; calyx and corolla not seen. Drupes globose, glabrous, 3-4 mm diam, verrucose, crowned by small triangular calyx lobes which are c. $0.5 \mathrm{~mm}$ long; pyrenes $4-5$, verrucose on the abaxial face.

Distribution - Peninsular Malaysia.

Notes - This species has nerves which are conspicuously depressed above and elevated beneath, subparallel nervules which are faint above and conspicuous beneath, ovate to lanceolate bracts, as well as glabrous and verrucose drupes.

Ridley (1923a) reduced it to $L$. retosus that he sank to a variety as $L$. pilosus var. retosus. However, it conspicuously differs from L. pilosus ( $=L$. retosus) by having leaves with strongly depressed nerves above, bracts which are obovate to lanceolate, $0.8-$ $1.2 \mathrm{~cm}$ long and glabrous drupes. Lasianthus pilosus has leaves with nerves slightly depressed above, linear bracts, and pilose drupes with smooth surface. 

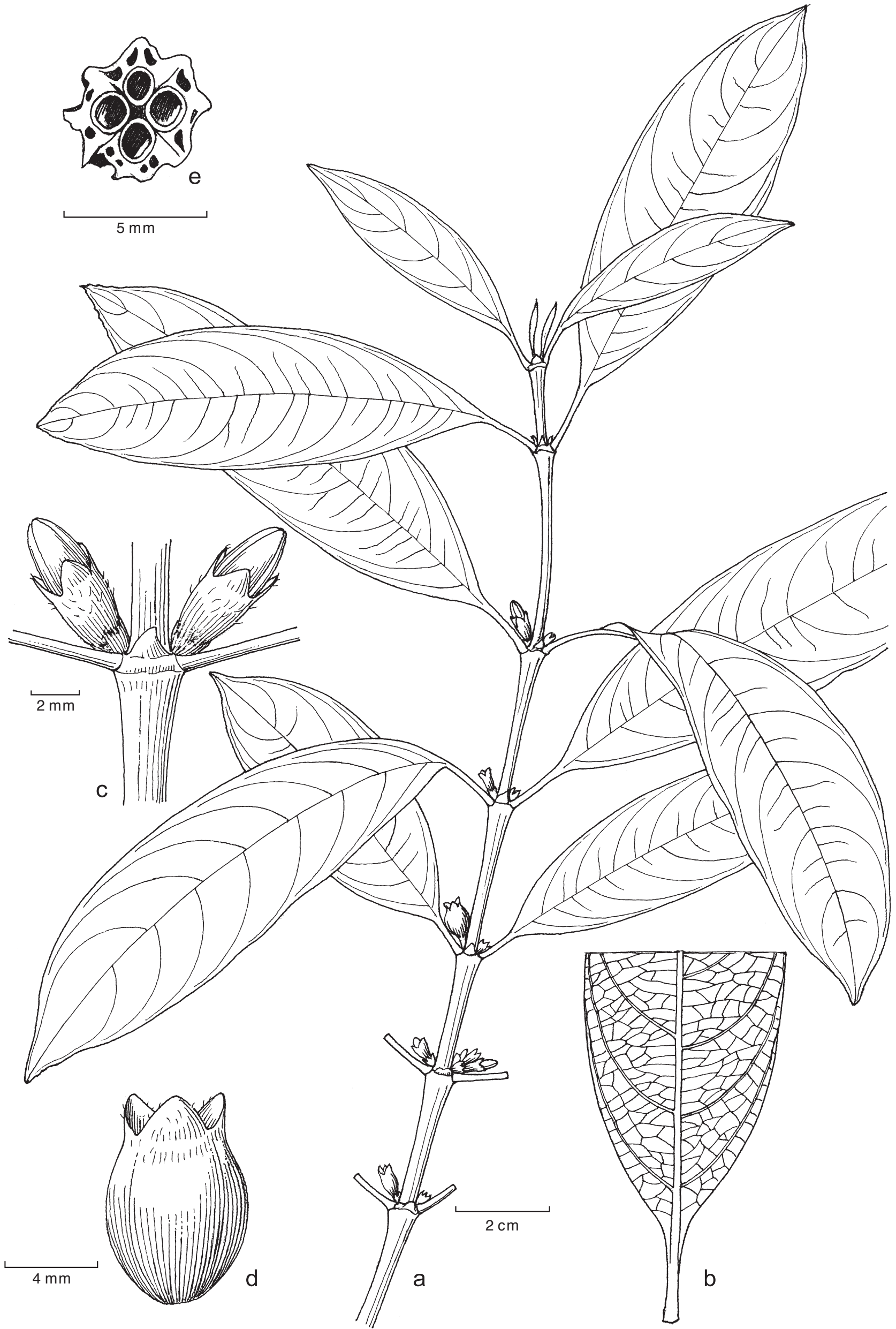

Fig. 10 Lasianthus coriaceifolius H.Zhu. a. Habit with inflorescences; b. lower surface of leaf showing reticulate nervules; c. detail of node showing stipule and axillary inflorescences; d. fruit; e. cross section of fruit (all: B. Lee S.52556, holo L). 


\section{Lasianthus crinitus Hook.f.}

Lasianthus crinitus Hook.f. (1880) 182. - Type: Wall. Cat. 8441, p.p. (holo $\mathrm{K})$, Peninsular Malaysia, Penang, or Singapore.

Shrubs; branchlets terete, c. $3 \mathrm{~mm}$ diam, densely brown-tomentose. Leaves: blades oblong, $10-15$ by $2.5-4 \mathrm{~cm}$, coriaceous, glabrous above, densely brown-tomentose beneath, apex acute to acuminate, base rounded, margin reflexed, midrib and nerves flat to slightly depressed above, prominent beneath, nerves 8-9 pairs, ascending at an angle of c. $50^{\circ}$, curved to the margin, nervules distinct above, distinct and prominent beneath, parallel; petioles 3-4 mm long, densely brown-tomentose. Stipules inconspicuous. Cymes sessile; bracts numerous, filiform, up to $1 \mathrm{~cm}$ long, densely tomentose, forming a dense head. Flowers clustered, sessile; calyx and corolla not seen. Drupes globose, c. $3 \mathrm{~mm}$ diam, densely brown-tomentose, 5-ridged, crowned by 5 linear calyx lobes which are c. $2 \mathrm{~mm}$ long and tomentose; pyrenes 5 .

Distribution - Peninsular Malaysia.

Note - This species has branchlets and leaf blades beneath rusty-tomentose, cymes sessile, bracts filiform, dense and numerous. The type is a fragment mounted with two other taxa, i.e. $L$. attenuatus and $L$. attenuatus var. minor on the same sheet. Only one specimen from Peninsular Malaysia (FRI 15716 from Fraser's hill of Pahang) in $L$ that we examined matches the type and description. This species is closely related to $L$. lineolatus Craib by its indumentum and bracts.

\section{Lasianthus curtisii King \& Gamble - Map 4}

Lasianthus curtisii King \& Gamble (1904) 128; Ridl. (1923a) 161; Craib (1934) 209; T.Yamaz. (1964) 352, p.p.; T.S.Liu \& J.M.Chao (1964) 126, f. 5; H.Zhu (1994) 64; (1998) 151; H.S.Lo (1999) 92; H.Zhu (2001b) 126; (2002) 86. - Lectotype: Curtis 284 (lecto SING, designated by Zhu 2002; isolecto $\mathrm{K})$, Peninsular Malaysia, Penang.

Lasianthus formosensis Matsum. var. hirsuta Matsum. (1901) 17. - Type: Owatari s.n. (holo TI, n.v.), Taiwan.

Lasianthus kwangtungensis Merr. (1929b) 323. - Type: Tsiang 55 (holo $\mathrm{SCBI}$; iso $\mathrm{K}$ ), China, Hongkong.

Lasianthus condorensis Pierre ex Pit. (1924) 385. - Syntypes: Balansa 2658 (P), Vietnam Tonkin, Bavi; Eberhardt 1981 (P), Annam, Quang-tri; Harmand $916(\mathrm{P})$, Cochinchina [Vietnam], Condor.

Lasianthus pseudo-Iucidus King \& Gamble (1904) 128; Ridl. (1923a) 168. Type: Wray 4109 (holo SING), Peninsular Malaysia, Perak, $5000 \mathrm{ft}$.

Shrubs, 1-2 m tall; branches and branchlets terete, c. 1.5-2 $\mathrm{mm}$ diam, densely villous. Leaves: blades ovate-lanceolate or elliptic-lanceolate, $5-9$ by $2-3 \mathrm{~cm}$, subcoriaceous, glabrous above, densely and softy villous beneath, apex cuspidateacuminate, base cuneate or obtuse, midrib and nerves flat above, prominent beneath, nerves 4-6 pairs, ascending at an angle of $50-60^{\circ}$, curved to the margin, nervules obscure above, distinct beneath, subparallel; petioles $4-5 \mathrm{~mm}$ long, villose. Stipules minute, inconspicuous. Cymes sessile; bracts absent. Flowers sessile; calyx divided nearly to the base into 5 lanceolate up to $5 \mathrm{~mm}$ long, acuminate lobes, hirsute outside; corolla 7-8 mm long, 5-lobed, outside hispid, inside villous, the throat hairy. Drupes ovoid-globose, hirsute, 4-5 mm diam, crowned by the long persistent calyx lobes; pyrenes 5 .

Distribution - China, Japan (Amami, Kyushu, Ryukyu), Vietnam, Thailand, Peninsular Malaysia, Indonesia (Sumatra).

Note - Wong (1989) reduced L. pseudo-lucidus to L. curtisii. Lasianthus pseudo-lucidus is very closely related to $L$. curtisii in having calyx almost the same as the latter. However, it has narrower leaves, which is a little different from the typical $L$. curtisii.

\section{Lasianthus cyanocarpoides Valeton}

Lasianthus cyanocarpoides Valeton (1927) 108; Merr. \& L.M.Perry (1946) 219. - Type: Schlechter 17805 (holo S; iso K, L), Papua New Guinea, Kaiser-Wilhemsland, 1000 m, 29 May 1908.

Shrubs to treelets, up to $2 \mathrm{~m}$ high; branchlets terete, c. $3 \mathrm{~mm}$ diam, densely hirsute, dark-brown when dry. Leaves: blades oblong-elliptic, rarely obovate, $10-15$ by $4-6 \mathrm{~cm}$, coriaceous, glabrous above except hirsute hairs on midrib, hirsute beneath, apex cuspidate to cuspidate-caudate, base cuneate, slightly asymmetric, nerves 9-13 pairs, flat to slightly depressed above, prominent beneath, ascending at an angle of c. $60^{\circ}$, curved to the margin, nervules obscure above, prominent beneath, subreticulate; petioles 5-8 $\mathrm{mm}$ long, densely dark-brown-hirsute. Stipules linear-lanceolate to triangular-lanceolate, up to $8 \mathrm{~mm}$ long, hirsute, cadulous. Cymes sessile; bracts numerous, hirsute, outer ones with a midrib, leaf-like, lanceolate, up to $1.5 \mathrm{~cm}$ long, hirsute, inner ones smaller, lanceolate to linear. Flowers sessile; calyx obconical, c. $2 \mathrm{~mm}$ long, densely longhirsute, lobes 5 , subulate, c. $1 \mathrm{~mm}$ long; corolla tube c. $5 \mathrm{~mm}$ long, hirsute, lobes 5, triangular, c. $3 \mathrm{~mm}$ long, hirsute. Drupes subglobose, c. $3 \mathrm{~mm}$ diam, hirsute; pyrenes 5 , smooth on the abaxial face.

Distribution — Indonesia (Irian Jaya), Papua New Guinea.

\section{Lasianthus cyanocarpus Jack}

Lasianthus cyanocarpus Jack (1823) 125; Miq. (1857) 316; (1869) 245 (p.p. excl. syn. L. densifolius Miq.); Merr. (1952) 229; Bakh.f. (1965) 338. — Type: Jack s.n. (lost), Sumatra, Tappanooly (west coast of Sumatra), Borssum 1864 (neo L, designated here), west coast, Lubuk Sikaping.

Lasianthus inaequalis Blume (1826-1827) 996; Miq. (1857) 316; King \& Gamble (1904) 114; Elmer (1906b) 10; Merr. (1921) 578; (1923) 566; Ridl. (1923a) 155; Valeton (1927) 106; Merr. (1937) 298; K.M.Wong (1989) 370; H.Zhu (2001b) 131, syn. nov. - Type: Blume s.n. (lecto L, here designated, barcode L0000688; isolecto K), Java, Seribu.

Lasianthus cyanocarpus Jack var. subsessilis King \& Gamble (1904) 113. — Syntypes: Ridley 9730 (n.v.), Perk; King's collector 472 (K); Scortechini 1207 (K).

Lasianthus subinaequalis King \& Gamble (1904) 120; Ridl. (1923a) 155; Craib (1934) 218. - Syntypes: King's collector 157 (n.v.), 3358 (n.v.), Ridley 9715 (SING), Wray 2588 (SING), 3451 (SING), Peninsular Malaysia, Perak.

Lasianthus bractescens Ridl. (1918) 85; (1923a) 154; K.M.Wong (1989) 370, syn. nov. - Type: Ridley 8213 (syn K), Peninsular Malaysia, Selangor, Batu Caves.

Lasianthus bractescens Ridl. var. rosulatus Ridl. (1918) 85; (1923a) 154 syn. nov. - Type: Ridley s.n. (n.v.), Peninsular Malaysia, Perak.

Lasianthus inaequalis Blume var. angustibractea Valeton (1927) 107, syn nov. - Type: Schlechter 19334 (syn K), New Guinea.

Shrubs; branches terete, 1.5-2 mm diam, densely tomentose. Leaves: blades elliptic-oblong to oblanceolate-oblong, $8-13.5$ by $2.5-4.5 \mathrm{~cm}$, membranaceous, glabrous except tomentose midrib and puberulous nerves above, or all tomentose, softly tomentose beneath, apex shortly acuminate or caudate, base rounded, oblique or oblique cordate, midrib conspicuous above, prominent beneath, nerves 7-10 pairs, flat above, prominent beneath, ascending at an angle of c. $50^{\circ}$, curved to the margin, nervules obscure above, distinct beneath, subreticulate; petioles short, c. $2 \mathrm{~mm}$ long, densely tomentose. Stipules linear, inconspicuous, densely tomentose, deciduous. Cymes sessile; bracts numerous, densely tomentose, outer ones leaf-like, broadly ovate, abruptly acuminate at apex, up to $1.8 \mathrm{~cm}$ long, long-tomentose, inner ones becoming smaller. Flowers sessile; calyx campanulate with 4-5 deep unequal lanceolate or linear-lanceolate tomentose 3-4 $\mathrm{mm}$ long lobes; corolla short, 4-5-lobed, glabrous inside, long yellow pilose outside. Drupes ovoid, sparsely pilose, crowned by the persistent calyx lobes; pyrenes 4, rugose.

Distribution - Thailand, Malaysia (Peninsular, Borneo), Indonesia (Sumatra, Java, Kalimantan, Lesser Sunda Islands, Irian Jaya), Philippines, Papua New Guinea. 


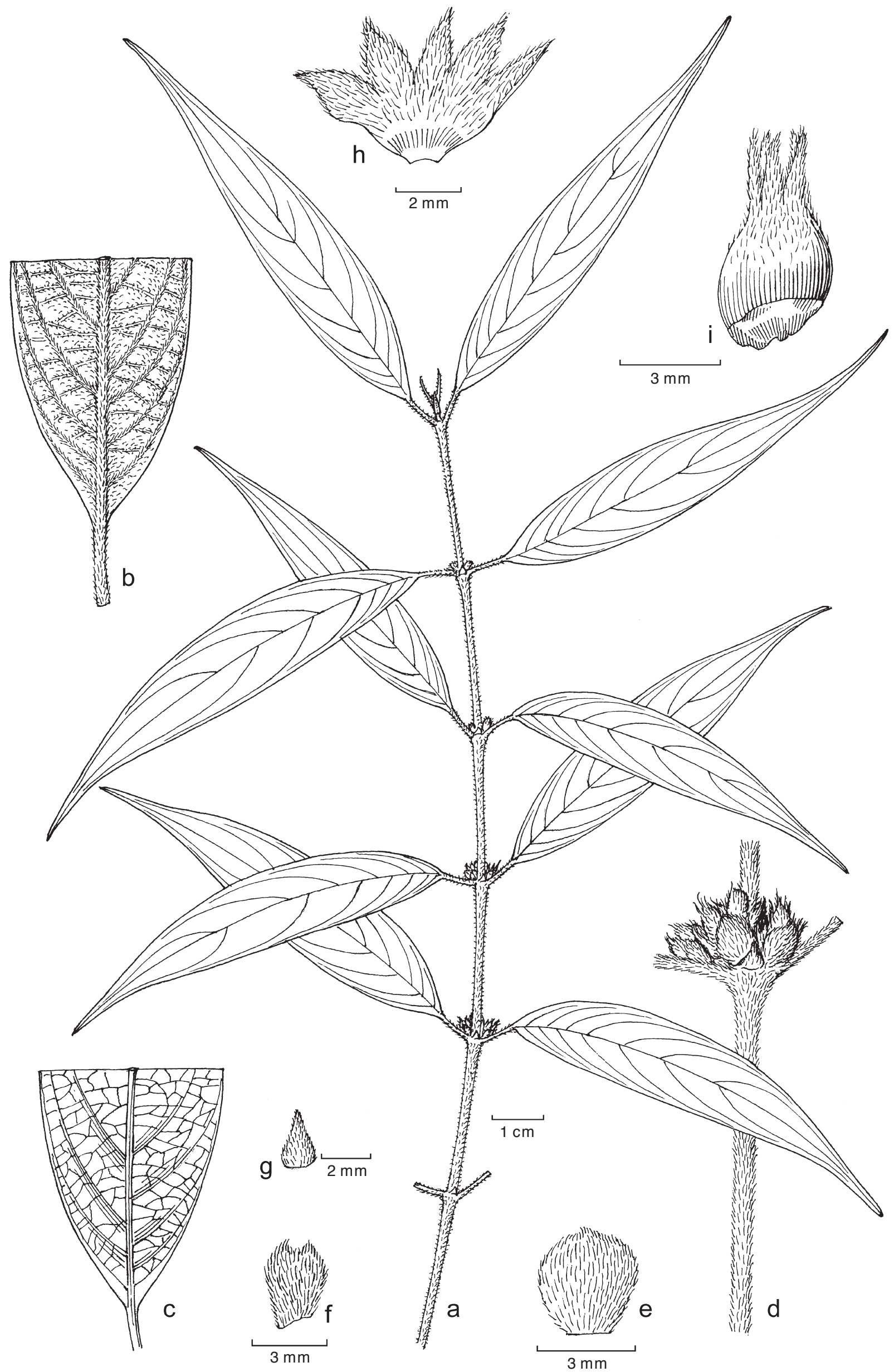

Fig. 11 Lasianthus depressineurus H.Zhu. a. Habit with inflorescences; b. detail of lower surface of leaf; c. detail of upper surface of leaf showing reticulate nervules; d. detail of node showing stipule and axillary inflorescence; e. bract; f. bracteole; g. stipule; h. calyx split opened; i. immature fruit (all: Dyg Awa \& B. Lee S.50579, holo L). 
Notes - As mentioned earlier in this paper, Jack's holos were destroyed by fire in 1824 . The type of $L$. cyanocarpus was certainly lost. The name $L$. cyanocarpus has been misused for the species $L$. hirsutus for a long time and in many taxonomic references as pointed out by Merrill (1952).

A specimen Blume s.n. (L0000688) from Seribu of Java indicated as $L$. inaequalis with Blume's handwriting is recognised to be a syntype and here designated as lectotype because more than one locality was mentioned in Blume's original description.

Miquel (1869) reduced $L$. inaequalis to a synonym of $L$. cyanocarpus. Merrill (1952) confirmed that $L$. inaequalis from Java is conspecific to $L$. cyanocarpus. Bakhuizen van den Brink Jr (1965) followed Miquel and Merrill in the treatments of Java Lasianthus. From Jack's description L. cyanocarpus has large cordate bracts, which is a key diagnostic character. After checking all Malesian specimens, we are sure that $L$. inaequalis is conspecific to $L$. cyanocarpus. Miquel's and Merrill's treatments are correct.

Lasianthus cyanocarpus is very closely related to $L$. attenuatus, but differs from the latter by having cordate to broadly lanceolate, somewhere leaf-like bracts. Lasianthus cyanocarpus differs from $L$. hirsutus by having relatively small leaves with cordate, slightly oblique bases, usually less and relatively small bracts. Lasianthus hirsutus has relatively large leaves with cuneate, little unequal base; relatively long petioles; conspicuous triangular stipules; more bracts with outer ones ovate-oblong, and leaf-like, inner ones gradually narrower and smaller; as well as usually long rough hairs cover.

From Ridley's description, $L$. bractescens var. rosulatus has oblong, broad and sessile leaves with unequal base; bracts ovate acute, forming a rosette, which strongly suggest it is the same species as $L$. cyanocarpus although its type is not seen.

\section{Lasianthus depressineurus H.Zhu, sp. nov. - Fig. 11}

Proximus $L$. inodorus Blume, sed foliis minoribus ovato-lanceolatis, costis et nervis supra conspicue depressis, lobis calycis ovatis longioribus tubo differt. - Typus: Dyg Awa \& Lee S.50579 (holo L; iso K, MO), Borneo, Sarawak, Bt. Lawi, Bario, $1290 \mathrm{~m}$ alt., in hill mixed dipterocarp forest, on top of the ridge, 3 Aug. 1985.

Treelet, $2 \mathrm{~m}$ high; branchlets slender, terete, c. $1 \mathrm{~mm}$ diam, densely tomentose. Leaves: blades ovate-lanceolate, 8-11 by $1.5 \mathrm{~cm}$, coriaceous, glabrous except pubescent midrib and nerves beneath, apex caudate, base acute or subrounded; midrib and nerves deeply depressed above, strongly prominent beneath, nerves $6-7$ pairs, ascending at an angle of $45-60^{\circ}$, curved to margin, nervules obscure above, prominent beneath, reticulate, glabrous, margin conspicuously recurved; petioles 5-8 mm long, densely tomentose. Stipules triangular, c. $2 \mathrm{~mm}$ long, densely tomentose. Inflorescences sessile; bracts ovateorbicular, c. $3 \mathrm{~mm}$ long, pubescent surfaces; bracteoles oblong, c. $2.5 \mathrm{~mm}$ long, pubescent. Flowers fascicular, sessile; calyx campanulate, pubescent, lobes 5 , ovate, c. $2.5 \mathrm{~mm}$ long, 1.5 $\mathrm{mm}$ broad, pubescent both surfaces, densely hirsute on margin, tubes c. $2 \mathrm{~mm}$ long; corolla not seen. Drupes globose, c. $3 \mathrm{~mm}$ diam, pubescent, crowned by persistent ovate, c. $4 \mathrm{~mm}$ long calyx lobes; pyrenes 4 , smooth on the abaxial face.

Distribution - Malaysian (Sarawak).

Habitat \& Ecology - In montane forest between 1290$1400 \mathrm{~m}$ altitude. Flowering and fruiting in August.

Additional specimen examined. Borneo, Sarawak, Limbang, D. Awa \& B. Lee $\mathrm{S.47839( \textrm {L } )}$

Note - This species is characterized by its deeply depressed midrib and nerves above surface and ovate-orbicular bracts. It seems to be related to $L$. inodorus, but conspicuously differs from the latter by having small ovate-lanceolate leaves with deeply depressed midrib and nerves above, ovate calyx lobes longer than the tube.

\section{Lasianthus dinghouanus H.Zhu, sp. nov. - Fig. 12}

Proximus L. laxifloroideo H.Zhu, sed foliis lineari-lanceolatis $1-2 \mathrm{~cm}$ latis apice longicaudatis, floribus minoribus, lobis calycis triangularis $0.8 \mathrm{~mm}$ longis differt. A L. foetidissimo A.Chev. ex Pit. foliis apice longicaudatis, nervis 3-4-binatis, floribus 4-meris, drupis glabris et pyrenis 4 differt. - Typus: Dyg Awa et al. S.46999 (holo L; iso K, L), Borneo, G. Kanji, Lindu, 530 m alt., in non-dipterocarp forest on sandy soil, 18 Apr. 1984.

Treelet, $4 \mathrm{~m}$ high, $2 \mathrm{~cm}$ diam; branchlets slender, terete, c. $2 \mathrm{~mm}$ diam, subglabrous to appressed-pubescent, brown. Leaves: blades linear-lanceolate, $10-14$ by $1-2 \mathrm{~cm}$, chartaceous to subcoriaceous, glabrous except more or less appressed-pubescent midrib and nerves beneath, apex long caudate, margin recurved, base acute to acuminate, midrib flat above, prominent beneath, nerves flat above, prominent beneath, 3-4 pairs, nervules slightly obscure above, conspicuous beneath, parallel, glabrous; petioles 8-10 mm long, slender, more or less appressed-pubescent. Stipules subulate-triangular to triangular, 1-1.5 mm long, pubescent. Inflorescences peduncled; peduncles 5-20 mm long, slender, trifurcate at apex, more or less pubescent; bracts very small, subulate, c. $1 \mathrm{~mm}$ long, pubescent. Flowers shortly pediceled; calyx campanulate, pubescent, tube c. $1 \mathrm{~mm}$ long, lobes 4 , triangular, c. $0.8 \mathrm{~mm}$ long; corolla c. $5 \mathrm{~mm}$ long, tube glabrous outside, lobes 4 , ovate, c. $1 \mathrm{~mm}$ long, pubescent external surface. Drupes with 1-2 mm long pedicels, globose, c. $4 \mathrm{~mm}$ diam, glabrous but very verrucose, 4-ridged; pyrenes 4, verrucose on the abaxial face.

Distribution - Endemic to Borneo.

Habitat \& Ecology - Lower montane forest between 500 $1300 \mathrm{~m}$ altitude. Flowering and fruiting between April and October.

Additional specimens examined. Sarawak, Lundu, Ftr. Ilias Paie S.13619 (K, L); same locality, J.D. Mamit S.35169 (K, L); same locality, P.S.Ashton S.18876 (K, L); Sarawak, Gunong Silantek, Ilias Paie S.42455 (K, L); Sarawak, G.Buri, P.Chai et al. S.36803 (L).

Note - This species is closely related to $L$. laxifloroideus. It differs from the latter by having glabrous or sparsely appressed-pubescent on branches and leaf midrib beneath, leaves linear-lanceolate, less than $2 \mathrm{~cm}$ broad; leaf apex long caudate; flowers relatively small, calyx lobes triangular, c. 0.8 $\mathrm{mm}$ long. It is also similar to $L$. foetidissimus, but differs from the latter by having leaves with a long caudate apex, nerves 3-4 pairs, flowers 4-merous, drupes glabrous with 4 pyrenes. Lasianthus foetidissimus has leaves with an acuminate and mucronate apex; nerves 6 pairs; flowers 5-merous; drupes pubescent with 5 pyrenes.

\section{Lasianthus ellipticus Wight}

Lasianthus ellipticus Wight (1846) 507; Hook.f. (1880) 182; King \& Gamble (1904) 118; Ridl. (1923a) 159; K.M.Wong (1989) 372; H.Zhu (2001b) 126. - Type: Kew Distrib. 2934 (Griffith s.n.) (holo K), Peninsular Malaysia. Lasianthus venulosus Ridl. (1912) 23, non Wight (1846). — Syntypes: Chan Chu Kang 6146 (n.v.), Ridley 12542 (iso K), Bukit Panjang, Singapore. Lasianthus sordidus Ridl. (1911) 60. - Type: Ridley 14488 (iso K), Peninsular Malaysia, Ulu Temengoh.

Lasianthus scalaris Craib (1933) 26; (1934) 216. - Type: Kerr 18809 (holo $\mathrm{K}$; iso $\mathrm{BK})$, Thailand, Puket.

Lasianthus velutinus Ridl. (1920) 144; (1923a) 159; K.M.Wong (1989) 372, syn. nov. - Type: Ridley s.n. (holo SING; iso K), Peninsular Malaysia, Kelantan.

Shrubs, 1-2 m high, branchlets densely hirsute to tomentose. Leaves: blades elliptic or oblong-elliptic, $10-15$ by $5-7 \mathrm{~cm}$, rigid chartaceous to subcoriaceous, usually glabrous above, appressed-hirsute on midrib, nerves and nervules beneath, apex acute to shortly caudate or cuspidate-acuminate, base broadly cuneate to subrounded, midrib slightly depressed above, 


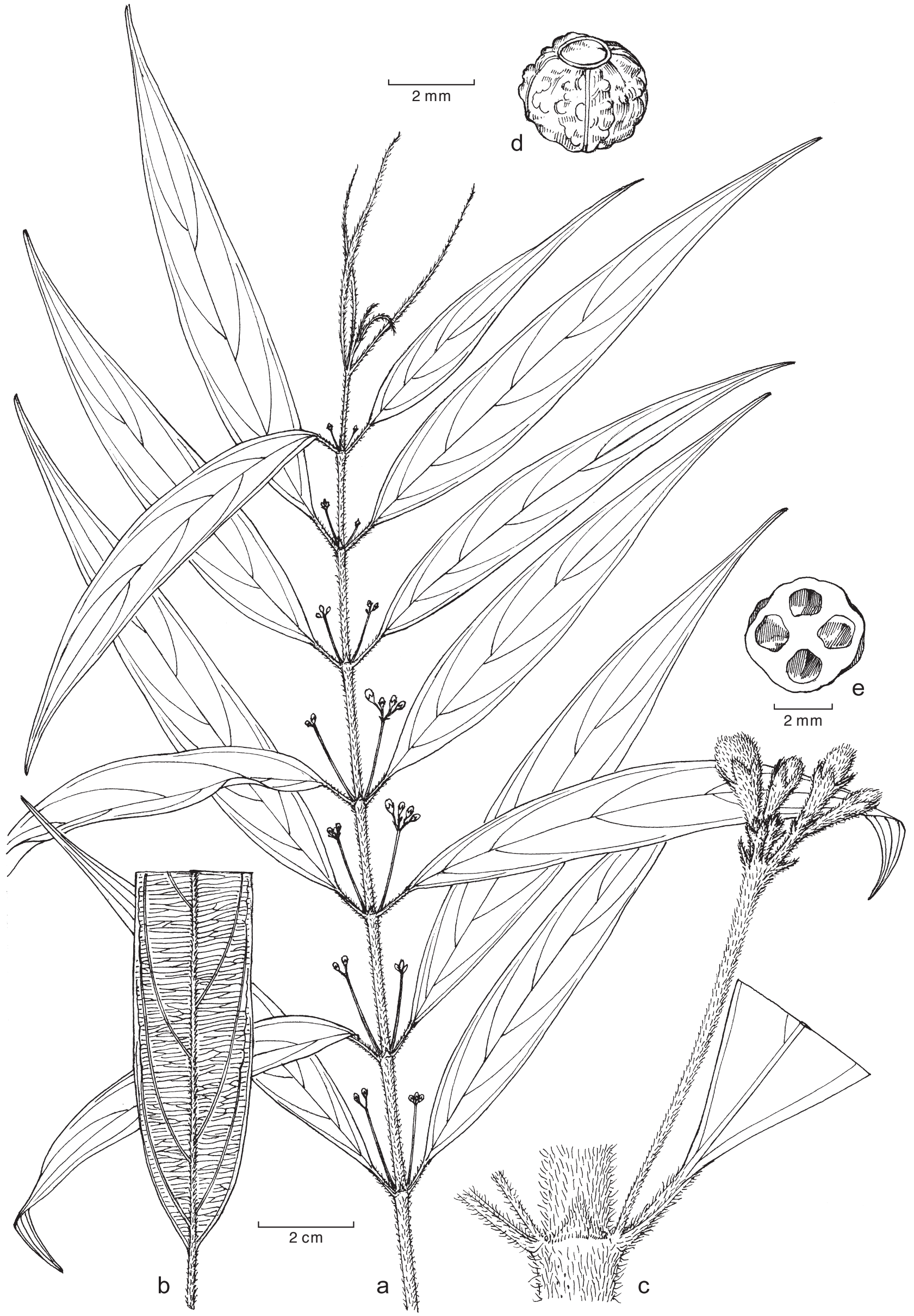

Fig. 12 Lasianthus dinghouanus H.Zhu. a. Habit with inflorescences; b. lower surface of leaf showing parallel nervules; c. detail of node showing stipule and axillary inflorescence; d. fruit; e. cross section of fruit (all: Dyg Awa et al. S.46999, holo and iso L). 


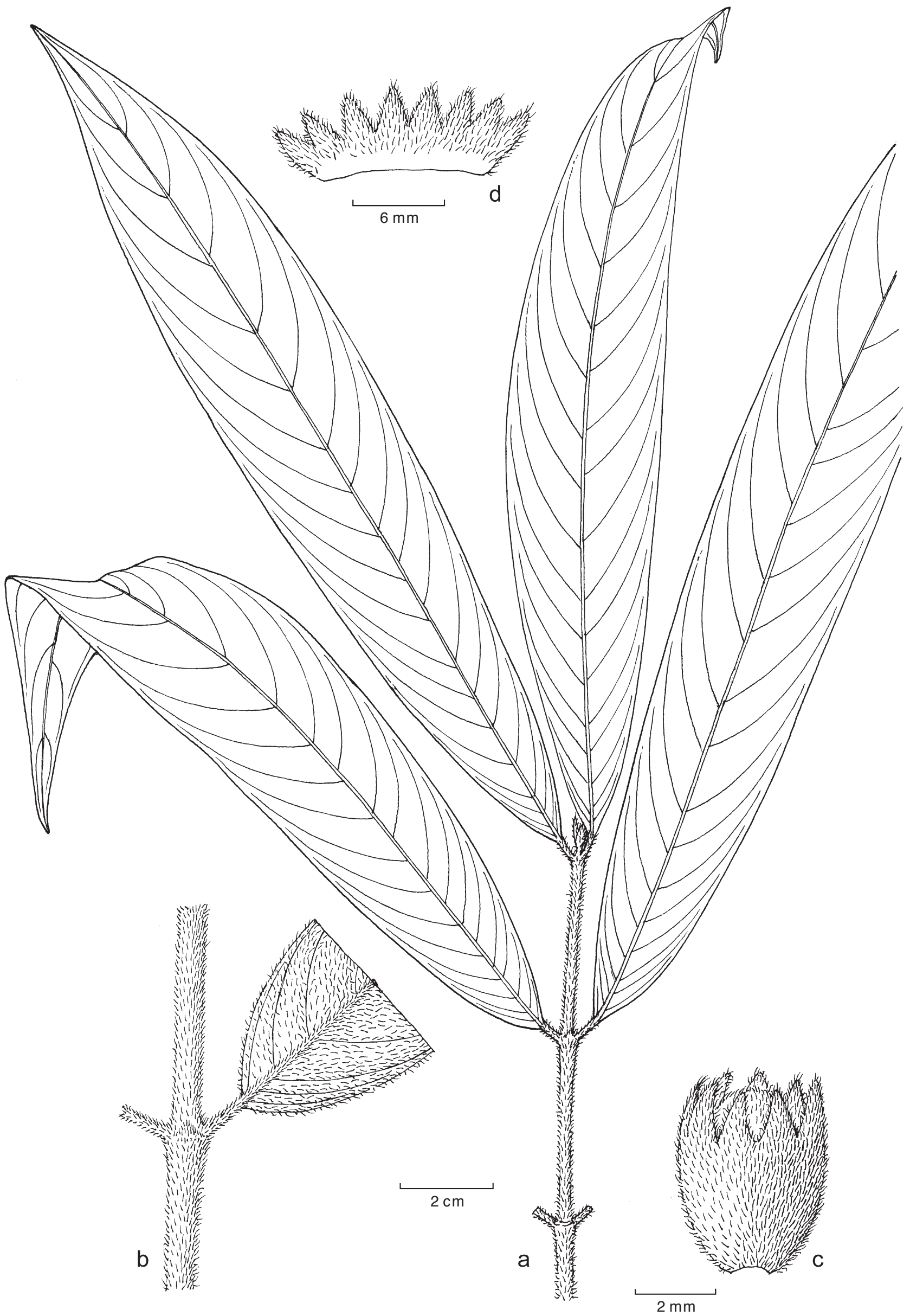

Fig. 13 Lasianthus eriocalyx H.Zhu. a. Habit with inflorescences; b. detail of branch; c. immature flower; d. calyx split opened (all: F.S.P. Ng s.n. KEP-FRI 22027, holo L). 
prominent beneath, nerves and nervules conspicuous or slightly prominent above, prominent beneath, nerves 7-9 pairs, ascending at an angle of c. $50^{\circ}$, curved to the margin, nervules parallel, margin recurved; petioles $0.8-1.7 \mathrm{~cm}$ long, densely hirsute. Stipules broadly triangular, up to $7 \mathrm{~mm}$ long, $4.5 \mathrm{~mm}$ broad, hirsute. Cymes sessile; bracts conspicuous, up to $9 \mathrm{~mm}$ long, linear or lanceolate, densely long-hirsute. Flowers sessile; calyx long-hirsute, tube c. $1 \mathrm{~mm}$ long, lobes 5 narrowly triangular, c. $1 \mathrm{~mm}$ long, hirsute outside; corolla tube c. 4-5 $\mathrm{mm}$ long, glabrous, corolla lobes 5, c. $2 \mathrm{~mm}$ long, long-hirsute outside, floccose inside. Drupes subglobose c. $5 \mathrm{~mm}$ diam, hirsute; pyrenes 5 .

Distribution - Thailand, Malaysia (Peninsular, Borneo), Indonesia (Sumatra, Java).

Note - Lasianthus velutinus is almost the same as $L$. ellipticus except a little denser tomentose hairs which is not enough to separate it from the latter.

\section{Lasianthus eriocalyx H.Zhu, sp. nov. - Fig. 13}

Similis L. ferrugineus King \& Gamble, sed foliis longissimis, stipulis minutis $1 \mathrm{~mm}$ longis et lobis calycis 7-8 differt. - Typus: F.S.P. Ng s.n. KEP-FRI 22027 (holo L; iso K), Peninsular Malaysia, Ulu Trengganu, $900 \mathrm{~m}$ alt., in hillside primary forest, 26 Mar. 1974.

Treelet, c. $6 \mathrm{~m}$ high, crown spreading horizontally; branchlets terete, densely yellowish tomentose. Leaves: blades narrowly oblong-lanceolate, $23-25$ by $3-4 \mathrm{~cm}$, chartaceous, tomentose on both surfaces, apex acuminate to caudate, base acute to subrounded, midrib densely tomentose, prominent beneath, nerves flat above, prominent beneath, tomentose, 16-18 pairs, ascending at an angle of $60^{\circ}$, curved to margin, nervules obscure above, conspicuous beneath, reticulate, tomentose; petioles c. $5 \mathrm{~mm}$ long, tomentose. Stipules small, triangular, c. $1 \mathrm{~mm}$ long, tomentose. Inflorescences sessile; bracts absent. Flowers in fascicle, sessile; calyx densely tomentose, tube c. $2.5 \mathrm{~mm}$ long, lobes $7-8$, lanceolate, $3 \mathrm{~mm}$ long, $1 \mathrm{~mm}$ broad, densely tomentose external surface, sericeous internal surface; corolla not seen (from the description on the label of the type specimen, the corolla is whitish green, filled with hairs inside). Fruits not seen.

Distribution - Peninsular Malaysia.

Habitat \& Ecology — In montane primary forest. Flowering in March.

Note - This species is characterized by having very tomentose hairs on branchlets, leaves and calyx; leaves narrowly oblong-lanceolate, very long; calyx with 7-8 lanceolate lobes. This species is most similar to $L$. ferrugineus, but differs from the latter by having much longer leaves $(23-25 \mathrm{~cm}$ long), very small stipules ( $1 \mathrm{~mm}$ long) and calyx lobes 7-8. Lasianthus ferrugineus has leaves less than $18 \mathrm{~cm}$ long, stipules more than $3 \mathrm{~mm}$ long and calyx lobes 5 .

\section{Lasianthus euneurus Stapf}

Lasianthus euneurus Stapf (1894) 185; Merr. (1921) 577. - Type: Haviland 1119 (holo K; iso SING), Borneo, $7600 \mathrm{ft}$, in upper montane rainforests.

Shrubs to treelets, $2 \mathrm{~m}$ high; branchlets terete, c. $2 \mathrm{~mm}$ diam, densely pubescent. Leaves: blades elliptic or oblong-elliptic, $5-10$ by $1.5-4 \mathrm{~cm}$, coriaceous, glabrous except pubescence on midrib and nerves beneath, apex acute to acute-cuspidate, base acute, midrib and nerves flat or slightly prominent above, strongly prominent beneath, nerves $7-8$ pairs, ascending at an angle of $50-60^{\circ}$, curved to the margin, nervules distinct and nitid both surfaces, densely anastomosing, parallel; petioles 5-10 mm long, densely pubescent. Stipules subulate-triangular, c. $1 \mathrm{~mm}$ long, pubescent. Cymes sessile; bracts absent. Flowers sessile; calyx obconical to campanulate, c. $1.5 \mathrm{~mm}$ long pubescent outside, calyx limb truncate or minutely 4-toothed; corolla tube c. 3-4 mm long, puberulous outside, corolla lobes 4 , ovate, pubescent outside, floccose inside; anthers 4. Drupes subglobose, 2-3 $\mathrm{mm}$ diam, sparsely pubescent, 4-obtuseridged; pyrenes 4 .

Distribution - Malaysia (Borneo) and Indonesia (Sumatra).

\section{Lasianthus fasciculus H.Zhu, sp. nov. - Fig. 14}

Proximus $L$. euneuro Stapf, sed floribus 5-meris, calycibus 3-4 mm longis, lobis calycis triangulatis $1-1.5 \mathrm{~mm}$ longis, foliis $10-15 \mathrm{~cm}$ longis, nervis 9-11-binatis et nervulis supra obscuris differt. - Typus: Kessler PK32 (holo L), Sumatra, Kabulaten Tapanuli Utara Tele, $1650 \mathrm{~m}$ alt., in primary forest, 2 Dec. 1988

Treelet, c. 4-5 m high; branchlets compressed at the youngest part, densely appressed-pubescent. Leaves: blades oblong, $10-15$ by $3-5 \mathrm{~cm}$, subcoriaceous, glabrous above, pubescent venation beneath, apex acute, mucronate, base acute, margin recurved, midrib depressed above, strongly prominent beneath, nerves flat or slightly depressed above, prominent beneath, $9-11$ pairs, ascending at an angle of $60-70^{\circ}$, curved to margin, nervules obscure above, prominent beneath, parallel; petioles $1-1.5 \mathrm{~cm}$ long, densely appressed-pubescent. Stipules triangular, c. $1 \mathrm{~mm}$ long, densely appressed-pubescent. Inflorescences sessile; bracts inconspicuous. Flowers fascicular, sessile; calyx campanulate, 2-4 mm long, densely pubescent, lobes 5, triangular, 1-1.5 mm long, pubescent except margins external surface, tube 1.5-2 mm long, densely pubescent; corolla 6-7 $\mathrm{mm}$ long, lobes 5, triangular-lanceolate, c. $2 \mathrm{~mm}$ long, densely pubescent external surface, floccose internal surface, tube glabrous at the lower part. Fruits not seen.

Distribution - Indonesia (West Sumatra).

Habitat \& Ecology — In montane forests between 1650$2300 \mathrm{~m}$ altitude. Flowering during December and February.

Additional specimen examined. W Sumatra, Gunung Rasam, H. Nagamasu 3691 (L).

Note - This species is closely related to $L$. euneurus, but differs from the latter by having 5-merous flowers, calyx 3-4 $\mathrm{mm}$ long with triangular, $1-1.5 \mathrm{~mm}$ long lobes, leaves relatively big, $10-15$ by $3-5 \mathrm{~cm}$, with $9-11$ pairs of nerves, nervules obscure above. Lasianthus euneurus has 4-merous flowers, calyx $1-1.5 \mathrm{~mm}$ long with 4 minute teeth, leaves less than 10 $\mathrm{cm}$ long with 7-8 pairs of nerves, nervules conspicuous and prominent above.

\section{Lasianthus ferrugineus King \& Gamble}

Lasianthus ferrugineus King \& Gamble (1904) 130. - Type: Wray 3911 (holo SING; iso K), Peninsular Malaysia, Perak, $4500 \mathrm{ft}$.

Shrubs to treelets; c. $2 \mathrm{~m}$ high; branchlets terete, robust, c. 3 $\mathrm{mm}$ diam, densely brown-tomentose. Leaves: blades oblonglanceolate, $12-15$ by $2.5-3.5 \mathrm{~cm}$, subcoriaceous, tomentose on both surfaces but denser beneath, apex acuminate to caudate-acuminate, base broadly cuneate to subrounded, slightly asymmetric, dark-brown when dry, midrib dense browntomentose on both surfaces, prominent beneath, nerves 14-18 pairs, flat above, prominent beneath, ascending at an angle of c. $70^{\circ}$, curved to the margin, nervules obscure above, distinct beneath, reticulate; petioles c. $5 \mathrm{~mm}$ long, densely browntomentose. Stipules triangular, 3-4 mm long, densely browntomentose. Cymes sessile, bracts absent. Flowers sessile; calyx tubular-campanulate, densely tomentose, c. $3 \mathrm{~mm}$ long, with 5 lanceolate or subulate lobes; corolla not seen. Drupes subglobose, densely brown-tomentose, 3-4 mm diam; pyrenes $5-6$, verrucose on the abaxial face, thick-walled.

Distribution - Peninsular Malaysia. 


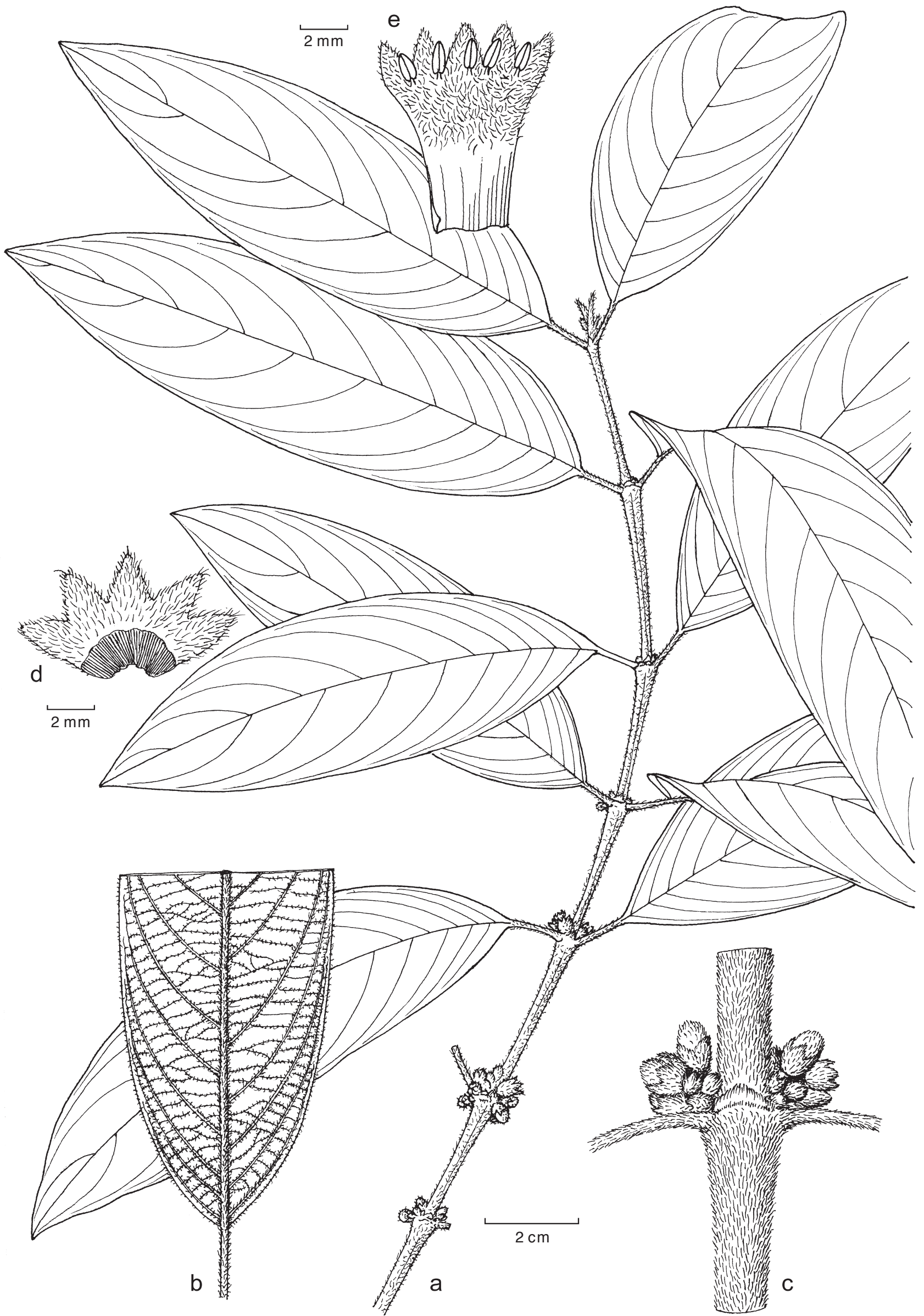

Fig. 14 Lasianthus fasciculus H.Zhu. a. Habit with inflorescences; b. lower surface of leaf showing parallel nervules; c. detail of node showing stipule and axillary inflorescences; d. calyx split opened; e. corolla split opened (all: P.J.A. Kessler PK32, holo L). 


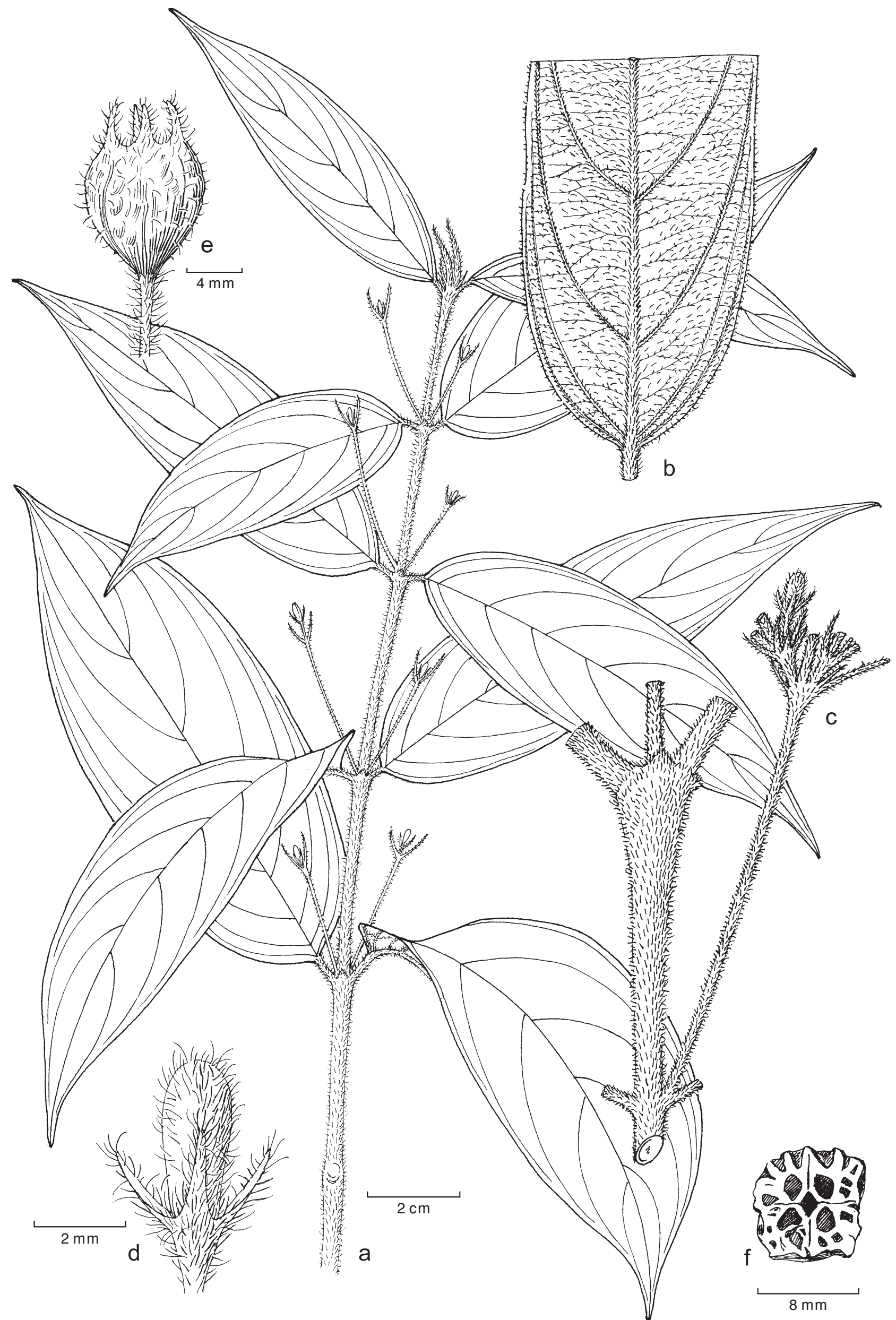

Fig. 15 Lasianthus filipedunculatus H.Zhu. a. Habit with inflorescences; b. detail of lower surface of leaf showing subparallel nervules and indumentum; c. detail of node; d. flower; e. fruit; f. cross section of fruit (all: I.M. Said et al. BRUN15640, holo L). 
Habitat \& Ecology — In upper montane rainforest. Flowering and fruiting in March and April.

Notes - This species is similar to L. pilosus, especially in the indumentum. Wong (1989) reduced L. ferrugineus to a synonym of $L$. pilosus. However, it differs from the latter by having leaves with broad-cuneate bases, longer petioles and shorter calyx lobes. We think it is better to keep it as a separate species.

This species differs from $L$. hirtus by having relatively small triangular stipules, oblong-lanceolate leaves $12.5-15 \mathrm{~cm}$ long, with 14-18 paired-nerves. From King, it differs from L. harveyanus King \& Gamble by having leaves sparsely hairy above, shorter hairy beneath, oblong-lanceolate, nerves 16-18; calyx with 5 deep lanceolate lobes; while the latter has leaves scabrid puberulous, elliptic to ovate-elliptic, nerves $4-6$ pairs, calyx narrowly campanulate.

\section{Lasianthus filiformis King \& Gamble}

Lasianthus filiformis King \& Gamble (1904) 131; Ridl. (1923a) 169; K.M.Wong (1989) 367. - Type: Scortechini 29 (lecto SING, designated by Wong 1989), Peninsular Malaysia, Perak; King 857 (para K), Peninsular Malaysia, Perak.

Lasianthus filiformis King \& Gamble var. bracteata King \& Gamble (1904) 131; K.M.Wong (1989) 367. - Type: Ridley 8578 (lecto SING, designated by Wong 1989), Peninsular Malaysia, Selangor; Scortechini 190 (para K), Peninsular Malaysia, Perak.

Slender shrubs, c. $1 \mathrm{~m}$ high; branchlets slender, c. $1.5 \mathrm{~mm}$ diam, spreading long-hairy. Leaves: blades oblong to oblonglanceolate, $5-7$ by $1.5-2 \mathrm{~cm}$, chartaceous, villous on both surfaces, apex acuminate or cuspidate-acuminate, base rounded to subcordate, oblique, midrib and nerves slender and slightly depressed above, prominent beneath, nerves 6-9 pairs, ascending at an angle of c. $45^{\circ}$, curved to the margin; nervules obscure above, distinct beneath, subparallel; petioles very short, c. $1 \mathrm{~mm}$ long, villous. Stipules linear, c. $4 \mathrm{~mm}$ long, villous. Cymes pedunculate; peduncles slender, filiform, $1-2.5 \mathrm{~cm}$ long, villous; bracts 1-2, leaf-like and ovate, or linear-lanceolate, 6-10 mm long, villous. Flowers sessile; calyx campanulate, villous, tube c. $2 \mathrm{~mm}$ long, lobes 4 , linear-lanceolate, c. $2 \mathrm{~mm}$ long; corolla tubular, villous, 4-lobed; ovary 8-locular. Drupes globose, c. $3 \mathrm{~mm}$ diam, sparsely long-hairy; pyrenes 6-8.

Distribution - Peninsular Malaysia.

Note - This var. bracteata differs from the typical variety by having only a little wider bracts which is not enough to recognize it as a variety.

\section{Lasianthus filipedunculatus H.Zhu, sp. nov. - Fig. 15}

A L. pendulo Ridl. ramulis foliis subtus pedunculis bracteis molliter tomentosis, costis et nervis supra leviter depressis vel planiusculis, petiolis $5 \mathrm{~mm}$ longis, capitulis cymae laxis, floribus 4-meris et pyrenis 4 differt. - Typus: BRUN 15640 (holo L), Brunei, Temburong, in primary dipterocarp forest, 17 July 1993.

Treelet; branchlets terete, robust, c. 2-3 mm diam, brownyellowish tomentose. Leaves: blades oblong-ovate to ovate, $10-15$ by $2.5-5 \mathrm{~cm}$, chartaceous to subcoriaceous, glabrous above, tomentose beneath, apex caudate to cuspidate, margin recurved, base rounded to subcordate, midrib flat to slightly depressed above, prominent beneath, 4-6 pairs, ascending at an angle of c. $60^{\circ}$, curved to margin, nervules obscure above, conspicuous beneath, subreticulate, tomentose beneath; petioles c. $5 \mathrm{~mm}$ long, densely tomentose. Stipules small, triangular, less than $2 \mathrm{~mm}$ long, densely tomentose. Inflorescences pedunculate; peduncles slender, $4-13 \mathrm{~cm}$ long, tomentose; bracts 2 in each node, thinly linear, 5-20 mm long, tomentose; bracteoles linear, relatively short, tomentose. Flowers 1-2 in each node, 4-merous, pediceled; pedicels c. $1 \mathrm{~mm}$ long; calyx densely tomentose, lobes 4 , linear, c. $2.5 \mathrm{~mm}$ long, tube short, obconical, c. $1 \mathrm{~mm}$ long; corolla c. $3 \mathrm{~mm}$ long, upper part external surface tomentose, lower part glabrous; stamens 4. Drupes subglobose, 7-8 mm diam, square in transverse section, warty, sparsely tomentose, conspicuously 4-ridged, crowned by 4 linear tomentose $5 \mathrm{~mm}$ long calyx lobes; pyrenes 4 , deeply sulcate on the abaxial face, subrhombic in transverse section.

Distribution - Endemic to Borneo: Brunei, Sabah.

Habitat \& Ecology — In primary forest of lower montane below $1200 \mathrm{~m}$ altitude. Flowering in July and fruiting in November.

Additional specimens examined. Sabah, Nabawan, F. Krispinus SAN 118556 (K, L), F. Krispinus SAN 118646 (K, L); Sabah, Pensiangan, A. Mantor SAN 136779 (L); Brunei, Temburong, D.A. Simpson 2201 (K, L), same locality, P.C. Bygrave 35 (L).

Notes - This species differs from $L$. pendulus by having soft and relatively short hairs on branches, leaves beneath, peduncles and bracts; leaf midrib and nerves slightly depressed or flat above, petioles c. $5 \mathrm{~mm}$ long; head of cymes less compact; flowers 4-merous; drupes with 4 pyrenes. Lasianthus pendulus has relatively long and stiff hairs on branches, leaves beneath, peduncles and bracts; leaf midrib and nerves deeply depressed above; petioles 1-2 mm long, head of cymes more compact; flowers 5-merous; drupes with 5 pyrenes.

This species is also related to $L$. robinsonii, but differs in having oblong-ovate to ovate leaves, nerves 4-6 pairs, petioles c. 5 $\mathrm{mm}$ long and stipules triangular less than $2 \mathrm{~mm}$ long. Lasianthus robinsonii has oblong leaves, nerves $8-9$ pairs, petioles $2-3$ $\mathrm{mm}$ and stipules triangular lanceolate, $4-5 \mathrm{~mm}$ long.

\section{Lasianthus flavinervius Ridl.}

Lasianthus flavinervius Ridl. (1915) 154; (1923a) 162. - Type: Ridley 16121 (holo SING; iso K), Peninsular Malaysia, Gunong Tahan, Pahang.

Shrubs; branchlets robust, terete, 3-4 mm diam, compressed and slightly sulcate in the youngest part, densely appressedpubescent. Leaves: blades oblong to oblong-elliptic, $10-15$ by 3-5 cm, coriaceous, glabrous above, appressed-pubescent on venation beneath, apex acuminate to cuspidate-acuminate, base acute or cuneate; midrib depressed above, strongly prominent beneath, nerves $6-8$ pairs, flat above, strongly prominent beneath, ascending at an angle of $50-60^{\circ}$, curved to the margin, nervules slightly prominent above, conspicuously prominent beneath, subparallel; petioles c. $1 \mathrm{~cm}$ long, densely appressed-pubescent. Stipules broadly triangular, c. $1.5 \mathrm{~mm}$ long, appressed-pubescent. Cymes sessile; bracts absent. Flowers sessile; calyx tubular-campanulate, 3-4 mm long, appressed-pubescent outside, lobes 5 , ovate-triangular, curved inward, c. 1-1.5 mm long, hirsute inside; corolla hirsute outside. Drupes campanulate, c. $5 \mathrm{~mm}$ long, crowned by 5 calyx lobes, pubescent, conspicuously 4-5-ridged; pyrenes 4-5.

Distribution - Peninsular Malaysia, Indonesia (Sumatra).

Notes - The species is very close to $L$. chinensis. It differs from the latter by having 6-8 pairs of nerves and somewhere subparallel nervules, midrib depressed above and strongly prominent beneath, nerves strongly prominent beneath.

Wong (1989) sank this species to L. perakensis. However, it differs from the latter by having midrib and nerves strongly prominent beneath, calyx tubular-campanulate with 5 ovatetriangular lobes, drupes campanulate crowned by 5 conspicuous calyx lobes, drupes with $4-5$ ridges. Lasianthus perakensis has midrib and nerves not strongly prominent beneath, calyx limb slightly trumpet-shaped with 5 indistinct obtuse lobes, drupes hemispheric with 10 obtuse ridges and crowned by obtuse calyx lobes. 


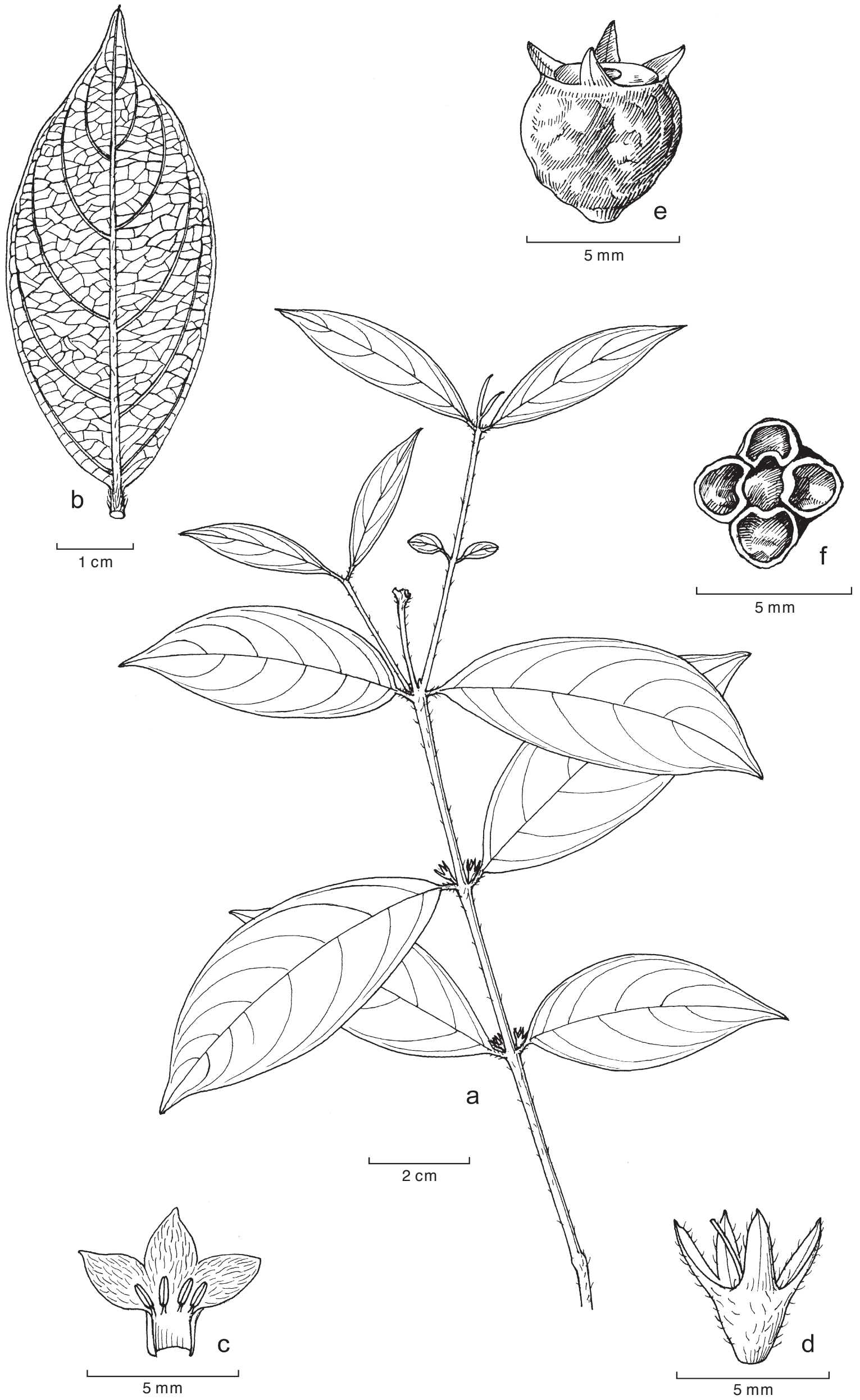

Fig. 16 Lasianthus floresensis H.Zhu. a. Habit with inflorescences; b. lower surface of leaf showing reticulate nervules; c. corolla split opened; d. calyx; e. fruit; f. cross section of fruit (all: J.A.J. Verheijen 2359, holo L). 


\section{Lasianthus floresensis H.Zhu, sp. nov. - Fig. 16}

Proximus L. fortulentus Ridsd., sed petiolis brevioribus c. 2 mm longis, cymis sessilis, lobis calycis oblongis $3 \mathrm{~mm}$ longis et pyrenis leviter verrucosis differt. - Typus: Verheijen 2359 (holo L), Lesser Sunda Islands, Flores, 22 Dec. 1996.

Shrub; branchlets terete, c. $1 \mathrm{~mm}$ diam, sparsely hirsute to glabrescent. Leaves: blades ovate-elliptic, $4-8$ by $2-3.5 \mathrm{~cm}$, subcoriaceous, glabrous or sparsely hirsute midrib and nerves beneath, apex acute, margin recurved, base acute to subrounded, midrib slightly prominent above, prominent beneath, nerves prominent on both surfaces, 4-5 pairs, ascending at an angle of $70-80^{\circ}$, curved, joining the veins above near leaf margin, forming an obscure intramarginal vein, nervules slightly prominent on both surfaces, weak, reticulate; petioles short, c. $2 \mathrm{~mm}$ long, sparsely hirsute or glabrescent. Stipules very small, triangular, c. $0.5 \mathrm{~mm}$ long. Inflorescences sessile; bracts absent. Flowers solitary, sessile; calyx campanulate, tube c. $1.5 \mathrm{~mm}$ long, puberulous, lobes 4 , oblong, c. $3 \mathrm{~mm}$ long, $1 \mathrm{~mm}$ broad, glabrous or sparsely puberulous; corolla $5 \mathrm{~mm}$ long, tube c. $2 \mathrm{~mm}$ long, glabrous, lobes 4 , ovate, 3 by $3 \mathrm{~mm}$, puberulous external surface, floccose internal surface. Drupes subglobose, glabrous, c. $5 \mathrm{~mm}$ diam, verrucose, with 4 conspicuous, obtuse ridges, crowned by persistent oblong calyx lobes; pyrenes 4 , slightly warty on the abaxial face, suborbicular in the transverse section.

Distribution — Indonesia: Java, Lesser Sunda Islands (Flores, Sumbawa), Moluccas.

Habitat \& Ecology - Flowering and fruiting in December.

Additional specimens examined. Lesser Sunda Islands, Sumbawa, herb Soembawa 194 (L); Java, J.H. Coert 1423 (L); Moluccas, Tanimbar, Jamdena, D.R. Pleyte $175(\mathrm{~L})$, P. Buwalda 4713 (K, L)

Note - This species is closely related to $L$. fortulentus Ridsd. from Ceylon. It differs from the latter by having shorter petioles (c. $2 \mathrm{~mm}$ long), cymes sessile, calyx lobes oblong, $3 \mathrm{~mm}$ long, and pyrenes slightly warty on the abaxial face; while $L$. fortulentus has petioles up to $1.5 \mathrm{~cm}$ long, cymes shortly pedunculate, calyx lobes triangular, 1-1.3 mm long, pyrenes conspicuously sulcate on the abaxial face.

\section{Lasianthus fordii Hance}

\section{Key to the varieties}

1. Leaves ovate-oblong, apex acuminate or cuspidate-acuminate . . . . . . . . . . . . . . . . . . . . . a. var. fordii

1. Leaves ovate, apex caudate ....... b. var. microphyllus

a. var. fordii - Map 6

Lasianthus fordii Hance (1885) 324; T.Yamaz. (1964) 352 (excl. var. pubescens (Matsum.) T.Yamaz.); T.S.Liu \& J.M.Chao (1964) 128, f. 7; H.Zhu (1994) 72; H.J.Li \& H.Y.Liu (1998) 284, pl. 126; H.S.Lo (1999) 97, pl. 25: 5-9; H.Zhu (2001b) 127; (2002) 98. - Type: Ford 66 (holo BM; iso K), China, Guangdong (Kwangdong), Lo Fu Shan.

Lasianthus tashiroi Matsum. (1901) 37. — Mephitidia tashiroi (Matsum.) Nakai (1922) 396. - Type: Uchiyama s.n. (n.v.).

Mephitidia tashiroi (Matsum.) Nakai var. kotoensis Nakai ex Sasaki (1928) 382, nom. nud.

Lasianthus zambalensis Elmer (1934b) 3209. - Type: Elmer 22045 (iso A, K, L, MO, NY, P, SING), Philippines, Luzon, Pampanga

Lasianthus kamputensis Pierre ex Pit. (1924) 392, p.p. quoad syntypes Eberhardt $2050(\mathrm{P})$, Pierre $3266(\mathrm{P})$.

Shrubs, 1-2 m tall; branchlets terete or compressed in the youngest part, c. $2 \mathrm{~mm}$ diam, glabrous to thinly appressedpubescent. Leaves: blades ovate-oblong, $6-10$ by $3-5 \mathrm{~cm}$, subcoriaceous or chartaceous, apex acuminate or cuspidateacuminate, base acute or obtuse, glabrous above, thinly appressed-pubescent or subglabrous beneath, midrib and nerves flat above, prominent beneath, nerves 4-6 pairs, ascending at an angle of $60-70^{\circ}$, curved to the margin, nervules usually obscure above, distinct beneath, subparallel; petioles up to $1 \mathrm{~cm}$ long, subglabrous to hirsute. Stipules minute, triangular, pubescent. Cymes sessile, bracts absent. Flowers sessile; calyx campanulate, sparsely pubescent, c. $2 \mathrm{~mm}$ long, with 5 triangular teeth; corolla 6-10 mm long, glabrous outside, villous inside, 5-lobed. Drupes globose or subglobose, 5-6 mm diam, glabrous; pyrenes 5-6.

Distribution - India (Northeast), China, Japan (Yakusima, Kyushu, Ryukyu), Vietnam, Cambodia, Thailand, Philippines (Luzon to Mindanao), Indonesia (Java, Sulawesi, Lesser Sunda Islands, Moluccas, Irian Jaya), Papua New Guinea.

Note - Lasianthus fordii is similar to L. lucidus and are often confused in herbaria. Lasianthus lucidus has small ovate to ovate-lanceolate leaves and lanceolate calyx lobes longer than

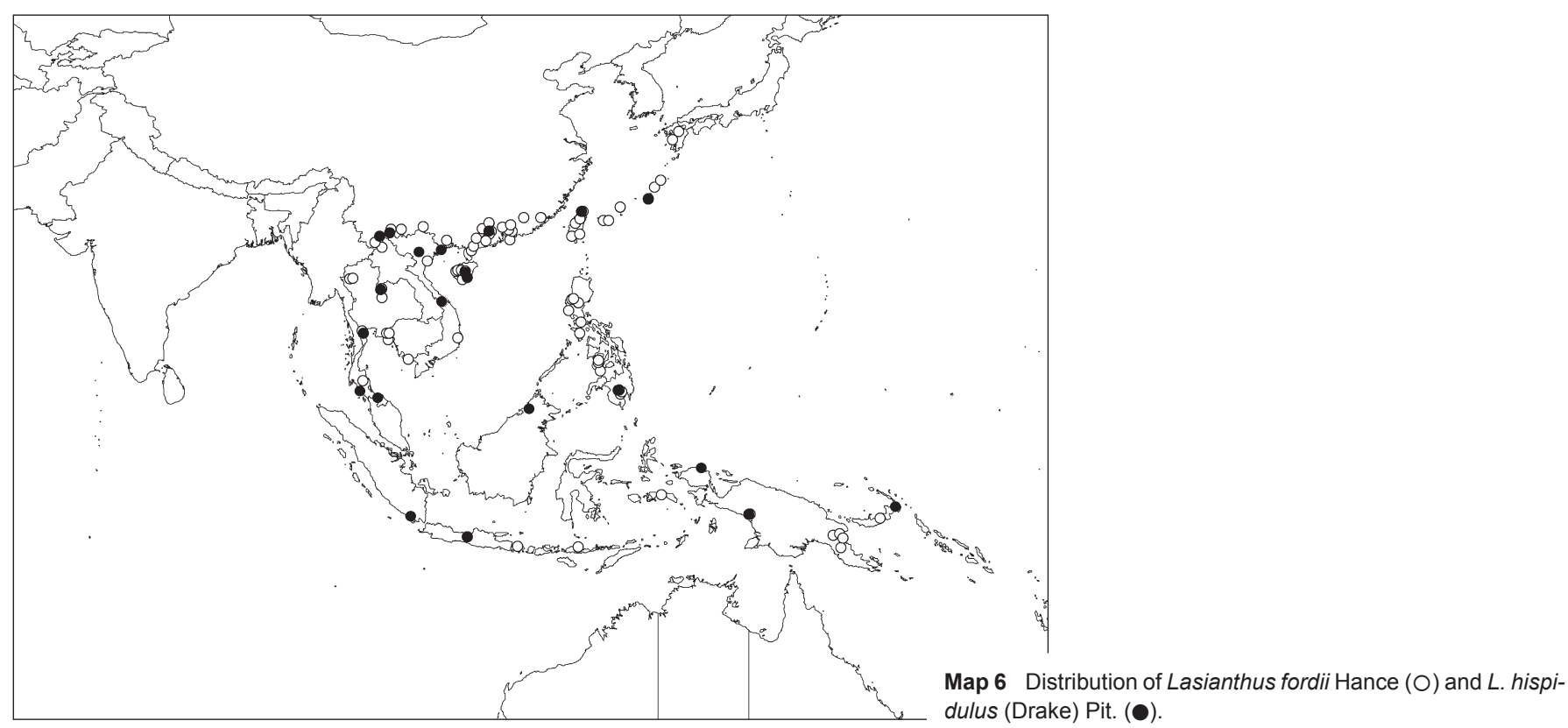




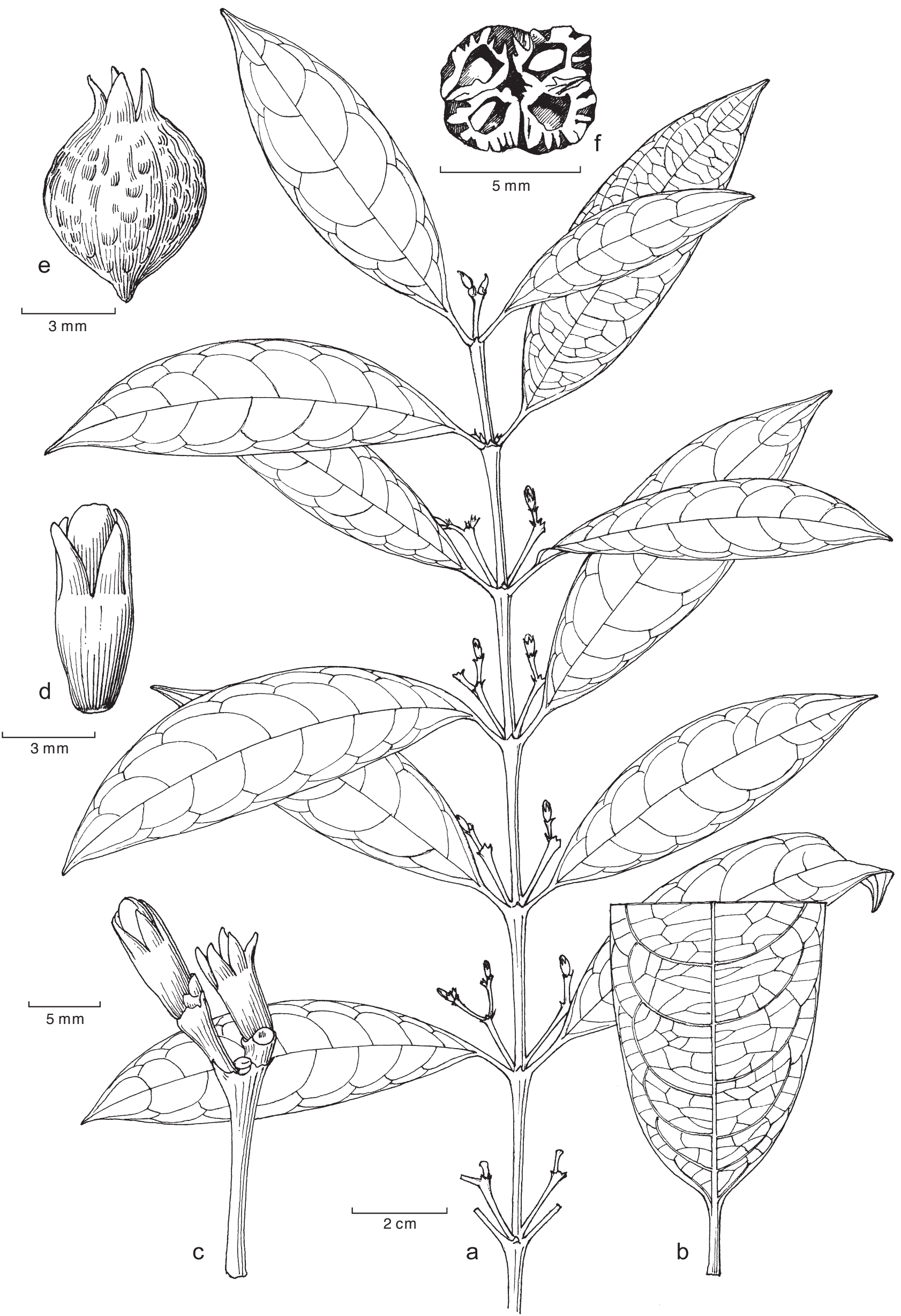

Fig. 17 Lasianthus furcatoides H.Zhu. a. Habit with inflorescences; b. lower surface of leaf showing reticulate nervules; c. detail of inflorescence; d. immature flower; e. fruit; f. cross section of fruit (all: llias Paie S.27239, holo L). 
tube, while L. fordii has leaves from small ovate-lanceolate to bigger ovate-oblong and minute triangular calyx lobes shorter than tube.

\section{b. var. microphyllus (Elmer) H.Zhu, stat. \& comb. nov.}

Lasianthus microphyllus Elmer, Leafl. Philipp. Bot. 5 (1913) 1870; Merr. (1923) 566. - Typus: Elmer 13790 (iso A, CAS, E, K, L, MO, U, US), Philippines, Mindanao, Mt Urdaneta, $6500 \mathrm{ft}$, mossy forest.

Shrubs, branchlets subglabrous to glabrous. Leaves relatively small, ovate, apex caudate. Calyx glabrous. Drupes globose, crowned by minute calyx teeth.

Distribution - The Philippines.

Note - Lasianthus microphyllus is very closely related to $L$. fordii. It differs from $L$. fordii only by having usually much small ovate leaves with a caudate apex which is too weak to recognize it as a separate species. We here sink it to a variety of $L$. fordii.

\section{Lasianthus foxworthyanus Craib}

Lasianthus foxworthyanus Craib (1933) 21; (1934) 211; K.M.Wong (1989) 369; H.Zhu (2001b) 129. - Type: Kiah 24312 (holo BK; iso KEP, SING), Thailand, Pattani.

Shrubs, up to $3 \mathrm{~m}$ high; branchlets terete, c. $1.5-2 \mathrm{~mm}$ diam, densely appressed-pubescent. Leaves: blades oblong, oblonglanceolate or oblong-elliptic, $9-16$ by $3-5 \mathrm{~cm}$, thinly coriaceous, glabrous above, appressed-pubescent on venation beneath, apex acuminate, aristate at summit, base cuneate, midrib slightly depressed above, prominent beneath, nerves 6-9 pairs, flat or slightly prominent above, conspicuously prominent beneath, nervules distinct on both surfaces, parallel; petioles 5-7 mm long, appressed-pubescent. Stipules triangular, 4-5 mm long, appressed-pubescent. Cymes sessile; bracts appressed-pubescent, outer ones lanceolate, up to $5 \mathrm{~mm}$ long, inner ones smaller, linear to subulate. Flowers not seen. Drupes globose, c. $5 \mathrm{~mm}$ diam, puberulous or subglabrous, crowned by appressed-pubescent calyx limbs, with 4 obtuse ridges; pyrenes 4.

Distribution — Thailand, Peninsular Malaysia.

\section{Lasianthus furcatoides H.Zhu, sp. nov. - Fig. 17}

Proximus L. laevigato Blume, sed foliis venationibus brachidodromibus, nervis 4-5, stipulis subulatis minutis, lobis calycis et corollis 4, pyrenis 4 conspicue verrucosis differt. - Typus: Ilias Paie S.27239 (holo L; iso K), Sarawak, Ulu Segan, Bintulu, $600 \mathrm{ft}$ alt., hillside, 27 Aug. 1968.

Shrub, 1.3-2 m high; branchlets robust, usually compressed, c. $3 \mathrm{~mm}$ diam, glabrous, yellowish. Leaves: blades oblong, 7-13 by $2-4.5 \mathrm{~cm}$, membranaceous, glabrous on both surfaces, apex cuspidate, base cuneate, midrib slightly prominent above, conspicuously prominent beneath, nerves slightly prominent on both surfaces, 4-7 pairs, ascending at an angle of almost $90^{\circ}$, curved near the leaf margin and joining the veins above forming an intramarginal vein, internerved veins conspicuous, ascending from the midrib at a nearly right angle, combination to the main nerves, nervules slightly prominent on both surfaces, reticulate; petioles $0.5-1 \mathrm{~cm}$ long, glabrous. Stipules very small, subulate-triangular, less than $1 \mathrm{~mm}$ long, glabrous. Inflorescences pedunculate; peduncles $0.5-1.5 \mathrm{~cm}$ long, furcate, glabrous except sparse bristles at nodes, flattened at base and nodes; bracts subulate, c. $1 \mathrm{~mm}$ long, puberulous or glabrous; bracteoles subulate to ovate, less than $1 \mathrm{~mm}$ long. Flowers sessile, articulate; calyx obconical, up to $8 \mathrm{~mm}$ long, glabrous, tubes $2.5-3 \mathrm{~mm}$ long, lobes 4 , triangular-lanceolate or oblong-lanceolate, up to $5 \mathrm{~mm}$ long; corolla as long as calyx, lobes 4 , sparsely puberulous external surface, floccose internal surface; stamens 4, adhering on corolla tube; ovary 4-locular. Drupes oblong, c. $5 \mathrm{~mm}$ diam, glabrous, verrucose, crowned by lanceolate calyx lobes; pyrenes 4, very warty on abaxial face. Distribution - Endemic to Borneo (Sarawak).

Habitat \& Ecology — In forest between 600-2300 ft. Flowering and fruiting between August and December. (L).

Additional specimen examined. Sarawak, Bakam, Abg. Mohtar S.47207

Note - This species is characterized by its glabrous plants, looped leaf venation, and furcate peduncles. It is closely related to $L$. laevigatus, but differs in having leaves with looped venation; nerves $4-5$ pairs; stipules very small, subulate, less than $1 \mathrm{~mm}$ long; calyx and corolla lobes 4; drupes with 4 pyrenes; pyrenes very warty. Lasianthus laevigatus has leaves without looped venation; nerves 8-10; stipules triangular, $4 \mathrm{~mm}$ long; calyx and corolla lobes 5-6; drupes with 6 pyrenes; pyrenes much more smooth.

\section{Lasianthus glaber Ridl}

Lasianthus glaber Ridl. (1911; nec 1910) 59; (1923a) 155; K.M.Wong (1989) 373, p.p. - Type: Ridley 11486 (14490 in publication) (holo SING; iso K), Peninsular Malaysia, Temengoh.

Shrubs; branchlets terete, sometimes compressed in the youngest part, glabrous, dark-brown when dry. Leaves: blades elliptic, elliptic-lanceolate, thinly coriaceous, $15-18$ by $4-5 \mathrm{~cm}$, glabrous on both surfaces, apex cuspidate-acute, base acute, midrib depressed above, prominent beneath, nerves 6-7 pairs, flat above, prominent beneath, ascending at an angle of $70-80^{\circ}$, curved to the leaf margin, nervules slender, distinct on both surfaces, subparallel; petioles 5-10 mm long, glabrous. Stipules big, ovate-triangular to triangular-lanceolate, $8-9 \mathrm{~mm}$ long, $5 \mathrm{~mm}$ broad at base, glabrous except the sparsely ciliate margin. Cymes sessile; bracts numerous, glabrous except long-ciliate hairs at the margin, outer ones similar to stipules, ovate-triangular, 7-8 mm long, inner ones smaller, lanceolate. Flowers sessile; calyx campanulate, tube c. $1.5 \mathrm{~mm}$ long, glabrous, limb with 5 broadly triangular lobes, glabrous outside, long-ciliate inside and at margin, lobes c. $1 \mathrm{~mm}$ long; corolla glabrous outside, tube $6-7 \mathrm{~mm}$ long, lobes 5 , oblong, c. $3 \mathrm{~mm}$ long. Drupes subglobose, c. $5 \mathrm{~mm}$ diam, the base narrowed, with 4-5 obtuse ridges; pyrenes 4-5.

Distribution - Peninsular Malaysia.

Notes - The specimen Ridley 11486 from Temenggo of Perak in SING that has the name L. glaber written on the label in Ridley's handwriting, is annotated as the type of $L$. glaber. Although it is not Ridley 14490 in publication, it agrees with Ridley's description.

This species is similar to $L$. stipularis. It differs from $L$. stipularis by having ovate-lanceolate stipules and ovate-triangular to lanceolate bracts, 7-8 mm long, with hairs at margin. Lasianthus stipularis has linear to narrowly lanceolate bracts which are villous and up to $1.5 \mathrm{~cm}$ long.

\section{Lasianthus griffithii Wight}

\section{Key to the varieties}

1. Branchlets glabrous to stiffly hirsute; leaves glabrous to sparsely hirsute, nervules slightly prominent beneath . . . . . . .

. . . . . . . . . . . . . . . var. griffithii

1. Branchlets completely glabrous; leaves with stiffing hairs on both surfaces, nervules conspicuously elevated beneath . b. var. scabridus 


\section{a. var. griffithii}

Lasianthus griffithii Wight (1846) 505; Hook.f. (1880) 179; King \& Gamble (1904) 111; Merr. (1921) 577; Ridl. (1923a) 152; K.M.Wong (1989) 371. — Type: Kew Dist. 2935 (Griffith s.n.) (holo K), Peninsular Malaysia.

Lasianthus spathulatus Miq. (1869) 246, syn. nov. - Type: Vriese \& Teysmann s.n. (holo L, barcode L0057497), Borneo.

Lasianthus polycarpus Miq. (1869) 247; Merr. (1921) 579; (1929a) 292; (1937) 298, syn. nov. - Type: Vriese \& Teysmann s.n. (holo L, barcode L0057500), Borneo.

Lasianthus griffithii Wight var. latibracteata King \& Gamble (1904) 112. Syntypes: Ridley 10196 (n.v.), Selangor; Ridley 9528 (n.v.), Perak; Scortechini 6172 (iso K)

Treelets, up to $5 \mathrm{~m}$ high; branchlets terete, robust, c. 3-4 mm diam, glabrous to more or less stiffly hirsute, dark-brown when dry. Leaves: blades oblong-lanceolate, obovate to obovate-lanceolate, $18-25$ by $4-9 \mathrm{~cm}$, coriaceous, glabrous to sparsely hirsute above, glabrous to densely hirsute beneath, apex cuspidate to caudate-cuspidate, margin often reflexed, base cuneate to acuminate, midrib and nerves flat to slightly prominent above, prominent beneath, nerves 12-20 pairs, usually ascending at an angle of over $50^{\circ}$, curved to the margin, nervules obscure to prominent above, prominent beneath, reticulate; petioles 1-2 cm long, glabrous to hirsute. Stipules big, partly covering the cymes, ovate to triangular-ovate or broadly triangular, 1-2 by 1-2 cm, coriaceous with membranaceous margin, usually glabrous. Inflorescences sessile; bracts numerous, linear, hirsute, forming a dense head. Flowers sessile, sealed (hidden) by bracts; calyx tube obconic, c. $2 \mathrm{~mm}$ long, glabrous, calyx limb funnel-shaped, 3-4 mm long, glabrous outside, hirsute inside, calyx lobes usually 6 , ovate-triangular, c. $2 \mathrm{~mm}$ long, glabrous outside, densely hirsute inside, or hirsute both sides; corolla short, c. 4-5 mm long, glabrous outside, hairy inside. Drupes turbinate-ellipsoid, c. $1 \mathrm{~cm}$ long, the base narrowed, the apex crowned by a cupular calyx limb, glabrous except the calyx limb; pyrenes usually 6 .

Distribution - Malaysia (Peninsular, Borneo), Indonesia (Sumatra).

Notes - Lasianthus griffithii has large obovate-elliptic leaves (glabrous to hairy), large broad-triangular stipules, flowers densely covered by numerous filiform to lanceolate bracts with dense hairs outside, calyx with 5-7 triangular hairy lobes, drupes teethed. Lasianthus polycarpus is just the same species as $L$. griffithii. Lasianthus spathulatus differs from $L$. griffithii by having only relatively narrow, so-called spathulate leaves, which is not enough to separate it from the latter. Wong (1989) sank L. griffithii var. latibracteata.

Lasianthus griffithii is quite variable in leaf sizes and indumentum. It has leaves from relatively narrow spathulate to obovate, from $15 \mathrm{~cm}$ long to $35 \mathrm{~cm}$ long, most are oblong-obovate and $18-25 \mathrm{~cm}$ long. It is glabrous on branches, leaves and stipules to tomentose or hirsute hairs on leaves beneath, branches and leaves beneath or whole plant.

\section{b. var. scabridus (King \& Gamble) H.Zhu, stat. nov.}

Lasianthus scabridus King \& Gamble, J. Asiat. Soc. Bengal 73 (1904) 111; Ridl. (1923a) 152; K.M.Wong (1989) 370. — Typus: Ridley 6463 (lecto SING, designated by Wong 1988), Peninsular Malaysia, Johore.

Branchlets terete, robust, glabrous, dark-brown when dry. Leaves: blades oblong-lanceolate to obovate-lanceolate, with stiff hairs on both sides; nervules reticulate, conspicuously prominent beneath. Stipules big, partly covering the cymes, ovate to triangular-ovate or broadly triangular, $1-2$ by 1-2 $\mathrm{cm}$, coriaceous with membranaceous margin, glabrous. Inflorescences sessile; bracts numerous, linear, hirsute, forming a dense head. Flowers sessile, sealed (hidden) by bracts.
Distribution - Malaysia (Peninsular, Borneo), Indonesia (Sumatra, Kalimantan).

Note - Lasianthus scabridus differs from L. griffithii in having stiff hairs on both sides of leaves, reticulate nervules conspicuously prominent beneath. It is suitable to $\operatorname{sink} L$. scabridus to a variety of $L$. griffithii as var. scabridus.

\section{Lasianthus hexandrus (Blume) Blume}

Lasianthus hexandrus (Blume) Blume (1826-1827) 998; Miq. (1857) 323 (1869) 249. - Mephitidia hexandra Blume (1823) 51. - Type: Blume s.n. (lecto L, designated here, barcode L0310418). Paratypes: Blume s.n. (L, barcode L0310419), Blume s.n. (L, barcode L0310420), Java, Salak.

Shrubs to treelets, up to $2.5 \mathrm{~m}$ high; branchlets terete, slender, c. $1 \mathrm{~mm}$ diam, densely appressed-hirsute. Leaves: blades lanceolate, $4-9$ by $1-2 \mathrm{~cm}$, subcoriaceous, glabrous above except hirsute midrib, pubescent beneath, apex acuminate to caudate-acuminate, base acute to obtuse, nerves relatively slender, flat or slightly depressed above, prominent beneath, 6-7 pairs, ascending at an angle of $70-80^{\circ}$, curved to the margin, nervules obscure above, slender and distinct beneath, subparallel; petioles 3-4 mm long, densely appressed-hirsute. Stipules triangular, 1.5-2 mm long, densely appressed-hirsute. Cymes sessile; bracts absent. Flowers usually solitary; calyx tubular-campanulate, hirsute, divided near to the base, tube c. $1.5 \mathrm{~mm}$ long, lobes 4-6, oblong-lanceolate, c. $3 \mathrm{~mm}$ long, long-hirsute outside, glabrous inside; corolla not seen. Drupes subglobose, c. $4 \mathrm{~mm}$ diam, hirsute, 4-obtuse-ridged, crowned by oblong-lanceolate calyx lobes; pyrenes 4 .

Distribution - Indonesia (Java, Sumatra, Kalimantan).

Notes - This species has appressed-hirsute hairs on branches, leaves beneath, leaf midrib above and calyx, lanceolate leaves with an acuminate apex and acute base, calyx divided near to the base (lobes lanceolate longer than tube, just like L. curtisii), hirsute drupes crowned by oblong-lanceolate calyx lobes. According to Blume (1826-1827), this species has 6-merous flowers (hexandrus). According to Miquel (1869), the flowers are 5-merous. In our observation (Sumatra, J.A. Lörzing 11395), it has 4-6 oblong-lanceolate calyx lobes, drupes with 4 pyrenes.

Lasianthus hexandrus differs from $L$. curtisii by having appressed-hirsute hairs on branches, leaves beneath and leaf midrib above, lanceolate leaves and drupes with 4 pyrenes. Lasianthus curtisii has spreading villose hairs on branches and leaves beneath, leaf midrib glabrous above, leaves oblong or ovateoblong, drupes with 5 pyrenes. Lasianthus hexandrus differs from $L$. chrysotrichus in having appressed-hirsute hairs on branchlets and leaf nerves beneath. Lasianthus chrysotrichus has spreading hirsute hairs on branches and leaves nerves beneath.

\section{Lasianthus hirsutisepalus H.Zhu, sp. nov.}

Proximus L. appresso Hook.f., sed nervis rare hirsutis subtis, nervulis reticulates, calycibus dense hirsutis, lobis calycis ovato-triangulatis dense hirsutis et pyrenis 4 differt.- Typus: Tong et al. S.32936 (holo K), Malaysia (Borneo), Ulu Sg. Masia, 4700 ft, 13 Mar. 1973.

Shrub, c. $3 \mathrm{~m}$ high; branches and branchlets terete, densely appressed-hirsute. Leaves: blades relatively small, lanceolate, $6-8$ by $1.5-2 \mathrm{~cm}$, subcoriaceous, pale shining and glabrous above when dry, hirsute on midrib and sparsely hirsute on nerves beneath, apex acute to acuminate, base acute to cuneate, midrib slightly depressed above, prominent beneath, nerves flat above, prominent beneath, 5 pairs, ascending at an angle of $30-40^{\circ}$, curved to the margin, nervules conspicuous, prominent on both sides, reticulate; petioles $5-10 \mathrm{~mm}$ 
long hirsute. Stipules triangular, c. $1 \mathrm{~mm}$ long, hirsute. Cymes sessile; bracts inconspicuous. Flowers sessile; calyx campanulate, densely hirsute on outside, tube c. $2 \mathrm{~mm}$ long, lobes 4 , ovate-triangular, 1.5-2 mm long, densely hirsute both sides; corolla not seen. Drupes small, $3 \mathrm{~mm}$ diam, globose, crowned by the ovate-triangular calyx lobes, hirsute; pyrenes 4 , smooth on abaxial face.

Distribution - Endemic to Borneo.

Habitat \& Ecology - Flowering March.

Note - This species differs from $L$. appressus in having sparse hirsute hairs on nerves beneath, nervules reticulate; calyx densely hirsute, lobes ovate-triangular, densely hirsute on both sides; drupes with 4 pyrenes.

\section{Lasianthus hirsutus (Roxb.) Merr. - Map 7}

Lasianthus hirsutus (Roxb.) Merr. (1952) 229; Bakh.f. (1965) 339; Deb \& M.Gangop. (1991) 282, f. 4; H.Zhu (1994) 58; H.S.Lo (1999) 79; H.Zhu (2001b) 129; (2002) 76. - Triosteum hirsutum Roxb. (1824) 180. - Type: Unknown collector, sp.no: 139 (holo BM), Chittagong.

Lasianthus bracteatus Wight (1846) 501. - Type: Griffith s.n. (n.v.), Peninsular Malaysia.

Lasianthus roxburghii Wight (1846) 502. - Type not designated.

Lasianthus oculus-cati Miq. (1857) 315; (1869) 249. - Type: Unknown collector s.n. (holo L, barcode L0057762), Java.

Lasianthus laevicaulis Kurz (1875) 327. - Type: Kurz s.n. (iso K), Nicobar Island.

Lasianthus everettii Merr. (1908a) 265. - Type: Everett s.n. FB. 5591 (lost), Philippines, Negros Occidental.

Lasianthus cyanocarpus Jack var. novoguineensis Valeton (1911) 498; Merr. \& L.M.Perry (1946) 219, syn. nov. - Type: Versteeg 1406 (iso L), SW New Guinea.

Lasianthus cyanocarpus Jack var. asperatus Pierre ex Pit. (1924) 381. Type: Pierre 3256 (syn P; isosyn. L), Bien Hoa.

Lasianthus cyanocarpus Jack var. lucidus Pierre ex Pit. (1924) 382. — Syntypes: Pierre s.n. (P; isosyn. L), Vietnam, Bien Hoa; Harmand s.n. (P), Condor.

Lasianthus cyanocarpus auct. non Jack: Blume (1826-1827) 996; Benth. (1861) 160; Kurz (1877) 32; Hook.f. (1880) 179; Hemsl. (1888) 388; King \& Gamble (1904) 113; Merr. (1921) 578; Pit. (1924) 381; Ridl. (1923a) 153; Craib (1934) 210; H.L.Li (1944) 430; T.S.Liu \& J.M.Chao (1964) 129, f. 6; K.M.Wong (1989) 370; H.J.Li \& H.Y.Liu (1998) 280, pl. 125.

Shrubs, 1-2 m high, usually stiff spreading rusty-hirsute; branchlets terete, robust, c. $3 \mathrm{~mm}$ diam, dark-brown when dry. Leaves: blades oblong or oblanceolate-oblong, $13-20$ by $5-6 \mathrm{~cm}$, subcoriaceous or coriaceous, apex acuminate, base acute, darkbrown when dry, midrib and nerves flat to slightly depressed above, prominent beneath, nerves 7-10 pairs, ascending at an angle of $70-80^{\circ}$, curved to the margin, nervules slender, obscure above, prominent beneath, subparallel; petioles 10-15 $\mathrm{mm}$ long, hirsute. Stipules lanceolate or triangular-lanceolate, 8-10 mm long, densely hirsute. Cymes sessile, covered with many persistent leafy bracts, outer ones ovate-lanceolate, 2-3 $\mathrm{cm}$ long, with distinct nerves, inner ones linear, mach smaller, all hirsute on both surfaces. Flowers sessile, calyx obconical, densely long-hirsute, with 5 linear-lanceolate lobes, tube c. 1 $\mathrm{mm}$ long, lobes 5 , c. $2.5 \mathrm{~mm}$ long, long-hirsute; corolla tube c. $1-1.2 \mathrm{~cm}$ long, glabrous in the lower half, hirsute in the upper half, glabrous inside, lobes 5, ovate, c. $3 \mathrm{~mm}$ long. Drupes ovoid-globose, hirsute to glabrous, crowned by the hirsute calyx lobes; pyrenes 5.

Distribution - India, Bangladesh, Burma, China, Japan (Ryukyu), Vietnam, Laos, Cambodia, Thailand, Malaysia (Peninsular, Borneo), Philippines, Indonesia (Sumatra, Java, Kalimantan, Moluccas, Irian Jaya), Papua New Guinea.

Note - Lasianthus hirsutus is a widely distributed species. It differs conspicuously from other species of the genus mainly by its usually stiff rusty-hirsute hairs and cymes covered with many persistent large leafy bracts. This species is easily recognized. However, it was mistakenly called $L$. cyanocarpus by most authors. Although Merrill (1952) showed that the correct name of the species is $L$. hirsutus, the misapplied name $L$. cyanocarpus has subsequently been used by many authors. The species $L$. cyanocarpus is clearly different from $L$. hirsutus. Lasianthus cyanocarpus has relatively smaller leaves with cordate and a slightly oblique base, usually fewer and relatively small bracts. Lasianthus hirsutus differs from it in relatively large leaves with cuneate, slightly unequal base, relatively long petioles, conspicuous triangular stipules, more numerous bracts, outer ones ovate-oblong, leaf-like, inner ones gradually narrower and smaller, as well as usually long rusty-hirsute hairs on plants.

\section{Lasianthus hirtimarginatus H.Zhu, sp. nov.}

Similis $L$. angustifolio King \& Gamble, sed ramulis glabris, foliis dense hirsutis ad marginem, nervis $8-11$ binatis et petiolis longioribus differt. - Typus: Hotta \& Tamin 201 (holo L), W Sumatra, Padang, 1300 m alt., 23 Jan. 1981.

Shrub, $3 \mathrm{~m}$ high; branchlets slightly compressed, glabrous, c. 2 $\mathrm{mm}$ diam, lenticellate. Leaves: blades lanceolate, $12-17$ by $1.5-2.5 \mathrm{~cm}$, chartaceous, glabrous above, puberulous or glabrescent beneath except pubescent midrib and nerves, apex long caudate, margin densely hirsute, base acute, slightly asymmetric, midrib slightly depressed above, prominent beneath,

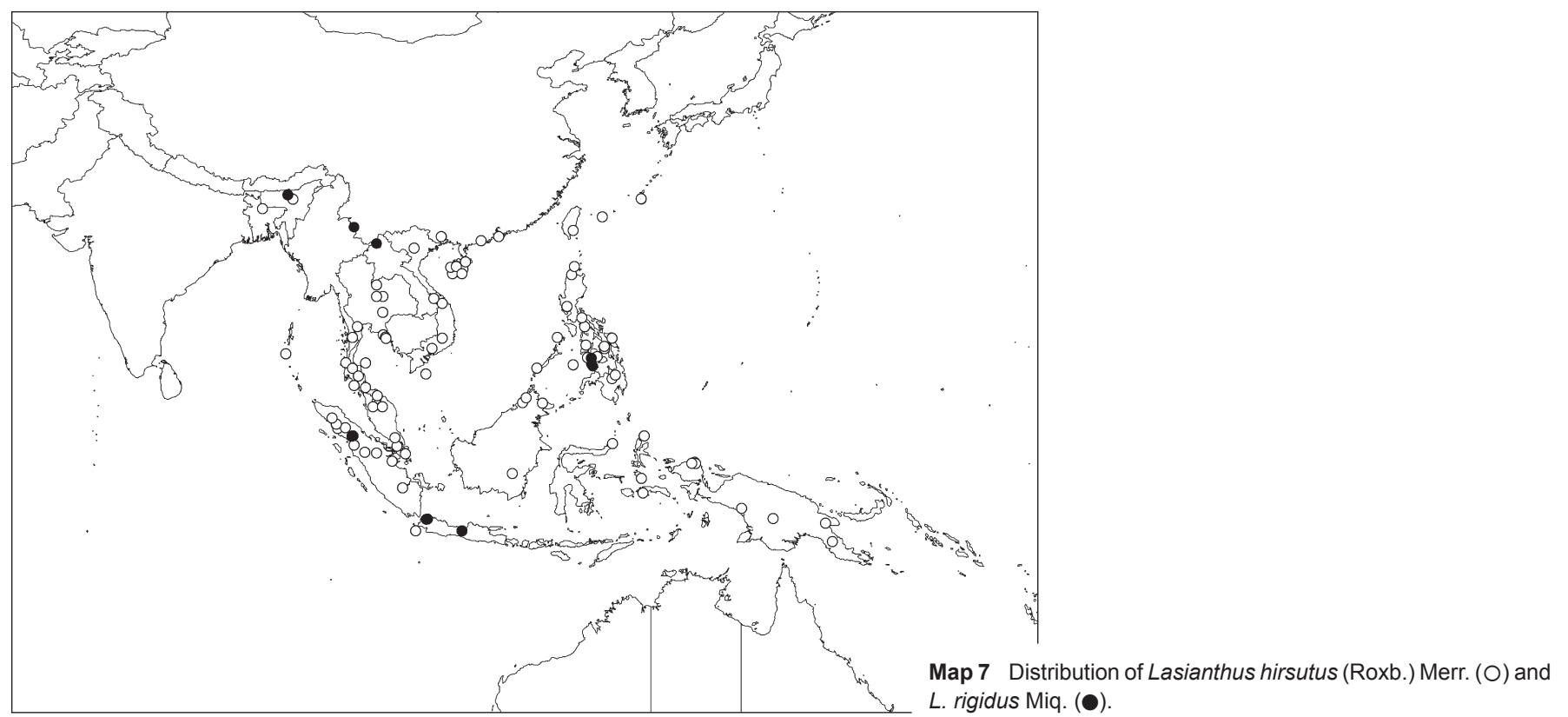

L. rigidus Miq. (๑). 
nerves flat above, prominent beneath, 8-11 pairs, ascending at an angle of $70-80^{\circ}$, curved to the margin, nervules obscure above, slightly clear beneath, reticulate, puberulous beneath; petioles $1.2-1.5 \mathrm{~cm}$ long, glabrous. Stipules triangular, c. 2 $\mathrm{mm}$ long, hirsute. Inflorescences sessile; bracts inconspicuous. Flowers sessile; calyx pubescent, with 4-5 minutely teeth; corolla pubescent. Drupes c. $5 \mathrm{~mm}$ diam, warty, irregular ridged, pubescent; pyrenes $4-5$.

Distribution - Indonesia (Sumatra).

Habitat \& Ecology - In lower montane forests between $1100-1500 \mathrm{~m}$ altitude in W Sumatra. Flowering and fruiting between January and August. (L)

Additional specimen examined. W Sumatra, Padang, H. Nagamasu 3140

Note - This species is similar to $L$. angustifolius. It differs from the latter by having glabrous branchlets, densely hirsute leaf margin, nerves $8-11$ pairs and longer petioles $(1.2-1.5 \mathrm{~cm}$ long); while $L$. angustifolius has pubescent branchlets, glabrous leaf margin, nerves $12-14$ pairs and short petioles $(4-5 \mathrm{~mm}$ long).

\section{Lasianthus hirtus Ridl.}

Lasianthus hirtus Ridl. (1909) 36; (1923a) 153. - Type: Ridley 14009 (holo SING; iso K), Peninsular Malaysia, Pahan.

Lasianthus acutatus auct non Miq.: Bakh.f. (1965) 341.

Shrubs, $2 \mathrm{~m}$ high; branchlets terete, c. $2 \mathrm{~mm}$ diam, densely spreading brown-pilose. Leaves: blades oblong-lanceolate, $6-9$ by $2-2.5 \mathrm{~cm}$, thinly coriaceous, densely pilose on both surfaces, apex caudate to caudate-acuminate, base acute to subrounded, midrib and nerves depressed above, prominent beneath, nerves $8-9$ pairs, ascending at an angle of c. $50^{\circ}$, curved to the margin, nervules obscure above, distinct beneath, subparallel; petioles $2-4 \mathrm{~mm}$ long, densely spreading brown-pilose. Stipules ovate, 3-4 mm long, membranaceous, densely pilose. Cymes sessile; bracts absent. Flowers sessile; calyx campanulate, dense pilose, tube c. $1 \mathrm{~mm}$ long, lobes 5 , subulate-lanceolate, c. $1.5 \mathrm{~mm}$ long, densely long-pilose; corolla c. 7-8 mm long, pilose outside, lobes 5, lanceolate. Drupes ellipsoid, c. $4 \mathrm{~mm}$ long, sparsely pilose to densely pilose, with 5 obtuse ridges, crowned by densely pilose calyx limbs; pyrenes 4 , smooth on the abaxial face.

Distribution - Peninsular Malaysia, Indonesia (Sumatra, Java, Sulawesi).

Notes - This species is close to $L$. acutatus but differs from it by having dense spreading pilose hairs on branches, leaves, petioles, stipules and calyx; leaves relatively small $(6-9 \mathrm{~cm}$ long); stipules ovate. Lasianthus acutatus has stiff hairs on branches, leaves, and stipules, relatively bigger leaves that are $12-17 \mathrm{~cm}$ long, linear-lanceolate stipules.

Lasianthus hirtus has ovate and membranaceous stipules, the same as $L$. stercorarius, but differs from the latter by having dense spreading pilose hairs on branches, leaves, petioles, stipules, and calyx; calyx with 5 subulate-lanceolate lobes; drupes with 5 pyrenes.

Lasianthus hirtus was reduced to a synonym of $L$. pilosus by Wong (1989). However, it conspicuously differs from $L$. pilosus by having leaf blades relatively small $(6-9 \mathrm{~cm}$ long) and with less nerves and acute to subrounded base; stipules ovate; bracts absent; calyx lobes subulate-lanceolate, relatively short, c. $1.5 \mathrm{~mm}$ long. Lasianthus pilosus has leaves relatively large (10-17 cm long) with usually rounded unequal base and more nerves; stipules triangular-lanceolate; bracts subulate; calyx lobes filiform, relatively long.

Lasianthus hirtus could be conspecific to L. rufus (Korth.) Miq., because it almost agrees with Korthals' (1851) description.
Without seeing type specimens of $L$. rufus, we still treat $L$. hirtus separately.

\section{Lasianthus hispidulus (Drake) Pit. — Map 6}

Lasianthus hispidulus (Drake) Pit. (1924) 393; H.Zhu (2001b) 130; (2002) 99. - Mephitidia hispidulus Drake (1895) 239. — Lectotype (selected by Zhu 2001b): Eberhardt 3852 (lecto P), Vietnam. Thai-nguyen.

Lasianthus brevidens Craib (1933) 19; (1934) 208; H.Zhu (1998) 151. - Type: Kerr 10833 (holo K; iso BM), Thailand, Rachaburi, Prachuap, 700 m.

Lasianthus bunzanensis Shimizu (1944) 301; T.S.Liu \& J.M.Chao (1964) 121 f. 3; H.Zhu (1994) 73; H.J.Li \& H.Y.Liu (1998) 277, pl. 122; H.S.Lo (1999) 99. - Type: Suzuki 16385 (holo TIU, n.v.), Taiwan, Taipei.

Shrubs, 1-1.5 m high; branchlets terete, c. $2 \mathrm{~mm}$ diam, densely brown-villous. Leaves: blades elliptic to ovate-oblong, 7-10 by $3-5 \mathrm{~cm}$, thinly coriaceous to chartaceous, apex cuspidateacuminate or acuminate, base acute or obtuse, glabrous above, densely villous beneath, midrib and nerves flat above, prominent beneath, nerves $4-6$ pairs, ascending at an angle of $60-70^{\circ}$, curved to the margin, nervules slightly obscure above, distinct beneath, subparallel; petioles 4-7 mm long, villous. Stipules minute, subulate, c. $1 \mathrm{~mm}$ long, hirsute. Cymes sessile; bracts absent. Flowers sessile, clusters; calyx campanulate, $1.5 \mathrm{~mm}$ long, densely villous, teeth 5 , minute, broad-triangular, c. 0.5 $\mathrm{mm}$ long, densely villous outside, glabrous inside; corolla white, 5-6 mm long, 5-lobed, pilose outside, villous inside. Drupes globose, hirsute, 3-5 mm diam; pyrenes 5 .

Distribution - China, Japan (Ryukyu), Vietnam, Thailand, Malaysia (Borneo), Indonesia (Sumatra, Java, Irian Jaya) and Papua New Guinea.

Note - Lasianthus brevidens from Thailand agrees well with L. hispidulus from Indochina, China (Hainan and Yunnan). We have not seen the type of $L$. bunzanensis from Taiwan, but from the original description and the checked specimens from Taiwan it is clear that $L$. bunzanensis is conspecific to $L$. hispidulus. This species is very closely related to $L$. clementis from the Philippines. It is separated from $L$. clementis only by having densely spreading hairs on branchlets, leaf undersurface, calyx and drupes, while L. clementis has densely more or less appressed hairs on branchlets, leaves beneath, and calyx, drupes appressed-pubescent or subglabrous. Both L. hispidulus and $L$. clementis have close affinity to $L$. fordii. They differ from $L$. fordii only by being densely hairy on branches, leaves beneath, and calyx.

\section{Lasianthus inodorus Blume}

\section{Key to the subspecies}

1. Branchlets and leaves glabrous or sparsely puberulous hairs on leaf lower surface; leaves relatively large, longer than 12

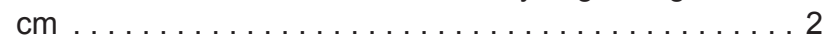

1. Branchlets and leaf lower surfaces appressed-pubescent; leaves relatively small, usually less than $12 \mathrm{~cm}$ long ....

c. subsp. pubescens

2. Branchlets with conspicuous lenticel; leaves oblong with subrounded bases; nerves 7-11 pairs; nervules subreticulate; bracts caducous. . . . . . . . . b. subsp. montigenus

2. Branchlets without conspicuous lenticel; leaves elliptic to elliptic-lanceolate with acuminate bases; nerves 6-7 pairs; nervules parallel; bracts persistent ... a. subsp. inodorus

\section{a. subsp. inodorus - Map 8}

Lasianthus inodorus Blume (1826-1827) 998; Miq. (1857) 322; (1869) 248; Merr. (1921) 577; Bakh.f. (1965) 339; H.Zhu (1998) 152; (2001a) 451; (2001b) 132; (2002) 77. - Mephitidia inodora (Blume) DC. (1830) 453. - Type: Blume s.n (holo L, barcode L0000690), Java. 
Lasianthus tubiferus Hook.f. (1880) 183; Craib (1934) 219; Deb \& M.Gangop. (1991) 305, f. 14; H.Zhu (1994) 59. - Type: Hooker \& Thomson s.n. (lecto K; designated by Deb \& Gangopadhyay 1991; isolecto A, L), India, Khasia. Lasianthus poilanei Pit. (1924) 398. - Type: Poilane 234 (holo P; iso E, K), Mt Elephant, 1000 m, Cambodia.

Shrubs, 2-3 m high; branches and branchlets glabrous or thinly puberulous. Leaves: blades elliptic to elliptic-lanceolate, 10-20 by $2.5-6 \mathrm{~cm}$, coriaceous, glabrous above, glabrous or sparsely puberulous beneath, apex acuminate, base acuminate; nerves 6-7 pairs, nervules parallel, nerves and nervules conspicuous beneath; petioles $6-10 \mathrm{~mm}$ long, glabrous or sparsely puberulous. Stipules triangular or ovate-lanceolate, 3-5 mm long, glabrous, coriaceous. Cymes sessile; bracts persistent, 3-6 mm long, orbicular or ovate-orbicular, thickly coriaceous, glabrous or pubescent. Flowers sessile; calyx tubular, tube $2 \mathrm{~mm}$ long, glabrous, with 5 ovate-lanceolate lobes, puberulous outside; corolla $10 \mathrm{~mm}$ long, puberulous outside, villous inside. Drupes ovoid, $10 \mathrm{~mm}$ long, glabrous; pyrenes 5.

Distribution - India (northeast part), Bangladesh (eastern part), China (Yunnan), Vietnam, Cambodia, Thailand, Indonesia (Sumatra, Java).

Note - Subsp. inodorus has a wide, disjunct distribution. However, the specimens from mainland SE Asia and the ones from Sumatra and Java are almost identical so that clear variation within this subspecies cannot be recognized.

\section{b. subsp. montigenus H.Zhu - Map 8}

Lasianthus inodorus Blume subsp. montigenus H.Zhu (2001a) 451. - Type: Zhu 98-7-01 (holo HITBC), Borneo, Kinabalu, alt. 2400 m, in upper montane forest.

Shrubs, 2-3 m tall; branches subterete or slightly tetragonous, striate and conspicuously lenticellate, glabrous, incrassate at nodes, internode $3.5-4 \mathrm{~cm}$ long, nigrescent when drying. Leaves: blades $12-15$ by $3.5-5.5 \mathrm{~cm}$, oblong, apex shortly caudate, base subrounded, coriaceous, glabrous on both sides, nerves 7-11-paired, tertiary nerves subreticulate, nerves and tertiary nerves conspicuous on both sides; petioles $5 \mathrm{~mm}$ long, glabrous. Stipules ovate-triangular, 3-5 mm long, apex acuminate, pubescent. Inflorescences sessile; bracts orbicular, subcoriaceous, caducous. Flowers sessile; calyx glabrescent, tube $2.5 \mathrm{~mm}$ long, lobes 5, broad-triangular, $2 \mathrm{~mm}$ long, apex and margin pubescent. Fruits oblong, $10 \mathrm{~mm}$ long, glabrous; pyrenes 5 .

Distribution - Endemic to Borneo.
Additional specimens examined. Borneo, Kinabalu, alt. $7000 \mathrm{ft}$, Clemens $32536(\mathrm{~K})$

\section{c. subsp. pubescens H.Zhu - Map 8}

Lasianthus inodorus Blume subsp. pubescens H.Zhu (2001a) 451. - Type: Zhu 98-7-02 (holo HITBC), Borneo, Kinabalu, alt. 1600 m, in lower montane forest.

Shrubs, 1-1.5 m tall; branches subterete, densely appressedpubescent, incrassate at nodes, internode $2.5-3 \mathrm{~cm}$ long. Leaves: blades $6-13$ by $2.2-5 \mathrm{~cm}$, oblong-lanceolate, apex subacute to shortly acuminate, base broadly cuneate, coriaceous, glabrous above, pubescent beneath, nerves 6-7-paired, tertiary nerves subparallel, nerves and tertiary nerves conspicuous on both sides; petioles $3 \mathrm{~mm}$ long, pubescent. Stipules triangular, $5 \mathrm{~mm}$ long, apex acuminate, densely pubescent. Inflorescences sessile; bracts orbicular, subcoriaceous, pubescent, semi-persistent. Flowers sessile; calyx tube $2 \mathrm{~mm}$ long, pubescent outside, lobes 5, $2 \mathrm{~mm}$ long, broad-triangular, pubescent outside, apex and margin densely pubescent; corolla $8 \mathrm{~mm}$ long, tube $4-5 \mathrm{~mm}$ long, glabrescent outside, lobes subspathulate, pubescent outside, villous inside; stamens 5 ; anthers oblong. Mature fruit not seen.

Distribution - Endemic to Borneo (Sabah, Brunei, Sarawak, Kalimantan).

Notes - Subsp. pubescens has coriaceous elliptic or ellipticlanceolate leaves and conspicuously orbicular or ovate coriaceous bracts that make it a clear species in the genus.

Lasianthus inodorus from the mountains of Sumatra and Java is clearly conspecific to $L$. poilanei of Cambodia and $L$. tubiferus from India, Thailand and Yunnan of China. The species has coriaceous elliptic or elliptic-lanceolate leaves and persistent orbicular coriaceous bracts, which clearly distinguish it in the genus.

\section{Lasianthus iteoides Valeton ex H.Zhu, sp. nov. - Fig. 18}

Similis $L$. hexandro Blume, sed lobis calycis triangulatis c. $1 \mathrm{~mm}$ longis aequalis tubo differt. - Typus: Bünnemeijer 3578 (holo L), Indonesia, Sumatra Barat, Malintang, Gunung, c. 1100 m alt., 18 July 1918

Shrub, c. $3 \mathrm{~m}$ high; branchlets terete, c. $1.5 \mathrm{~mm}$ diam, densely appressed hirsute. Leaves: blades lanceolate to oblong lanceolate, $6-13$ by $1.6-3 \mathrm{~cm}$, subcoriaceous, glabrous above except hirsute midrib, villose beneath; apex acute to acuminate, margin slightly recurved, base acute, midrib depressed above,

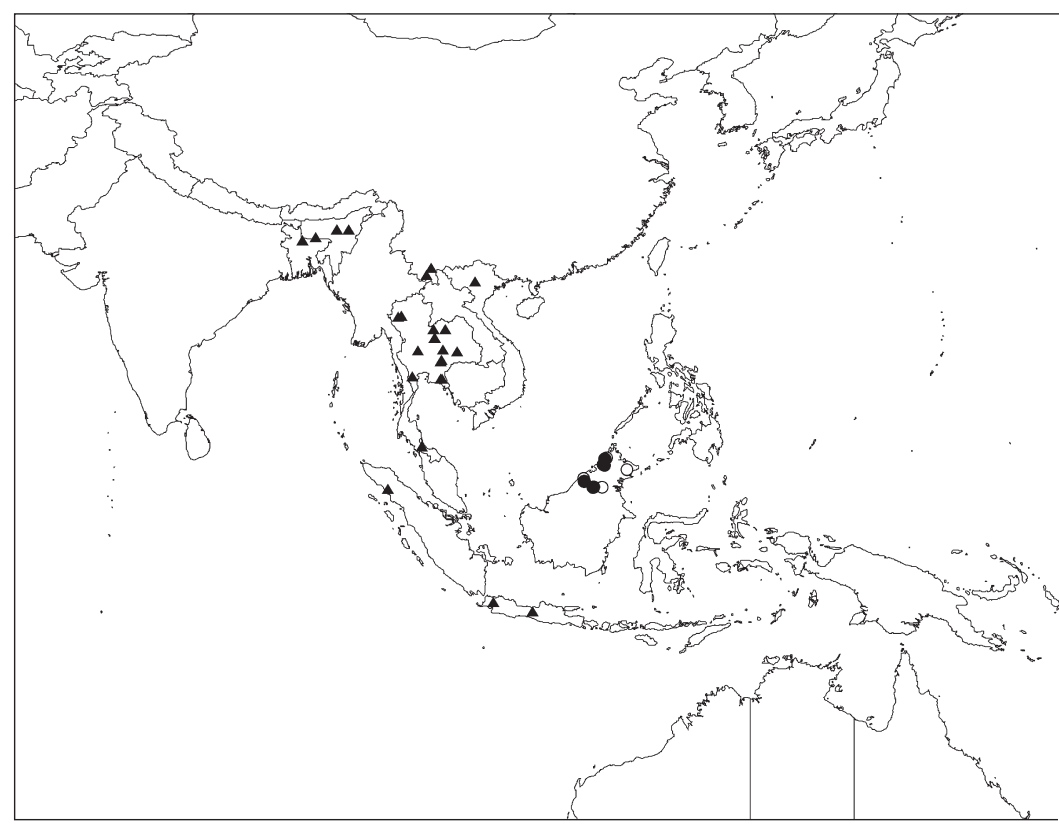

8 Distribution of Lasianthus inodorus Blume (A), inodorus subsp. montigenus H.Zhu (O) and L. inodorus subsp. pubescens $\mathrm{H}$.Zhu $(\mathrm{O})$. 


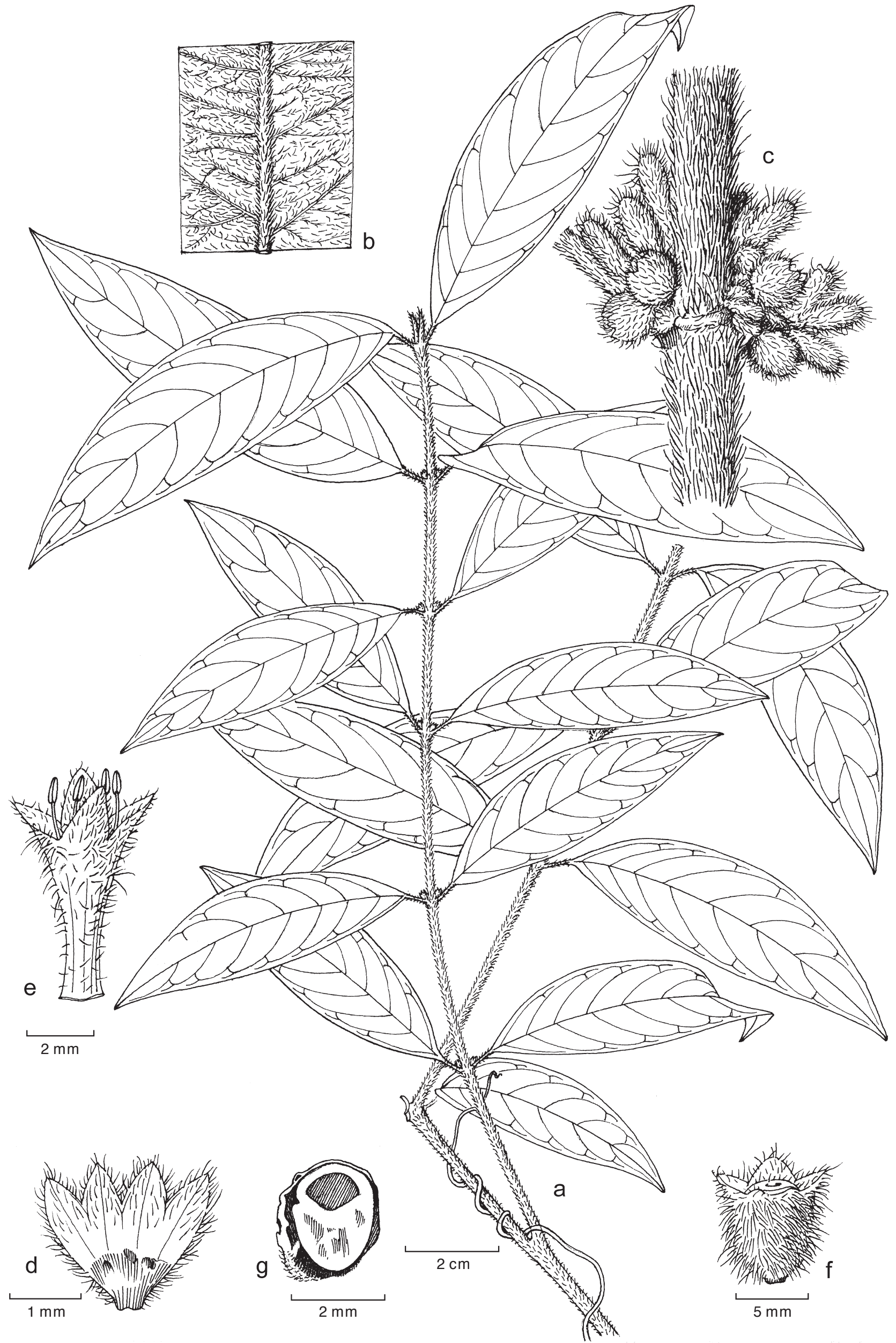

Fig. 18 Lasianthus iteoides Valeton ex H.Zhu. a. Habit; b. detail of lower surface of leaf showing indumentum; c. detail of node showing axillary inflorescences; d. calyx split opened; e. corolla; f. fruit; g. cross section of pyrene (all: Bünnemeijer 3578, holo L). 
prominent beneath, hirsute, nerves depressed and obscure above, prominent and conspicuous beneath, hirsute beneath, $7-8$ pairs, ascending at an angle of $60-70^{\circ}$, curved to margin, nervules obscure above, conspicuous beneath, villose, reticulate; petioles c. $5 \mathrm{~mm}$ long, densely appressed hirsute. Stipules triangular, $1 \mathrm{~mm}$ long, appressed hirsute. Inflorescences sessile; bracts inconspicuous. Flowers fascicular, sessile; calyx obconical, c. $2 \mathrm{~mm}$ long, densely villose, lobes 4-5, triangular, $1 \mathrm{~mm}$ long, villose both surfaces; corolla claviform when in bud, densely spreading villose, $6-7 \mathrm{~mm}$ long, lobes triangular-oblong, c. $2 \mathrm{~mm}$ long; stamens with c. $0.8 \mathrm{~mm}$ long filaments; styles $5 \mathrm{~mm}$ long. Drupes globose, c. $5 \mathrm{~mm}$ diam, villose; pyrenes 5 , smooth on the abaxial face.

Distribution - W Sumatra.

Habitat \& Ecology — In forest between 100-1100 m altitude. Flowering in July; fruiting in September.

Additional specimens examined. Sumatra, Malintang, Bünnemeijer 3862 (L); Sumatra, Sago, Gunung, Bünnemeijer 3686 (L), Dayar Arbain DA399 (L).

Notes - This species is similar to $L$. hexandrus, but differs from the latter by having triangular calyx lobes, c. $1 \mathrm{~mm}$ long, as long as the calyx tube. Lasianthus hexandrus has lanceolate calyx lobes, 3-4 mm long, conspicuously longer than the tube.

Valeton recognized the species as a new one, but did not made the description except a determination label on the type specimen. Here we described it as a new species.

\section{Lasianthus iteophyllus Miq.}

Lasianthus iteophyllus Miq. (1869) 247; Bakh.f. (1965) 340. - Lectotype (designated here): Blume s.n. (lecto L, barcode L0305214). Paratypes: Blume s.n. (L, barcode L0305211), Blume s.n. (L, barcode L0305213), Java.

Shrubs; branchlets terete, c. $2 \mathrm{~mm}$ diam, sparsely hirsute, darkbrown in the youngest part. Leaves: blades lanceolate, 12-14 by $2.5-3 \mathrm{~cm}$, thinly coriaceous, glabrous on both surfaces except sparsely hirsute hairs on midrib and nerves beneath, apex caudate-acuminate, base acute, slightly asymmetric, midrib and nerves slightly prominent above, prominent beneath, nerves $10-11$ pairs, ascending at an angle of $60-70^{\circ}$, curved to the margin, nervules distinct and prominent on both surfaces, reticulate; petioles 3-4 mm long, hirsute. Stipules triangular, 3-4 $\mathrm{mm}$ long, glabrous except long-pilose hairs on the margin, coriaceous. Cymes sessile; bracts absent. Flowers sessile; calyx campanulate, $2-2.5 \mathrm{~mm}$ long, glabrous, limb pilose inside, with 5-6 minute teeth, teeth subulate, c. $0.5 \mathrm{~mm}$ long, pilose at the margin and inside; corolla not seen. Drupes globose, glabrous, very verrucose; pyrenes 5-6, irregular sulcate on the abaxial face.

Distribution — Indonesia (Java).

\section{Lasianthus kinabaluensis Stapf}

Lasianthus kinabaluensis Stapf (1894) 184; Wernham ex Gibbs (1914) 95; Merr. (1921) 577. - Type: Haviland 1306 (lecto K; designated here; isolecto SING); Haviland 1323 (para K), Borneo, Penokok, 3000-3200 ft.

Shrubs, up to $2 \mathrm{~m}$ high, glabrous; branchlets terete, slender, c. 1 $\mathrm{mm}$ diam, nitid. Leaves: blades lanceolate, $5-10$ by $1.5-2.5$ $\mathrm{cm}$, thinly coriaceous, apex caudate-acuminate, base acute or cuneate, the margin often reflexed, midrib flat or depressed above, prominent beneath, nerves slender, prominent beneath, 3-4 pairs, ascending at an angle of over $60^{\circ}$, curved near the leaf margin and joining the veins above forming an intramarginal vein, nervules slender, loosely anastomosing, distinct beneath, reticulate; petioles 5-10 $\mathrm{mm}$ long. Stipules minute, triangular, c. $1 \mathrm{~mm}$ long, ciliate at margin. Cymes sessile; bracts absent. Flowers sessile; calyx campanulate, c. $1.5 \mathrm{~mm}$ long, glabrous, lobes 4-5, triangular, c. $0.8 \mathrm{~mm}$ long; corolla c. $4-5 \mathrm{~mm}$ long, glabrous outside, lobes 4-5. Drupes subglobose, c. $5 \mathrm{~mm}$ diam, glabrous, 3-4-obtuse-ridged, verrucose; pyrenes 3-4, verrucose on the abaxial face.

Distribution - Endemic to Borneo.

Note - This species is related to $L$. constrictus by its glabrous plants, calyx constricted at the base of the limb and warty drupes with 3-4 pyrenes. It differs from the latter by having relatively small and thin leaves with looped venation.

\section{Lasianthus laevigatus Blume}

Lasianthus laevigatus Blume (1826-1827) 998; Miq. (1857) 320; (1869) 247; Boerl. (1891) 140; Merr. (1921) 577; Bakh.f. (1965) 337. - Lectotype (designated here): Blume s.n. (lecto L, barcode L0000692). Paratypes: Blume s.n. (L, barcode L0000691), Blume s.n. (L, barcode L0000693), Blume s.n. (L, barcode L0000694), Java, Salak.

Shrubs, up to $5 \mathrm{~m}$ high, glabrous; branchlets terete, $2-3 \mathrm{~mm}$ diam, dark-brown when dry. Leaves: blades oblong-lanceolate, $9-18$ by $2-4.5 \mathrm{~cm}$, coriaceous, apex cuspidate-acuminate, margin often reflexed and more or less undulate, base acuminate, midrib and nerves prominent on both surfaces, nerves 8-10 pairs, slender, ascending at an angle of over $60^{\circ}$, curved to the margin, nervules obscure above, distinct beneath, reticulate; petioles $1-2 \mathrm{~cm}$ long. Stipules triangular, c. $3 \mathrm{~mm}$ long, glabrous. Cymes pedunculate, glabrous; main peduncles 1-1.5 cm long; branches 5-8 mm long; bracts subulate, 1-2 $\mathrm{mm}$ long, minutely ciliate. Flowers sessile; calyx tube tubularcampanulate, c. $5 \mathrm{~mm}$ long, glabrous, calyx lobes 4 , lanceolate, 5-6 mm long, glabrous; corolla 7-8 mm long, tube glabrous, lobes 6 , glabrous outside, densely floccose inside; stamens 6 . Drupes turbinate, c. 5-6 mm diam, glabrous, conspicuously 6-ridged; pyrenes 6.

Distribution - Endemic to Indonesia (Java).

Habitat \& Ecology - From lowland rainforests to montane forests between 700-1400 m altitude. Flowering in March; fruiting in April.

\section{Lasianthus lancilobus H.Zhu, sp. nov. - Fig. 19}

Proximus L. robinsonii Ridl., sed ramulis costis nervis subtus, pedunculis et calycibus sparsim hirsutis, nervis 5-6-binatis, nervulis subparallelis, petiolis $6-8 \mathrm{~mm}$ longis, bracteis late-linearis costatis $1.5 \mathrm{~mm}$ longis et lobis calycis lanceolatis nervatis differt. - Typus: Church et al. 2639 (holo L; iso K), Borneo, W Kalimantan, Serawai, 1600 m alt., in upper montane mossy forest, 22 Oct. 1995.

Treelet, $2 \mathrm{~m}$ high; branchlets terete, c. $1.5 \mathrm{~mm}$ diam, deeply brown, sparsely hirsute. Leaves: blades oblong, $6-13$ by $2.5-$ $3.5 \mathrm{~cm}$, chartaceous, glabrous except sparsely hirsute midrib and nerves beneath, apex acuminate to shortly caudate, base acute, midrib slightly depressed above, prominent beneath, nerves flat above, prominent beneath, 5-6 pairs, nervules obscure above, conspicuous beneath, subparallel; petioles 6-8 $\mathrm{mm}$ long, hirsute. Stipules lanceolate, c. $3 \mathrm{~mm}$ long, hirsute. Inflorescences peduncled; peduncles slender, c. $0.3 \mathrm{~mm}$ diam, $2.5-3 \mathrm{~cm}$ long, hirsute; bracts 2 at each node, usually unequal, longer ones linear and with a midrib, up to $1.5 \mathrm{~cm}$ long, $1 \mathrm{~mm}$ broad, sparsely hirsute; shorter ones narrowly linear, hirsute. Flowers pediceled; pedicels 1-3 mm long, hirsute; calyx hirsute, lobes 4 , lanceolate, usually nerved, $5 \mathrm{~mm}$ long, hirsute external surface, tube c. $2 \mathrm{~mm}$ long; corolla not seen. Drupes subglobose, glabrous, 4 obtuse ridges, verrucose on surface, 4-5 mm diam, crowned by lanceolate calyx lobes.

Distribution - Indonesia (W Kalimantan).

Habitat \& Ecology — In upper montane mossy forest. Flowering in October.

Note - This species is characterized by its slender peduncles, linear bracts with a midrib and nerved lanceolate calyx 


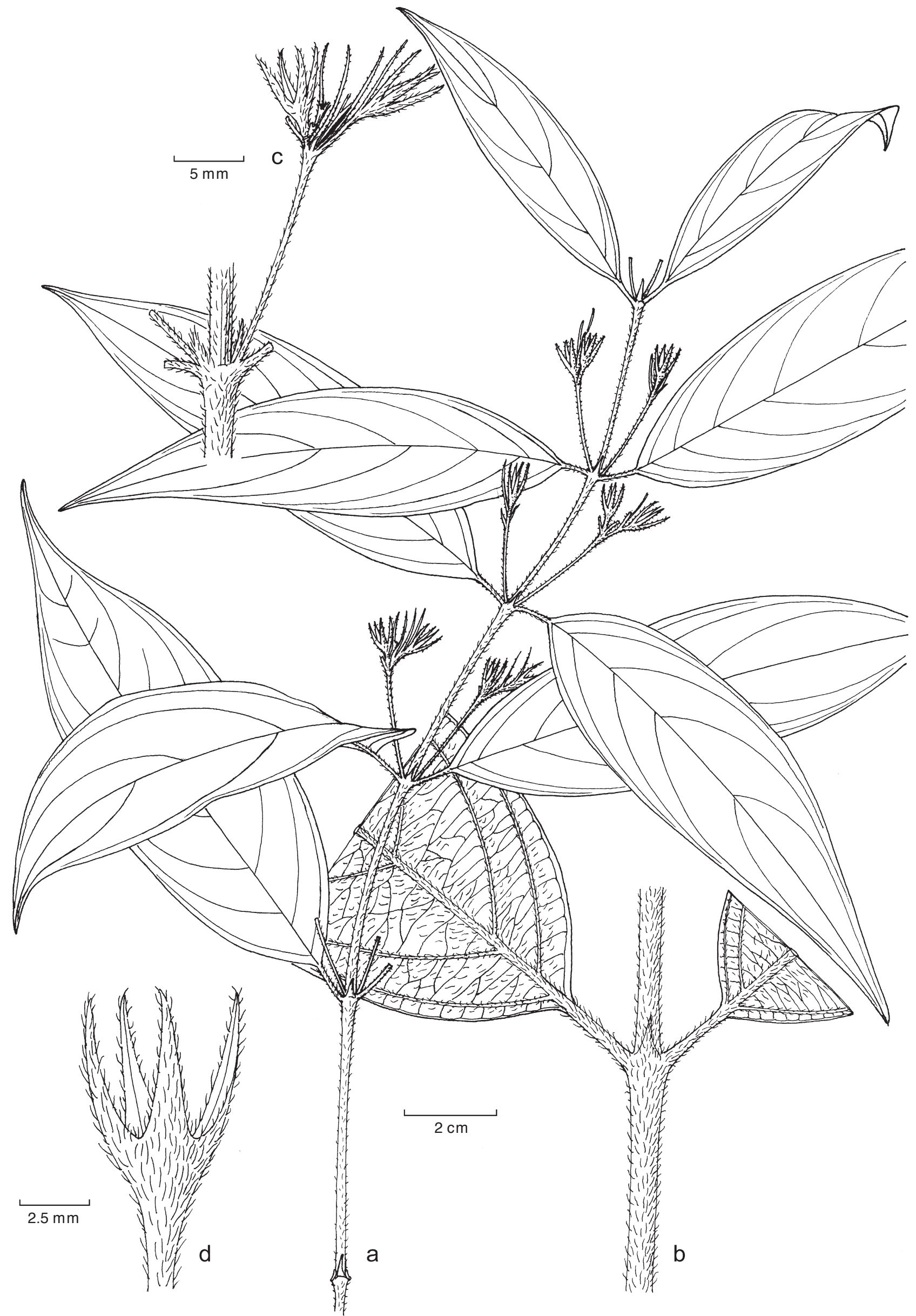

Fig. 19 Lasianthus lancilobus H.Zhu. a. Habit with inflorescences; b. detail of branch; c. detail of inflorescence; d. calyx (all: A.C. Church et al. 2639, holo L). 
lobes. It is closely related to $L$. robinsonii, but differs from the latter by having sparsely hirsute branches and leaf midrib and nerves beneath, peduncles and calyx; nerves 5-6 pairs, nervules subparallel; petioles 6-8 $\mathrm{mm}$ long; bracts broadly linear with a midrib, up to $1.5 \mathrm{~cm}$ long; calyx lobes lanceolate, nerved. Lasianthus robinsonii has spreading tomentose branches, leaf nerves beneath and peduncles; nerves 8 pairs, nervules reticulate; petioles short, less than $3 \mathrm{~mm}$ long; bracts subulate-linear, less than $1 \mathrm{~cm}$ long and without a midrib; calyx lobes subulate.

\section{Lasianthus latifolius (Blume ex DC.) Miq.}

Lasianthus latifolius (Blume ex DC.) Miq. (1857) 320; (1869) 245; Merr. (1921) 577; Bakh.f. (1965) 342. - Mephitidia latifolia Blume ex DC. (1830) 453. - Type: Blume s.n. (lecto L, designated here, barcode L0057522). Paratypes: Blume s.n. (L, barcode L0057523), Blume s.n. (L, barcode L0057524), Blume s.n. (L, barcode L0057525), Blume s.n. (L, barcode L0057526), Java, Salak.

Shrubs; branchlets terete, robust, c. $3 \mathrm{~mm}$ diam, glabrous except appressed-puberulous nodes. Leaves: blades ellipticoblong, $13-15$ by $5-7 \mathrm{~cm}$, coriaceous, glabrous except sparsely hirsute hairs on midrib and nerves beneath, apex cuspidate, base acute or broadly cuneate, midrib slightly depressed above, prominent beneath, nerves slightly prominent above, prominent beneath, c. 7 pairs, ascending at an angle of $60-70^{\circ}$, curved to the margin, nervules prominent on both surfaces, densely anastomosing, parallel; petioles $1-1.5 \mathrm{~cm}$ long, appressed-puberulous. Stipules triangular, c. $3 \mathrm{~mm}$ long, appressed-puberulous. Cymes sessile or very small tuberculate (c. $1 \mathrm{~mm}$ long); bracts absent. Flowers sessile; calyx campanulate, puberulous, tube c. $1.5 \mathrm{~mm}$ long, lobes 5 , lanceolate-triangular, c. $2.5 \mathrm{~mm}$ long; corolla not seen. Drupes globose, red in colour, c. $5 \mathrm{~mm}$ diam, glabrous, 12-ridged; pyrenes 6 , sulcate on the abaxial face.

Distribution - Indonesia (Java).

Note - This species is closely related to $L$. calycinus Dunn from Hainan of China.

\section{Lasianthus laxifloroideus H.Zhu, sp. nov. - Fig. 20}

Proximus $L$. laxifloro Merr. sed ramulis costia nervis subtus stipulis pedunculis calycis appressi-pubescentibus, foliis angustioribus, petiolis $5 \mathrm{~mm}$ longis, stipulis minoribus triangularis $2 \mathrm{~mm}$ longis, cymis $1-2 \mathrm{~cm}$ longis differt. A L. dinghoui $\mathrm{H}$.Zhu foliis oblongis vel ovato-oblongis $2.5-4.5 \mathrm{~cm}$ latis apice acuminatis vel cuspidatis, lobis calycis lanceolatis $1.5 \mathrm{~mm}$ longis differt. Typus: Ching S. 40794 (holo L; iso K, L), Borneo, Sabah, Kelingkang Range, $1650 \mathrm{ft}$, in mixed dipterocarp forest, 10 Oct. 1979

Shrub, up to $3 \mathrm{~m}$ high; branchlets terete, c. $1.5 \mathrm{~mm}$ diam, densely appressed-pubescent. Leaves: blades oblong or ovateoblong, $10-16$ by $2.5-4.5 \mathrm{~cm}$, subcoriaceous, glabrous except appressed-pubescent midrib and nerves beneath, apex acuminate to cuspidate, base abruptly acute to subrounded, midrib and nerves slightly prominent above, conspicuously prominent beneath, nerves 3-6 pairs, nervules prominent on both surfaces, more conspicuous beneath, parallel; petioles c. $5 \mathrm{~mm}$ long, appressed-pubescent. Stipules triangular, c. 2 $\mathrm{mm}$ long, appressed-pubescent. Inflorescences peduncled, appressed-pubescent; peduncles $0.5-2 \mathrm{~cm}$ long, trifurcate at each node; bracts subulate-linear, 2-3 mm long, pubescent; bracteoles small, subulate, c. $1 \mathrm{~mm}$ long. Flowers pediceled; pedicels 3-5 mm long, articulate, appressed-pubescent; calyx campanulate, appressed-puberulous, tube $1.5 \mathrm{~mm}$ long, lobes 4, oblong-lanceolate, c. $1.5 \mathrm{~mm}$ long; corolla glabrous external surface, 6-7 mm long, lobes 4. Drupes rhomboidal-globose, $5 \mathrm{~mm}$ diam, glabrous, verrucose external surface, conspicuously 4-ridged; pyrenes 4 , strongly verrucose on abaxial face and sides.

Distribution - Malaysia (Borneo).
Habitat \& Ecology — In lower montane forests between 350$900 \mathrm{~m}$ altitude. Flowering in April; fruiting in October.

Additional specimens examined. W Kalimantan, Serawai, A.C. Church et al. 2001 (L); W Kalimantan, Kabupaten Sanggau, W. de Jong 889 (L); Sarawak, Lubok Antu, Dyg Awa et al. 44116 (L); Sabah, Kelingkang Range, Rena et al. S. 58966 (L); Sabah, Serian, B. \& K. Bremer 1650 (L); Sarawak, G. Lesong, B. Lee S.43203 (L).

Note - This species is closely related $L$. laxiflorus and $L$. dinghoui H.Zhu. It differs from $L$. laxiflorus by having appressed-pubescent branches, leaf midrib and nerves beneath, stipules, peduncles, and calyx; petioles $5 \mathrm{~mm}$ long; stipules small, triangular, c. $2 \mathrm{~mm}$ long; inflorescence 1-2 cm long. While $L$. laxiflorus is a glabrous plant and has petioles $6-10 \mathrm{~mm}$ long, stipules lanceolate 5-7 mm long, inflorescence $3-4 \mathrm{~cm}$ long. It differs from $L$. dinghoui by having densely appressedpubescent on branches, and leave beneath, leaves oblong to ovate-oblong, more than $2.5 \mathrm{~cm}$ broad; leaf apex acuminate to cuspidate; calyx lobes oblong-lanceolate, c. $1.5 \mathrm{~mm}$ long.

\section{Lasianthus laxiflorus Merr.}

Lasianthus laxiflorus Merr. (1937) 298. - Type: Winkler 430 (holo HBG; iso HBG, NY), W Borneo, Bukit Mulu, 450 m alt.

Shrubs to treelets, $3 \mathrm{~m}$ high, glabrous; branchlets terete, c. 2.5 $\mathrm{mm}$ diam, slightly compressed in the youngest part. Leaves: blades oblong, $10-19$ by $2.5-6 \mathrm{~cm}$, coriaceous, apex cuspidate, base acute to broadly cuneate, midrib and nerves slightly depressed above, prominent beneath, nerves $3-5$, ascending at an angle of $50-60^{\circ}$, curved to the margin, nervules distinct on both surfaces, subreticulate; petioles 6-12 mm long. Stipules triangular to triangular-lanceolate, up to $5 \mathrm{~mm}$ long, glabrous. Cymes pedunculate; main peduncles up to $3 \mathrm{~cm}$ long, slender, trifurcate; branches 5-10 mm long; bracts subulate-linear, 2-3 $\mathrm{mm}$ long. Flowers subsessile, articulate; calyx obconical, with 4-5 teeth, tube c. $2 \mathrm{~mm}$ long, teeth subulate, c. $1 \mathrm{~mm}$ long; corolla c. $8 \mathrm{~mm}$ long, subglabrous, lobes $4-5$, oblong-ovate; anthers 4-5, oblong; ovary 4-locular. Drupes ellipsoid, c. $4 \mathrm{~mm}$ diam verrucose; pyrenes 3-4.

Distribution - Endemic to Borneo (Sarawak, Sabah, Kalimantan).

Note - This species is strongly characterized by being glabrous, having relatively large subcoriaceous oblong leaves (13-19 by $5-6 \mathrm{~cm}$ ) with acute or cuspidate apex and broadly acute base, midrib and nerves conspicuously prominent beneath, stipules subulate-lanceolate up to $5 \mathrm{~mm}$ long, cymes peduncled, usually two peduncles in each axil, main peduncles up to $3 \mathrm{~cm}$ long, bracts subulate-linear, $3 \mathrm{~mm}$ long.

\section{Lasianthus ledermannii Valeton}

Lasianthus ledermannii Valeton (1927) 108. - Type: Ledermann 9373b (B十), New Guinea, Etappenberg, 850 m; Takeuchi 5096 (neo L, designated here; isoneo K), New Guinea, East Sepik, Hunstein range, $915 \mathrm{~m}$ alt., 29 Sept. 1989.

Shrubs or treelets, $1.5 \mathrm{~m}$ high; branchlets terete, robust, c. $3 \mathrm{~mm}$ diam, densely dark-brown-tomentose. Leaves: blades elliptic, elliptic-oblong, $8-13$ by $3-5 \mathrm{~cm}$, coriaceous, glabrous above except hirsute hairs on midrib, densely brown-tomentose beneath, apex cuspidate or shortly caudate, margin slightly reflexed, base cuneate to subrounded, rarely asymmetric, midrib and nerves flat to slightly depressed above, prominent beneath, nerves $6-9$ pairs, ascending at an angle of $45-60^{\circ}$, curved to the margin, nervules obscure above, distinct and prominent beneath, subparallel; petioles c. $5 \mathrm{~mm}$ long, densely tomentose. Stipules triangular-lanceolate, c. $5 \mathrm{~mm}$ long, densely tomentose. Cymes sessile; bracts numerous, lanceolate to linear-lanceolate, 5-8 mm long, densely tomentose. Flowers 


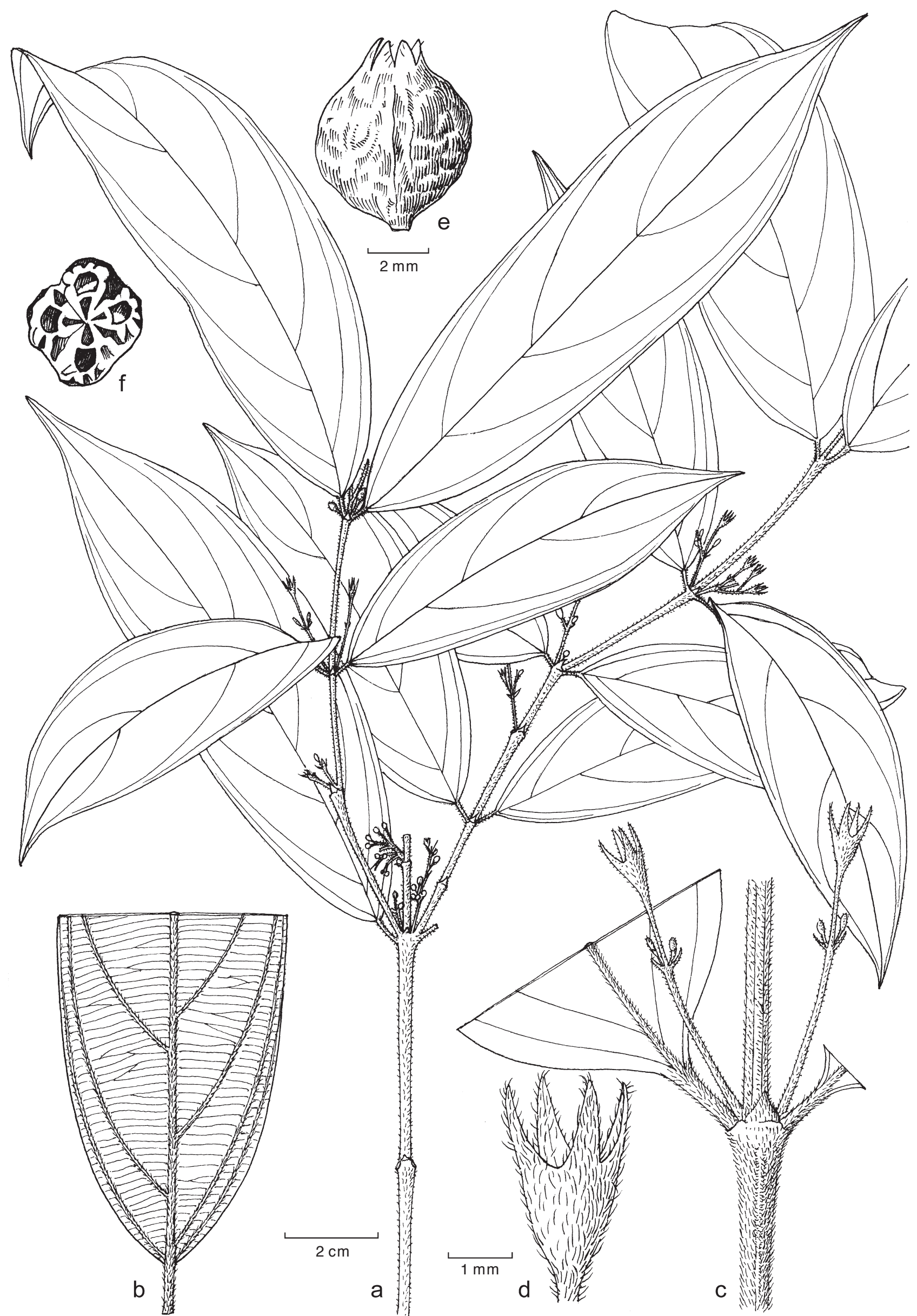

Fig. 20 Lasianthus laxifloroideus H.Zhu. a. Habit with inflorescences; b. detail of lower surface of leaf showing parallel nervules; c. detail of node showing stipule and axillary inflorescences; d. calyx; e. fruit; f. cross section of fruit (all: Y.P. Ching S.40794, holo and iso L). 
sessile; calyx obconical, densely tomentose, tube c. $1 \mathrm{~mm}$ long, lobes 5, lanceolate, c. $1.5 \mathrm{~mm}$ long; corolla tube 4-5 mm long, glabrous, lobes 5, ovate, c. $3 \mathrm{~mm}$ long, hairy both sides. Drupes globose to subglobose, $4-5 \mathrm{~mm}$ diam, tomentose; pyrenes 5 , smooth on the abaxial face.

Distribution — Indonesia (Irian Jaya) and Papua New Guinea.

Notes - According to Valeton, this species has fuliginoustomentose hairs on branches, leaves nerves beneath, bracts, and drupes; leaves short petiolate, elliptic-oblong or ellipticlanceolate, subcoriaceous; midrib above and nerves beneath tomentose; nerves 6-7; stipules linear, hirsute; bracts numerous, subulate-linear, outer ones 7-10 mm long; calyx hirsute, lobes $2 \mathrm{~mm}$ long; drupes globose, apex hirsute.

The type of $L$. ledermannii was destroyed during World War II in Berlin. There are several specimens from New Guinea, which agree well with the description of $L$. ledermannii. Among them, Takeuchi 5096 perfectly matches the type description. Therefore we select it as a neotype.

This species is closely related to the western Malaysian species L. ellipticus.

\section{Lasianthus linearifolius H.Zhu, sp. nov.}

Similis $L$. angustifolius King \& Gamble, sed ramulis et foliis glabris, foliis linearibus, lobis calycis triangularibus 4 differt. - Typus: Beaman et al. 7783 (holo L), Borneo, Sabah, Ranau, $750 \mathrm{~m}$ alt., in dipterocarp forest, on ultramafic soil, 8 Dec. 1983.

Shrub, $1 \mathrm{~m}$ high; branchlets terete, slender, less than $1 \mathrm{~mm}$ diam, sparsely puberulous or glabrous. Leaves: blades linear, $10-14$ by $0.9-1.8 \mathrm{~cm}$, subcoriaceous, glabrous or except sparsely pubescent midrib beneath, apex long-caudate, margin slightly undulate, base acute, midrib slightly prominent above, conspicuously prominent beneath, nerves slender, slightly prominent above, prominent beneath, 10-16 pairs, ascending at an angle of $80-90^{\circ}$, curved near margin, going paralleling to margin for some distance and joining the nerves above, forming an obscure intramarginal vein, nervules obscure above, weakly prominent beneath, subparallel; petioles $3-6 \mathrm{~mm}$ long, sparsely puberulous. Stipules small, subulate, c. $1 \mathrm{~mm}$ long, pubescent. Inflorescences sessile; bracts absent. Flowers fascicular, sessile; immature calyx campanulate, pubescent or glabrous, tube c. $1 \mathrm{~mm}$ long, lobes 4 , triangular, up to $1 \mathrm{~mm}$ long; corolla pubescent on external surface. Drupes subglobose, with 4 obtuse ridges, c. $3 \mathrm{~mm}$ diam, puberulous or glabrous, crowned by 4 small triangular calyx lobes; pyrenes 4 .

Distribution - Malaysia (Sabah).

Habitat \& Ecology - In dipterocarp forest of SE base of Mt Kinabalu on ultramafic soil. Flowering and fruiting in December.

Additional specimen examined. Sahab: Ranau, D. Andau 1049 (K).

Note - This species is characterized by its linear leaves. It differs from $L$. angustifolius by having almost glabrous branchlets and leaves, leaves linear, calyx with 4 triangular lobes. Lasianthus angustifolius has branchlets densely pubescent, leaves oblong-lanceolate, leaf midrib and nerves densely pubescent, calyx with 5 triangular teeth.

\section{Lasianthus longibracteatus H.Zhu, sp. nov. - Fig. 21}

Proximus $L$. rhinocerotis Blume, sed foliis majoribus $26-40 \mathrm{~cm}$ longis subtus hispidis, nervulis reticulatis, bracteis conspicue lonioribus, calycibus fissilobis, lobis calycis lineario-lanceolatis 5-6 mm longis differt. A L. megaphyllo H.Zhu foliis subtus hispidis basi subrotundatis, petiolis longioribus, cymis capitatis brevi-pedunculatis, bracteis numerosis $3 \mathrm{~cm}$ longis differt. - Typus: Burley et al. 858 (holo L), Kalimantan, S. Kahayan, $150 \mathrm{~m}$ alt., in primary lowland forest, 1 May 1988.
Shrub, 1-1.5 $\mathrm{m}$ high; branchlets robust, 6-7 mm diam, fistulose, compressed, glabrescent. Leaves: blades obovate-oblong, coriaceous, $26-46$ by $10-12 \mathrm{~cm}$, glabrous above, hispid hairs on venation beneath, apex cuspidate to obtuse, base subrounded; midrib depressed above, conspicuously prominent beneath, hispid beneath, nerves depressed above, prominent beneath, 12-15 pairs, ascending at an angle of c. $60^{\circ}$, curved to the margin, hispid beneath, nervules depressed above, prominent beneath, reticulate; petioles c. $1 \mathrm{~cm}$ long, hirsute. Stipules triangular-lanceolate, c. $1 \mathrm{~cm}$ long, $4-5 \mathrm{~mm}$ broad at base. Inflorescences axillary, capitate, very short pedunculate or subsessile; peduncles 1-2 mm long; bracts numerous, linear, up to $3 \mathrm{~cm}$ long, densely hirsute. Flowers covered by bracts, sessile; calyx split into 5 linear-lanceolate lobes near to the base lobes 5-6 $\mathrm{mm}$ long, $1 \mathrm{~mm}$ broad, hirsute external surface and densely hirsute at apex, glabrous internal surface; corolla $12 \mathrm{~mm}$ long, subglabrous except the upper part; style filiform, up to $15 \mathrm{~mm}$ long; stigma 4-5, filiform. Drupes subglabrous, $6 \mathrm{~mm}$ diam, conspicuously 6-ridged, smooth; pyrenes 6, smooth on the abaxial face, ovate-triangular in transverse section.

Distribution - Endemic to Borneo (Sarawak, Kalimantan).

Habitat \& Ecology — In lowland dipterocarp forest. Flowering in May; fruiting in February.

Additional specimens examined. W Kalimantan, W. de Jong 760 (L), A.C. Church et al. 1681; Borneo, unknown coll., L barcode L0310812, L0310813; Borneo, H. Hallier 2016, Teysmann 8005; Sarawak, W.M.A. Brooke 9348.

Note - This species has the biggest leaves and the longest bracts in the genus. It is close to $L$. rhinocerotis by its similar capitate inflorescence with short peduncles and numerous linear bracts. It differs from the latter by having much larger leaf blades (26-40 cm long) covered with hispid hairs beneath, and with reticulate nervules; bracts up to $3 \mathrm{~cm}$ long; calyx split to the base; calyx lobes linear-lanceolate, 5-6 mm long. It differs from L. megaphyllus by having leaves with subrounded base, hispid beneath; leaf venation more prominent beneath; petioles $1 \mathrm{~cm}$ long; inflorescence capitate, very short pedunculate; bracts numerous, linear, up to $3 \mathrm{~cm}$ long, densely hirsute.

\section{Lasianthus longifolius Wight}

\section{Key to the subspecies and varieties}

1. Leaves with rigid, minute hairs on venation beneath; nervules conspicuously prominent beneath; corolla shorter, less than $1 \mathrm{~cm}$ long; drupes crowned by a short cupular calyx limb (not enlarged) . . . . . . . . . . . . a. subsp. longifolius

1. Leaves glabrous on both surfaces; nervules prominent on both surfaces; corolla longer, up to $2.5 \mathrm{~cm}$ long; drupes crowned by an enlarged cupular calyx limb. . . . . . . . 2

2. Leaves obovate-oblong to lanceolate-oblong, $6-11 \mathrm{~cm}$ broad, apex cuspidate to cuspidate-acute, base cuneate . $\ldots \ldots \ldots \ldots \ldots \ldots \ldots \ldots$ b. subsp. laevis

2. Leaves broadly oblong, $11.5-13.5 \mathrm{~cm}$ broad, the apex rounded, the base subrounded ...... c. var. obtusifolius

\section{a. subsp. longifolius}

Lasianthus longifolius Wight (1846) 514; Hook.f. (1880) 187; King \& Gamble (1904) 116; Ridl. (1923a) 164. - Type: Kew Dist. 2936 (Griffith s.n.) (holo K), Peninsular Malaysia.

Treelets, c. 2 m high; branchlets robust, often compressed, c. 3-5 $\mathrm{mm}$ diam, glabrous. Leaves: blades obovate-oblong to lanceolate-oblong, $20-33$ by $6-11 \mathrm{~cm}$, coriaceous, glabrous above, rigid minute hairs on venation beneath and scabrous (asperate) when touching, apex cuspidate to cuspidate-acute, base cuneate, slightly asymmetric, midrib and nerves slightly 

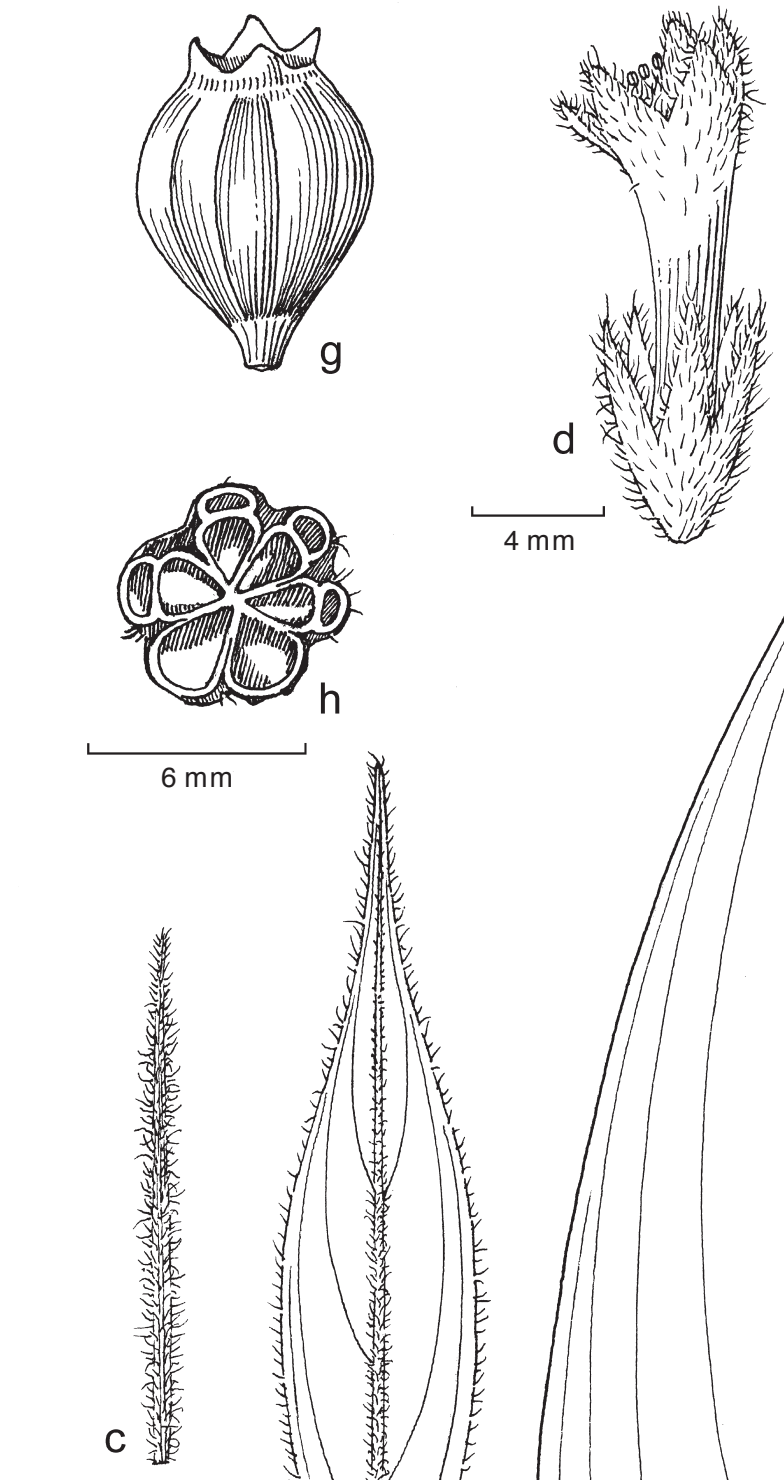

$6 \mathrm{~mm}$
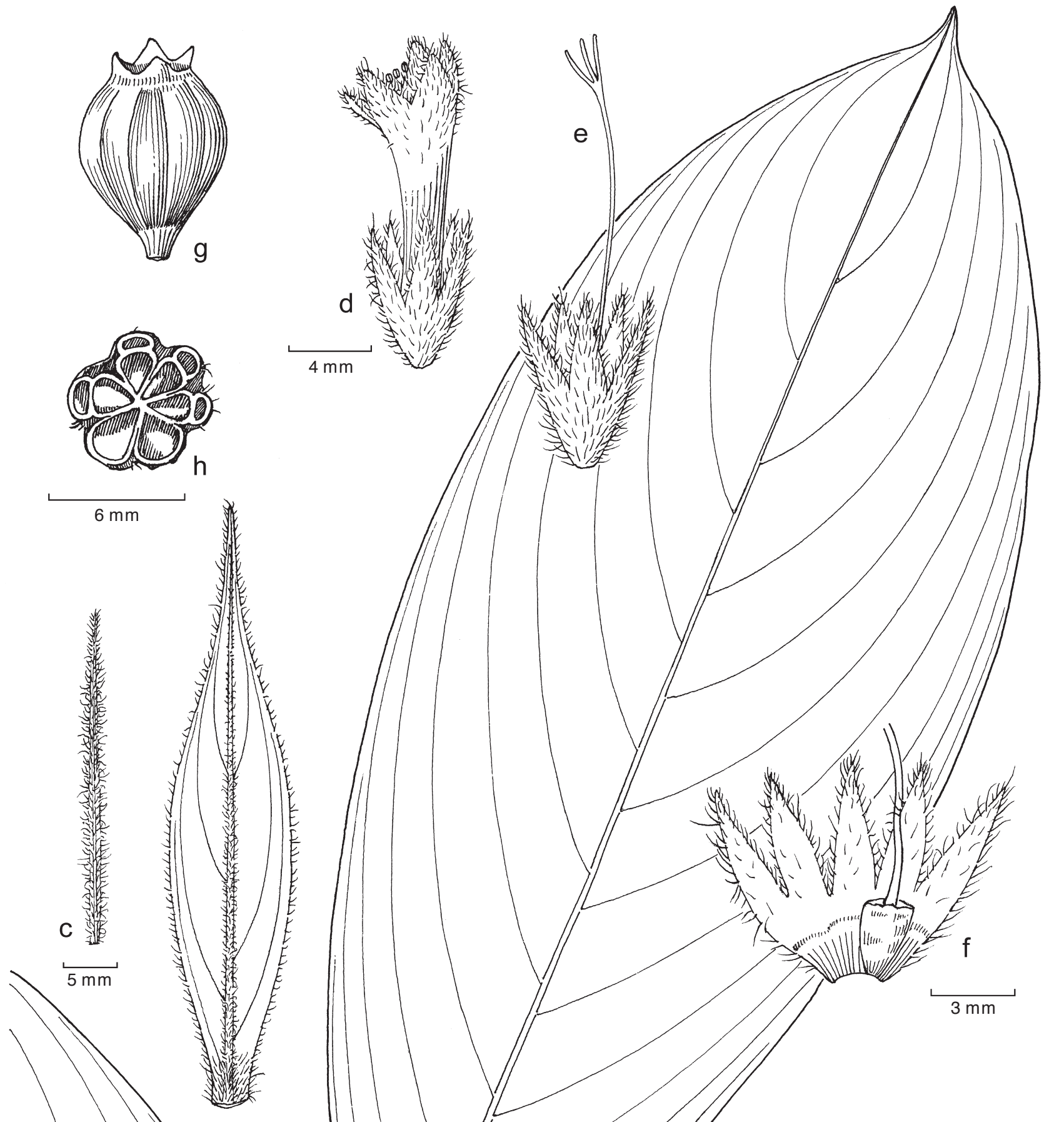


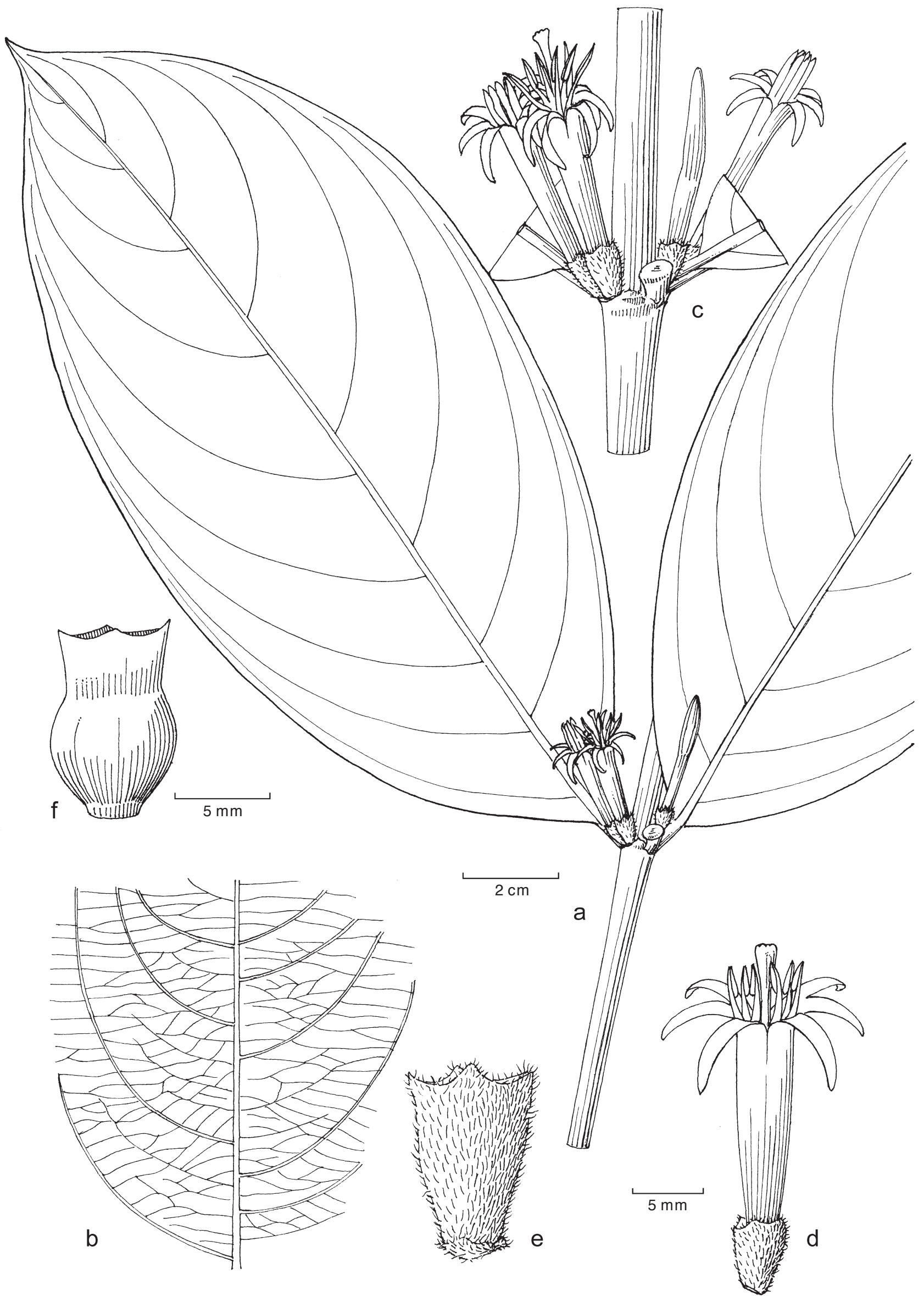

Fig. 22 Lasianthus longifolius Wight subsp. laevis H.Zhu. a. Habit with inflorescences; b. lower surface of leaf showing reticulate nervules; c. detail of node showing axillary inflorescences; d. flower; e. calyx; f. fruit (a-e: C. Hansen 295, holo L; f: Yii et al. S.43146, MO). 
prominent above, strongly prominent beneath, nerves $13-18$ pairs, ascending at an angle of $60-70^{\circ}$, curved to the margin, nervules prominent on both surfaces, reticulate; petioles 5-10 $\mathrm{mm}$ long, glabrous, or sparsely ciliate hairs on the margin. Stipules broadly triangular or oblong-lanceolate, 6-12 mm long, glabrous. Cymes sessile or very short tuberculate; bracts inconspicuous or fewer, small, ovate, hirsute, less than $3 \mathrm{~mm}$ long. Flowers sessile; calyx tube obconical, c. $2 \mathrm{~mm}$ long, glabrous, limb cupular, c. $2 \mathrm{~mm}$ long, glabrous, truncate or with 4-5 triangular teeth which are c. $0.5-1 \mathrm{~mm}$ long and sparsely ciliate at margin; corolla tube c. 5-6 mm long, glabrous, lobes 4-6, lanceolate, c. 4-5 mm long, glabrous outside, densely floccose inside. Drupes subglobose, c. 5-6 mm diam, glabrous, crowned by a usually truncate calyx limb, ridged; pyrenes 6 , ridged on the abaxial face.

Distribution - Peninsular Malaysia and Indonesia (Sumatra).

Note - Lasianthus longifolius differs from L. griffithii by having leaves with rigid minute hairs on venation beneath, oblong-lanceolate stipules not covering the flowers, without numerous filiform bracts except fewer very small ones, flowers with cupular calyx, drupes crowned by a cupular truncate or small dentate calyx limb.

\section{b. subsp. laevis H.Zhu, subsp. nov. - Fig. 22}

A typo foliis glabris nitidis, nervulis subtus et supra prominentibus, corollis usque ad $2.5 \mathrm{~cm}$ longis, drupis limbis calycis dilatatis cupulatis differt. - Typus: Hansen 295 (holo L), Borneo, Sarawak, Gunong Mulu, 200 m alt., in kerangas forest, 7 Feb. 1978

Treelets, branchlets robust, often compressed, glabrous. Leaves: blades obovate-oblong to lanceolate-oblong, 20-33 by $6-11 \mathrm{~cm}$, cuspidate to cuspidate-acute at apex, broadly cuneate at base, coriaceous, glabrous and nitid, with the secondary nerves from the costa between nerves, smooth leaf beneath, nerves 7-12 pairs, nervules prominent on both surfaces. Cymes sessile; bracts inconspicuous or fewer, small. Calyx tube obconical, glabrous, limb cupular; corolla tubular, up to $2.5 \mathrm{~cm}$ long. Drupes 5-6 mm diam, crowned by an enlarged cupular calyx limb, ridged; pyrenes 6 , ridged on the abaxial face.

Distribution - Borneo (Sarawak) and Brunei.

Habitat \& Ecology — In lowland primary forest below $500 \mathrm{~m}$ altitude. Flowering during October to February; fruiting in May.

Additional examined specimens. Sarawak, Ulu Medamit, R. George et al. S.43027 (L); Sarawak, G. Mulu, Paul Chai S.39588; Sarawak, the 4th Division, Othman et al. S.49087 (K). Brunei, Belait, J. Dransfield 6854 (L); Brunei, Bukit Teraja, M.J.E. Coode 6896 (L), D.A. Simpson 2076.
Notes - This subspecies differs from the typical subspecies by having glabrous and nitid leaves with the secondary nerves from the costa between nerves, smooth leaf beneath, nervules prominent on both surfaces, corolla up to $2.5 \mathrm{~cm}$ long, crowned by an enlarged cupular calyx limb. While the typical subspecies has leaves beneath with rigid minute hairs on venation and scabrous (asperate) when touching, nervules conspicuously prominent beneath, corolla less than $1 \mathrm{~cm}$ long, drupes crowned by a short cupular calyx limb (not enlarged).

This subspecies was treated as the typical subspecies. However, the specimens from Borneo are different from the ones from Peninsular Malaysia and Sumatra. The specimens from Peninsular Malaysia and Sumatra agree well with the type, while the ones from Borneo are different as discussed above. It is better to recognise the specimens from Borneo as a new subspecies.

From specimens annotated labels, this taxa has calyx white, petals reflexed, with long violet hairs on inner surface.

\section{c. var. obtusifolius H.Zhu, var. nov.}

A typo foliis late-oblongis apice rotundatis basi subrotundatis differt. - Typus: Wong 1569 (holo L), Brunei, Belait, in primary forest, 7 Oct. 1989.

Treelets, branchlets robust, often compressed, glabrous. Leaves broadly oblong, $22-28$ by $11.5-13.5 \mathrm{~cm}$ rounded at apex and subrounded at base, coriaceous, glabrous and nitid, with the secondary nerves from the costa between nerves, nerves 7-10 pairs, nervules prominent beneath.

Distribution - Endemic to Brunei.

Habitat \& Ecology — In primary forest. Flowering and fruiting in October.

Note - This variety differs from the typical variety by having broadly oblong leaves with rounded apex and subrounded base, $22-28$ by $11.5-13.5 \mathrm{~cm}$.

\section{Lasianthus lucidus Blume - Map 9}

Lasianthus lucidus Blume (1826-1827) 997; Miq. (1857) 319; Kurz (1877) 30; Hook.f. (1880) 184; Pit. (1924) 385; Craib (1934) 214; Bakh.f. (1965) 342; Deb \& M.Gangop. (1991) 290, f. 6, exclud. var. caudisepalus Deb \& M.Gangop.; H.Zhu (1994) 63; (1998) 153; H.S.Lo (1999) 88; H.Zhu (2001b) 135; (2002) 84. - Mephitidia lucida (Blume) DC. (1830) 453. - Type: Blume s.n. (lecto L, designated by Zhu 2002, barcode L0000697); Blume s.n. (para L, barcode L0305289), Java.

Shrubs, 1-1.5 m high; branches and branchlets glabrous or sparsely strigose on very young parts. Leaves: blades ovate,

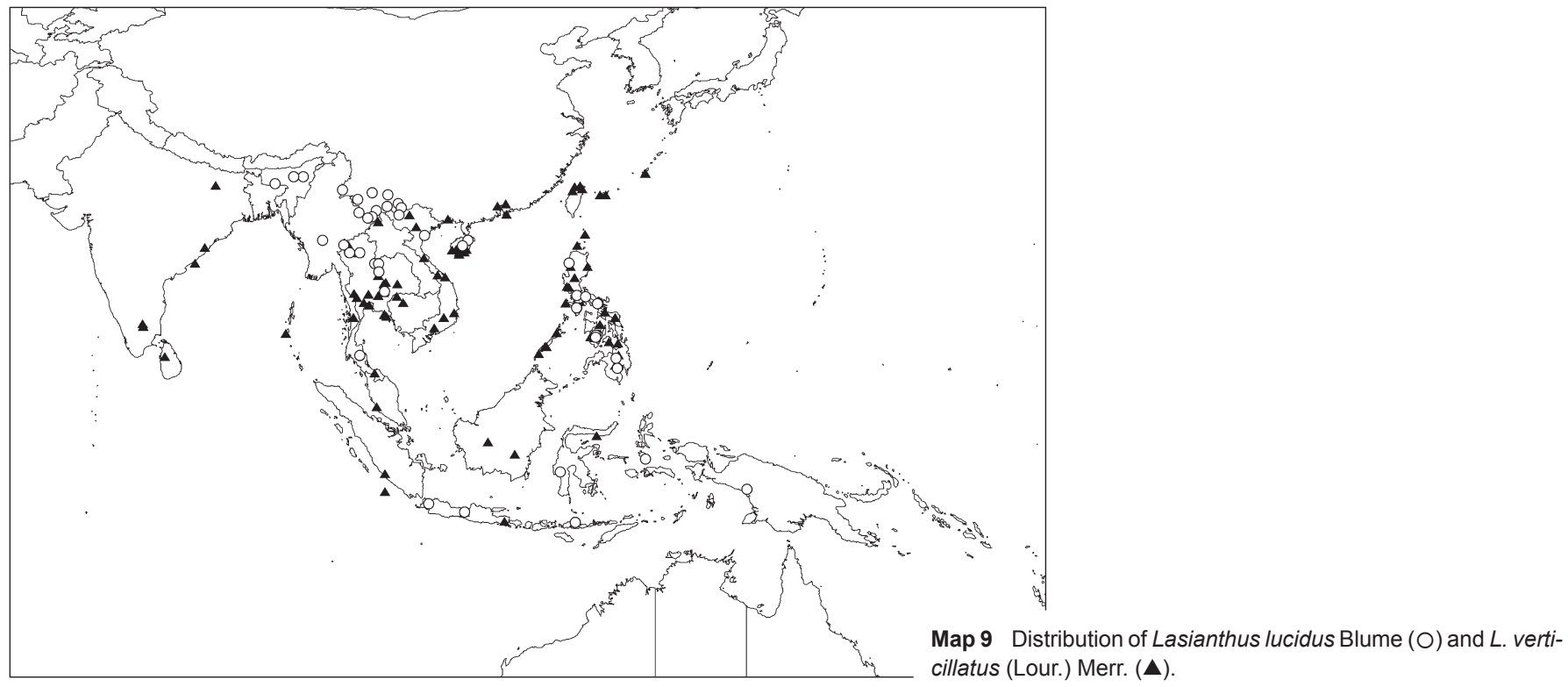


ovate-elliptic, $4-9$ by $1.5-3 \mathrm{~cm}$, membranaceous or subcoriaceous, glabrous above, sparsely strigose or hirsute on nerves and nervules beneath, apex acuminate or cuspidate-acuminate, base cuneate, midrib and nerves flat above, prominent beneath, nerves $3-4$ pairs, ascending at an angle of $45-60^{\circ}$, curved to the margin, nervules slightly obscure above, distinct beneath, parallel; petioles $5-8 \mathrm{~mm}$ long, usually strigose. Stipules triangular, c. $1 \mathrm{~mm}$ long, strigose. Cymes sessile; bracts absent. Flowers sessile; calyx widely campanulate, with lanceolate lobes, tube c. $1 \mathrm{~mm}$ long, subglabrous, lobes 5 , c. $2-3 \mathrm{~mm}$ long, usually strigose outside and at the tip, glabrous inside; corolla glabrous to strigose outside, villous at throat inside. Drupes globose or ovoid, crowned with persistent calyx lobes, glabrous, 4-5 mm diam; pyrenes 5 .

Distribution - NE India, Burma, China, Vietnam, Thailand, Malaysia, Philippines, Indonesia (Java, Lesser Sunda Islands, Sulawesi, Moluccas, Irian Jaya), New Guinea.

Note - Lasianthus lucidus is similar to L. fordii. Lasianthus lucidus has small ovate to ovate-elliptic leaves and lanceolate calyx lobes which are longer than the tube, while $L$. fordii has small ovate-lanceolate to larger ovate-oblong leaves and minute triangular calyx lobes which are shorter than the tube.

\section{Lasianthus malaccensis King \& Gamble}

Lasianthus malaccensis King \& Gamble (1904) 124; Ridl. (1923a) 165; K.M.Wong (1989) 368. - Type: Ridley 3219 (holo SING), Peninsular Malaysia.

Lasianthus flavinervius auct non Ridl.: Craib (1934) 211.

Shrubs or treelets; branchlets terete, c. $1.5 \mathrm{~mm}$ diam, puberulous, very dark in colour when dry. Leaves: blades oblonglanceolate, $7-13$ by $2-3.5 \mathrm{~cm}$, coriaceous, glabrous above, appressed-pubescent hairs on midrib and nerves beneath, dark olivaceous-brown when dry, apex acuminate, margin reflected, base cuneate or acute, midrib and nerves slightly prominent above, prominent beneath, nerves $7-10$ pairs, ascending at an angle of over $50^{\circ}$, curved to the margin, nervules distinct on both surfaces, reticulate; petioles $4-7 \mathrm{~mm}$ long, puberulous. Stipules triangular, the base broad, abruptly narrowed into the triangular apex, c. $1.5 \mathrm{~mm}$ long, puberulous. Cymes sessile; bracts absent. Flowers sessile; calyx campanulate-cupular, puberulous, c. $1.5 \mathrm{~mm}$ long, wide and minutely 5-toothed. Drupes subglobose, glabrous, crowned by $5-6$ obtuse short calyx teeth; pyrenes 4-5, smooth.

Distribution - Southern Thailand, Peninsular Malaysia.

Note - Lasianthus malaccensis is closely related to L. chinensis, especially the reticulate nervules and reflected leaf margins. It differs from the latter by having young branchlets puberulous, glabrescent, relatively smaller lanceolate to ovatelanceolate leaves with acute to acuminate apex, midrib and nerves minutely appressed-pubescent beneath, less nerves (8-9 pairs), and smaller drupes. It is also closely related to $L$. wightianus, but differs from the latter by having young branchlets puberulous and later glabrescent, midrib and nerves minutely appressed-pubescent beneath, nerves 7-9 pairs, stipules relatively small.

\section{Lasianthus malaiense H.Zhu}

Lasianthus malaiense H.Zhu (2000a) 257. - Type: Henderson 18008 (holo SING), Peninsular Malaysia, Pahang, Cameron's Highlands, alt. $5000 \mathrm{ft}$, 27 Nov. 1925

Shrubs, c. $2 \mathrm{~m}$ high; branchlets terete, or slightly compressed in the youngest part, robust, c. $3 \mathrm{~mm}$ diam, densely spreading brown-villose. Leaves: blades ovate-oblong to elliptic, $6-15$ by $2.5-5.5 \mathrm{~cm}$, subcoriaceous, glabrous above, densely spreading brown-villose beneath, apex acute to cuspidate, base rounded or obtuse, margin reflexed, midrib and nerves flat or slightly depressed above, conspicuously prominent beneath, nerves $7-10$ pairs, ascending at an angle of $50-60^{\circ}$, curved to the margin; nervules distinct above, prominent beneath, parallel; petiole c. $5 \mathrm{~mm}$ long, densely spreading brown-villose. Stipules triangular, c. $3 \mathrm{~mm}$ long, spreading brown-villose. Cymes peduncled; peduncles robust, $2-3 \mathrm{~cm}$ long; bracts 2 , linear, 7-8 mm long; bracteoles inconspicuous. Flowers subsessile; calyx 3-4 mm long with 5 lanceolate lobes, lobes c. $2.5 \mathrm{~mm}$ long; corolla brown-villose. Drupes subglobose, c. $5 \mathrm{~mm}$ diam, crowned by persistent calyx lobes; pyrenes 5 .

Distribution - Peninsular Malaysia, Indonesia (Sumatra).

Note - Lasianthus malaiense differs from L. robinsonii in having leaves brown-villose beneath, nervules parallel, petioles up to $5 \mathrm{~mm}$ long; robust peduncles $2-3 \mathrm{~cm}$ long; flowers 5-merous, calyx lobes lanceolate, $2.5 \mathrm{~mm}$ long. It differs from $L$. pendulus by ovate-oblong leaves with caudate apex and rounded base, nerves flat above, nervules parallel, petioles 5 $\mathrm{mm}$ long; bracts 2, 7-8 mm long, calyx lobes lanceolate, 2.5 $\mathrm{mm}$ long and corolla hairy.

\section{Lasianthus megaphyllus H.Zhu, sp. nov. - Fig. 23}

Similis L. griffithii Wight, sed stipulis triangulatis minoribus, foliis basi rotuondatis vel subcordatis, petiolis brevioribus, bracteis ovatis differt. - Typus: Nooteboom 4340 (holo L), Borneo, Bukit Raya, 130 m alt., in primary dipterocarp forest, 17 Dec. 1982.

Small tree, $2 \mathrm{~m}$ high; branchlets robust, c. 4-5 mm diam, subangulose, fistulose, incrassate at nodes, glabrous. Leaves: blades elliptic-oblong, large, $22-30$ by $7-12 \mathrm{~cm}$, coriaceous, glabrous on both surfaces, apex acute to cuspidate, margin slightly recurved, base rounded to subcordate, midrib slightly prominent above, conspicuously prominent beneath, sparsely hirsute or glabrescent beneath, nerves flat above, prominent beneath, $12-16$ pairs, ascending at an angle of $60-70^{\circ}$, curved to the margin, hirsute to glabrescent beneath, nervules conspicuous above and very prominent beneath, subreticulate, appressed-hirsute or subglabrous beneath; petioles subsessile or short, 4-5 mm long, sparsely hirsute. Stipules triangular, subcoriaceous, up to $1 \mathrm{~cm}$ long, 3-6 $\mathrm{mm}$ broad at base, brown hirsute. Inflorescences sessile; bracts conspicuous, ovate, 5-6 by $4-5 \mathrm{~mm}$, hirsute external surface; bracteoles lanceolate to linear, 5-6 mm long, densely hirsute. Flowers not seen. Drupes subglobose, blue when fresh, $5-6$ by $5-6 \mathrm{~mm}$, conspicuously 6-ridged, verrucose, glabrous except hirsute upper part, crowned by 5-6 triangular-lanceolate, $1.5 \mathrm{~mm}$ long, hirsute, persistent calyx lobes; pyrenes 6 , verrucose on the abaxial face, grooved on the adaxial face.

Distribution - Borneo.

Habitat \& Ecology — In lowland rainforest (below 200 m altitude). Fruiting from July to December.

Additional specimens examined. Borneo, Tumbang, Veldkamp 8144 (L); Sarawak, B. Lee S.40652 (L), B. Lee S.54735 (K, L), P. Chai et al. S.33331 (L), Othman et al. S.41248 (K, L), Othman et al. S.56055 (K, L); W Kalimantan, J.S .Burley et al. 2894 (K, L); Liang Gagang, H. Hallier 3083 (L); Bukit Raya, Nooteboom 4203 (L); E Borneo, A. Kostermans 10493 (K, L); Borneo, Amdjah 19 (L); Kalimantan Selatan, K. Kartawinata 705 (L); Borneo, F.H. Endert 2661 (K, L), H. Hallier 3289 (L).

Note - This species is close to $L$. griffithii. It differs from the latter by having triangular stipules, $8-10$ by $3-6 \mathrm{~mm}$; leaves with rounded to subcordate base; shorter petioles; less dense ovate bracts. Lasianthus griffithii has big ovate-orbicular stipules, usually more than 1 by $1 \mathrm{~mm}$; leaves with cuneate base; relatively long petioles and very dense linear bracts. 


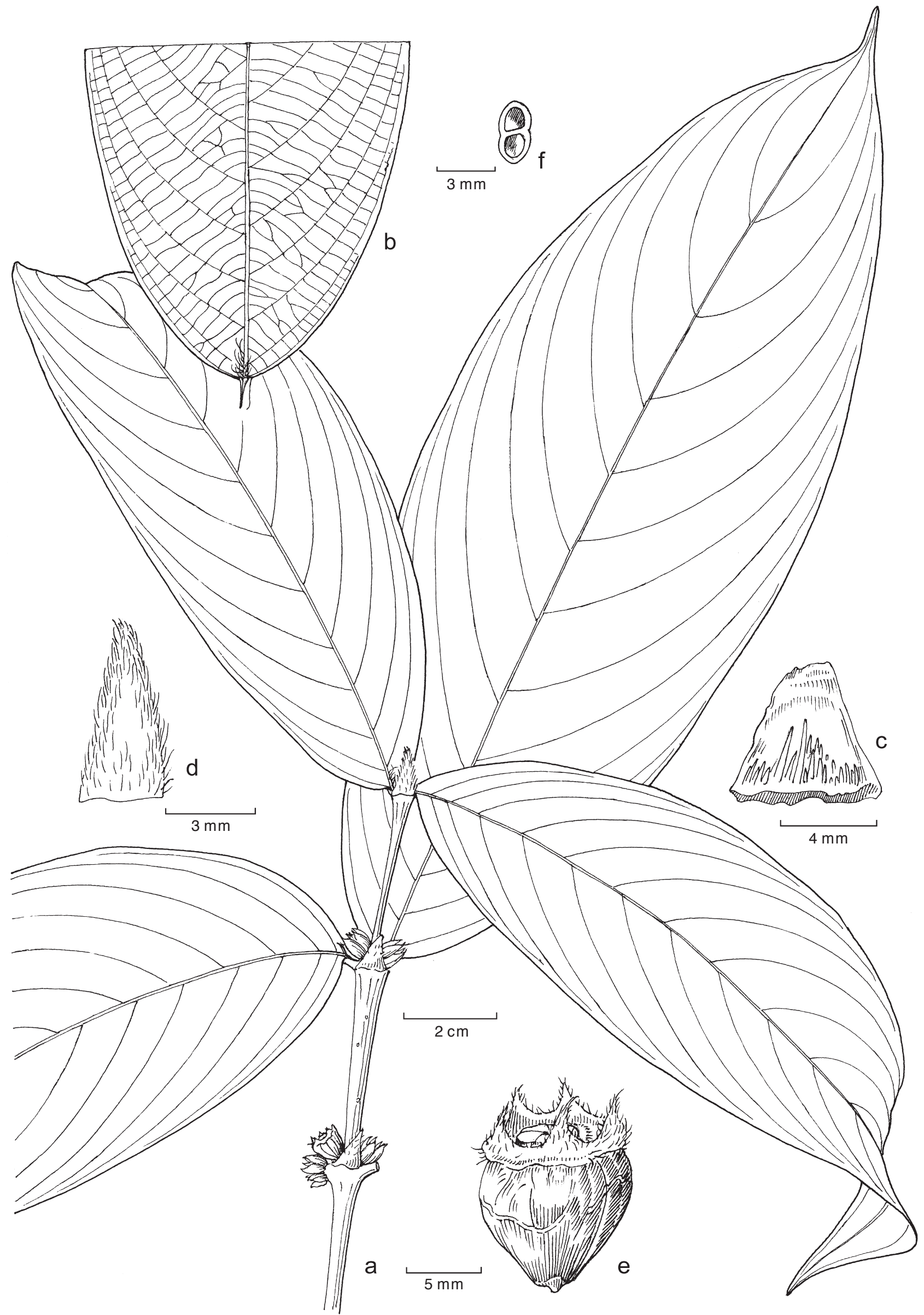

Fig. 23 Lasianthus megaphyllus H.Zhu. a. Habit with inflorescences; b. detail of lower surface of leaf showing subreticulate nervules; c. stipule; d. bract; e. fruit; f. cross section of pyrene (all: Nooteboom 4340, holo L). 


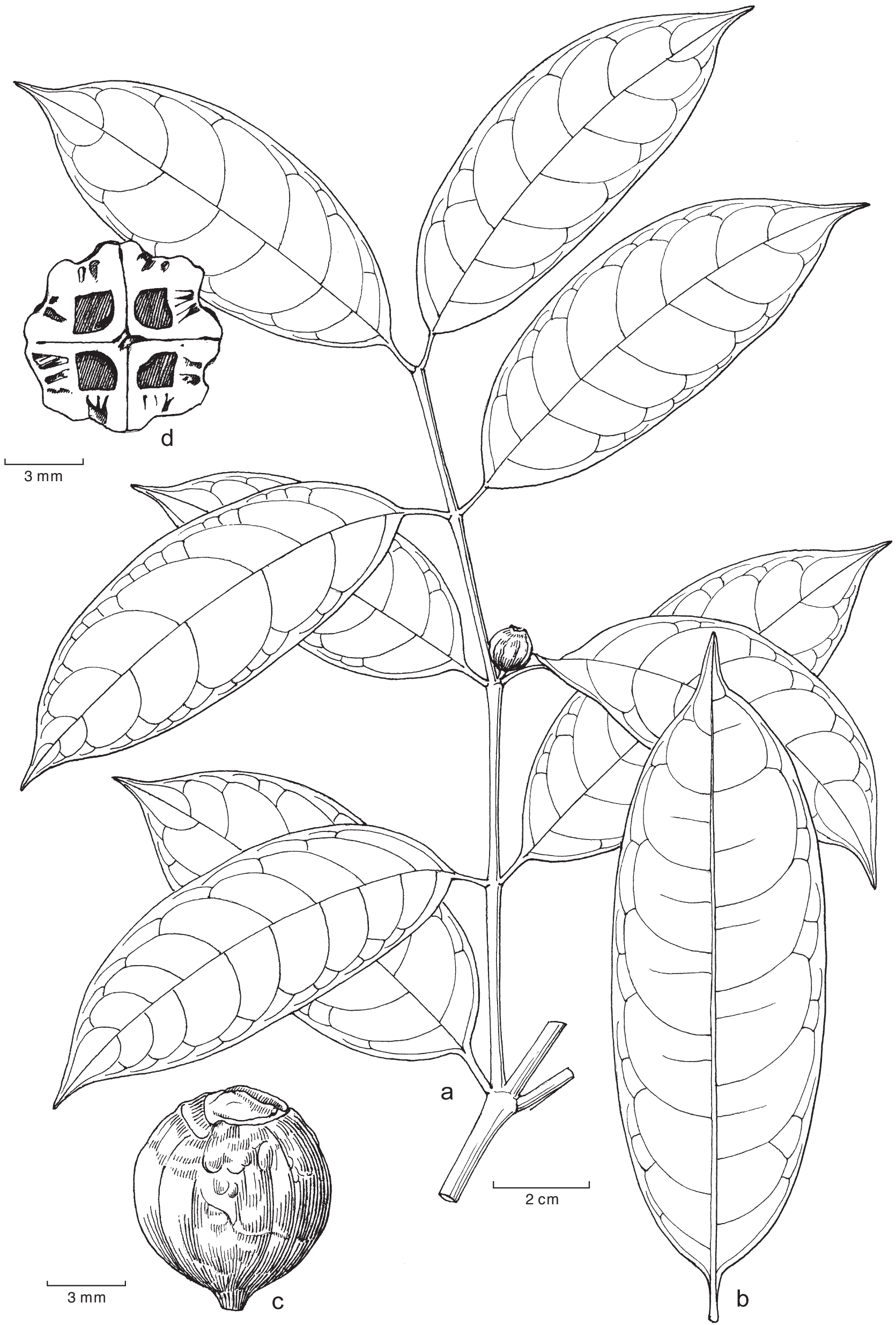

Fig. 24 Lasianthus membranaceoideus H.Zhu. a. Habit with inflorescence; b. leaf; c. fruit; d. cross section of fruit (all: J. Dransfield et al. 6537, holo L). 


\section{Lasianthus membranaceoideus H.Zhu, sp. nov. - Fig. 24}

A L. membranaceo Stapf foliis coriaceis, venationibus brachidodromibus, stipulis inconspicuis, bracteis inconspicuis, fructibus globosis conspicue octogonis, pyrenis 4 differt. - Typus: Dransfield et al. 6537 (holo L; iso K), Brunei, Belait, $50 \mathrm{~m}$ alt., in primary mixed dipterocarp forest, 5 June 1989.

Small tree, up to $3 \mathrm{~m}$ high, branchlets terete, $2 \mathrm{~mm}$ diam, glabrous. Leaves: blades oblong, $9-11$ by $3-4 \mathrm{~cm}$, coriaceous, glabrous, apex cuspidate, base subrounded to cuspidate, midrib depressed above, prominent beneath, nerves prominent on both surfaces, 6-8 pairs, combinate venous, ascending at an angle of almost $90^{\circ}$, curved near the leaf margin and joining the veins above forming an intramarginal vein, internerved veins conspicuous, ascending from the midrib at a right angle, combination to the main nerves; nervules conspicuous on both surfaces, reticulate; petioles 6-10 $\mathrm{mm}$ long, glabrous. Stipules inconspicuous. Inflorescences sessile or forming a very short tubercle; bracts inconspicuous. Flowers sessile, very small; immature flowers only $1 \mathrm{~mm}$ long, 4-merous; calyx campanulate, glabrous, lobes ovate-triangular, $0.3-0.5 \mathrm{~mm}$ long; corolla glabrous on external surface, lobes 4 , ovate, 0.5 $\mathrm{mm}$ long; anthers 4. Drupes globose, c. $7 \mathrm{~mm}$ diam, conspicuously 8-ridged, glabrous, rugose; pyrenes 4 , rarely 3 , with two irregular sulcae on the abaxial face of the pyrene, subrhombic in transverse section, and with very thick-walled abaxial side.

Distribution - Endemic to Borneo.

Habitat \& Ecology — In lowland rainforest between 50$300 \mathrm{~m}$ altitude. Flowering and fruiting between March and June.

Additional specimen examined. Borneo, Sabah, Lumaku, Nooteboom $1167(\mathrm{~L})$.

Note - This species is close to L. membranaceus. It differs from the latter by having coriaceous leaves with combinate venous nerves forming looped venation; stipules inconspicuous; drupes globose with 8 ridges, pyrenes 4; each pyrene with 2 irregular sulcate on the abaxial face. Lasianthus membranaceus has membranaceous to subcoriaceous leaves without conspicuous looped venation; stipules triangular, $3 \mathrm{~mm}$ long; drupes verrucose, without conspicuous ridges; pyrenes usually 2 , rarely 3-4; pyrene without 2 sulcae on the abaxial face.

\section{Lasianthus membranaceus Stapf}

Lasianthus membranaceus Stapf (1894) 184; Merr. (1921) 578. - Type: Haviland 1336 (lecto K, designated here; isolecto SING); Haviland 1300 (para K), Borneo, Penokok, $3000 \mathrm{ft}$.

Lasianthus membranaceus Stapf var. firma Stapf (1894) 185; Merr. (1921) 578, syn. nov. - Type: Haviland 1241 (holo K), Borneo, Kadamaian, $5000 \mathrm{ft}$.

Shrubs, up to $2 \mathrm{~m}$ high, glabrous; branchlets terete, sometimes compressed in the youngest part, c. $2 \mathrm{~mm}$ diam. Leaves: blades oblong to elliptic-oblong or obovate-oblong, $11-22$ by $4-7 \mathrm{~cm}$, membranaceous, apex cuspidate, base broadly cuneate or cuspidate-acute, slightly asymmetric, midrib and nerves flat to slightly prominent above, prominent beneath, nerves 4-7 pairs, ascending at an angle of over $60^{\circ}$, curved to the margin, nervules loosely anastomosing, weak at both surfaces, reticulate; petioles $5-10 \mathrm{~mm}$ long. Stipules triangular, up to $3 \mathrm{~mm}$ long, glabrous or ciliate at tip. Cymes sessile or very short tuberculate; bracts inconspicuous or linear, usually $3 \mathrm{~mm}$ long, glabrous or hirsute. Flowers sessile; calyx tube obconical, c. $1 \mathrm{~mm}$ long, glabrous, limb c. $0.5 \mathrm{~mm}$ long, glabrous, with minute 4 subulate teeth; corolla tube c. $5 \mathrm{~mm}$ long, glabrous outside, lobes 4, linear-oblong, c. 2 mm long; anthers 4; ovary 4-locular. Drupes ovoid, c. $10 \mathrm{~mm}$ long, glabrous, verrucose; pyrenes $2-4$, with thick warty wall.

Distribution — Malaysia (Borneo), Brunei.
Note - This species has glabrous oblong leaves, 4-merous flowers, calyx with 4 triangular teeth, ovary 4-locular, drupes with 2-4 pyrenes. The variety firma cannot clearly be distinguished from the typical variety and should be reduced to synonymy. Lasianthus membranaceus differs from L. kinabaluensis by larger leaves with rounded bases. Lasianthus membranaceus occurs mainly on low land and lower montane rainforest below $1500 \mathrm{~m}$ altitude, while L. kinabaluensis occurs mainly in upper montane rainforest over $1200 \mathrm{~m}$ altitude.

\section{Lasianthus minutiflorus H.Zhu, sp. nov. - Fig. 25}

Proximus L. phymatodeus H.Zhu, sed foliis conspicue majoribus $15-28 \mathrm{~cm}$ longis $3.5-5 \mathrm{~cm}$ latis, nervis $7-10$-binatis, calycibus densely hirsutis, drupis levigatis et pyrenis abaxialiter levigatis differt. - Typus: Buwalda 6546 (holo L), Sumatra, Derapit (C Sumatra), in primary forest.

Treelet, 1.5-2 m high; branchlets terete, 1.5-2 mm diam, glabrous, brown. Leaves: blades ovate-lanceolate to ovate elliptic, coriaceous, $15-28$ by $3.5-5 \mathrm{~cm}$, glabrous on both surfaces, apex caudate, mucronate, margin slightly recurved, base acute or cuneate; midrib slightly prominent above, strongly prominent beneath, nerves flat above, prominent beneath, 7-10 pairs, ascending at an angle of $60-70^{\circ}$, curved to margin; nervules parallel, prominent on both surfaces, conspicuous beneath; petioles c. $1 \mathrm{~cm}$ long, glabrous or sparsely puberulous, darkbrown. Stipules triangular, $1.5-3 \mathrm{~mm}$ long, puberulous, bristles from the inside base of stipules existent, c. $0.5 \mathrm{~mm}$ long. Inflorescences extremely congested; bracts inconspicuous. Flowers sessile, extremely small; calyx c. $1 \mathrm{~mm}$ long, densely hirsute, lobes $4-5$, triangular-subulate, $0.5 \mathrm{~mm}$ long, densely hirsute on external surface; corolla not seen. Drupes subglobose, $4-5 \mathrm{~mm}$ diam, subglabrous, smooth, with $4-5$ obtuse ridges; pyrenes $4-5$, smooth on the abaxial face, sulcate on sides, ovate in the transverse section.

Distribution - Malaysia (Peninsular), Indonesia (Sumatra).

Habitat \& Ecology — In lowland and lower montane primary forest. Flowering and fruiting between February and April.

Additional specimens examined. N Sumatra, Langkat, Soedarsono 250 (K, L), Soedarsono 327 (K, L). Peninsular Malaysia, Pahang, KEP-FRI 6443 (L); Ulu Kelantan, KEP-FRI 5476 (L); Kelantan, M.R. Henderson 19732 (K).

Note - This species is characterized by its extremely small flowers fascicled in the extremely congested cymes. It seems close to $L$. phymatodeus, but differs from the latter by having leaves conspicuously big ( $15-28$ by $3.5-5 \mathrm{~cm})$, with $7-10$ pairs of nerves, calyx densely hirsute, drupes smooth on surface, pyrenes smooth on the abaxial face, sulcate on sides from cross section view. Lasianthus phymatodeus has leaves $8-12$ by $2-3.5 \mathrm{~cm}$, with $4-5$ pairs of nerves, calyx sparsely puberulous or glabrous, drupes strongly warty; pyrenes irregularly sharp ridges on all sides from cross section view.

\section{Lasianthus mollis Ridl.}

Lasianthus mollis Ridl. (1920) 144; (1923a) 158; K.M.Wong (1989) 373. — Type: Ridley s.n. (holo SING; iso K), Peninsular Malaysia, Tebong.

Shrubs; branchlets terete, 1.5-2 mm diam, densely pubescent. Leaves: blades elliptic, $8-11$ by $3-3.5 \mathrm{~cm}$, thinly coriaceous, glabrous above except pubescent hairs on midrib, pubescent hairs on venation beneath, apex acuminate to caudate-acute, base cuneate, midrib and nerves slightly prominent above, prominent beneath, nerves $5-8$ pairs, ascending at an angle of $45-50^{\circ}$, curved to the margin, nervules distinct on both surfaces, parallel; petioles $0.8-1 \mathrm{~cm}$ long, densely pubescent. Stipules lanceolate, usually up to $5 \mathrm{~mm}$ long, densely pubescent. Cymes sessile; bracts small, lanceolate, 2-3 mm long, densely long-pubescent. Flowers sessile; calyx c. 2 mm long, 


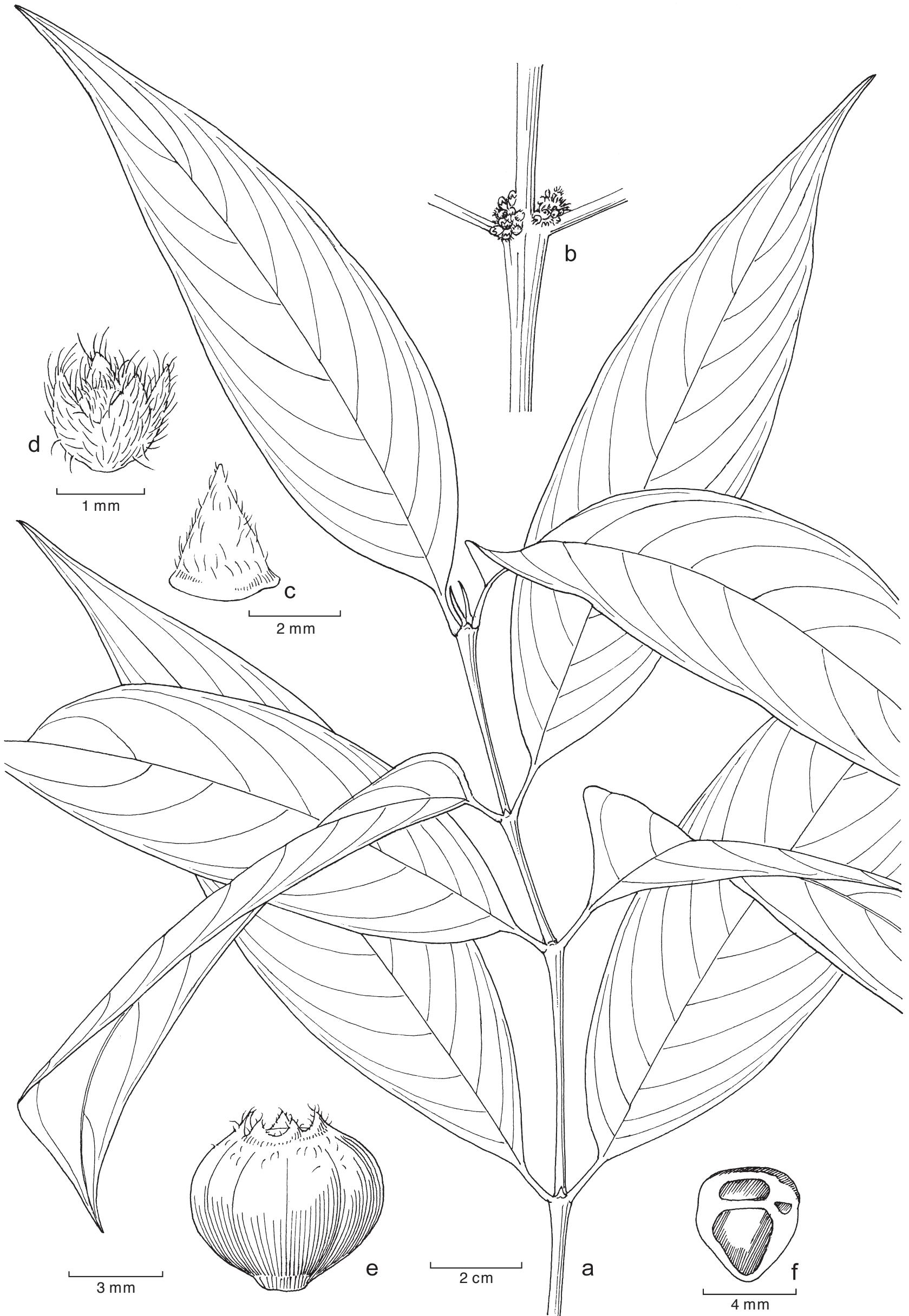

Fig. 25 Lasianthus minutiflorus H.Zhu. a. Habit; b. detail of node showing axillary inflorescences; c. stipule; d. calyx; e. fruit; f. cross section of pyrene (all: Buwalda 6546, holo L). 
with an obconical tube and campanulate limb, tube $0.8-1 \mathrm{~mm}$ long, glabrous, limb with 4 lanceolate lobes which are $0.6-8$ $\mathrm{mm}$ long and hirsute; corolla $8-10 \mathrm{~mm}$ long, tube glabrous outside, villose inside, lobes 4 , hairy on both sides. Drupes oblong, $5 \mathrm{~mm}$ diam, puberulous; pyrenes 4-5.

Distribution - Peninsular Malaysia, Indonesia (Sumatra).

Note - This species is very close to $L$. chrysoneurus but differs from the latter by having relatively small leaves, stipules and bracts, and denser but less appressed pubescence.

\section{Lasianthus mucronulatus (Korth.) Miq.}

Lasianthus mucronulatus (Korth.) Miq. (1857) 325; (1869) 249. - Mephitidia mucronulata Korth. (1851) 222. - Type: Korthals s.n. (lecto L, designated here, barcode L0057756), Sumatra, Singalang; Korthals s.n. (para, n.v.), Borneo, Balaran, and Pamaton.

Lasianthus palembanicus Miq. (1861) 549. - Lasianthus stercorarius Blume var. palembanicus (Miq.) Miq. (1869) 248. - Type: Teysmann s.n. (holo U), Sumatra, Palembang, Ogan-ulu.

Lasianthus stercorarius Blume var. borneensis Miq. ex Valeton \& Winkler (1910) 569, syn. nov. - Type: Winkler 2216 (n.v.), Borneo.

Shrubs to treelets; branchlets terete, c. $2 \mathrm{~mm}$ diam, puberulous, dark-brown when dry. Leaves: blades oblong-lanceolate, 10-12 by $2-4 \mathrm{~cm}$, chartaceous, glabrous or sparsely pubescent hairs on midrib above, pubescent hairs on venation beneath, apex caudate-acuminate or acuminate, margin slightly undulate and reflexed, base broadly cuneate to subrounded, slightly asymmetric, midrib and nerves slightly prominent on both surfaces, nerves slender, 10-16 pairs, ascending at an angle of $45-60^{\circ}$, curved to the margin; nervules distinct on both surfaces, reticulate; petioles 2-4 mm long, puberulous. Stipules triangular, usually $2 \mathrm{~mm}$ long, puberulous. Cymes sessile; bracts absent. Flowers sessile; obconic-campanulate; calyx tube c. $0.8 \mathrm{~mm}$ long, glabrous or pubescent, calyx limb c. $0.6 \mathrm{~mm}$ long, with 4-5 minute and pubescent teeth; corolla pubescent outside, tube c. $2 \mathrm{~mm}$ long, lobes c. $1 \mathrm{~mm}$ long. Drupes globose, c. 3 $\mathrm{mm}$ diam, puberulous or subglabrous; pyrenes 5 .

Distribution — Indonesia (Sumatra, Java, Kalimantan).

Notes - This species differs from $L$. stercorarius by having usually relatively large chartaceous leaves with broadly cuneate to subrounded bases and more than 10 paired nerves and small, $2 \mathrm{~mm}$ long, triangular stipules and smaller drupes without a truncate calyx limb.

Lasianthus mucronulatus var. lineata was established on Korthals's Sumatra specimens. It has triangular stipules with swollen base, subcoriaceous leaves with much acute base which are the same as $L$. stercorarius. Var. lineata here is reduced to L. stercorarius.

Lasianthus stercorarius var. borneensis is the same as L. mucronulatus morphologically as pointed by Valeton \& Winkler. It is here reduced to a synonym of $L$. mucronulatus.

\section{Lasianthus myrtifolius Ridl.}

\section{Key to the subspecies}

1. Leaves ovate-lanceolate or ovate with a caudate-acuminate apex; calyx and corolla pubescent .. a. subsp. myrtifolius

1. Leaves oblong with an abruptly acute apex; calyx and corolla glabrous................ b. subsp. vicarius

\section{a. subsp. myrtifolius}

Lasianthus myrtifolius Ridl. (1909) 35; (1923a) 161; K.M.Wong (1989) 369. - Type: Ridley 13630 (holo SING; iso K), Peninsular Malaysia, Pahang, $5000 \mathrm{ft}$.
Shrubs, 1-2 m high; branchlets terete, slender, c. $1 \mathrm{~mm}$ diam, puberulous. Leaves: blades ovate-lanceolate to ovate, $3-7$ by 1-2 cm, coriaceous, glabrous and nitid on both surfaces, or minutely puberulous hairs on midrib and nerves beneath, apex caudate-acuminate, aristate, arista c. $1 \mathrm{~mm}$ long, base acute, midrib slightly depressed above, prominent beneath; nerves prominent on both surfaces, 5-6 pairs, ascending at an angle of over $45^{\circ}$, curved to the margin, nervules prominent and distinct on both surfaces, parallel; petioles 3-5 $\mathrm{mm}$ long, puberulous. Stipules subulate-triangular, c. $1 \mathrm{~mm}$ long, pubescent. Cymes sessile; bracts absent. Flowers sessile; calyx campanulate, c. 2 $\mathrm{mm}$ long, pubescent outside, lobes 4, triangular, c. $1 \mathrm{~mm}$ long; corolla c. $5 \mathrm{~mm}$ long, lobes 4 , linear, pubescent outside, hairy inside. Drupes globose, c. $4 \mathrm{~mm}$ diam, verrucose, conspicuously 4-ridged; pyrenes 4 , sulcate on the abaxial face and sides.

Distribution - Endemic to Peninsular Malaysia.

Note - This species has small thickly coriaceous leaves, which look like myrtaceous leaves, and very small flowers.

\section{b. subsp. vicarius H.Zhu, subsp. nov. - Fig. 26}

A typo foliis majoribus oblongis apice abrupte acutis, calycibus et corollis extus glabris differt. Similis L. coriaceifolius H.Zhu, sed nervulis foliorum parallelis, calycibus minoribus, lobis calycis triangularibus, drupis non conspicue porcatis, pyrenis abaxiali laevigatis differt. - Typus: Banying ak Nyudong S.19397 (holo L), Borneo, Naoung, Anap, 1150 m alt., in submontane heath forest, 11 Oct. 1963.

Treelet, 5-6 m high; branchlets terete, robust, c. $2.5 \mathrm{~mm}$ diam, glabrous, darkish. Leaves: blades oblong, $4.5-7.5$ by $2-3$ $\mathrm{cm}$, thickly coriaceous, glabrous, apex abruptly acute, margin recurved, base acute, midrib, nerves and nervules prominent on both surfaces, nerves 6-8 pairs, nervules parallel; petioles c. $3 \mathrm{~mm}$ long, glabrous, darkish. Stipules triangular-subulate, $1.5 \mathrm{~mm}$ long, subglabrous. Inflorescences sessile; bracts small, ovate, $1 \mathrm{~mm}$ long or inconspicuous. Flowers sessile; calyx campanulate, 2-3 mm long, glabrous, darkish, lobes 4 , triangular, c. $1 \mathrm{~mm}$ long; corolla $4-5 \mathrm{~mm}$ long, glabrous on external surface, darkish, lobes ovate-triangular, $1 \mathrm{~mm}$ long. Drupes subglobose, c. $4 \mathrm{~mm}$ diam, glabrous, crowned by calyx lobes; pyrenes 4, smooth on abaxial face, suborbicular in the transverse section.

Distribution - Borneo (Sarawak).

Habitat \& Ecology - Submontane heath forest or mossy forest on the summit over $1100 \mathrm{~m}$ altitude. Flowering and fruiting between May and October. $(\mathrm{K}, \mathrm{L})$

Additional specimen examined. Sarawak, Bantulu, E.F. Brunig S. 8770

Note - This subspecies differs from the typical subspecies by having oblong leaves with abruptly acute apex, glabrous calyx and corolla external surface. The typical subspecies has ovate-lanceolate or ovate leaves with caudate-acuminate apex, pubescent calyx and corolla external surface. It differs from $L$. coriaceifolius by having leaves with parallel nervules, calyx relatively small (2-3 mm long), calyx lobes triangular, drupes without conspicuous ridges, pyrenes smooth on abaxial face. Lasianthus coriaceifolius has leaves with conspicuously reticulate nervules, calyx $5 \mathrm{~mm}$ long, calyx lobes ovate-oblong, drupes with 8 acute ridges, pyrenes with ridges on the abaxial face.

\section{Lasianthus nervosus King \& Gamble}

Lasianthus nervosus King \& Gamble (1904) 129; Ridl. (1923a) 163; K.M.Wong (1989) 367. - Type: Scortechini 342 (holo K; iso BM), Peninsular Malaysia, Perak.

Shrubs to treelets, 1-2 m high; branchlets terete, $1.5-2 \mathrm{~mm}$ diam, densely tomentose. Leaves: blades oblong to oblong- 
Fig. 26 Lasianthus myrtifolius Ridl. subsp. vicarius H.Zhu. a. Habit with inflorescences; b. flower (all: Banying ak Nyudong S.19397, holo L).

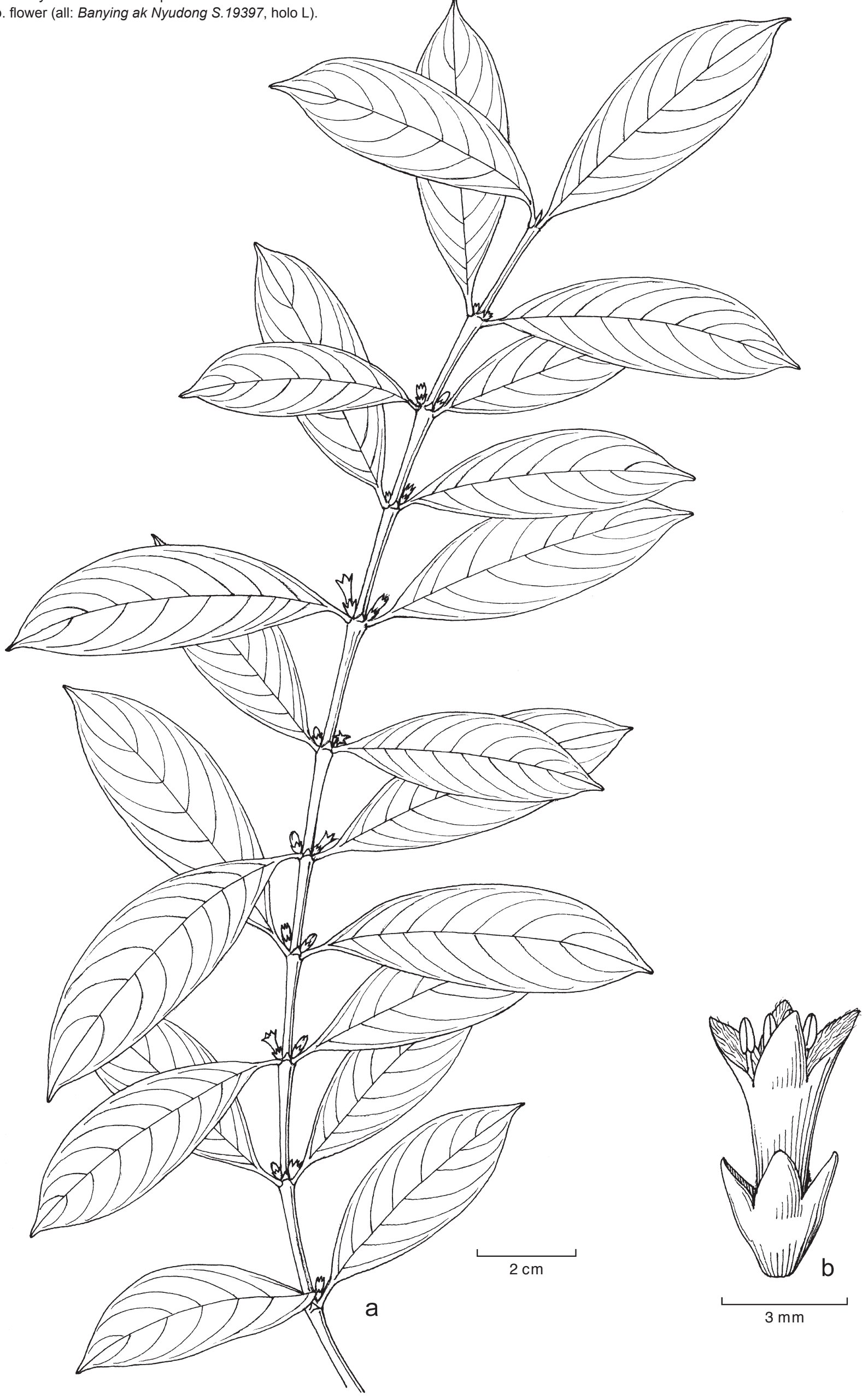


lanceolate, $2.5-5$ by $1-2 \mathrm{~cm}$, coriaceous, glabrous and nitid above, densely tomentose beneath, especially on venation, apex acute, mucronate, margin reflexed, base broadly cuneate to subrounded, midrib depressed above, strongly prominent beneath, nerves flat above, strongly prominent beneath, 6-8 pairs, ascending at an angle of over $50^{\circ}$, curved to the margin, nervules distinct above, prominent beneath, parallel; petioles 3-5 mm long, densely tomentose. Stipules subulate, c. $1 \mathrm{~mm}$ long, densely tomentose. Cymes sessile; bracts absent. Flowers sessile; calyx campanulate, c. $2 \mathrm{~mm}$ long, densely tomentose, lobes 4 , triangular, c. $0.6 \mathrm{~mm}$ long; corolla c. $4 \mathrm{~mm}$ long, tomentose outside, lobes 4 . Drupes globose, sparsely hairy, c. $4 \mathrm{~mm}$ diam; pyrenes 4 .

Distribution - Peninsular Malaysia, Indonesia (Sumatra, Kalimantan).

Notes - This species has densely tomentose hairs on branchlets and leaf midrib and nerves beneath; leaves oblong, 2.5-5 by $1-2 \mathrm{~cm}$ with acute and mucronate apex and abruptly acute base, midrib depressed and nerves flat above, midrib and nerves strongly prominent beneath; cymes sessile, absent; flowers 4-merous; calyx tomentose with 4 triangular teeth; drupes globose with 4 pyrenes.

This species differs from L. myrtifolius by having densely tomentose hairs on branchlets and leaf midrib and nerves beneath; leaves oblong, nerves flat above; dupes globose without conspicuous ridges. Lasianthus myrtifolius has branchlets thinly puberulous or subglabrous; leaves ovate-lanceolate, thinly puberulous or glabrous beneath, with caudate-acuminate apex; nerves conspicuously prominent above; dupes with conspicuous 4 ridges.

\section{Lasianthus nigrescens H.Zhu, sp. nov.}

Proximus L. sabahensis H.Zhu, sed foliorum laminis oblongis apice cuspidatis basi subrotundatis, nervulis conspicue prominentibus, petiolis $5-7 \mathrm{~mm}$ longis et tubis calycis $3 \mathrm{~mm}$ longis differt. - Typus: Beaman 8149 (holo K), Malaysia (Sabah), Ranau District, East Mesilau River, 1950-2100 m alt., in oak-laurel forest, 30 Dec. 1983.

Shrubs, up to $2.5 \mathrm{~m}$ high; branchlets terete, c. $2 \mathrm{~mm}$ diam, glabrous, more or less compressed in the youngest part. Leaves: blades oblong, $6-12$ by $3-5 \mathrm{~cm}$, coriaceous, glabrous, turning black when dry, apex cuspidate, rarely acute, margin reflexed, base subrounded, rarely acute, midrib and nerves prominent on both surfaces, nerves 6-7 pairs, ascending at an angle of $80-90^{\circ}$, curved to the margin, nervules loosely anastomosing, subparallel, conspicuously prominent on both surfaces; petioles 5-7 mm long, glabrous. Stipules triangular, c. $2 \mathrm{~mm}$ long, glabrous. Cymes sessile; bracts absent. Flowers sessile, fascicular; calyx campanulate, tube c. $3 \mathrm{~mm}$ long, with 4 c. $1 \mathrm{~mm}$ long minute teeth, puberulous or glabrous outside; corolla tubular, c. $1 \mathrm{~cm}$ long, puberulous or glabrous outside, lobes 4 , c. $2 \mathrm{~mm}$ long, puberulous or glabrous. Drupes ellipsoid, 6-7 mm long, c. $5 \mathrm{~mm}$ diam, glabrous, crowned by a cupular calyx limb with 4 minute teeth, 2-pyrene, with cork-like structure between pyrenes; pyrenes with a hard wall, smooth on the abaxial face.

Distribution - Endemic to Borneo.

Habitat \& Ecology — In forest between 1800-2200 m altitude. Flowering and fruiting from March to December.

Note - Lasianthus nigrescens is close to L. sabahensis, especially in the same type of drupes that have a cork-like structure between pyrenes. Lasianthus nigrescens differs from the latter in having leaves oblong, with usually cuspidate apex and subrounded base, nervules conspicuously prominent on both surfaces; petioles 5-7 mm long; calyx tube $3 \mathrm{~mm}$ long, not expended at limb. Lasianthus nigrescens differs from L. membranaceus in having coriaceous leaves with nervules conspicu- ously prominent on both surfaces; drupes with cork-like structure between pyrenes; pyrene walls smooth on the abaxial face.

\section{Lasianthus obliquinervis Merr.}

\section{Key to the subspecies}

1. Leaves with acute base; stipules triangular to oblong-triangular. . . . . . . . . . . . . a. subsp. obliquinervis

1. Leaves with cuneate base; stipules linear-subulate b. subsp. novoguineensis

\section{a. subsp. obliquinervis}

Lasianthus obliquinervis Merr. (1906) 136. - Type: Whitford 247 (lecto US, designated here), Philippines, Luzon, Bataan, May 1904.

Shrubs, c. $2 \mathrm{~m}$ high, branches 5-6 mm diam, striate; branchlets $2-3 \mathrm{~mm}$ diam, terete or slightly compressed, puberulous. Leaves: blades ovate-lanceolate to ovate-elliptic, $10-15$ by $2.5-5 \mathrm{~cm}$, subcoriaceous, glabrous above, puberulous beneath, brownish, apex acuminate to acute, rarely cuspidate, base acute, slightly asymmetric and decurrent, midrib slightly depressed above, prominent beneath, pubescent beneath, nerves flat above, prominent beneath, 3-6 pairs, ascending at an angle of $50-70^{\circ}$, curved to the margin, brown pubescent, nervules obscure above, conspicuous beneath, parallel, glabrous; petioles $1.5-2 \mathrm{~cm}$ long, pubescent. Stipules triangular to oblong-triangular, up to 5-6 $\mathrm{mm}$ long, 3-4 $\mathrm{mm}$ broad at base, pubescent. Inflorescences sessile; bracts small, ovate to subulate, c. $1 \mathrm{~mm}$ long, hirsute. Flowers fascicular, sessile; calyx campanulate, 1.5 by $1.5 \mathrm{~mm}$, densely pubescent, limb with 4-5 triangular lobes, lobes $0.5 \mathrm{~mm}$ long, densely hirsute outside, glabrous inside; corolla $6-8 \mathrm{~mm}$ long, densely hirsute except the base, lobes 5, oblong, c. $4 \mathrm{~mm}$ long; stamens 5 , filaments $2 \mathrm{~mm}$ long; anthers $1 \mathrm{~mm}$ long. Drupes globose, hirsute, blue when fresh, $4-5 \mathrm{~mm}$ diam, crowned by persistent calyx lobes, 5-8-ridged, often 6-ridged; pyrenes 5-8, smooth on the abaxial face, triangular in transverse section.

Distribution - Philippines (Luzon to Mindanao), Papua New Guinea (Southern Highlands).

Habitat \& Ecology — Montane forest between 800-1800 m altitude.

Notes - This species is close related to L. chrysoneurus. It differs from the latter by having leaves with longer petioles $(1.5-2 \mathrm{~cm})$ and acute base, as well as less nerves (3-6 pairs); bracts small, less than $2 \mathrm{~mm}$ long; calyx lobes triangular, 1.5 $\mathrm{mm}$ long, glabrous internal surface; drupes conspicuously 5-8-ridged. Lasianthus chrysoneurus has relatively big ovateoblong or oblong leaves with petioles less than $1 \mathrm{~cm}$ long, the base cuneate to obtuse, nerves 8-10 pairs; bracts longer than $2 \mathrm{~mm}$; calyx lobes lanceolate, longer than $1.5 \mathrm{~mm}$, hirsute both surfaces; drupes without conspicuous 5-8 ridges.

Lasianthus obliquinervis is variable in leaf size. Specimens which were treated as $L$. obliquinervis were mixed with $L$. verticillatus even if identified by Merrill himself. From our checking on specimens in L, MO, SING and Chinese herbaria, most specimens indicated as $L$. obliquinervis agree well with L. verticillatus, while some do not. When Merrill described L. obliquinervis, he cited 10 collections (syntypes). We are not sure if all the syntypes represent the same species. Only two syntypes, i.e. Whitfort 247 and Meyer 2212 were traced and seen. Both of them match Merrill's description and surely represent $L$. obliquinervis. Lasianthus obliquinervis differs from L. verticillatus by having stipules oblong-ovate, c. $5 \mathrm{~mm}$ long, calyx limbs with 4-5 triangular lobes and drupes with usually 6 triquetrous pyrenes and not crowned by an enlarged cupular and truncate calyx limb. 


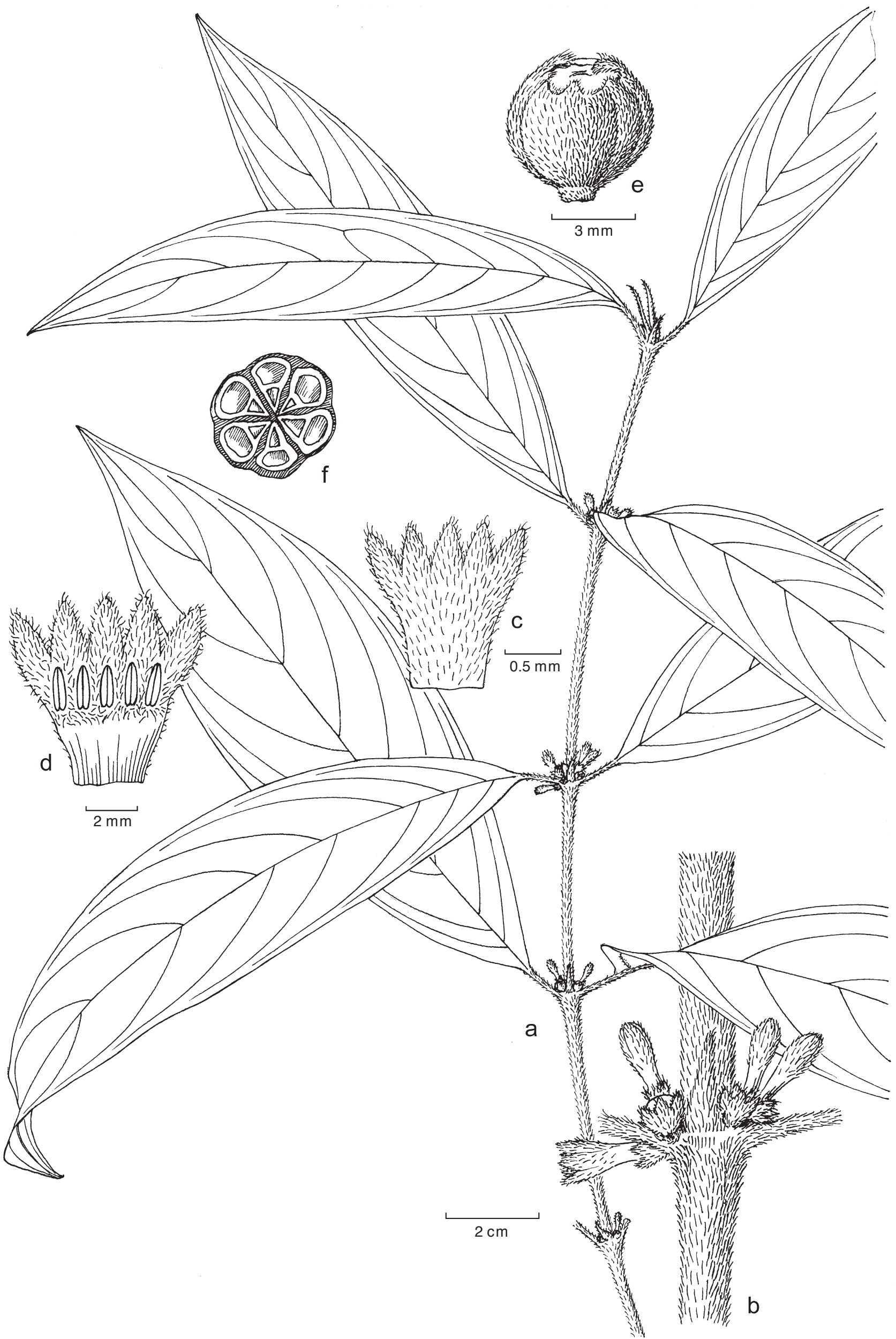

Fig. 27 Lasianthus obliquinervis Merr. subsp. novoguineensis H.Zhu. a. Habit with inflorescences; b. detail of node showing stipule and axillary inflorescences; c. calyx split opened; d. corolla split opened; e. fruit; f. cross section of fruit (all: J. Vandenberg et al. NGF.39936, holo L). 
b. subsp. novoguineensis H.Zhu, subsp. nov. - Fig. 27

A typo foliis basi asymmetrice cuneatis, stipulis lineari-subulatis $6 \mathrm{~mm}$ longis differt. - Typus: J. Vandenberg et al. NGF.39936 (holo L), New Guinea, Western Highlands District, $4450 \mathrm{ft}$ alt., in Castanopsis forest, 30 Oct. 1968.

Shrub, branchlets terete, densely puberulous. Leaves: blades lanceolate to elliptic-lanceolate, $10-15$ by $2.5-5 \mathrm{~cm}$, subcoriaceous, glabrous above, puberulous beneath, apex acuminate, base cuneate and asymmetric, nerves flat above, prominent beneath, 6-7 pairs, pubescent, nervules conspicuous beneath, parallel. Stipules linear-subulate, $6 \mathrm{~mm}$ long, pubescent. Flowers fascicular, sessile; calyx campanulate, densely pubescent, limb with 4-5 triangular lobes; corolla 6-8 mm long, densely hirsute except the base. Drupes globose, hirsute, 4-5 mm diam, crowned by persistent calyx lobes, with 6 obtuse ridges; pyrenes 6 , smooth on the abaxial face, ovate in transverse section.

Distribution - Endemic to Papua New Guinea (Western Highlands).

Habitat \& Ecology — In montane forest between 1400-1500 $\mathrm{m}$ altitude. Flowering and fruiting between July and October.

Additional specimen examined. New Guinea, Western Highlands, Streimann $8460(\mathrm{~L})$

Note - This subspecies differs from the typical subspecies by having leaves with cuneate and asymmetric bases, stipules linear-subulate (6 $\mathrm{mm}$ long). The typical subspecies has leaves with acute and symmetrical bases, stipules triangular to oblongtriangular.

\section{Lasianthus oblongatus Merr}

Lasianthus oblongatus Merr. (1937) 299. - Type: Winkler 1364 (iso NY), W Borneo, Sungei Obat, $100 \mathrm{~m}$ alt.

Shrubs; branchlets terete, c. $2 \mathrm{~mm}$ diam, slightly appressedpubescent. Leaves: blades narrowly oblong, $9-14$ by $2-3 \mathrm{~cm}$, chartaceous, glabrous above, appressed-pubescent hairs on midrib and nerves beneath, apex acuminate, base broadly cuneate to subrounded, midrib and nerves slightly prominent on both surfaces, nerves slender, 13-15 pairs, ascending at an angle of c. $60^{\circ}$, curved to the margin, nervules slightly obscure on both surfaces, subparallel; petioles c. $2 \mathrm{~mm}$ long, pubescent. Stipules lanceolate, 4-5 mm long, hirsute, deciduous. Cymes sessile; bracts with a midrib, leaf-like, oblong-lanceolate, c. 1 $\mathrm{cm}$ long and $2 \mathrm{~mm}$ broad, paired in leaf axil, 4 in each node. Flowers solitary, sessile. Drupes ovoid, c. $4 \mathrm{~mm}$ diam, glabrous or sparsely pubescent, calyx lobes persistent, $1.5-2 \mathrm{~mm}$ long, hirsute; pyrenes 5.

Distribution - Endemic to Borneo.

Note - This species is distinct by rather thin oblong leaves and pairs of persistent lanceolate bracts.

\section{Lasianthus oblongus King \& Gamble}

Lasianthus oblongus King \& Gamble (1904) 127; Ridl. (1923a) 166; K.M.Wong (1989) 368. - Type: King's collector 4128 (lecto SING, selected by Wong 1989; isolecto BM, K, L). Paratypes: Scortechini 265 (n.v.); Ridley 4935 (n.v.), 9702 (n.v.), 9729 (n.v.); Wray 2590 (SING); King's collector 402 (SING), 4462 (K), 10082 (n.v.); Curtis 2081 (SING), Perak. Ridley 7438 (n.v.), Selangor, Peninsular Malaysia.

Shrubs, up to $2 \mathrm{~m}$ high; branchlets terete, c. $2 \mathrm{~mm}$ diam, minutely puberulous or glabrescent, dark when dry. Leaves: blades narrowly oblong-lanceolate, $9-14$ by $2-3 \mathrm{~cm}$, thinly coriaceous, glabrous above, puberulous hairs on midrib and nerves beneath, apex caudate-acuminate, base acute, dark when dry, midrib and nerves slightly prominent above, prominent beneath, nerves $6-7$ pairs, ascending at an angle of $50-60^{\circ}$, curved to the margin; nervules slender, densely anastomosing, parallel; petioles 5-8 $\mathrm{mm}$ long, puberulous. Stipules triangular, c. $3 \mathrm{~mm}$ long, densely pubescent. Cymes sessile, bracts absent. Flowers pediceled; pedicels c. $3 \mathrm{~mm}$ long, glabrous; calyx shallow cupular, c. $1.5 \mathrm{~mm}$ long, glabrous or puberulous, limb c. $1 \mathrm{~mm}$ long, truncate; corolla c. $5 \mathrm{~mm}$ long, pubescent outside, lobes 5 , oblong, densely long-floccose inside. Drupes globose, c. 3-4 $\mathrm{mm}$ diam, puberulous or glabrous, verrucose, with $7-8$ obtuse ridges; pyrenes 7-8.

Distribution - Endemic to Peninsular Malaysia.

Note - Lasianthus oblongus has oblong-lanceolate leaves with clearly parallel nervules, pedicels relatively short, $2-3 \mathrm{~mm}$ long, drupes with 7-8 pyrenes, differing from $L$. purpureus.

\section{Lasianthus obovatibracteatus H.Zhu, sp. nov. - Fig. 28}

Proximus L. inodoro Blume subsp. pubescenti H.Zhu, sed foliis basi asymmetrice rotundatis, stipulis minoribus, bracteis spathulato-obovatis minoribus, lobis calycis 4 et drupis glabris differt. A L. sterophyllo Merr. foliis minoribus basi asymmetrice rotundatis, stipulis minoribus, bracteis spathulato-obovatis et pyrenis 3-4 differt. - Typus: Beaman 10038 (holo L; iso K), Borneo, Sabah, Lahad Datu, 800-880 m alt., in low mossy primary forest, on ultramafic rock soil, 10 June 1984.

Treelet, c. $2.5 \mathrm{~cm}$ high; branchlets terete, c. $2 \mathrm{~mm}$ diam, puberulous, darkish. Leaves: blades ovate-oblong, $5-8$ by $2-3$ $\mathrm{cm}$, thickly coriaceous, glabrous except puberulous midrib beneath, darkish, apex acute, margin slightly recurved, base rounded or subrounded, slightly asymmetric, midrib slightly depressed above, prominent beneath, nerves prominent on both surfaces, $6-7$ pairs, ascending at an angle of $70-80^{\circ}$, curved to the margin, nervules prominent on both surfaces, subreticulate; petioles 5-6 mm long, puberulous. Stipules triangular, $3 \mathrm{~mm}$ long, subglabrous. Inflorescences sessile; bracts 2 , spatulate-obovate, 3 by $2 \mathrm{~mm}$, puberulous or subglabrous. Flowers in fascicle, sessile; calyx campanulate, sparsely puberulous, 4-5 mm long, tubes obconical, 2-2.5 $\mathrm{mm}$ long, lobes 4-5, ovate-triangular, c. $2.5 \mathrm{~mm}$ long; corolla c. $8 \mathrm{~mm}$ long, glabrous outside, lobes 4 , ovate-oblong, c. $3.5 \mathrm{~mm}$ long, $2.5 \mathrm{~mm}$ broad. Drupes ellipsoid, compressed, c. $5 \mathrm{~mm}$ diam, glabrous, crowned by $4-5$ ovate-triangular calyx lobes; pyrenes $3-4$, smooth on the abaxial face.

Distribution - Malaysia (Sabah).

Habitat \& Ecology — Low mossy primary forest on ultramafic rock soil. Flowering and fruiting between March and June.

Note - This species is closely related to L. inodorus subsp. pubescens, but differs from the latter by having leaves with rounded and slightly asymmetric base, relatively small stipules, bracts relatively small and spatulate-obovate, drupes glabrous with 3-4 pyrenes. Lasianthus inodorus subsp. pubescens has leaves with cuneate or acute base, stipules $4 \mathrm{~mm}$ long, densely pubescent, bracts orbicular and densely pubescent, up to $5 \mathrm{~mm}$ diam, calyx lobes 5 , drupes pubescent. Lasianthus obovatibracteatus is also similar to $L$. sterrophyllus, but differs from the latter by having relatively small leaves with rounded and slightly asymmetric base, relatively small stipules, bracts spatulate-obovate, drupes with 3-4 pyrenes. Lasianthus sterrophyllus has leaves $9-12 \mathrm{~cm}$ long with acute to subacute base, bracts absent, stipules $4-5 \mathrm{~mm}$ long, drupes with 5 pyrenes.

\section{Lasianthus obscurus (Blume ex DC.) Miq. - Map 3}

Lasianthus obscurus (Blume ex DC.) Miq. (1857) 317; (1869) 245, p.p. excl. specimen Zollinger 621; Hook.f. (1880) 183; Bakh.f. (1965) 341; H.Zhu (2002) 80. - Mephitidia obscura Blume ex DC. (1830) 453. - Type: Blume s.n. (holo L, barcode L0057529), Java.

Lasianthus kurzii Hook.f. var. sylvicola H.S.Lo (1993) 3; H.Zhu (1998) 153 H.S.Lo (1999) 90. - Type: E. Hainan Expedit. 530 (holo SCBI), China, Hainan.

Lasianthus kurzii Hook.f. var. fulvus C.Y.Wu \& H.Zhu (in Zhu 1994) 60. - Type: Yunnan-expedit. 59-13346 (holo KUN), China, Yunnan, Xishuangbanna. 


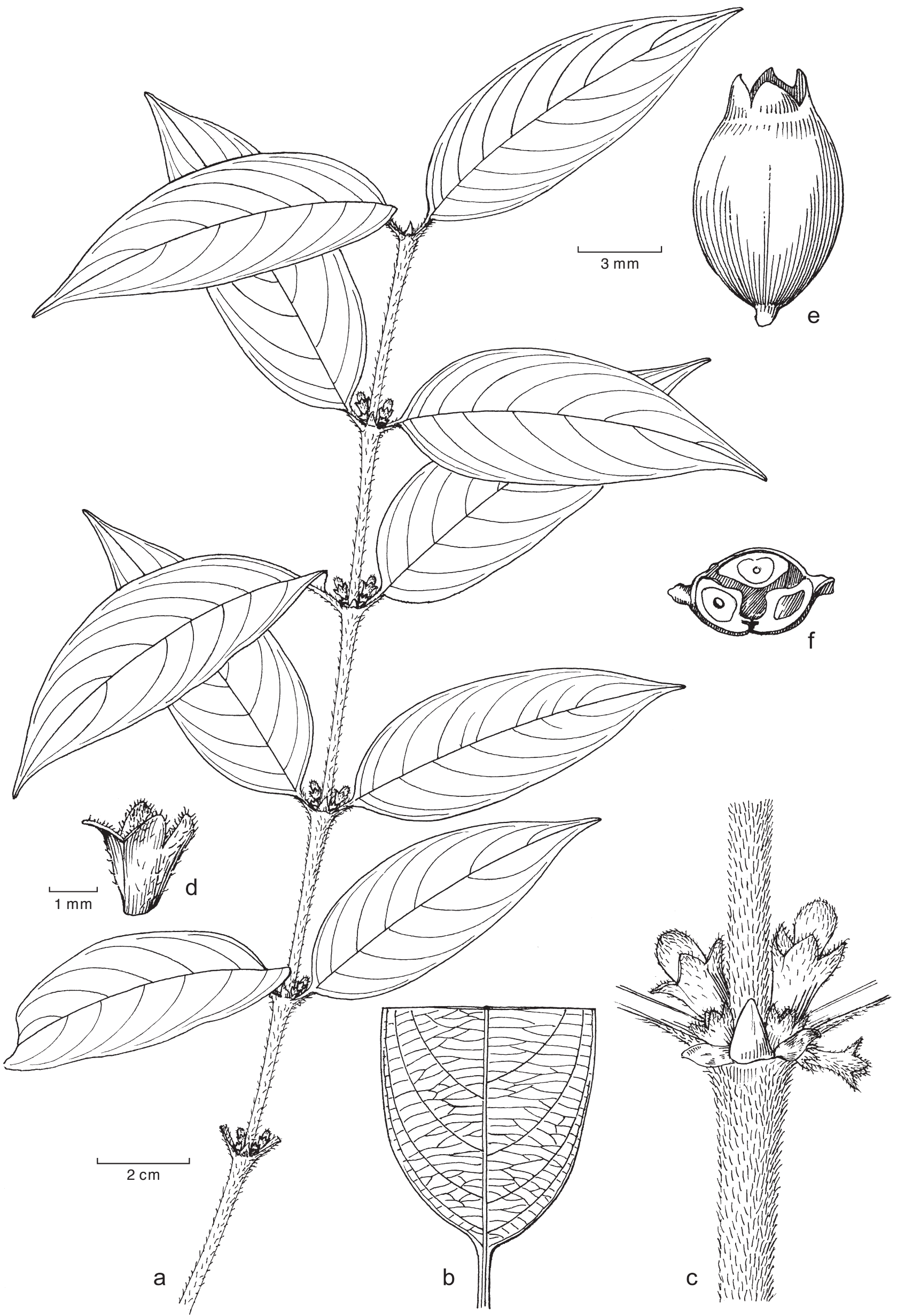

Fig. 28 Lasianthus obovatibracteatus H.Zhu. a. Habit with inflorescences; b. detail of lower surface of leaf showing subreticulate nervules; c. detail of node showing stipule and axillary inflorescences; d. calyx; e. fruit; f. cross section of fruit (all: J.H. Beaman 10038, holo L). 


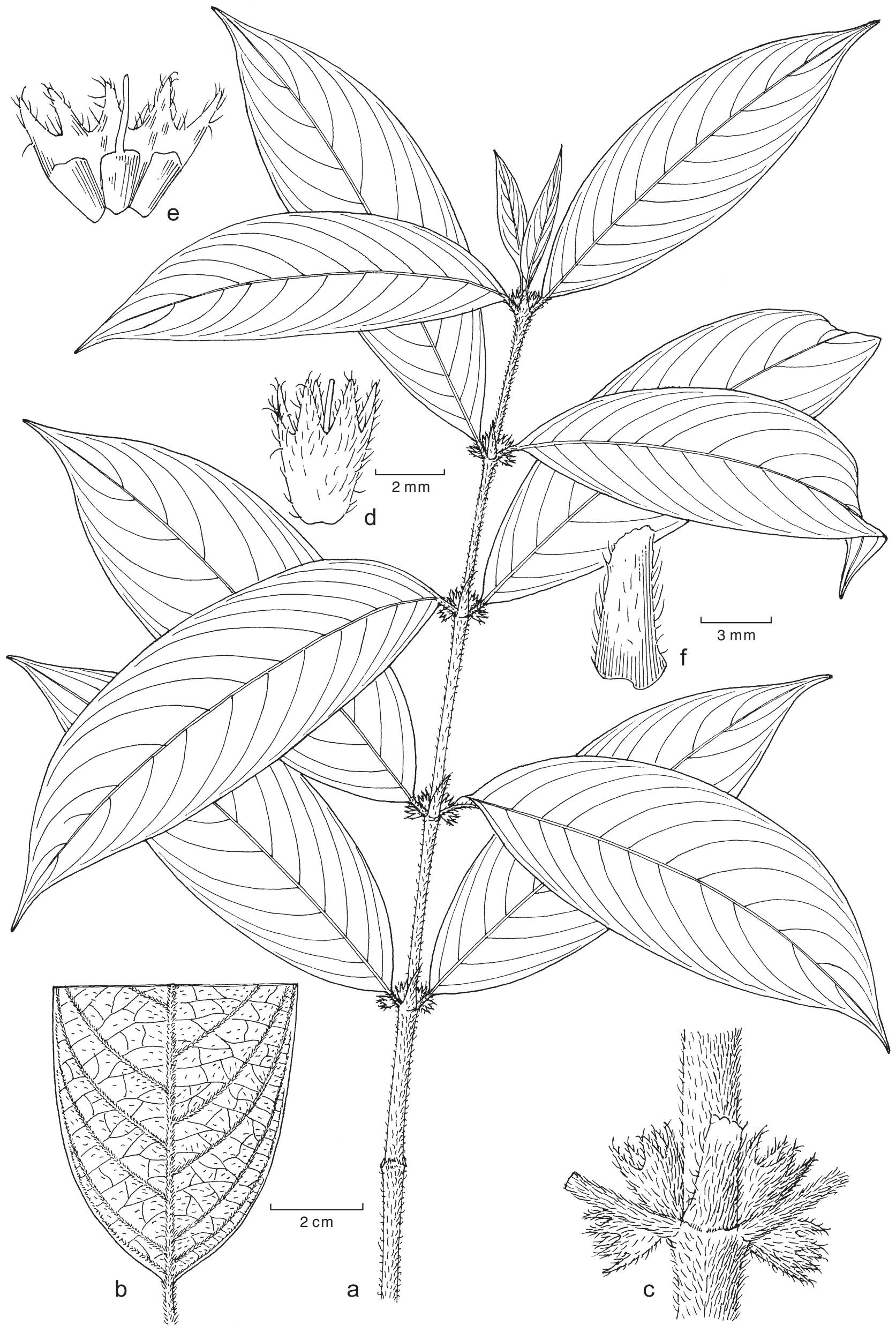

Fig. 29 Lasianthus palawanensis H.Zhu. a. Habit with inflorescences; b. detail of lower surface of leaf showing reticulate nervules; c. detail of node showing stipule and axillary inflorescences; d. calyx; e. calyx split opened; f. stipule (all: A.D.E. Elmer 13252, holo L). 
Shrubs, to $3 \mathrm{~m}$ high; branchlets terete, robust, c. $3 \mathrm{~mm}$ diam, densely spreading tomentose. Leaves: blades elliptic-oblong to oblong, $12-20$ by $3-5 \mathrm{~cm}$, membranaceous, or thinly coriaceous, glabrous above except sometimes tomentose hairs on midrib, tomentose beneath, apex acuminate to cuspidate-acute, base cuneate to subrounded, midrib and nerves slightly prominent above, prominent beneath, nerves $7-10$ pairs, ascending at an angle of $50-60^{\circ}$, curved to the margin, nervules distinct on both surfaces, parallel; petioles $5-10 \mathrm{~mm}$ long, spreading tomentose. Stipules triangular or oblong-lanceolate, up to $8 \mathrm{~mm}$ long, tomentose. Cymes sessile; bracts persistent, outer bracts ovate, inner bracts lanceolate, all not more than $5 \mathrm{~mm}$ long, densely tomentose. Flowers sessile or subsessile, numerous; calyx campanulate, $2-3 \mathrm{~mm}$ long, tomentose, lobes triangular, $4-6$, c. $1-1.5 \mathrm{~mm}$ long; corolla $5-6 \mathrm{~mm}$ long, puberulous outside in the upper half, pubescent inside at the throat. Drupes subglobose, 4-6 mm diam, tomentose, crowned by persistent calyx lobes; pyrenes 5-6.

Distribution - China (Yunnan, Hainan), Vietnam, Thailand, Indonesia (Java, Sulawesi).

Notes - Lasianthus obscurus is very close to L. chrysoneurus. Lasianthus obscurus has densely spreading tomentose hairs on branches, leaf undersides, stipules, bracts, and calyx, while $L$. chrysoneurus has appressed pubescence on branches, leaf undersides, stipules, bracts, and calyx. They are separated only by different indumentum. Considering that there are relatively few diagnostic characters in the genus and the clear distinction between the two taxa by different types of indumentum, it seems better to treat them as two separate species.

Lasianthus kurzii var. sylvicola and var. fulvus from mainland SE Asia are conspecific with L. obscurus, and L. kurzii var. kurzii from India and mainland SE Asia is conspecific with L. chrysoneurus.

\section{Lasianthus palawanensis H.Zhu, sp. nov. - Fig. 29}

Proximus L. trichophlebus Hemsl., sed foliis obovato-oblongis chartaceis, nervulis subreticulatis, lobis calycis 5 subulato-lanceolatis aequalis tubo differt. — Typus: Elmer 13252 (holo L), Philippines, Palawan Island, May 1911.

Shrub; branchlets terete, robust, c. $2.5-3 \mathrm{~mm}$ diam, sparsely hirsute, densely at nodes, dark-brownish. Leaves: blades obovate-oblong, $10-12$ by $3-3.5 \mathrm{~cm}$, chartaceous, glabrous and dark-brownish above, puberulous or glabrescent and lightly brownish beneath, apex cuspidate or shortly caudate, mucronate, base acute; midrib flat above, prominent and sparsely hirsute beneath, nerves slightly prominent above, prominent and hirsute beneath, c. 11 pairs, ascending at an angle of c. $60^{\circ}$, curved gradually to margin, nervules slightly prominent on both surfaces, obscure beneath, reticulate; petioles 3-5 $\mathrm{mm}$ long, hirsute. Stipules triangular-lanceolate, $6-7 \mathrm{~mm}$ long, hirsute. Inflorescences sessile, bracts fewer, linear, c. $2 \mathrm{~mm}$ long, hirsute. Flowers fascicular, sessile; calyx campanulate, c. $4 \mathrm{~mm}$ long, hirsute, lobes 5 , subulate-lanceolate, c. $2 \mathrm{~mm}$ long; corolla c. 5-6 mm long, tube glabrous outside, lobes 5, lanceolate, c. $2 \mathrm{~mm}$ long, puberulous external surface; ovary with 5 locules. Drupes not seen.

Distribution - Endemic to Palawan Islands of Philippines.

Note - This species has hirsute hairs on nodes of branchlets, leaf nerves beneath, stipules, and calyx; stipules triangular-lanceolate, 6-7 $\mathrm{mm}$ long. It seems closely related to L. trichophlebus, but differs from the latter by having obovateoblong and chartaceous leaves with subreticulate nervules, calyx lobes 5 , subulate-lanceolate, as long as calyx tube. Lasianthus trichophlebus has oblong and coriaceous leaves with parallel nervules, calyx lobes 4 , triangular, shorter than calyx tube.

\section{Lasianthus papuanus Wernham}

Lasianthus papuanus Wernham (1916) 78; Valeton (1927) 109; Merr. \& L.M.Perry (1946) 219. - Type: Kloss s.n. (holo BM), New Guinea, 500 ft.

Shrubs; branchlets terete, densely appressed flavi-hirsute. Leaves: blades oblong-lanceolate, $7-11$ by $2-3 \mathrm{~cm}$, glabrous above except hairy midrib, appressed-pubescent hairs on venation beneath, apex acute, base broadly cuneate to subrounded, nerves slightly obscure above, prominent beneath, 7-8 pairs, nervules obscure above, subreticulate; petioles 4-5 $\mathrm{mm}$ long, densely flavi-pubescent. Stipules subulate, $8 \mathrm{~mm}$ long, appressed-pubescent, deciduous. Cymes sessile; bracts absent. Flowers solitary or paired, 5-merous; calyx campanulate, lobes triangular-lanceolate, $2.5 \mathrm{~mm}$ long, glabrous inside and pilose outside; corolla tube $4.8 \mathrm{~mm}$ long, sparsely hirsute, lobes 5 , oblong, c. $1.5 \mathrm{~mm}$ long, hirsute outside, barbate inside. Fruits not seen.

\section{Distribution - New Guinea.}

Note - This species is very close to $L$. chrysotrichus, but differs from the latter by having appressed-pubescence on branches, nerves beneath, stipules up to $8 \mathrm{~mm}$ long, 5-merous flowers without bracts, and triangular-lanceolate calyx lobes, while L. chrysotrichus has spreading harsh-hirsute hairs, stipules 2-3 mm long, usually 4-merous flowers with linear bracts and lanceolate calyx lobes. It differs from $L$. hexandrus by having stipules up to $8 \mathrm{~mm}$ long, calyx campanulate, lobes triangular-lanceolate.

\section{Lasianthus pedicellatus H.Zhu, sp. nov. - Fig. 30}

Proximus L. oblongo King \& Gamble, sed stipulis minoribus, calycibus triangulatis dentatis, drupis levigatis obtuse 4-5-porcatis, pyrenis 4-5 differt. — Typus: De Vogel 5344 (holo L), Sulawesi, Palu, Mt Poroka Timbu, 1950 $\mathrm{m}$ alt., in primary montane forest, 14 May 1979.

Treelet, $2 \mathrm{~m}$ high; branchlets terete, c. $1.5 \mathrm{~mm}$ diam, dark in the youngest part, glabrous or thinly puberulous. Leaves: blades lanceolate, $6-9$ by $1.5-2.5 \mathrm{~cm}$, glabrous except sparsely puberulous midrib and nerves beneath, apex acuminate to caudate, aristate, arista c. $1 \mathrm{~mm}$ long, margin recurved, base acute, midrib slightly depressed above, prominent beneath, nerves flat above, prominent beneath, 5 pairs, ascending at an angle of c. $60^{\circ}$; nervules prominent on both surfaces, parallel; petioles c. $5 \mathrm{~mm}$ long, sparsely puberulous or glabrescent. Stipules very small, triangular, less than $1 \mathrm{~mm}$ long. Inflorescences extremely congested to nearly sessile; bracts absent. Flowers fascicular, pediceled; pedicels slender, c. $2 \mathrm{~mm}$ long; calyx obconical, c. 1 $\mathrm{mm}$ long, with 5 triangular teeth, puberulous; corolla c. $4 \mathrm{~mm}$ long, puberulous outside. Drupes subglobose, c. $3 \mathrm{~mm}$ diam, smooth, subglabrous, with $4-5$ obtuse ridges; pyrenes $4-5$, smooth on the abaxial face, orbicular at the transverse section.

Distribution - Malaysia (Sabah) and Indonesia (Sulawesi).

Habitat \& Ecology — In montane forest between 1500-2000 $\mathrm{m}$ altitude. Flowering and fruiting between March and May.

Additional specimens examined. Sulawesi, Mt Roroka Timbu, E.F. de Vogel 5136 (K, L); Borneo, Sabah, J.H. Beaman 8928 (K, L); Sabah, Kinabalu, J \& M.S. Clemens 29838 (L)

Note - This species is closely related to $L$. oblongus, but differs from the latter by having very small stipules, calyx with triangular teeth, drupes smooth, with 4-5 obtuse ridges and crowned by small triangular calyx teeth, pyrenes $4-5$. Lasianthus oblongus has relatively big stipules 3-4 mm long, calyx shallow cupular with truncate limb, drupes verrucose, with 7-8 obtuse ridges and crowned by a short cupular calyx limb, pyrenes 7-8. 


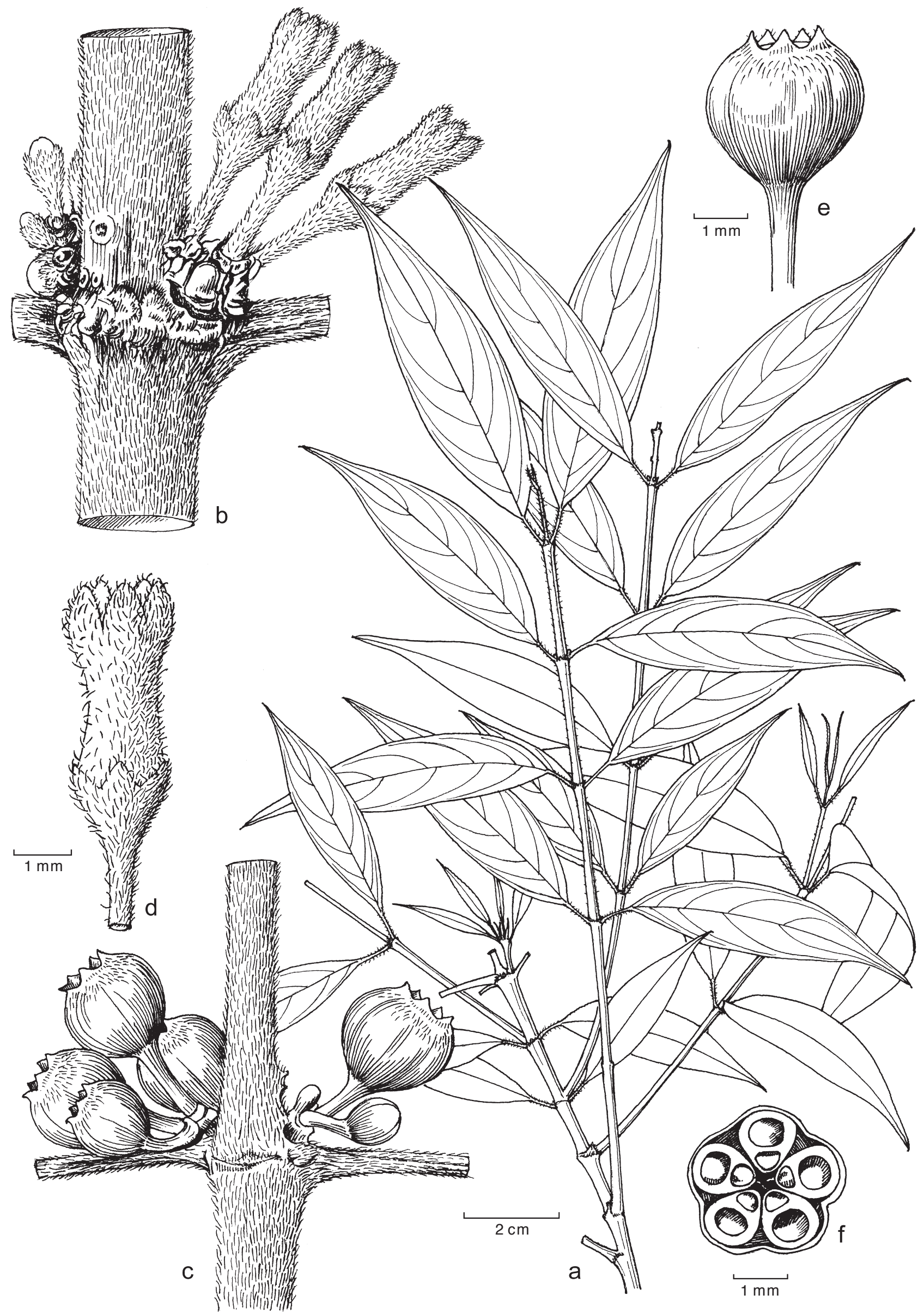

Fig. 30 Lasianthus pedicellatus H.Zhu. a. Habit; b. detail of node showing axillary inflorescences; c. detail of node showing fruits; d. flower; e. fruit; f. cross section of fruit (all: E.F. de Vogel 5344, holo L). 


\section{Lasianthus pendulus Ridl.}

Lasianthus pendulus Ridl. (1909) 37; (1923a) 168; K.M.Wong (1989) 372 - Lasianthus capitatus Blume subsp. pendulus (Ridl.) H.Zhu (2000b) 398. — Type: Ridley 14007 (holo SING; iso K), Peninsular Malaysia, Pahang, Telem.

Treelets, c. $2 \mathrm{~m}$ high; branchlets terete, robust, c. $3 \mathrm{~mm}$ diam, densely spreading long-hairy. Leaves: blades ovate-lanceolate, $7-11$ by $2-3.5 \mathrm{~cm}$, coriaceous, glabrous above, spreading longhairy beneath, apex acuminate, margin conspicuously reflexed, base rounded to subcordate, midrib and nerves conspicuously depressed above, strongly prominent beneath, nerves 8-9 pairs, ascending at an angle of over $50^{\circ}$, curved to the margin, nervules slightly obscure, distinct beneath, subparallel; petioles very short, c. $1 \mathrm{~mm}$ long, densely long-hairy. Stipules inconspicuous. Cymes pedunculate; peduncles $2-3.5 \mathrm{~cm}$ long, densely spreading long-hairy; bracts filiform, numerous, up to $1.5 \mathrm{~cm}$ long, densely long-hairy. Flowers sessile; calyx with 5 long, lanceolate-subulate and hairy lobes; corolla glabrous. Drupes obovoid, narrowed to base, 5-ridged, crowned by hairy calyx lobes; pyrenes 5 .

Distribution - Peninsular Malaysia.

Habitat \& Ecology — Montane forest, 1500-1900 m altitude.

Note - Lasianthus pendulus differs from L. capitatus in having ovate to ovate-lanceolate leaves with rounded base, shorter petioles, nerves conspicuously depressed above and more slender peduncles.

\section{Lasianthus perakensis King \& Gamble}

\section{Key to the varieties}

1. Leaves with nerves $7-8$ pairs, $15-25$ by $5.5-8 \mathrm{~cm}$; rustypuberulous on branches, midrib and nerves beneath; drupes c. $4 \mathrm{~mm}$ diam, sessile . . . . . . . . . a. var. perakensis

1. Leaves smaller with nerves $3-5$ pairs, $13-16$ by $3-4.5 \mathrm{~cm}$; sparse puberulous on branches, midrib and nerves beneath; drupes smaller c. $2 \mathrm{~mm}$ diam, with $1 \mathrm{~mm}$ long pedicels .. $\ldots \ldots \ldots \ldots \ldots \ldots$ b. var. kalimantanensis

\section{a. var. perakensis}

Lasianthus perakensis King \& Gamble (1904) 126; Ridl. (1923a) 160; K.M Wong (1989) 372 (excl. syn. L. flavinervius Ridl.); H.Zhu (2001b) 139. Type: Wray 4128 (lecto SING, designated by Wong 1989). Paratypes: King's collector 682 (n.v.), 2438 (n.v.), 2838 (n.v.), 10210 (n.v.), Peninsular Malaysia, Perak.

Shrubs; branches terete, robust, c. $3 \mathrm{~mm}$ diam, or slightly compressed in the youngest part, minutely rusty-puberulous. Leaves: blades elliptic or obovate-elliptic, $15-25$ by $5.5-8$ $\mathrm{cm}$, subcoriaceous, glabrous above, puberulous on midrib and nerves beneath, apex cuspidate or caudate, base cuneate; midrib slightly depressed above, prominent beneath, nerves 7-8 pairs, flat above, prominent beneath, nervules subparallel, conspicuous on both sides; petioles about $1 \mathrm{~cm}$ long, rusty-puberulous. Stipules triangular, acute, up to $5 \mathrm{~mm}$ long, rusty-puberulous. Cymes sessile, bracts absent. Flowers sessile, crowned; calyx campanulate, c. $2 \mathrm{~mm}$ long, much tapered to the base, mouth wide, truncate, with 5 indistinct blunt spreading segments, pubescent; corolla short, $3 \mathrm{~mm}$ long, lobes ovate-triangular, $1.5 \mathrm{~mm}$ long, pubescent; ovary 5-celled. Drupes hemispheric, c. $4 \mathrm{~mm}$ diam, subglabrous or sparsely puberulous, 10-ribbed, crowned by the calyx limb; pyrenes 10.

Distribution - S Thailand, Malaysia (Peninsular, Sabah) and Indonesia (Sumatra, Kalimantan).
Note - Lasianthus perakensis has a wide to slightly trumpetshaped calyx limb with 5 indistinct blunt spreading lobes, drupes hemispheric with 10 obtuse ridges and crowned by blunt calyx lobes, pyrenes 5 .

\section{b. var. kalimantanensis H.Zhu, var. nov.}

A typo foliis minoribus, nervis $3-5$, ramis sparsim puberscentibus, costis et nervis sparsim puberscentibus subter, pedicellis $1 \mathrm{~mm}$ longis, drupis minoribus differt. - Typus: Church et al. 713 (holo K), Borneo, C Kalimantan, Sintang, $100 \mathrm{~m}$ alt.

Branches sparse puberulous. Leaves: blades elliptic or obovateelliptic, $13-16$ by $3-4.5 \mathrm{~cm}$, subcoriaceous, glabrous above, sparse puberulous on midrib and nerves beneath, apex cuspidate or caudate, base broadly cuneate; nerves 3-5 pairs, flat above, prominent beneath, nervules subparallel, conspicuous on both sides. Stipules triangular, acute, up to $4-5 \mathrm{~mm}$ long, puberulous. Cymes sessile, bracts absent. Flowers with $1 \mathrm{~mm}$ long pedicels, crowned; calyx campanulate, calyx mouth wide, truncate, with 5 indistinct teeth, pubescent. Drupes hemispheric, c. $2 \mathrm{~mm}$ diam, subglabrous or sparsely puberulous, 10-ribbed, crowned by the calyx limb; pyrenes 10 .

Habitat - Mixed dipterocarp forest

Distribution - Borneo, C Kalimantan.

Note - The variety differs from the typical variety by having smaller leaves with nerves $3-5$ pairs, $13-16$ by $3-4.5 \mathrm{~cm}$; sparse puberulous on branches, midrib and nerves beneath; smaller drupes c. $2 \mathrm{~mm}$ diam, with $1 \mathrm{~mm}$ long pedicels.

\section{Lasianthus pergamaceus King \& Gamble}

Lasianthus pergamaceus King \& Gamble (1904) 123; Ridl. (1923a) 164; K.M. Wong (1989) 369, p.p. - Type: Wray 270 (holo SING; iso K), Peninsular Malaysia, Perak, $4500 \mathrm{ft}$.

Lasianthus coriaceus King \& Gamble (1904) 123. — Lectotype (designated by Wong 1989): Scortechini 332 (lecto SING; isolecto K), Perak; Ridley 10217 (para, n.v.), Peninsular Malaysia, Selangor.

Lasianthus crassifolius Ridl. (1918) 85; (1923a) 165. — Lectotype (designated here): Ridley 15689 (lecto K), Peninsular Malaysia; Selangor; Maingay s.n. (para, n.v.), Peninsular Malaysia.

Treelets; branchlets terete, robust, glabrous or minutely puberulous in the youngest part, sulcate when dry. Leaves: blades oblong-elliptic, $18-25$ by $5-8 \mathrm{~cm}$, thinly coriaceous, glabrous on both surfaces except minutely puberulous in young leaves beneath, apex cuspidate-acuminate, base broadly cuneate to subrounded, slightly asymmetric, midrib and nerves distinct or slightly depressed above, strongly prominent beneath, nerves $10-12$ pairs, ascending at an angle of over $70^{\circ}$, curved to the margin, secondary nerves from the costa between nerves conspicuous, nervules distinct on both surfaces and prominent beneath, reticulate; petioles $7-10 \mathrm{~mm}$ long. Stipules triangular, 3-4 mm long, glabrous. Cymes shortly pedunculate; peduncles robust, 2-3 mm long, glabrous; bracts inconspicuous. Flowers sessile; calyx obconic-cupular, 3-5 mm long, with a truncate or minutely 4-toothed limb, glabrous; corolla tubular, pubescent outside, villous inside, 4-toothed; anthers 4. Drupes cupularglobose, c. 5-6 mm diam, glabrous or minutely hairy, crowned by a truncate or minutely 4-toothed limb; pyrenes 4 .

Distribution - Peninsular Malaysia, Philippines (Palawan).

Note - This species is closely related to $L$. chinensis and $L$. repoeuensis, but it differs from both in having short robust peduncles and usually sulcate branchlets and cupulate calyx with truncate limb and drupe with 4 pyrenes. It is also similar to L. subaureus, but differs from the latter by having large leaves, sulcate branchlets, and peduncled cymes. 


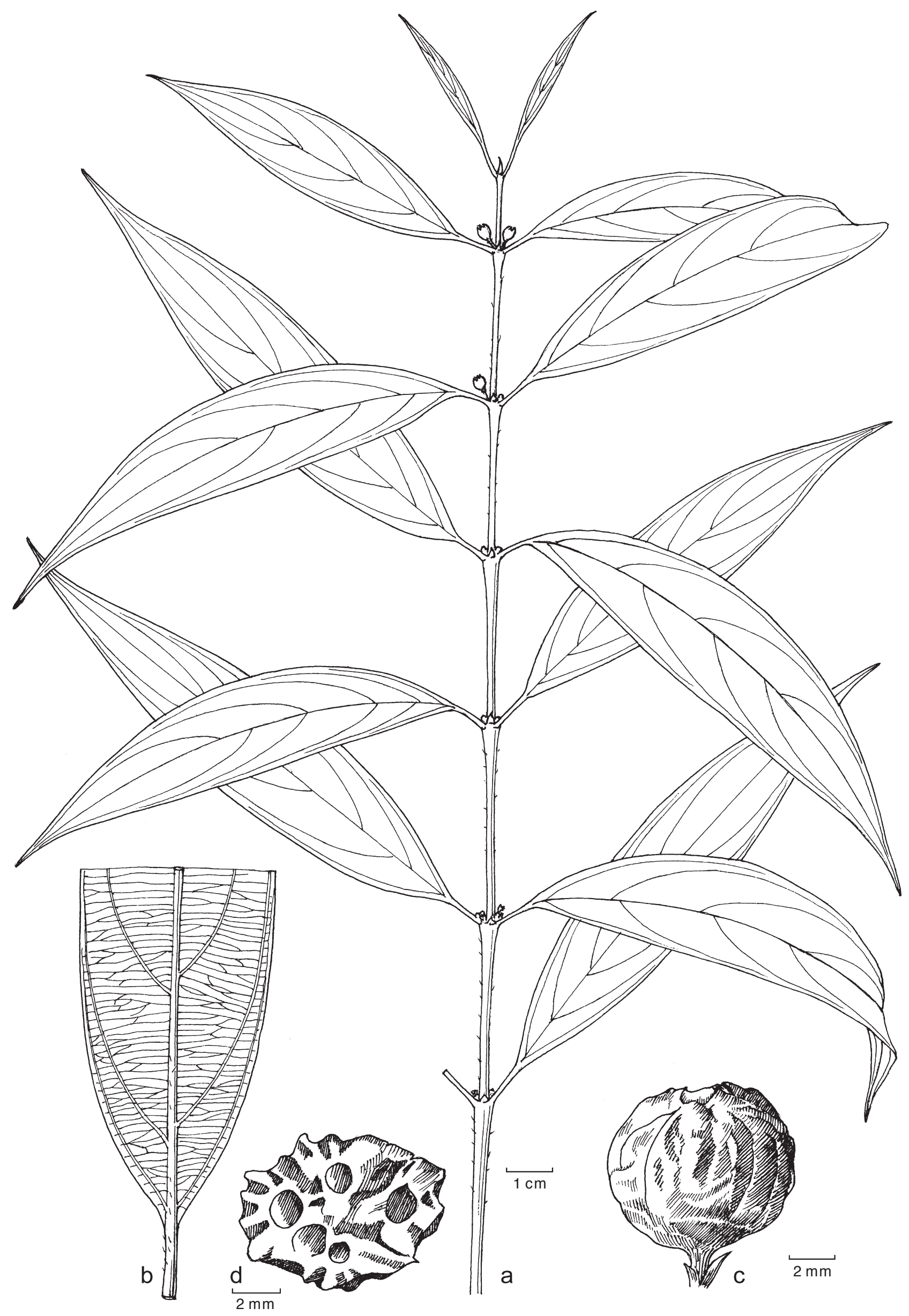

Fig. 31 Lasianthus phymatodeus H.Zhu. a. Habit; b. lower surface of leaf showing parallel nervules; c. fruit; d. cross section of fruit (all S. Tong S.33878, holo L). 


\section{Lasianthus phymatodeus H.Zhu, sp. nov. - Fig. 31}

Proximus L. kinabaluensis Stapf, sed foliis non brochidodromis, nervulis densis parallelis, drupis conspicue verrucosis, pyrenis 4 conspicue acute porcatis differt. - Typus: Tong S.33878 (holo L; iso K), Sarawak, Lubok Antu, $3300 \mathrm{ft}$ alt., in mossy forest, 13 Mar. 1974.

Treelet, c. $4 \mathrm{~m}$ high; branchlets terete, slightly compressed in the youngest part, c. $1.5 \mathrm{~mm}$ diam, glabrous, brownish. Leaves: blades lanceolate to ovate-elliptic, $8-12$ by $2-3.5 \mathrm{~cm}$, coriaceous, glabrous on both surfaces, apex acuminate to slightly caudate, base acute to abruptly acute, midrib flat to slightly depressed above, prominent beneath, glabrous; nerves flat above, prominent beneath, 4-5 pairs, ascending at an angle of $50-60^{\circ}$, curved to margin, glabrous, nervules obscure above, conspicuous beneath, dense and parallel, glabrous; petioles 6-8 mm long, glabrous. Stipules triangular, 1.5-2 mm long, puberulous, bristle at the internal base of stipules. Inflorescences sessile to subsessile; bracts inconspicuous. Flowers small; calyx campanulate, c. $1 \mathrm{~mm}$ long, sparsely puberulous or glabrous, with 4 minutely subulate teeth; corolla not seen. Drupes oblate-globose, c. 6-7 mm diam, glabrous, strongly warty; pyrenes 4 , with irregular sharp ridges on all sides from transverse section view.

Distribution - Borneo (Sarawak, Lubok Antu district).

Habitat \& Ecology — In mossy forest between 3300-4200 $\mathrm{ft}$ altitude. Flowering and fruiting in March.

Additional specimen examined. Sarawak, Lubok Antu district, Paul Chai S. $33826(\mathrm{~K}, \mathrm{~L})$

Note - This species is closely related to L. kinabaluensis, but differs from the latter by having leaves with dense and parallel nervules, without looped venation, drupes strongly warty and with 4 pyrenes, pyrenes with conspicuously irregular sharp ridges on all sides from cross section view. Lasianthus kinabaluensis has leaves with looped venation, nervules loose and reticulate, drupes slightly warty, usually with 3 pyrenes, pyrenes slightly warty from cross section view.

\section{Lasianthus pilosus Wight}

\section{Key to the varieties}

1. Leaves $3.5-6 \mathrm{~cm}$ broad $\ldots \ldots \ldots \ldots \ldots$ a. var. pilosus

1. Leaves relatively narrow, $2.5-3 \mathrm{~cm}$ broad .......... $\ldots \ldots \ldots \ldots \ldots \ldots \ldots$. var. angustifolius

\section{a. var. pilosus}

Lasianthus pilosus Wight (1846) 506; Hook.f. (1880) 182; King \& Gamble (1904) 115; Ridl. (1923a) 157; K.M.Wong (1989) 370; H.Zhu (2001b) 139. - Type: Kew Dist. 869 (Griffith s.n.) (holo K), Peninsular Malaysia.

Lasianthus retosus Wight (1846) 506; Hook.f. (1880) 181. — Lasianthus pilosus Wight var. retosus (Wight) Ridl. (1923a) 157. - Type: Kew Dist. 2918 (Griffith s.n.) (holo K), Peninsular Malaysia, Mt Ophir.

Lasianthus pilosus Wight var. glabra King \& Gamble (1904) 115. — Type: Ridley 7424 (n.v.), Peninsular Malaysia, Selangor.

Lasianthus robustus King \& Gamble (1904) 123; Ridl. (1923a) 165. — Type: Hervey s.n. (Ridley s.n. in protologue) (holo SING), Peninsular Malaysia.

Shrubs or treelets, up to $3 \mathrm{~m}$ high; branchlets terete, c. $2 \mathrm{~mm}$ diam, densely spreading pilose. Leaves: blades oblong, ellipticoblong or oblong-lanceolate, $8-17$ by $3.5-6 \mathrm{~cm}$, chartaceous to subcoriaceous, pilose both surfaces, denser on midrib above and midrib and nerves beneath, apex caudate-acuminate, base rounded to slightly subcordate, asymmetric, nerves slender, flat or slightly depressed above, prominent beneath, 9-15 pairs, nervules obscure above, distinct beneath, reticulate; petioles 3-5 mm long, densely pilose. Stipules triangular-lanceolate, acute, densely pilose, up to $3 \mathrm{~mm}$ long. Cymes sessile; bracts small, filiform, 4-5 mm long, pilose. Flowers sessile; calyx dense pilose, tubular, up to $8 \mathrm{~mm}$ long, lobes $5-7$, lanceolate to linear, up to $5 \mathrm{~mm}$ long; corolla tubular, up to $15 \mathrm{~mm}$ long, pilose outside, lobes 5-7, linear-lanceolate, $3 \mathrm{~mm}$ long. Drupes subglobose, sparsely pilose or glabrous crowned by long hairy calyx limbs with long lobes; pyrenes 5-7, very hard.

Distribution — S Thailand, Malaysia (Peninsular, Sarawak).

\section{b. var. angustifolius Hook.f.}

Lasianthus pilosus Wight var. angustifolius Hook.f. (1880) 182; King \& Gamble (1904) 115; Ridl. (1923a) 157; Craib (1934) 215; K.M.Wong (1989) 372; H.Zhu (2001b) 139. - Type: Griffith s.n. (holo K), Burma, Tenasserim, Mergui.

\section{Distribution — Burma, Thailand, Peninsular Malaysia.}

Note - Differing from typical variety by leaves relatively narrow, $10-12.5$ by $2.5-3 \mathrm{~cm}$.

\section{Lasianthus politus Ridl.}

Lasianthus politus Ridl. (1918) 85; (1923a) 158; K.M.Wong (1989) 372; H.Zhu (2001b) 139. - Type: Ridley 15690 (holo K), Peninsular Malaysia, Selangor.

Shrubs, c. $2 \mathrm{~m}$ high; branchlets terete, c. $2 \mathrm{~mm}$ diam, densely tomentose. Leaves: blades lanceolate, $6-12$ by $2-3 \mathrm{~cm}$, coriaceous, shining green and glabrous above, tomentose beneath, apex acuminate, margin reflexed, base shortly cuneate or acute, midrib depressed above, strongly prominent beneath, nerves flat or slightly depressed above, strongly prominent beneath, $6-8$ pairs, ascending at an angle of $50-60^{\circ}$, curved to the margin, nervules slightly prominent above, prominent beneath, reticulate; petioles $2-3 \mathrm{~mm}$ long, densely tomentose. Stipules narrowly lanceolate, c. $2 \mathrm{~mm}$ long, densely tomentose. Cymes sessile; bracts linear, numerous, long-hairy. Flowers sessile; calyx very densely hairy, 3-4 $\mathrm{mm}$ long, tube short, lobes 5 , lanceolate to linear, acuminate, 2-2.5 mm long, densely long hairy. Drupes globose, hairy, crowned by 5 hairy calyx lobes; pyrenes 5.

Distribution — Thailand, Peninsular Malaysia.

Note - This species has leaves coriaceous, glabrous above, densely tomentose beneath, lanceolate, cuneate at base, midrib depressed above and elevated beneath, nervules reticulate; bracts small, linear, hirsute, less than $5 \mathrm{~mm}$ long; drupes densely hirsute.

\section{Lasianthus pseudolongifolius H.Zhu, sp. nov. - Fig. 32}

Similis L. longifolio Wight, sed stipulis minoribus, lobis calycis $4-5$, oblongis, 4-5 mm longis, $2.5 \mathrm{~mm}$ latis, tubo calycis $3 \mathrm{~mm}$ longo differt. - Typus: Bernard Lee S.39988 (holo L), Borneo, Sarawak, Sg. Nawai, 800 m alt., on sandstone soil, 5 Sept. 1978.

Shrub, $2.5 \mathrm{~m}$ high; branchlets robust, $0.5 \mathrm{~mm}$ diam, glabrous; lenticels conspicuous. Leaves: blades oblong, $20-32$ by $6-10$ $\mathrm{cm}$, coriaceous, glabrous on both surfaces or sparsely puberulous on nerves beneath, brown when drying, apex cuspidate, margin recurved, base acute; midrib depressed above, prominent beneath, nigrescent, nerves slightly prominent above, strongly prominent beneath, 10-12 pairs, ascending at an angle of $70-90^{\circ}$, curved to the margin, nervules prominent on both surfaces, reticulate; petioles $5-10 \mathrm{~mm}$ long, glabrous. Stipules triangular, $4-5$ by $4-5 \mathrm{~mm}$, glabrous. Inflorescences axillary, sessile; bracts inconspicuous or small, triangular, 1-2 $\mathrm{mm}$ long. Flowers fascicular, sessile; calyx $7-8 \mathrm{~mm}$ long, thinly puberulous outside, lobes $4-5$, oblong, 4-5 mm long, $2.5 \mathrm{~mm}$ broad, rounded or obtuse at apex; corolla c. $1 \mathrm{~cm}$ long, glabrous outside, lobes $4-5$, ovate, thinly puberulous external surface, floccose internal surface. Fruits not seen.

Distribution - Endemic to Borneo (Sarawak). 


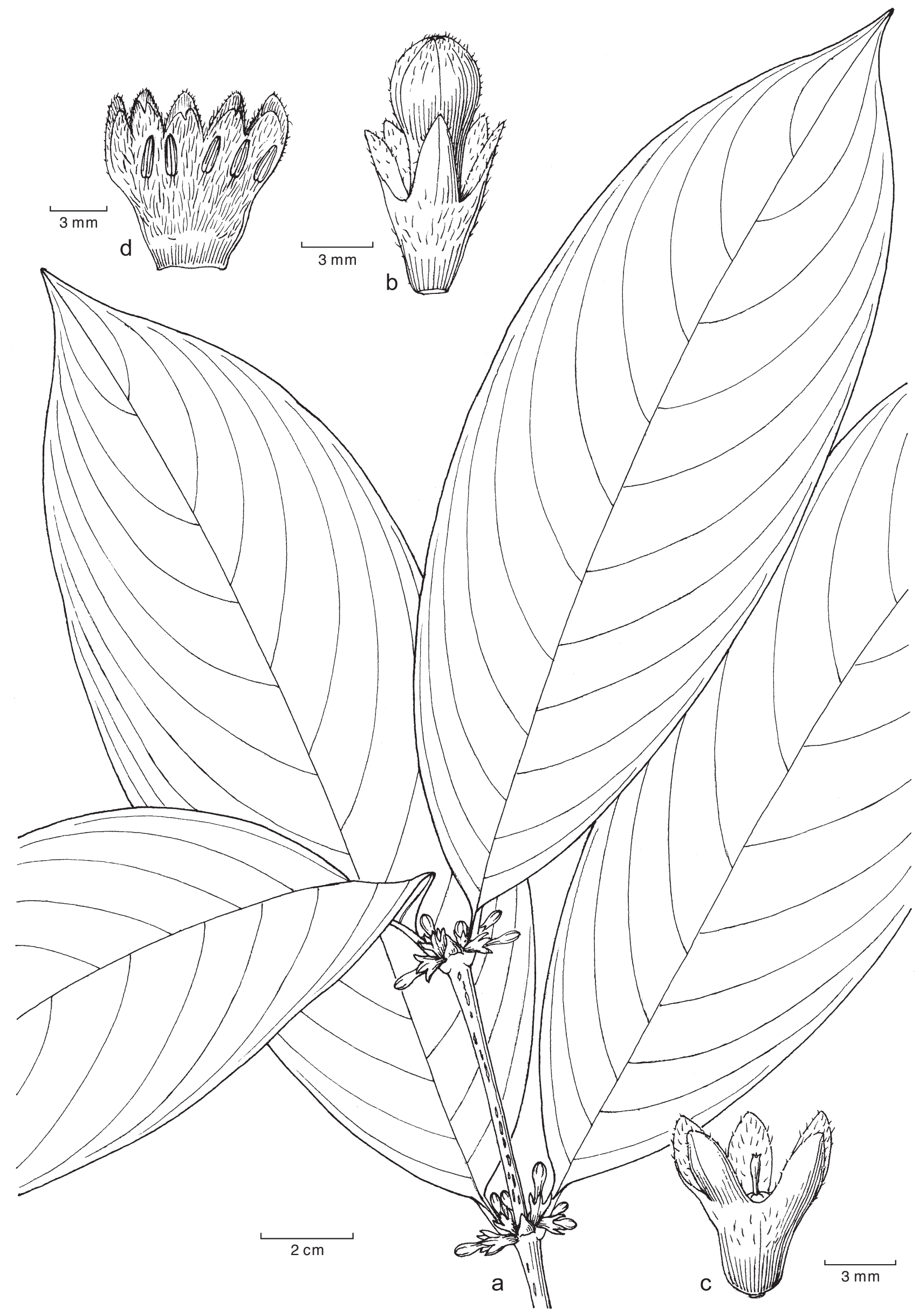

Fig. 32 Lasianthus pseudolongifolius H.Zhu. a. Habit with inflorescences; b. flower; c. calyx; d. corolla split opened (all: Bernard Lee S.39988, holo L). 
Habitat \& Ecology - In primary forest near stream bank between 800-1000 m altitude. Flowering between December and March.

Additional specimen examined. Sarawak, G.H. Pickles 3673 (L).

Note - This species looks like $L$. longifolius except the quite different flowers and relatively small stipules. It has a calyx divided into clear lobes; calyx lobes $4-5$, oblong, obtuse or rounded at apex, $4-5 \mathrm{~mm}$ long, $2.5 \mathrm{~mm}$ broad; calyx tube $3 \mathrm{~mm}$ long; stipules triangular, 4 by $4 \mathrm{~mm}$. Lasianthus longifolius has calyx with an enlarged cupular limb and truncate apex; stipules up to $1 \mathrm{~cm}$ long.

\section{Lasianthus pseudo-stipularis Amshoff ex Bakh.f.}

Lasianthus pseudo-stipularis Amshoff ex Bakh.f. (1963) 64; (1965) 340. Type: Winckel 1916ß (holo L), W Java, Tjadasmalang (SW Tjidadap, Priandgan), $1000 \mathrm{~m}$ alt.

Shrubs, 1-2 m high; branchlets terete, 2-3 mm diam, glabrous, dark-brown when dry. Leaves: blades oblong to ellipticoblong or oblong-obovate, $10-15$ by $3.5-5 \mathrm{~cm}$, glabrous on both surfaces, apex cuspidate-acute, base acute, dark-brown when dry, midrib and nerves flat to slightly prominent above, prominent beneath, nerves 7-8 pairs, ascending at an angle of $50-60^{\circ}$, curved to the margin, nervules slightly obscure above, distinct beneath, subparallel; petioles $5-8 \mathrm{~mm}$ long, glabrous. Stipules ovate to ovate-triangular, $5-7$ by $5 \mathrm{~mm}$, with thinly membranaceous margin, glabrous. Cymes sessile, bracts minute, inconspicuous. Flowers sessile; calyx glabrous, c. $2 \mathrm{~mm}$ long, tube obconic, c. $1 \mathrm{~mm}$ long, limb shallowly cupular, c. 1 $\mathrm{mm}$ long, truncate or obscurely 4-5-toothed; corolla c. $1 \mathrm{~cm}$ long, glabrous outside, tube c. $6 \mathrm{~mm}$ long, lobes c. $4 \mathrm{~mm}$ long, glabrous outside, pilose inside; anthers 5. Drupes turbinateglobose, c. $5 \mathrm{~mm}$ long, glabrous, verrucose, 4-ridged; pyrenes 4 , verrucose on the abaxial face.

Distribution - Indonesia (Sumatra, Java).

Note - This species differs from $L$. stipularis by having cymes without numerous hirsute bracts.

\section{Lasianthus purpureus Blume}

Lasianthus purpureus Blume (1826-1827) 1000; Miq. (1857) 324; (1869) 249; Bakh.f. (1965) 336. - Type: Blume s.n. (lecto L, designated here, barcode L0057519), Java.

Lasianthus umbellatus Kuntze (1891) 290; Bakh.f. (1965) 336, syn. nov. Possible type: Kuntze 4565 (NY), Java, Tjiboday.

Lasianthus glaber Scheff. ex Valeton (1914) 293, t. 400. - Type: Valeton s.n. (holo L, barcode L0012041), Java, Preanger, Tjibodas.

Treelets, up to $4 \mathrm{~m}$ high; branchlets terete or slightly compressed in the youngest part, c. $2 \mathrm{~mm}$ diam, glabrous. Leaves: blades lanceolate to oblong-lanceolate or ovate-lanceolate, $12-20$ by $2-3.5 \mathrm{~cm}$, glabrous on both surfaces, apex acuminate to caudate-acuminate, base acute, midrib and nerves prominent on both surfaces, nerves 5-6 pairs, ascending at an angle of over $60^{\circ}$, curved to the margin, nervules distinct and prominent on both surfaces, reticulate; petioles c. $1 \mathrm{~cm}$ long, glabrous. Stipules small, subulate, c. $1 \mathrm{~mm}$ long, glabrous. Cymes sessile, tuberculate; bracts absent. Flowers fascicular, pediceled; pedicels $8-10 \mathrm{~mm}$ long, glabrous; calyx c. 1.5-2 $\mathrm{mm}$ long, glabrous, tube obconic, c. $1 \mathrm{~mm}$ long, limbs shallowly campanulate, c. $0.5-1 \mathrm{~mm}$ long, minutely 4-toothed; corolla tubular, up to $8 \mathrm{~mm}$ long, tube glabrous outside, lobes 4, lanceolate, c. $3 \mathrm{~mm}$ long, puberulous at the apex outside. Drupes subglobose, up to $6 \mathrm{~mm}$ diam, conspicuously 4-ridged, glabrous, verrucose; pyrenes 4 , verrucose on the abaxial face.

Distribution - Indonesia (Sumatra, Java).
Notes - Lasianthus purpureus is a glabrous plant. It has oblong-lanceolate to ovate-lanceolate leaves with clearly reticulate nervules, flowers fascicled with usually more than $5 \mathrm{~mm}$ long pedicels, calyx limb truncate to 4-dentate, drupes with usually 4-ribbed, verrucose and 4 pyrenes.

Lasianthus umbellatus cannot clearly be separated from $L$. purpureus. Bakhuizen van den Brink Jr. separated L. umbellatus from $L$. purpureus by its dentate calyx limb, shorter (5-8 $\mathrm{mm}$ long) corolla, 4 ribbed drupes and lanceolate to ovatelanceolate leaves; while $L$. purpureus has truncate calyx limb, 9-10 $\mathrm{mm}$ long corolla, $2-5$ but usually 4 ribbed drupes and lineari-lanceolate leaves. However, the diagnostic characters given by Bakhuizen van den Brink Jr. separating these two species are not strong.

In Blume's description of this species, more than one locality was mentioned. The sheet barcode L0057519 with Blume's handwriting and a local name Kahitutung on the label which matches most to the protologue, is recognised to be a syntype and chosen here as lectotype.

\section{Lasianthus reticulatus Blume}

Lasianthus reticulatus Blume (1826-1827) 1000; Miq. (1857) 324; (1869) 248; Valeton ex Winkler (1910) 569; Merr. (1921) 578; (1929a) 292; Bakh.f. (1965) 343. - Type: Blume s.n. (holo L, barcode L0000700; iso L, barcodes L0000701, L0000702), Java, Seriboe.

Lasianthus cinnamomoides Miq. (1857) 325. — Type: Zollinger (n.v.), Java, Passir Madang.

Lasianthus maingayi Hook.f. (1880) 188; King \& Gamble (1904) 132; Ridl. (1923a) 160; Craib (1934) 213; K.M.Wong (1989) 369; H.Zhu (2001b) 136, syn. nov. - Type: Kew Distr. 871 (Maingay 1699) (K), Peninsular Malaysia. Lasianthus caloneurus K.Schum. (1902) 339; Pit. (1924) 397. - Type: Schmidt 683 (holo C), Thailand, Chantaburi.

Lasianthus flavicans King \& Gamble (1904) 116. - Syntypes: Ridley 4394 (n.v.), 6927 (n.v.), Singapore; Scortechini s.n. (n.v.), Perak; Ridley 2223 (n.v.), King's collector 10974 (n.v.), Pahang.

Shrubs, c. $2 \mathrm{~m}$ high; branchlets terete, c. $2.5 \mathrm{~mm}$ diam, compressed in the youngest part, minutely appressed-pubescent. Leaves: blades elliptic-oblong to elliptic-oblanceolate, 20-26 by $6-9 \mathrm{~cm}$, thinly coriaceous or membranaceous, pale greenish when dry, glabrous above, minutely appressed-pubescent beneath, apex acuminate or caudate-acuminate, base acute, midrib, nerves and nervules conspicuous above, strongly prominent beneath, nerves $5-7$ pairs, ascending at an angle of $50-60^{\circ}$, curved to the margin, tertiary nervules parallel, quaternary nervules reticulate; petioles short, $5-10 \mathrm{~mm}$ long, minutely appressed-pubescent. Stipules small, triangular, acute at apex, c. $3 \mathrm{~mm}$ long, strigose. Cymes very short pedunculate or extremely congested; bracts usually absent. Flowers subsessile, crowned; calyx campanulate, c. $2 \mathrm{~mm}$ long, constricted somewhat below the 3-4 triangular teeth, appressed-pubescent; corolla tubular, c. $6 \mathrm{~mm}$ long, with 3-4 lobes, glabrous outside, pubescent inside; ovary with 3-4 locules. Drupes obliquely elliptic, narrowed at base, glabrous, rugose, 1-4-ridged; pyrenes $1-4$, verrucose, furrow on the abaxial face.

Distribution - S Thailand, Malaysia (Peninsular, Borneo), Singapore, Indonesia (Sumatra, Java, Kalimantan, Sulawesi), Brunei, Philippines (Palawan).

Notes - This species has appressed-pubescent branchlets and leaf midrib and nerves beneath; leaves large, ellipticoblanceolate to elliptic-oblong; nerves prominent beneath, 6-7 pairs; nervules reticulate; petioles short; stipules small, triangular; cymes tuberculate; calyx limb campanulate with 4 minute lobes; ovary 4-locular; drupes verrucose, constricted at the base of persistent calyx limb; pyrenes 1-4. Lasianthus maingayi cannot be separated from $L$. reticulatus.

This species is very closely related to $L$. constrictus. It differs from the latter by having densely appressed-pubescent on 


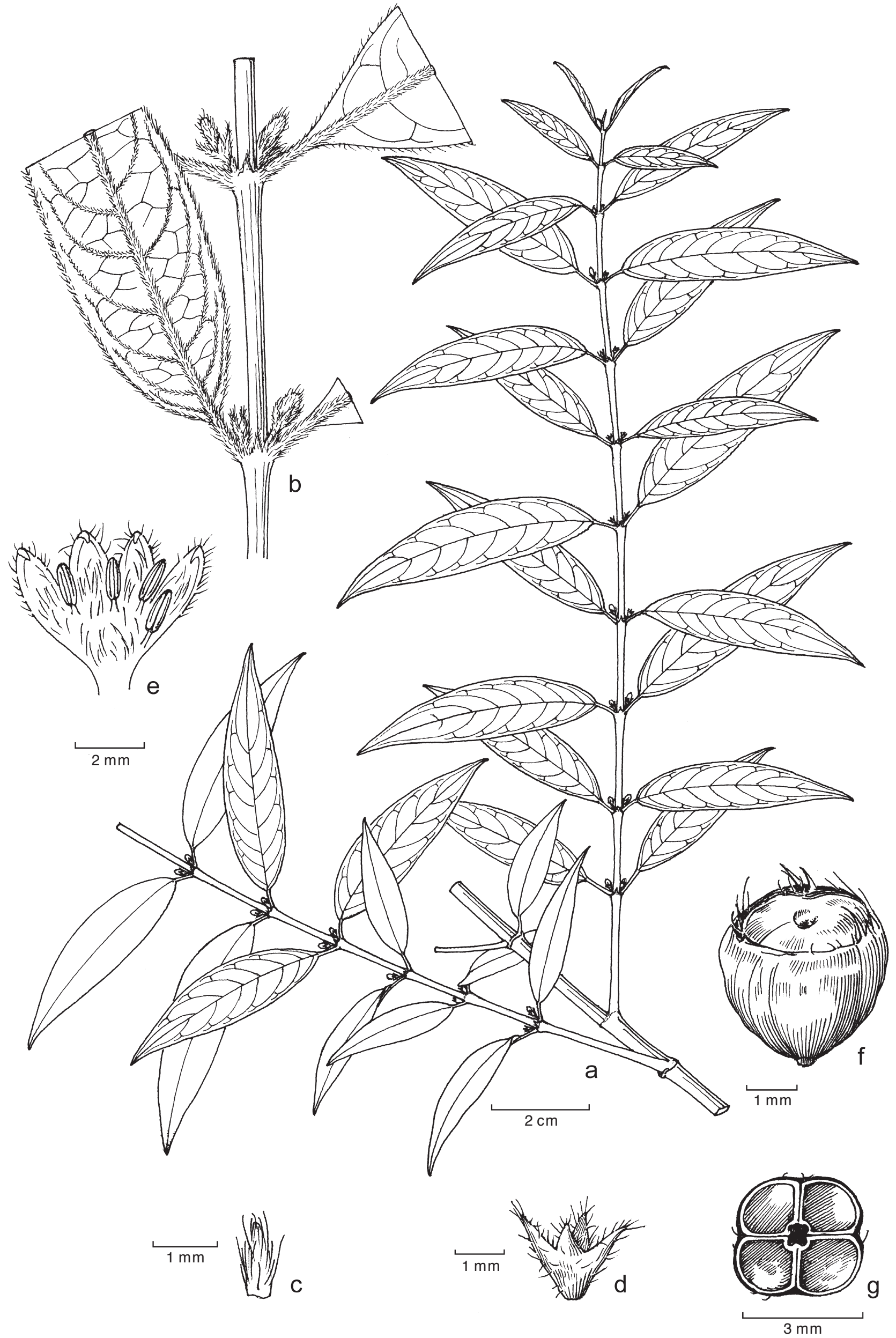

Fig. 33 Lasianthus ridsdalei H.Zhu. a. Habit with inflorescences; b. detail of branch showing stipule and axillary inflorescences; c. stipule; d. calyx; e. corolla split opened; f. fruit; g. cross section of fruit (a-e: C.E. Ridsdale SMHI1837; f, g: C.E. Ridsdale 1046, holo L). 
branches and nerves beneath, leaves relatively large with 6-7 pairs of nerves, flowers sessile clustered in very short congested peduncles, calyx limb with 4 minutely triangular lobes. Lasianthus constrictus has relatively small leaves with $3-5$ pairs of nerves and subglabrous or sparsely strigose branches and leaf nerves beneath, cymes usually sessile, calyx limb truncate or minutely toothed.

\section{Lasianthus rhinocerotis Blume}

Lasianthus rhinocerotis Blume (1826-1827) 996; Miq. (1857) 315; (1869) 245; Ridl. (1923a) 154; Merr. (1929a) 292; Bakh.f. (1965) 338; H.Zhu (1998) 154; (2001b) 140; (2002) 101. - Type: Blume s.n. (lecto L, designated by Zhu 2002, barcode L0000703), Java.

Shrubs, 1-2 m high; branchlets terete, usually robust, c. $3 \mathrm{~mm}$ diam, densely brown-villous. Leaves: blades oblong, oblonglanceolate or lanceolate, $9-18$ by $3-6.5 \mathrm{~cm}$, coriaceous, glabrous above, densely brown-villous beneath, apex cuspidateacuminate or cuspidate-acute, base subrounded, midrib and nerves usually depressed, rarely flat above, strongly prominent beneath, nerves $9-12$ pairs, ascending at an angle of over $50^{\circ}$, curved to the margin, nervules flat and slightly distinct above, prominent and distinct beneath, parallel; petioles $5-8 \mathrm{~mm}$ long, densely brown-villous. Stipules triangular, 2-3 mm long, densely brown-villous. Cymes shortly pedunculate; peduncles 2-5 mm long, densely brown-villous; bracts numerous, filiform to linear, 6-15 mm long, densely brown-villous. Flowers sessile; calyx tube c. $4 \mathrm{~mm}$ long, sparsely pilose outside, with usually 6 lobes, lobes linear-lanceolate, $3 \mathrm{~mm}$ long, densely villous; corolla tube $4 \mathrm{~mm}$ long with 5 lobes, lobes oblong, $3 \mathrm{~mm}$ long, densely hirsute outside. Drupes subglobose or obovate, c. 4 $\mathrm{mm}$ diam, pubescent or subglabrous, or slightly longitudinal angles, crowned with hirsute calyx lobes; pyrenes 5 .

Distribution - Thailand, Malaysia (Peninsular, Borneo), Brunei, Indonesia (Sumatra, Java, Kalimantan, Sulawesi, Irian Jaya).

Note - This species is characterized by having densely villose hairs on branchlets and leaves beneath, cymes with short and robust peduncles and numerous hairy filiform to linear bracts.

\section{Lasianthus ridleyi King \& Gamble}

Lasianthus ridleyi King \& Gamble (1904) 115; Ridl. (1923a) 154; Craib (1934) 216; K.M.Wong (1989) 371; H.Zhu (2001b) 140. - Type: Ridley 3620a (n.v.), Singapore.

Lasianthus reticulatus Blume var. polydasys Miq. (1869) 248. - Type: Korthals s.n. (holo L), Sumatra, syn. nov.

Lasianthus singaporensis King \& Gamble (1904) 117; Ridl. (1923a) 159. — Type: Ridley 9095 (holo SING), Singapore, Bukit Timah.

Lasianthus maingayi Hook.f. var. hirta Ridl. (1923a) 160. - Type: Ridley s.n. (iso K), Peninsular Malaysia, Negri Sembilan.

Shrubs, up to $2 \mathrm{~m}$ high; branchlets, terete, c. $2 \mathrm{~mm}$ diam, densely and softly tomentose. Leaves: blades elliptic to oblong-elliptic, $15-20$ by $3.5-7 \mathrm{~cm}$, membranaceous or thinly coriaceous, both sides olivaceous when dry, glabrous above, tomentose beneath, apex caudate-acute to acuminate, base broadly cuneate to subrounded, midrib and nerves flat or slightly prominent above, prominent beneath, nerves 5-10 pairs, ascending at an angle of over $50^{\circ}$, curved to the margin, nervules slightly distinct above, prominent and distinct beneath, subreticulate; petioles c. $5 \mathrm{~mm}$ long, densely tomentose. Stipules inconspicuous or triangular, c. $2 \mathrm{~mm}$ long, densely tomentose. Cymes subsessile, tuberculate; bracts numerous, linear with spreading hairs, up to 5-6 mm long. Flowers sessile; calyx campanulate, c. $1.5 \mathrm{~mm}$ long, glabrous, lobes $4-5$, triangular, c. $0.5 \mathrm{~mm}$ long, spreading hirsute at tip; corolla 6-7 mm long, clavate in bud, glabrous outside except for sparsely hairs on the lobes, villous inside.
Drupes subglobose, narrowed at base, glabrous, rugose, usually with 4 ridges; pyrenes 4 , very verrucose.

Distribution - Thailand, Singapore, Malaysia (Peninsular, Sabah), Indonesia (Sumatra, Kalimantan).

Notes - This species is very similar to L. reticulatus. It was treated as $L$. reticulatus var. polydasys and $L$. maingayi var. hirta. It differs from $L$. reticulatus ( $=L$. maingayi) by having spreading pubescens on branchlets and leaves beneath and numerous hairy linear bracts. It is better to treat it as a separate species.

Wong (1989) reduced $L$. singaporensis to a synonym of $L$. ridleyi. However, L. singaporensis differs from the typical $L$. ridleyi in having relatively narrow oblong-lanceolate leaves and shorter linear bracts.

\section{Lasianthus ridsdalei $\mathrm{H} . \mathrm{Zhu}, \mathrm{sp}$. nov. - Fig. 33}

Similis L. lucido Blume, sed foliis lanceolatis, nervis 7-9-binatis, costis nervis et marginis subtus hirsutis, stipulis hirsutis, bracteis 2 subulatis patenter hirsutis, floribus 4-meris minoribus patenter hirsutis, pyrenis 4 differt. A L. microphyllo Elmer foliis lanceolatis, nervis 7-9-binatis, costis nervis et marginis subtus hirsutis, stipulis hirsutis, bracteis 2 subulatis patenter hirsutis, floribus 4-meris minoribus patenter hirsutis, lobis calycis lanceolatis, pyrenis 4 differt. - Typus: C.E. Ridsdale 1046 (holo L), Philippines, Palawan, Infanta Mine area, $200 \mathrm{~m}$ alt., in lowland forest, 25 Oct. 1985.

Shrub, $1 \mathrm{~m}$ high; branchlets slender, terete, c. $1 \mathrm{~mm}$ diam, sparsely hirsute. Leaves: blades small, oblong-lanceolate to lanceolate, $3.5-5.5$ by $1.2-1.5 \mathrm{~cm}$, coriaceous, glabrous above, sparsely pubescent or glabrescent except hirsute midrib, nerves and margin beneath, apex acute to acuminate, margin hirsute, base acute, midrib depressed above, prominent and hirsute beneath, nerves 7-9 pairs, flat above, prominent beneath, ascending at an angle of c. $70^{\circ}$, curved to the margin, sparsely hirsute beneath, nervules obscure above, conspicuous beneath, reticulate, puberulous or glabrescent beneath; petioles 3-5 mm long, hirsute. Stipules subulate-triangular, c. $1 \mathrm{~mm}$ long, apex caudate, hirsute. Inflorescences sessile; bracts 2 , subulate, 2-3 $\mathrm{mm}$ long, spreading hirsute. Flowers solitary, sessile; calyx $2 \mathrm{~mm}$ long, sparsely spreading hirsute, tube c. 0.8 $\mathrm{mm}$ long, lobes 4, lanceolate, $1.2 \mathrm{~mm}$ long; corolla c. $5 \mathrm{~mm}$ long, spreading hirsute external surface on upper part, lobes 4 , hirsute external surface, floccose internal surface. Drupes globose, glabrous or sparsely hirsute, c. $3 \mathrm{~mm}$ diam, obtusely 4-ridged, smooth external surface; pyrenes 4 , smooth on the abaxial face, ovate-orbicular in transverse section.

Distribution - Endemic to Palawan (Philippines).

Habitat \& Ecology — In lowland forests on ultrabasic soil below $200 \mathrm{~m}$ altitude. Flowering in May; fruiting in October.

Additional specimen examined. Palawan, C.E. Ridsdale SMHI1837 (K, L).

Note - This species differs from L. lucidus by having leaves lanceolate, nerves 7-9 pairs, hirsute hairs on midrib, nerves, and margin beneath; stipules hirsute; bracts 2, subulate, spreading hirsute; flowers 4-merous, relatively small, spreading hirsute; drupes with 4 pyrenes. It differs from $L$. microphyllus by having leaves lanceolate, nerves 7-9 pairs, hirsute hairs on midrib, nerves, and margin beneath; stipules hirsute; bracts 2, subulate, spreading hirsute; flowers 4-merous, spreading hirsute; calyx lobes lanceolate; drupes with 4 pyrenes.

\section{Lasianthus rigidus Miq. - Map 7}

Lasianthus rigidus Miq. (1857)321; Bakh.f. (1965)340; H.Zhu (2002) 75. - Type: Junghuhn s.n. (lecto L, designated by Zhu 2002, barcode L0000704), Java, Pengalengan. Paratypes: Unknown collector s.n. (U, barcode U0006067); Junghuhn s.n. (L, barcode L0305517), Java, Kananga.

Lasianthus tentaculatus Hook.f. (1880) 181; Deb \& M.Gangop. (1991) 302 , f. 12; H.Zhu (1994) 58; H.S.Lo (1999) 105. - Type: Wall. Cat. 8306 (holo K), India, Silhet. 


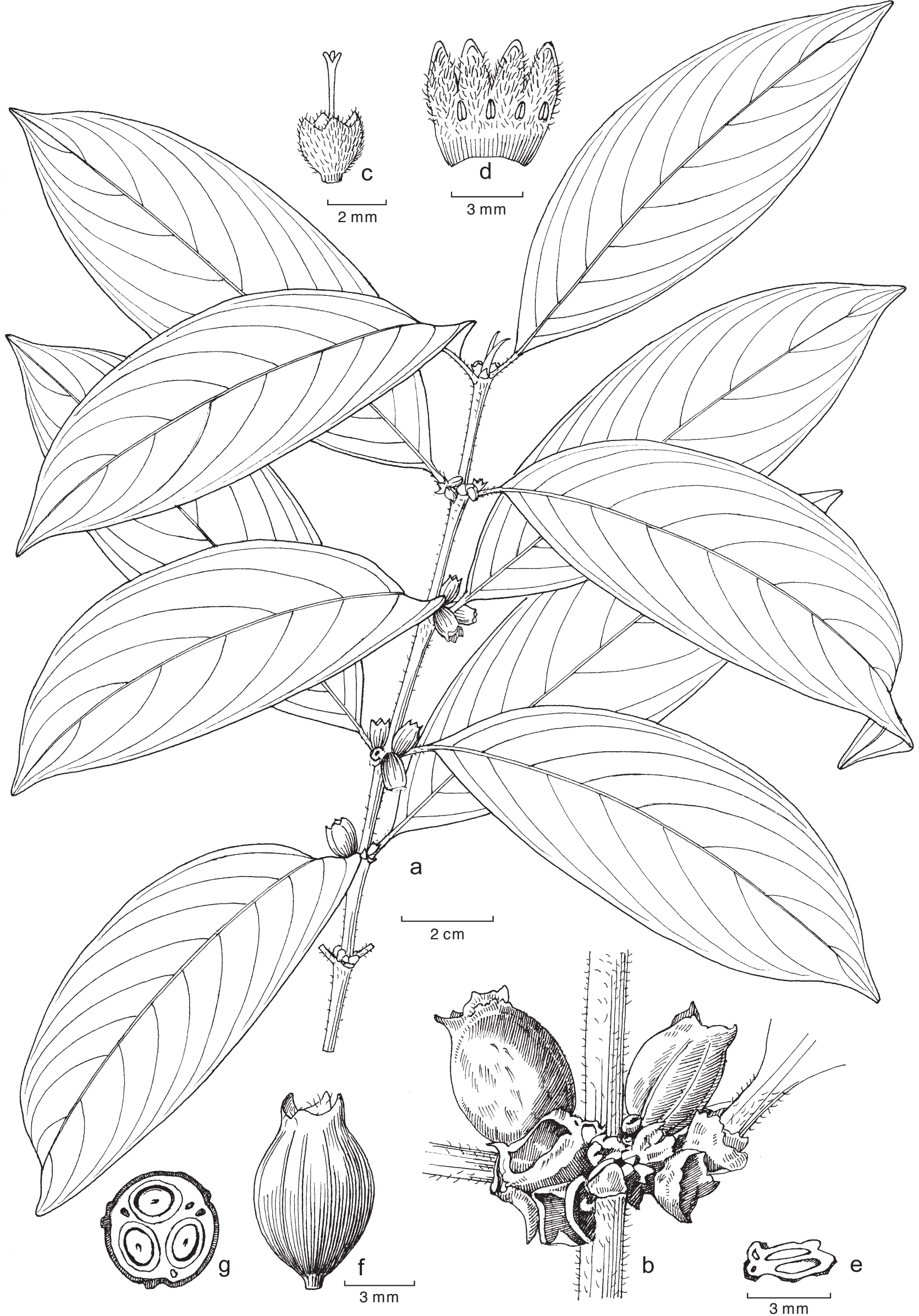

Fig. 34 Lasianthus sabahensis H.Zhu. a. Habit with fruit; b. detail of node showing stipule and axillary inflorescences; c. calyx; d. corolla split opened; e. cross section of ovary; f. fruit; g. cross section of fruit (all: Chew \& Corner RSNB 4598, holo L). 
Lasianthus humilis Elmer (1908) 519; Merr. (1923) 566. — Type: Elmer 9687 (holo lost; iso A, E, K, NY), Negros, Province of Negros Oriental, Cuernos Mountains, Dumaguete, Mar. 1908.

Shrubs, 1-1.5 m high; branchlets terete, robust, 2-3 mm diam, compressed and enlarged at nodes, glabrous or subglabrous. Leaves: blades obovate-oblong, obovate or oblong, $10-18$ by $3.5-7 \mathrm{~cm}$, coriaceous, glabrous above, hirsute on midrib, nerves, and nervules beneath, apex shortly cuspidateacuminate, base oblique, obtuse, slightly cordate or rounded, midrib and nerves flat above, prominent beneath, nerves 8-9 pairs, ascending at an angle of $50-60^{\circ}$, curved to the margin; nervules distinct above, prominent beneath, parallel; petioles 3-7 mm long, sparsely hirsute. Stipules persistent, triangular or subulate, 5-6 mm long, hirsute. Cymes sessile; bracts linear, linear-lanceolate to lanceolate, 9-12 mm long, numerous, hirsute. Flowers fascicular, sessile; calyx campanulate, 2-3 $\mathrm{mm}$ long, sparsely hirsute outside, with 5 triangular $1 \mathrm{~mm}$ long teeth; corolla c. $10 \mathrm{~mm}$ long, puberulous outside, pubescent inside in the upper part. Drupes globose, glabrous, 4-5 mm diam, crowned by hirsute calyx teeth; pyrenes 5 , smooth on the abaxial face.

Distribution - NE India, China (S Yunnan), Indonesia (Sumatra, Java), Philippines (Negros Oriental).

Note - This species has leaves obovate-oblong or obovate, 12-18 cm long, 5-7 cm broad, shortly cuspidate-acuminate at apex, the base oblique, obtuse, slightly cordate or rounded; stipules triangular or subulate, 5-6 mm long, hirsute; cymes sessile; bracts linear, linear-lanceolate to lanceolate, 9-12 mm long, numerous, hirsute; drupes globose, glabrous with 5 pyrenes.

\section{Lasianthus robinsonii Ridl.}

Lasianthus robinsonii Ridl. (1909) 37; (1923a) 169; K.M.Wong (1989) 373. Type: Ridley 13631 (holo SING; iso K), Peninsular Malaysia, Pahang, $4000-5000 \mathrm{ft}$.

Shrubs, 1-2 m high; branchlets terete, c. $2 \mathrm{~mm}$ diam, densely tomentose. Leaves: blades oblong, $12-16$ by $3.5-5 \mathrm{~cm}$, membranaceous or thinly coriaceous, glabrous above, pubescent hairs on midrib and nerves beneath, apex cuspidate-acute, base subrounded to rounded, midrib and nerves flat to slightly depressed above, prominent beneath, nerves 8-9 pairs, ascending at an angle of $60^{\circ}$ or more, curved to the margin, nervules distinct above, prominent beneath, subparallel; petioles 2-3 mm long, tomentose. Stipules triangular-lanceolate, 4-5 mm long, tomentose. Cymes long-pedunculate; peduncles slender, up to 5-6 cm long, tomentose; bracts 2, filiform, up to $8 \mathrm{~mm}$ long, tomentose; bracteoles like bracts but smaller, numerous. Flowers sessile; calyx c. $2.5 \mathrm{~mm}$ long, tomentose, lobes 4 , linear, longer than tube; corolla c. $6 \mathrm{~mm}$ long, hairy both inside and outside, tube short, lobes oblong, longer than the tube. Drupes obovoid, tomentose to subglabrous, crowned by long linear calyx lobes; pyrenes 4 .

Distribution - Endemic to Peninsular Malaysia.

\section{Lasianthus rotundatus Stapf}

Lasianthus rotundatus Stapf (1894) 185; Merr. (1921) 578. - Type: Haviland 1141 (holo K), Borneo, $8300 \mathrm{ft}$.

Shrubs, c. $1 \mathrm{~m}$ high; branchlets terete, c. $1.5 \mathrm{~mm}$ diam, glabrous, slightly compressed in the youngest part, darkish when dry. Leaves: blades oblong-rounded, subrounded or rounded, $3-6$ by $2-4.5 \mathrm{~cm}$, coriaceous, glabrous on both surfaces, apex shortly cuspidate or apiculate, base rounded, blackish when dry, midrib and nerves prominent on both surfaces or slightly depressed above, nerves c. 5 pairs, ascending at an angle of $70-80^{\circ}$, curved to the margin, nervules prominent and distinct on both surfaces, subparallel; petioles 3-6 mm long, glabrous. Stipules triangular, c. $1 \mathrm{~mm}$ long, glabrous or sparsely puberulous. Cymes sessile or subsessile (peduncles less than $2 \mathrm{~mm}$ long); bracts absent. Flowers sessile; calyx campanulate, c. $2 \mathrm{~mm}$ long, tube c. $1 \mathrm{~mm}$ long, glabrous, limb c. $1 \mathrm{~mm}$ long, puberulous outside, teeth 4 , broadly triangular, c. $0.6 \mathrm{~mm}$ long; corolla tube c. $4 \mathrm{~mm}$ long, lobes 4 , ovate, c. 2.5 mm long; stamens 4; ovary 4-locular. Drupes subglobose, 3-4 $\mathrm{mm}$ diam, glabrous; pyrenes 4 , smooth on the abaxial face.

Distribution - Endemic to Borneo (Sabah).

\section{Lasianthus sabahensis H.Zhu, sp. nov. - Fig. 34}

Similis $L$. sterophyllo Merr., sed limbis calycis 4 minute dentibus, ovariis 3-locularibus, pyrenis 2 raro 3 differt. - Typus: Chew \& Corner RSNB 4598 (holo L; iso K), Malaysia (Sabah), Mt Kinabalu, $5000 \mathrm{ft}$, Bembangan River, 1.3.1964.

Shrubs, up to $3 \mathrm{~m}$ high; branchlets terete, c. $2 \mathrm{~mm}$ diam, puberulous to subglabrous, more or less compressed in the youngest part. Leaves: blades oblong or lanceolate-oblong, $9-15$ by $2-5$ $\mathrm{cm}$, coriaceous, glabrous above, puberulous hairs on midrib and nerves beneath, apex acute to acuminate or cuspidate, margin reflexed, base cuneate, midrib prominent on both surfaces, nerves depressed or flat above, prominent beneath, 7-8 pairs, ascending at an angle of $60-80^{\circ}$, curved to the margin, nervules loosely anastomosing, subparallel, slightly prominent on both surfaces; petioles $1-1.5 \mathrm{~cm}$ long, puberulous. Stipules triangular, 4-6 mm long, with an acuminate to cuspidate apex, puberulous. Cymes sessile or shortly tuberculate; bracts absent. Flowers sessile, fascicular; calyx campanulate, tube c. 1 $\mathrm{mm}$ long, limb c. 1-1.5 mm long, more or less expanded, with 4 minute teeth, puberulous on both sides; corolla tubular, c. 5 $\mathrm{mm}$ long, puberulous outside, densely hairy in the upper half of the tube and the lobes inside, lobes 4; ovary 3-locular. Drupes ellipsoid, 8-9 mm long, c. $5 \mathrm{~mm}$ diam, puberulous or glabrous, crowned by a cupular calyx limb with 4 minute teeth, pyrenes 2 , rarely 3 , with thick, hard wall, smooth on the abaxial face, between pyrenes cork-like structure.

Distribution - Endemic to Borneo.

Habitat \& Ecology — In forest between 800-1800 m altitude. Flowering from September to January.

Notes - This species is similar to L. sterrophyllus, but differs in having relatively large stipules (4-6 mm long), calyx limbs with minute teeth, 3-locular ovary and 2-, rarely 3-pyrened drupes with cork-like structure between pyrenes, while $L$. sterrophyllus has stipules which are 3-4 mm long, calyx with 4 triangular lobes which are $2 \mathrm{~mm}$ long, and drupes with 5 pyrenes.

This species seems somewhat between Lasianthus and Saldinia morphologically. Saldinia has a 2-locular ovary which develops to a 1-pyrened drupe with a hard wall. Lasianthus has an ovary with 3 or more locules, which develops to a drupe with 1 or more pyrenes with a hard and thick wall. Lasianthus sabahensis has a 3-locular ovary which develops to a drupe with 2 rarely 3 pyrenes of hard and thick walls.

\section{Lasianthus scalariformis King \& Gamble}

Lasianthus scalariformis King \& Gamble (1904) 131; Ridl. (1923a) 167; M.R. Hend. (1933) 107; K.M.Wong (1989) 369. - Type: Scortechini 411 (lecto K, designated here), Peninsular Malaysia, Perak; Wray 332 (para, n.v.), Peninsular Malaysia, Perak, $6700 \mathrm{ft}$.

Shrubs or treelets, up to $4 \mathrm{~m}$ high; branchlets terete, c. $2 \mathrm{~mm}$ diam, thinly pubescent, dark in colour when dry. Leaves: blades lanceolate-oblong to elliptic-oblong, $10-15$ by $2.5-3.5 \mathrm{~cm}$, coriaceous, glabrous on both surfaces except sparsely pubescent hairs on midrib and nerves beneath, apex acuminate to acute, 


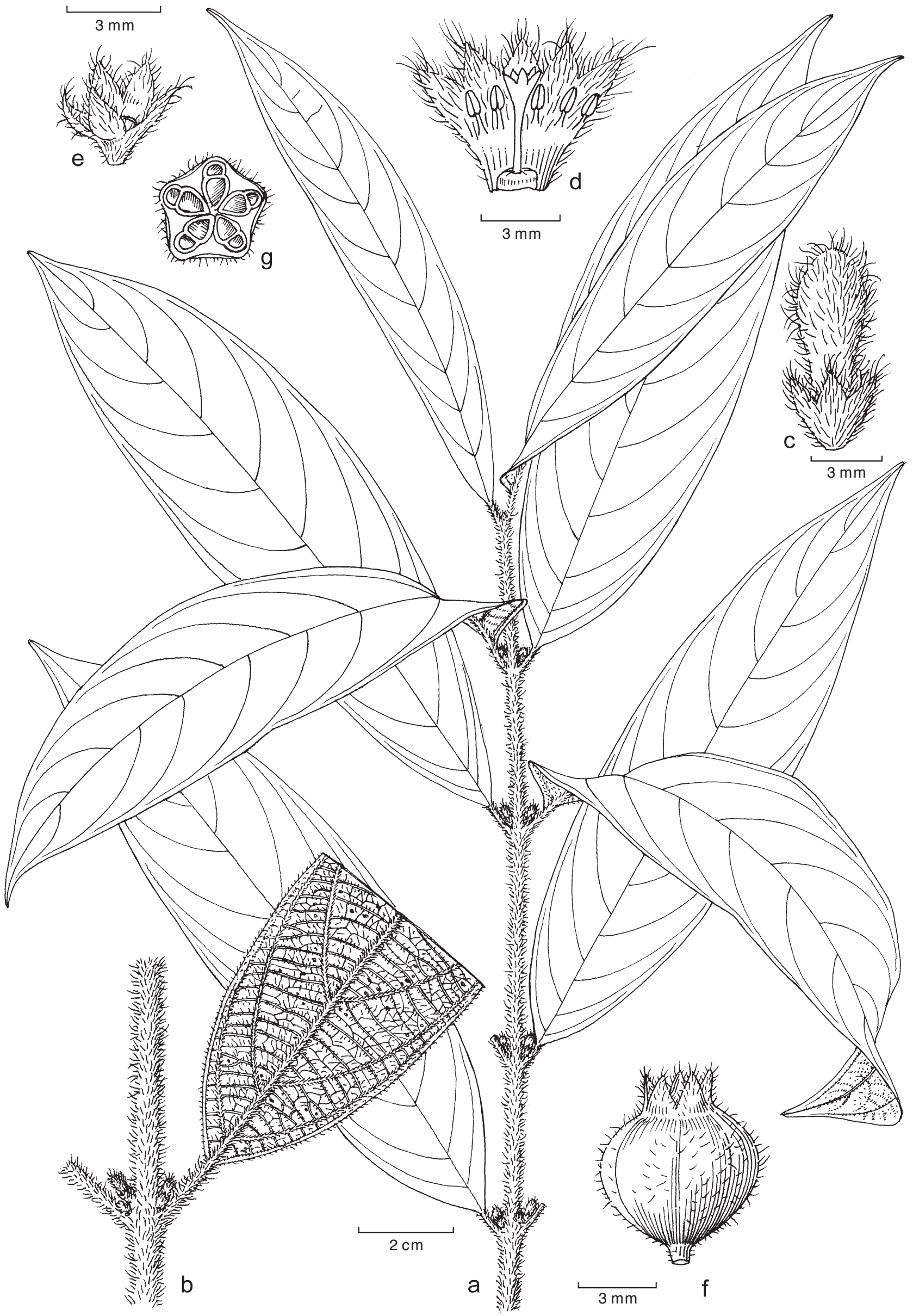

Fig. 35 Lasianthus setulosus H.Zhu. a. Habit; b. detail of node showing axillary inflorescences and lower surface of leaf; c. flower; d. corolla split opened; e. calyx; f. fruit; g. cross section of fruit (a-e: R. George et al. S.42843, holo L; f, g: W.M.A. Brooke 9115, L). 
base acute, midrib and nerves flat to slightly prominent above, strongly prominent beneath, nerves $7-8$ pairs, ascending at an angle of $50-60^{\circ}$, curved to the margin, nervules prominent on both surfaces, densely anastomosing, parallel; petioles 5-10 $\mathrm{mm}$ long, pubescent. Stipules triangular, $2-3 \mathrm{~mm}$ long, pubescent. Cymes pedunculate; main peduncles 5-10 mm long, robust, pubescent or glabrous with 2 branches; branches $2-4$ $\mathrm{mm}$ long, pubescent or glabrous; bracts minute, subulate, c. 2 $\mathrm{mm}$ long, pubescent; bracteoles c. $1 \mathrm{~mm}$ long. Flowers sessile; calyx tube obconic, c. 2-3 mm long, pubescent, lobes 5, oblong or ovate-oblong, 3-4 by $1.5 \mathrm{~mm}$, sparsely hirsute outside, puberulous inside; corolla tubular, 5-6 mm long, tomentose outside, lobes 5 , triangular-ovate; stamens 5 ; filaments very short c. $1.2 \mathrm{~mm}$ long. Drupes obovoid, 3.5-4 mm diam, glabrous, 5-ridged, crowned by persistent calyx lobes; pyrenes 5 .

Distribution - Peninsular Malaysia, Indonesia (Sumatra).

\section{Lasianthus setulosus H.Zhu, sp. nov. - Fig. 35}

Similis $L$. borneensis Merr., sed ramulis et foliis dense longiore hispidis, calycibus minoribus, lobis calycis ovato-triangulis, $1.5 \mathrm{~mm}$ longis, apice acutis differt. AL. piloso Wight foliis basi subrotundatis, bracteis inconspicuis, lobis calycis ovato-triangulis, $1.5 \mathrm{~mm}$ longis differt. - Typus: $R$. George et al. S.42843 (holo L; iso K), Borneo, Limbang, on lower slope, 11 Sept. 1980.

Shrub or treelet, 2-2.5 m high; branchlets terete, slightly compressed, c. $2 \mathrm{~mm}$ diam, densely dark-brown hispid. Leaves: blades elliptic-lanceolate, $10-17$ by $2.5-5 \mathrm{~cm}$, chartaceous to subcoriaceous, densely dark-brown hispid both surfaces, apex acuminate, base subrounded, slightly asymmetric, midrib depressed above, prominent beneath, densely hispid both surfaces or lower surface in old leaves, nerves slightly depressed and obscure above, prominent beneath, 9-12 pairs, ascending at an angle of c. $70^{\circ}$, curved to the margin, hispid, nervules obscure above, conspicuous beneath, subreticulate, hispid; petioles $0.5-1 \mathrm{~cm}$ long, densely hispid. Stipules subulatetriangular, c. $2 \mathrm{~mm}$ long, hispid. Inflorescences sessile, bracts inconspicuous. Flowers sessile, 5-merous; calyx campanulate, 3 by $3 \mathrm{~mm}$, hispid, lobes 5 , ovate-triangular, 1.5 by $1.5 \mathrm{~mm}$, sparsely hispid both surfaces; corolla $6 \mathrm{~mm}$ long, tube puberulous external surface, lobes 5-6, lanceolate, $2 \mathrm{~mm}$ long, hirsute external surface, floccose hairs on internal surface, densely white lanate at the mouth. Drupes globose, 4-5 mm diam, hispid, 5-ridged, crowned by the persistent 5 ovate-triangular calyx lobes; pyrenes 5 .

Distribution - Borneo (Sarawak, Sabah, Brunei).

Habitat \& Ecology — In forest. Flowering from September to November.

Additional specimens examined. Sarawak, G. Mulu, P.Chai S.39676 (L); Sg. Entulu, B. Lee S.54731 (L); Belarga, W.M.A. Brooke 9115 (L). Brunei, Temburong, C. Hansen 1622 (L), I. Nielsen \& H. Balslev 1086 (AAU); Sukang, D.W. Kirkup \& S. Thomas 619 (AAU). Sabah, Apensiangan Kayu, A. Mantor SAN 136864 (L).

Note - This species is similar to $L$. borneensis. It differs from the latter by having densely spreading long hispid on branchlets and leaves on both surface, calyx relatively small, 3 by $3 \mathrm{~mm}$, calyx lobes ovate-triangular with acute apex; while $L$. borneensis has very short hispid (strigose) on branchlets and leaves beneath, calyx 5 by $5 \mathrm{~mm}$, calyx lobes oblong with obtuse apex. It differs from $L$. pilosus by having leaves with subrounded base, bracts inconspicuous, calyx lobes ovatetriangular, $1.5 \mathrm{~mm}$ long. Lasianthus pilosus has leaves with subcordate base; bracts linear, $5 \mathrm{~mm}$ long; calyx lobes linear, up to $5 \mathrm{~mm}$ long or more.

\section{Lasianthus sikkimensis Hook.f.}

Lasianthus sikkimensis Hook.f. (1880) 180; Deb \& M.Gangop. (1991) 297; H.Zhu (1994) 60; (1998) 155; H.S.Lo (1999) 80, pl. 21: 6-11. - Type: Hooker \& Thomson 11 (holo K), Sikkim-Himalaya.
Lasianthus mindanaensis Merr. (1922) 466; (1923) 567. - Type: Bur. Sci. 38795 (Ramos \& Endano s.n.) (holo lost; iso K, L, US), Philippines, Mindanao, Mt Candoon, syn. nov.

Lasianthus langkokensis (Drake) Pit. (1924) 379. - Mephitidia langkokensis Drake (1895) 240. — Lasianthus sikkimensis Hook.f. subsp. langkokensis (Pit.) H.Zhu (1994) 61; (1998) 153. - Type: Balansa 2654 (holo P), Vietnam, Tonkin, Bavi.

Lasianthus baviensis (Drake) Pit. (1924) 380. - Mephitidia baviensis Drake (1895) 239. - Type: Balansa 2655 (holo P; iso K), Vietnam, Tonkin, Tu-phap. Lasianthus tsangii Merr. ex Li (1943) 458; H.J.Li \& H.Y.Liu (1998) 295. Type: Tsang 23940 (holo SCBI), China, Kwangsi [Guangxi].

Shrubs, 1-3 m high; branches and branchlets densely browntomentose. Leaves: blades elliptic-lanceolate or elliptic, 10-20 by $2.5-5 \mathrm{~cm}$, subcoriaceous or thinly coriaceous, glabrous above, densely brown-tomentose beneath, apex cuspidateacuminate, base acute or obtuse, usually recurved at margin, midrib and nerves flat above, conspicuously prominent beneath, nerves $7-10$ pairs, ascending at an angle of over $50^{\circ}$, curved to the margin, nervules subparallel, prominent beneath; petioles 6-14 mm long, brown-tomentose. Stipules triangular, 2-4 mm long, densely tomentose. Cymes sessile, 1-3-flowered; bracts persistent, linear to lanceolate, up to $2 \mathrm{~cm}$ long, brown-tomentose. Flowers sessile or subsessile; calyx 3-4 mm long, tube glabrous outside, lobes 5, triangular, hirsute outside; corolla c. $10 \mathrm{~mm}$ long, puberulous outside. Fruits ellipsoid, 6-8 mm long, glabrous except on the persisting hirsute calyx lobes; pyrenes 5 .

Distribution - NE India, Sikkim, Bangladesh, China, Vietnam, Thailand, Philippines.

Note - Lasianthus mindanaensis has branches rather densely brown-tomentose; leaves chartaceous to subcoriaceous, lanceolate, $11-18 \mathrm{~cm}$ long, apex caudate, base acute, nerves 7 , nervules rather distinct beneath, yellowish brown-tomentose on nerves and nervules beneath, petioles densely brown-tomentose; stipules ovate, 3-4 mm long, densely brown-tomentose; flowers sessile, fascicles, bracts narrowly lanceolate, $8 \mathrm{~mm}$ long, brown-tomentose; calyx tube glabrous, lobe $2 \mathrm{~mm}$ long, glabrous outside; drupes glabrous, $5 \mathrm{~mm}$ long. All of these characters agree well with $L$. sikkimensis. Lasianthus mindanaensis is conspecific with $L$. sikkimensis.

\section{Lasianthus sogerensis Wernham}

Lasianthus sogerensis Wernham (1918) 72. - Type: Forbes 313 (holo BM), New Guinea, Sogere, $3000 \mathrm{ft}$.

Shrubs, up to $2 \mathrm{~m}$ high; branchlets terete, c. $2 \mathrm{~mm}$ diam, densely spreading villous. Leaves: blades oblong to obovate-oblong, $7-11$ by $2-4 \mathrm{~cm}$, chartaceous, sparsely villous above but densely villous hairs on midrib, densely villous beneath, apex cuspidate-acuminate, base subrounded to rounded, more or less oblique, the margin ciliate, nerves obscure above, prominent and distinct beneath, 8-11 pairs, ascending at an angle of $50-60^{\circ}$, curved to the margin, nervules obscure above, distinct beneath, subparallel; petioles $2-5 \mathrm{~mm}$ long, densely villous. Stipules inconspicuous. Cymes sessile, bracts paired in each leaf axil, leaf-like, ovate-lanceolate to lanceolate, up to $1.5 \mathrm{~cm}$ long, nerved, long-villous, apex caudate with a linear tip. Flowers sessile; calyx tube campanulate, c. $3 \mathrm{~mm}$ long, densely villous, lobes 4 , linear-lanceolate, c. $3 \mathrm{~mm}$ long, villous; corolla tubular, c. $5 \mathrm{~mm}$ long, villous outside. Drupes globose, villous, c. $4 \mathrm{~mm}$ diam, 4-5-ridged, verrucose, crowned by linear-lanceolate calyx lobes; pyrenes $4-5$, verrucose on the abaxial face.

Distribution — Indonesia (Moluccan, Irian Jaya) and Papua New Guinea.

Note - This species has densely spreading villous hairs on branches, leaves, stipules, bracts, and drupes. It has chartaceous leaves with subrounded, or rounded and slightly oblique, 


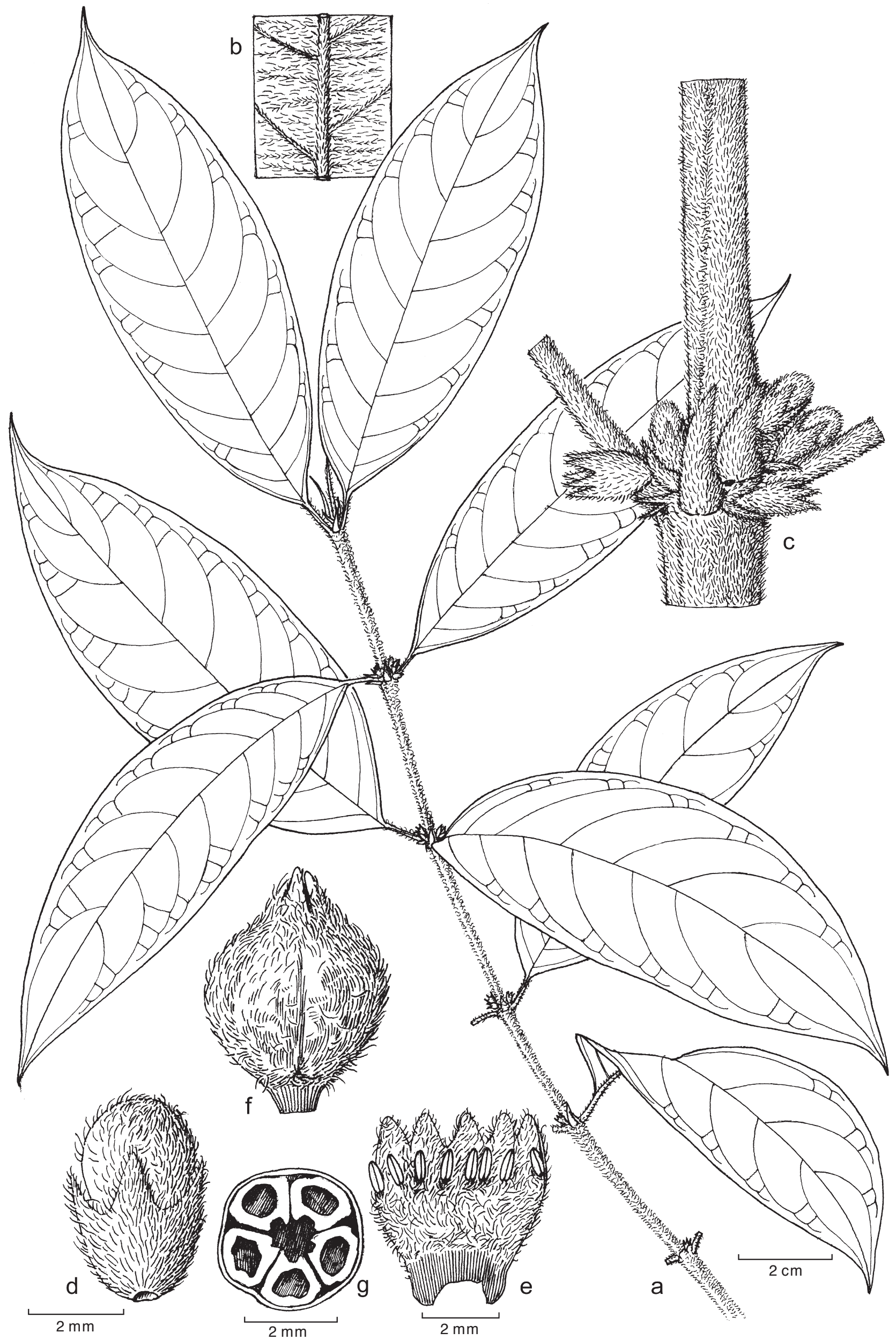

Fig. 36 Lasianthus solomonensis H.Zhu. a. Habit; b. detail of lower surface of leaf showing indumentum; c. detail of node showing stipule and axillary inflorescences; d. flower; e. corolla split opened; f. fruit; g. cross section of fruit (all: T.C. Whitmore RSS6051, holo L). 
bases, and ciliate margin, 8-11 pairs of nerves. Its stipules are inconspicuous but bracts are paired, leaf-like, ovate-lanceolate, with a long linear apex. It has drupes with 4-5 pyrenes crown by linear-lanceolate calyx lobes. This species is closely related to $L$. attenuatus and $L$. cyanocarpus, but differs from both of them by having densely patent or spreading villose hairs on the plant, bracts with a long linear apex. Furthermore, it differs from $L$. attenuatus by leaf-like paired bracts, and differs from L. cyanocarpus by ovate-lanceolate bracts paired in each leaf axil. Wernham (1918) did not mention bracts but described stipules with two long prongs ( $8 \mathrm{~mm}$ long), and also described the drupes with 2 pyrenes. In our observation of the specimens, which match type well, this species has inconspicuous stipules but conspicuously ovate-lanceolate bract pairs, and drupes with 4 pyrenes. Wernham could have called the bracts stipules.

\section{Lasianthus solomonensis H.Zhu, sp. nov. - Fig. 36}

Proximus L. chlorocarpus K.Schum., sed ramulis dense pubescentibus, floribus 5-7 meris, lobis calycis triangulato-subulatis aequalis tubo, drupis minoribus, pyrenis 5-7 differt. A L. clementis Merr. foliis majoribus, stipulis lineari-subulatis $5 \mathrm{~m}$ longis, floribus $5-7$-meris, bracteis subulatis $2 \mathrm{~mm}$ longis, lobis calycis aequalis tubo differt. - Typus: Whitmore RSS6051 (holo L), Solomon Islands, Guadalcanal, Mt Gallego, $2000 \mathrm{ft}$ alt., in very steep unstable hillside, 6 July 1965

Shrub, c. 1-2 m high; branchlets terete or compressed in the youngest part, c. $1.5 \mathrm{~mm}$ diam, densely appressed brownish pubescent. Leaves: blades elliptic-oblong, $10-12$ by 3-4 $\mathrm{cm}$, subcoriaceous, glabrous above, puberulous beneath, appressed-pubescent midrib and nerves beneath, apex cuspidate, with c. $2 \mathrm{~mm}$ long arista, margin slightly undulate and recurved, base acute; midrib flat or slightly prominent above, prominent beneath, nerves slightly prominent above, prominent beneath, $6-7$ pairs, ascending at an angle of $60-70^{\circ}$, curved to margin, nervules conspicuous beneath, parallel; petioles $0.8-1 \mathrm{~cm}$ long, densely pubescent. Stipules linear-subulate, c. $5 \mathrm{~mm}$ long, densely pubescent. Inflorescences sessile; bracts small, subulate, c. $2 \mathrm{~mm}$ long, pubescent. Flowers fascicular, sessile; calyx campanulate, c. $3 \mathrm{~mm}$ long, pubescent, lobes 5-7, triangular-subulate, c. $1.5 \mathrm{~mm}$ long, pubescent external surface, glabrous internal surface; corolla c. $5 \mathrm{~mm}$ long, pubescent external surface, lobes $5-7$, lanceolate; stamens 5-8, filament very short; styles c. $4 \mathrm{~mm}$ long, with 5-7 linear stigmas. Drupes globose, c. $3 \mathrm{~mm}$ diam, pubescent, crowned by $5-7$ subulate calyx lobes; pyrenes $5-7$, slightly verrucose on abaxial face, ovate on the transverse section.

Distributed - Solomon Islands.

Habitat \& Ecology — In primary forest between 300-2000 $\mathrm{ft}$ altitude. Flowering and fruiting between July and December.

Note - This species is closely related to $L$. chlorocarpus, but differs from the latter by having branchlets densely pubescent, flowers 5-7-merous, calyx lobes triangular-subulate, as long as calyx tube, drupes relatively small with 5-7 pyrenes. Lasianthus chlorocarpus has branchlets and leaf nerves beneath strigose, flowers 4-merous, calyx usually with a limb truncate or small dentate, drupes relatively big, pyrenes 4 . This species differs from $L$. clementis by having leaves relatively big, stipules linearsubulate, $5 \mathrm{~mm}$ long, flowers 5-7-merous, bracts subulate, 2 $\mathrm{mm}$ long, calyx lobes as long as calyx tube, drupes with 5-7 pyrenes.

\section{Lasianthus stercorarius Blume}

Lasianthus stercorarius Blume (1826-1827) 1000; Miq. (1857) 324; (1869) 248; Merr. (1921) 577; Bakh.f. (1965) 341. - Type: Blume s.n. (holo L, barcode L0000707), Java, Mt Tjerimai.

Lasianthus stercorarius Blume var. polypleura Blume ex Miq. (1869) 248, syn. nov. - Type: Blume s.n. (lecto L, designated here, barcode L0305599), Java; Blume s.n. (para L, barcode L0305583), Java.
Lasianthus mucronulatus (Korth.) Miq. var. lineata Miq. (1869) 249, syn. nov. - Type: Korthals s.n. (holo L, barcode L0310824), Sumatra.

Shrubs to treelets, up to $4.5 \mathrm{~m}$ high; branchlets terete, c. $2 \mathrm{~mm}$ diam, thinly appressed-puberulous or glabrous. Leaves: blades oblong-lanceolate to ovate-lanceolate, $7-15$ by $2-4 \mathrm{~cm}$, subcoriaceous to coriaceous, glabrous above, puberulous hairs on venation beneath or glabrous also, apex acuminate-caudate, base acute, midrib slightly depressed above, prominent beneath, nerves flat and slightly obscure above, prominent beneath, 5-9 pairs, ascending at an angle of $45-60^{\circ}$, curved to the margin, nervules obscure above, distinct beneath, subparallel; petioles 5-10 mm long, puberulous or glabrous. Stipules triangular, 3-6 mm long, coriaceous, swollen at the base, puberulous or glabrous. Cymes sessile; bracts absent. Flowers sessile; calyx urceolate or urceolate-cupular, c. 1.5-2 mm long, with a truncate or minutely toothed limb, puberulous or glabrous; corolla tubular, c. 5-7 mm long, puberulous outside. Drupes globose, glabrous or thinly puberulous, $3-5 \mathrm{~mm}$ diam, acute at the base, truncate or minutely toothed at the apex, conspicuously 6-9-ridged; pyrenes 6-9, smooth on the abaxial face.

Distribution - Malaysia (Peninsular, Borneo) and Indonesia (Sumatra, Java, Kalimantan, Sulawesi).

Habitat \& Ecology — In primary forest.

Notes - Lasianthus stercorarius is a very variable species in leaves, indumentum, and drupes. It is keyed out mainly by its conspicuously ovate-triangular stipules with swollen bases. The type specimen shows thin puberulous hairs on branches and leave nerves beneath; subcoriaceous leaves with 5-6 nerves and nervules reticulate, apex acuminate, base acute; calyx limbs subtruncate and with 4-5 minute teeth; drupes with 8-9 pyrenes. Two varieties were established: var. polypleura based on specimens with leaves of 8 pairs of nerves; var. palembanicus based on specimens with leaves of 12-14 pairs of nerves. The variety palembanicus is conspecific to L. mucronulatus and should be reduced to a synonym of the latter.

Lasianthus stercorarius differs from L. mucronulatus by having usually relatively small subcoriaceous leaves with acute to cuneate base and less than 10 pairs of nerves and conspicuously more than $2 \mathrm{~mm}$ long triangular stipules with swollen bases.

Lasianthus mucronulatus var. lineata was established on Korthals's Sumatra specimens. It has triangular stipules with swollen base, subcoriaceous leaves with much acute base and should be reduced to $L$. stercorarius.

\section{Lasianthus sterrophyllus Merr.}

Lasianthus sterrophyllus Merr. (1937) 299. - Type: Winkler 508 (holo HBG; iso NY), Borneo, Bukit Mulu, $950 \mathrm{~m}$ alt.

Shrubs or treelets, up to $3 \mathrm{~m}$ high; branchlets terete, 2-3 $\mathrm{mm}$ diam, glabrous except sparsely hirsute at nodes. Leaves: blades oblong-lanceolate, $8-13$ by $2.5-3.5 \mathrm{~cm}$, coriaceous, glabrous above, glabrous or sparsely hirsute hairs on midrib and nerves beneath, apex acute to caudate-acute, base acute, midrib and nerves slightly prominent above, prominent beneath, nerves $6-9$ pairs, ascending at an angle of $55-70^{\circ}$, curved to the margin, nervules prominent on both surfaces, subparallel; petioles 5-10 mm long, glabrous or sparsely hirsute. Stipules triangular, 3-4 mm long, coriaceous, glabrous or pubescent. Cymes sessile; bracts absent or inconspicuous. Flowers sessile calyx campanulate, subglabrous, tube c. $2 \mathrm{~mm}$ long, lobes 4 , triangular, c. $2 \mathrm{~mm}$ long, sparsely hirsute; corolla not seen. Drupes subglobose, c. $4 \mathrm{~mm}$ diam, glabrous or sparsely hirsute, crowned by persistent triangular calyx lobes; pyrenes 5 , smooth on the abaxial face.

Distribution - Malaysia (Sarawak), Indonesia (Kalimantan). 
Notes - This species is similar to L. inodorus subsp. montigenus. Lasianthus inodorus subsp. montigenus has conspicuous orbicular or ovate bracts (although they are usually caducous, you can always see some in most specimens) and is found above $1700 \mathrm{~m}$ altitude. Lasianthus sterrophyllus has inconspicuous bracts and has 4 ovate $2 \mathrm{~mm}$ long calyx lobes, and is usually found below $1700 \mathrm{~m}$ altitude.

An imperfect specimen in Leiden (Winkler 508) differs from the type description of $L$. sterrophyllus in having conspicuous ovate bracts. The label on the specimen looks quite new from the paper appearance and typing writing, and the date of collection 2/12/1925 does not agree with Merrill's type Winkler 508. The specimen obviously is $L$. inodorus subsp. montigenus.

\section{Lasianthus stipularis Blume}

Lasianthus stipularis Blume (1826-1827) 997; Miq. (1857) 319; (1869) 246; Kurz (1877) 30; Hook.f. (1880) 179; King \& Gamble (1904) 112; Elmer (1906b) 10; Ridl. (1923a) 152; Merr. (1929a) 292; Craib (1934) 217; K.M.Wong (1989) 368; H.Zhu (2001b) 141. - Mephitidia stipularis Korth. (1851) 223. - Type: Blume s.n. (holo L, barcode L0000708; iso L, barcode L0000709), Java, Salak.

Lasianthus stipularis Blume var. novoguineensis Valeton (1911) 498, syn. nov. - Type: Versteeg 1228 (holo L; iso K), SW New Guinea.

Shrubs, 1-2 m high, entirely glabrous except bracts and corolla; branchlets terete, $2-3 \mathrm{~mm}$ diam, compressed in the youngest part. Leaves: blades oblanceolate-oblong, $12-16$ by 3-5.5 cm, membranaceous, greenish brown when dry, apex cuspidate-caudate, base cuspidate-cuneate, midrib and nerves flat to slightly prominent above, prominent beneath, nerves 9-10 pairs, slender, ascending at an angle of over $50^{\circ}$, curved to the margin, nervules faint, subparallel; petioles $5-10 \mathrm{~mm}$ long; stipules broadly triangular-ovate, ovate or ovate-orbicular, larger, covering the cymes, up to $1.25 \mathrm{~cm}$ long and broad at base, membranaceous, glabrous, persistent. Cymes sessile; bracts numerous, linear to narrowly lanceolate, villous, up to 1.5 $\mathrm{cm}$ long, often exceeding the stipules. Flowers sessile; calyx campanulate, teeth broadly triangular, c. $1 \mathrm{~mm}$ long, hirsute; corolla not seen. Drupes ovoid-globose, glabrous, 4-5 mm diam, crowned with calyx limbs, with 4 obtuse ridges; pyrenes 4.

Distribution - Burma, Thailand, Malaysia (Peninsular, Borneo), Brunei, Indonesia (Sumatra, Java, Kalimantan, Sulawesi, Moluccas), Philippines, Papua New Guinea.

Note - This species has numerous hairy linear to narrowly lanceolate bracts up to $1.5 \mathrm{~cm}$ long, in which it differs from L. pseudostipularis (bracts minute and inconspicuous). Lasianthus stipularis var. novoguineensis differs from the typical variety by only having oblong to elliptic-lanceolate leaves, which is not enough to separate it from $L$. stipularis as a variety of the latter.

\section{Lasianthus subaureus Craib}

Lasianthus subaureus Craib (1933) 27; (1934) 218; K.M.Wong (1989) 368; H.Zhu (2001b) 142. — Type: Kerr 14117 (holo K; iso BK), Thailand, Puket.

Shrubs, up to $3 \mathrm{~m}$ high; branchlets terete, c. $2 \mathrm{~mm}$ diam, densely appressed puberulous, aureate when young. Leaves: blades oblong-lanceolate, $10-17$ by $1.7-3.5 \mathrm{~cm}$, coriaceous, glabrous, luteous above, pubescent hairs on midrib and nerves, or nervules beneath, apex acuminate, margin often reflexed, base acute to cuneate or rounded, slightly unequal-lateral, midrib conspicuous, more or less depressed above, prominent beneath, nerves prominent on both surfaces, c. 12 pairs, ascending at an angle of over $50^{\circ}$, curved to the margin, nervules distinct and slightly prominent on both surfaces, reticulate; petioles 10-15 mm long, densely appressed puberulous. Stipules triangular-subulate, $2.5-3 \mathrm{~mm}$ long, puberulous. Cymes sessile or rarely extremely congested; bracts absent. Flowers sessile; calyx cupulate, c. $4 \mathrm{~mm}$ long, appressed puberulous, tube 1.5-2 mm long, limb cupular, apex truncate or minutely teethed; corolla tubular, pubescent outside, tube up to $12 \mathrm{~mm}$ long, lobes 6 , linear or linear-lanceolate, pilose outside; ovary with 6 locules. Drupes subglobose, $4-5 \mathrm{~mm}$ diam, puberulous, conspicuously 5-6-ridged, base narrowed, apex crowned by a cupular and truncate or minutely toothed calyx limb; pyrenes $5-6$, smooth on the abaxial face.

Distribution — Burma, Thailand, Peninsular Malaysia.

Note - This species is close to L. verticillatus by its cupular calyx with truncate limb. It differs from the latter by having relatively narrow leaves with reticulate veinlets and longer petioles.

\section{Lasianthus subglobosus H.Zhu, sp. nov.}

Similis L. bruneensis H.Zhu, sed ramulis dense depressi-pubescentibus, foliis basi acutis, nervulis conspicuis, petiolis pubescentibus $5 \mathrm{~mm}$ longis et pyrenis 6 differt. - Typus: Puasa-Angian 3967 (holo K; iso L), Malaysia (Sabah), Tambunan, $1200 \mathrm{ft}$, 19/02/1934.

Treelet, $2 \mathrm{~m}$ high; branchlets terete, densely depressed-pubescent. Leaves: blades lanceolate to oblong-lanceolate, $8-12$ by $1.8-4.5 \mathrm{~cm}$, coriaceous, pubescent on leaf nerves beneath, apex acuminate or caudate, base acute, midrib and nerves conspicuously prominent on both surfaces, nerves 5-7 pairs, ascending at an angle of $50-60^{\circ}$, curved to the margin, nervules conspicuous on both surfaces, reticulate; petioles 0.5 $\mathrm{cm}$ long, pubescent. Stipules small, triangular, $1.5-3 \mathrm{~mm}$ long, pubescent. Inflorescences sessile, bracts inconspicuous. Flowers fascicular, sessile; calyx campanulate, $2 \mathrm{~mm}$ long, pubescent, calyx lobes 5, triangular, 1-2 mm long; corolla not seen. Drupes c. $3 \mathrm{~mm}$ diam, subglobose, puberulous, black, crowned by persistent small subulate-triangular calyx teeth; pyrenes 6 , shallow sulcate on the abaxial face, triangular in transverse section.

Distribution - Endemic to Borneo.

Habitat \& Ecology — In forest. Flowering and fruiting from February to December.

Note - This species is close to L. bruneensis, but differs from the latter in having branchlets densely depressedpubescent; leaves with an acute base, nervules conspicuous on both surfaces; petioles $5 \mathrm{~mm}$ long, pubescent; drupes with 6 pyrenes.

\section{Lasianthus submembranifolius Elmer}

Lasianthus submembranifolius Elmer (1913) 1871; Merr. (1923) 567. — Type: Elmer 14261 (iso A, CAS, K, L, MO, NY), Philippines, Mindanao, Mt Urdaneta, $3250 \mathrm{ft}$.

Shrubs; branchlets terete, c. $2 \mathrm{~mm}$ diam, compressed in the youngest part, glabrous. Leaves: blades ovate-oblong, 10-15 by $3-5 \mathrm{~cm}$, more or less unequal-lateral, thinly membranaceous, glabrous above, minutely puberulous hairs on midrib and nerves beneath, apex cuspidate-acute, base cuneate, asymmetric, midrib and nerves almost flat above, prominent beneath, nerves $4-5$ pairs, ascending at an angle of $40-50^{\circ}$, curved toward the margin and joining the nerves above very near the margin, forming an obscure intramarginal vein, nervules distinct beneath, loosely anastomosing, reticulate; petioles less than 1 $\mathrm{cm}$ long, glabrous. Stipules broadly ovate, c. 2 by $3 \mathrm{~mm}$, glabrous. Cymes tuberculate; bracts minute, numerous, subulate, $0.5-1 \mathrm{~mm}$ long, glabrous. Flowers shortly pediceled; pedicels 1-2 mm long, glabrous; calyx shallow-cupular, 1-2 mm long, glabrous, with 5 oblong-triangular lobes; corolla c. $1.5-3 \mathrm{~mm}$ long, glabrous outside, with 5 bluntly oblong lobes; stamens 5 ; 


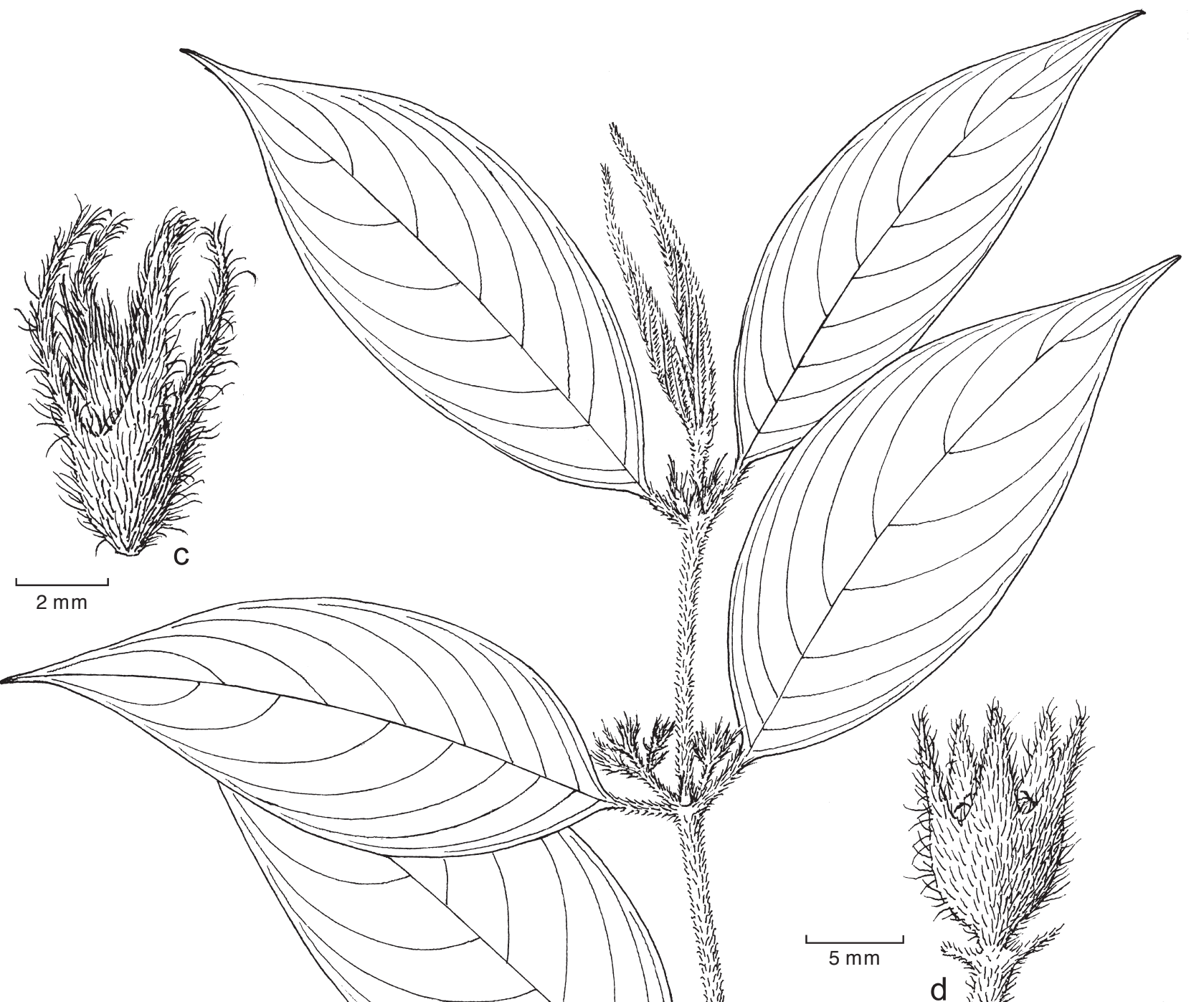

Fig. 37 Lasianthus sumatraensis H.Zhu. a. Habit with inflorescences; b. detail of inflorescence; c. calyx; d. fruit; e. cross section of fruit (all: W.J.O. de Wilde et al. 13225, holo L).

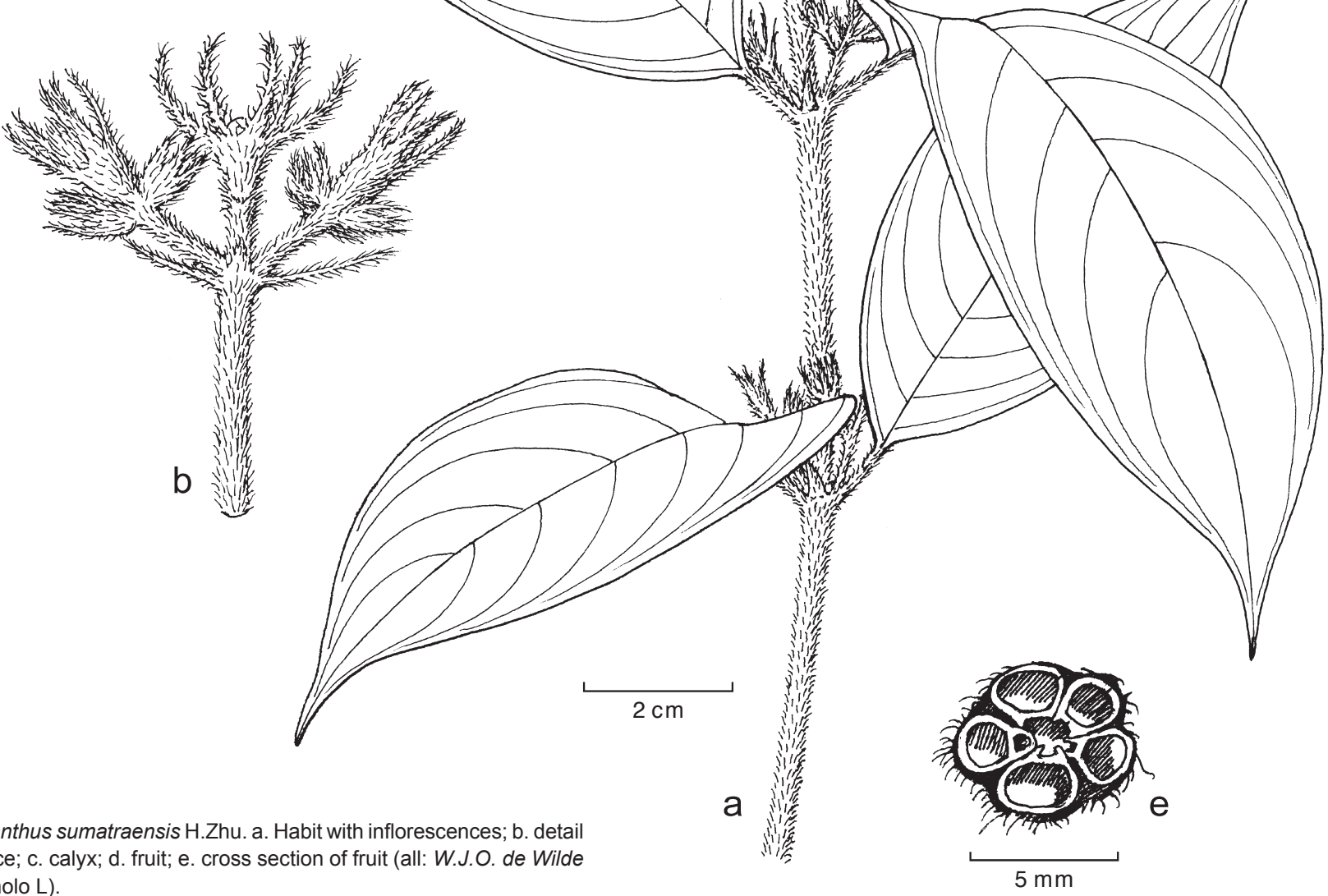


filament short. Drupes subglobose, up to $7.5 \mathrm{~mm}$ long; pyrenes 5 , coarsely rugose on the abaxial face.

Distribution - Endemic to the Philippines.

Note - According to Elmer's description, this species has rugose drupes with 5 pyrenes.

\section{Lasianthus sumatraensis H.Zhu, sp. nov. - Fig. 37}

Similis L. malaiense H.Zhu, sed foliis basi acutis praeter costae et nervis subtus glabris, cyma ramosa, floribus pedicellatis, lobis calycis linearis 5 mm longis differt. A L. scalariformis King \& Gamble ramulis dense brunneotomentosis, costis et nervis subtus brunneo-tomentosis, foliis ovato-ellipticis et lobis calycis linearibus tomentosis differt. - Typus: De Wilde et al. 13225 (holo L), North Sumatra, Kutatjane, 2500 m alt., in montane mossy forest, 23 June 1972.

Shrub, up to $4 \mathrm{~m}$ high; branchlets terete, densely brown tomentose. Leaves: blades ovate-elliptic, $7-11$ by $2.5-4.5 \mathrm{~cm}$, coriaceous, glabrous except venation beneath, apex acute to acuminate, margin ciliate, base acute to subrounded, midrib depressed above, prominent beneath, brown tomentose beneath, nerves flat above, prominent beneath, $6-7$ pairs, ascending at an angle of $50-60^{\circ}$, curved to the margin, tomentose beneath, nervules prominent on both surfaces, conspicuous, parallel, pubescent to glabrescent beneath; petioles $1-1.5 \mathrm{~cm}$ long, brown tomentose. Stipules lanceolate, 3-4 mm long, tomentose. Inflorescences cymose, brown tomentose; the main peduncles 5-10 $\mathrm{mm}$ long, peduncles branches (if present) c. $5 \mathrm{~mm}$ long; bracts linear, 2 in each node, $5 \mathrm{~mm}$ long, brown hirsute; bracteoles 2, linear, 3-5 mm long, brown hirsute. Flowers pedicellate; pedicels $1-3$ $\mathrm{mm}$ long, brown tomentose; calyx campanulate, densely brown tomentose, lobes 5, linear, 5-6 mm long, densely tomentose external surface. Drupes subglobose, 5-ridged, crowned by persistent linear, $5 \mathrm{~mm}$ long, calyx lobes; pyrenes 5 , smooth on the abaxial face, suborbicular in transverse section.

Distribution - Sumatra (northern part).

Habitat \& Ecology — In montane rainforest to mossy forest between 1600-2600 $\mathrm{m}$ altitude. Flowering and fruiting between May and August.

Additional specimens examined. North Sumatra, Atjeh, 2400-2600 m alt., W.J.O. de Wilde et al. 16785 (K, L); Atjeh, 1600-1800 m alt., K. Iwatsuki et al. S.958; Atjeh, Van Steenis 9545 (L).

Note - This species is quite similar to $L$. malaiense. It differs from the latter by having leaves with acute base, glabrous except venation beneath; cymes branched; flowers pedicellate; calyx lobes linear, $5 \mathrm{~mm}$ long. While $L$. malaiense has leaves with rounded base, villose beneath; cyme capitate; peduncles 2-3 cm long; flowers sessile; calyx lobes lanceolate, $2.5 \mathrm{~mm}$ long. It differs from $L$. scalariformis by having dense brown tomentose hairs on branchlets, leaf midrib and nerves beneath; ovate-elliptic leaves; calyx lobes linear, densely tomentose. While L. scalariformis has leaves subglabrous, elliptic-lanceolate; calyx lobes oblong-lanceolate, sparsely hirsute.

\section{Lasianthus sylvestroides Valeton}

Lasianthus sylvestroides Valeton (1927) 109; Merr. \& L.M.Perry (1946) 219. - Type: Ledermann 12655a (holo B十), New Guinea, Felsspitze, 14001500 m; Brass 13025 (neo L, designated here), New Guinea, Idenburg River.

Shrubs; branchlets terete, tomentose. Leaves: blades oblong or elliptic-lanceolate, $7-11$ by $2.5-4 \mathrm{~cm}$, subcoriaceous, glabrous above except tomentose midrib, tomentose beneath, apex acute to acuminate, mucronate, base acute, margin recurved, midrib flat above, prominent beneath, nerves flat to slightly depressed above, prominent beneath, 7-10 pairs, ascending at an angle of over $45^{\circ}$, curved to the margin, nervules prominent on both surfaces, parallel; petioles, c. 3-5 $\mathrm{mm}$ long, tomentose. Stipules linear-subulate, 4-5 mm long, tomentose. Cymes axillary, sessile or subsessile; bracts linear, 5-6 mm long, singular, tomentose. Flowers fascicular, sessile; calyx obconical, tube c. $2 \mathrm{~mm}$ long, hirsute, lobes 5, linear, 3-4 $\mathrm{mm}$ long, hirsute; corolla tomentose. Drupes globose, 4-5 $\mathrm{mm}$ diam, with $5-6$ obtuse ridges, verrucose, crowned by the persistent linear to lanceolate-subulate, 3-4 mm long, hirsute calyx lobes; pyrenes 5-6.

Distribution - Indonesia (Sulawesi, Irian Jaya), Papua New Guinea.

Note - The specimen Brass 13025 so closely fits the description of Valeton's species according to Merrill (Merrill \& Perry 1946) that we select it as a neotype.

\section{Lasianthus tenuifolius H.Zhu, sp. nov. - Fig. 38}

Similis L. attenuato var. minore H.Zhu, sed foliis tenui-chartaceis, stipulis subulato-linearibus, bracteis inconspicuis, fructibus glabribus et pyrenis 7-8 differt. - Typus: W. Ave 100 (holo L), Peninsular Malaysia, Perak, 550 m alt., in hill dipterocarp forest, 31 Aug. 1982

Shrub, $1 \mathrm{~m}$ high; branchlets slender, terete, spreading villous. Leaves: blades narrow-oblong to linear-oblong, 6-10 by $1.5-2.5 \mathrm{~cm}$, thinly chartaceous, sparsely spreading villous on both surfaces, densely on midrib and nerves, apex acute, margin ciliate, base rounded, oblique, midrib flat above, prominent beneath, nerves obscure above, slightly prominent beneath, $6-9$ pairs, ascending at an angle of $45-50^{\circ}$, curved to the margin; petioles short, 1-2 mm long, villous. Stipules subulate-linear, 3-5 mm long, villous. Inflorescences sessile; bracts inconspicuous. Flowers fascicular; calyx campanulate, 3-4 mm long, glabrous to sparsely villous on external surface, lobes 5 , triangular-lanceolate, $2.5 \mathrm{~mm}$ long, glabrous to sparsely villous; corolla 6-7 mm long, villous on external surface, lobes ovate-triangular. Drupes oblate-globose, $4-5$ by $3-4 \mathrm{~mm}$, glabrous, yellowish, 7-8 conspicuously sulcate; pyrenes 7-8, ovate-triangular in transverse section, smooth but with a furrow on the abaxial face, shallow furrow on the sides.

Distribution - Malaysia (Peninsular, Borneo) and Indonesia (Sumatra).

Habitat \& Ecology - In hill rainforest between 50-600 m altitude. Flowering and fruiting between August and November.

Additional specimens examined. W Kalimantan, Kohyama et al. K 10591 (L). Sarawak, P.Chai et al. S.31536 (L); C. Hose 156 (L). Brunei, M.J.E. Coode 6402 (L). Sabah, B.C. Stone SAN 85255 (K, L). Borneo, Bukit Raya, Veldkamp 8048 (L); Korth. s.n. W Sumatra, H. Nagamasu 3277 (L). Peninsular Malaysia, Selangor, KEP-FRI 1958 (L); Perak, W. Ave 24 (L); Pasoh, KEP-FRI 25703 (L); Pasoh, E.G.1532 (L).

Note - This species is quite similar to $L$. attenuatus var. minor. It differs from the latter by having thinly chartaceous leaves; nerves obscure upper surface; stipules subulate-linear; bracts inconspicuous; drupes glabrous; pyrenes 7-8. Lasianthus attenuatus var. minor has chartaceous to subcoriaceous leaves with conspicuous nerves upper surface; stipules linear-lanceolate; bracts conspicuous, linear to linear-lanceolate; drupes hirsute; pyrenes $4-5$. This species was confused with $L$. cyanocarpus ( $=$ L. inaequalis). Miquel (1857) doubted that a drupe with 8 pyrenes was found in $L$. inaequalis and later stated that drupes with 8 pyrenes do not occur in $L$. inaequalis (Miquel 1869). In our opinion, the specimens with 8-pyrened drupes present the new species.

\section{Lasianthus tomentosus Blume}

Lasianthus tomentosus Blume (1826-1827) 997; Miq. (1857) 318, p.p. quoad type specimens; (1869) 245; Bakh.f. (1965) 343. - Type: Blume s.n. (lecto L, designated here, barcode L0057521), Java.

Shrubs, c. $2 \mathrm{~m}$ high; branchlets terete, c. $2 \mathrm{~mm}$ diam, densely to thinly brown-tomentose. Leaves: blades ovate-oblong to 


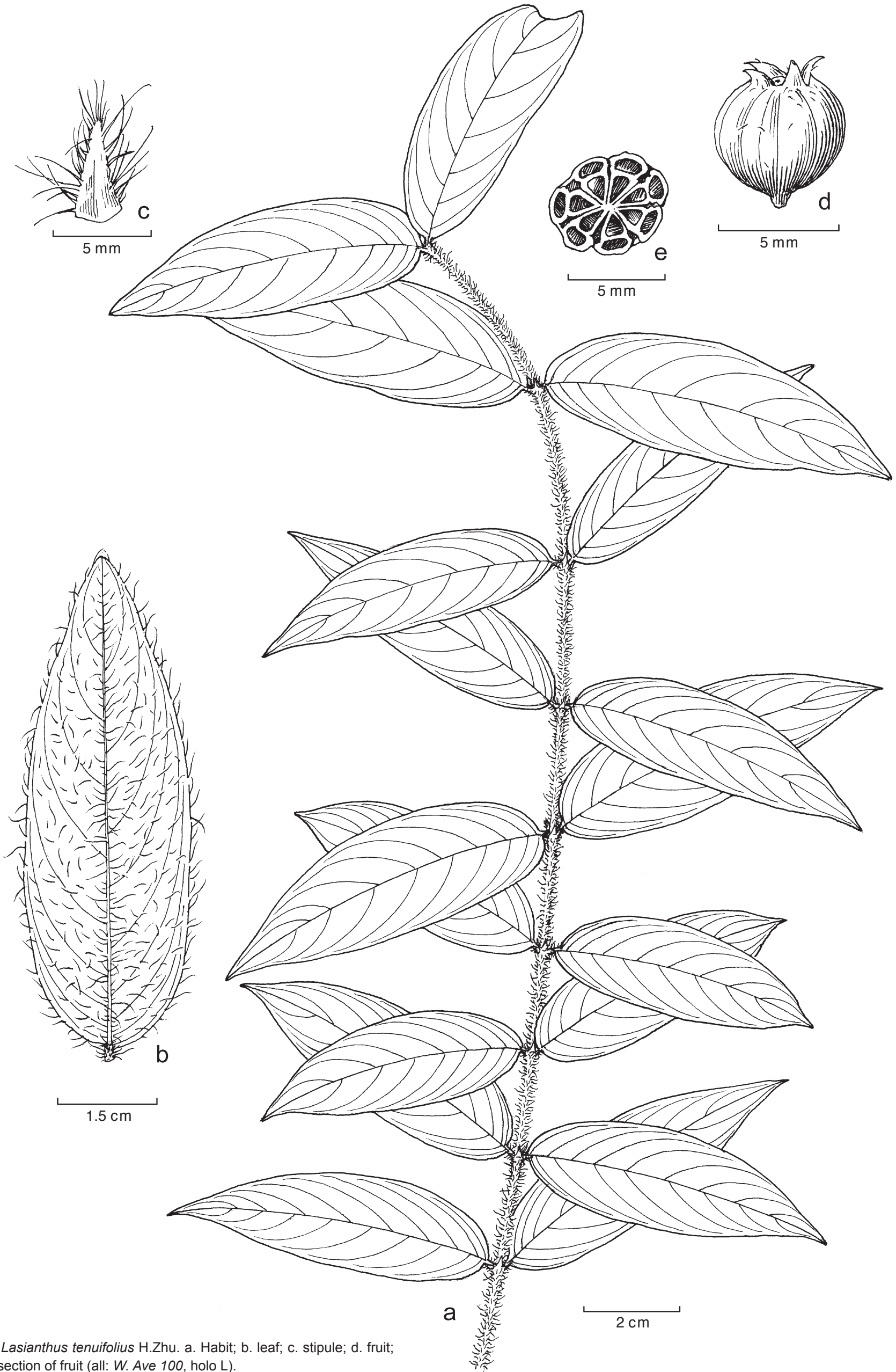

Fig. 38 Lasianthus tenuifolius $\mathrm{H}$ Zhu a. Habit; b. leaf; c. stipule; d. fruit e. cross section of fruit (all: W. Ave 100, holo L) 
oblong, $6.5-11$ by $2-4 \mathrm{~cm}$, thinly coriaceous, glabrous above, tomentose beneath, apex cuspidate-acute, aristate, base acute or broadly cuneate, midrib and nerves flat above, prominent beneath, nerves $3-6$, ascending at an angle of $50-60^{\circ}$, curved to the margin, nervules distinct above, prominent and distinct beneath, parallel; petioles 5-8 $\mathrm{mm}$ long, tomentose. Stipules triangular, $2-3 \mathrm{~mm}$ long, densely to sparsely tomentose. Cymes sessile; bracts absent. Flowers sessile; calyx campanulate, 2-3 $\mathrm{mm}$ long, tomentose, tubes c. $1 \mathrm{~mm}$ long, lobes 5 , lanceolate, c. 1.5-2 mm long; corolla 5-8 mm long, tomentose outside. Drupes subglobose, sparsely tomentose, crowned by lanceolate calyx lobes; pyrenes 5 .

Distribution — Indonesia (Java, Sulawesi, Irian Jaya), Papua New Guinea.

Notes - This species was confused with L. trichophlebus var. latifolius $(=L$. hiiranensis or Lasianthus tomentosus var. hiiranensis (Hayata) H.Zhu). The specimens from mainland SE Asia and Peninsular Malaysia were treated as L. tomentosus (King \& Gamble 1904, Ridley 1923a, Craib 1934) which may be due to two misidentified sheets in Kew. Based on the same sheets, they were treated as $L$. tomentosus var. hiiranensis. These two specimens in Kew, Horsfield s.n. [Rub. 50] from Java, are indicated as $L$. tomentosus in Miquel's handwriting and were cited as such in literature (Miquel 1857). Miquel later changed his mind and considered that they were not the same as L. tomentosus (Miquel 1869). The type material of $L$. tomentosus is only present in Leiden. It is difficult to correctly recognize L. tomentosus based on the simple original description without examining type material. The specimens from mainland SE Asia and Malaysia which were mistaken as L. tomentosus, have conspicuous strigose linear-lanceolate stipules, 4-merous flowers, hirsute and verrucose drupes with 4 pyrenes and are more closely related to $L$. trichophlebus than to $L$. tomentosus; we include them in L. trichophlebus var. latifolius.

Lasianthus tomentosus differs from L. lucidus in having tomentose hairs on branchlets, leaf lower surface, and flowers. The population from Java has dense tomentose hairs, but the populations from Sulawesi and New Guinea become less hairy and are closer to L. lucidus.

Only one specimen annotated L. tomentosus in Blume's handwriting was seen in Leiden. However, Blume's description mentions several localities and consequently this specimen is a syntype. We have chosen it as the lectotype of Blume's species.

\section{Lasianthus trichophlebus Hemsl.}

\section{Key to the varieties}

1. Branches sparsely strigillose; leaves glabrous except strigillose or hirsute midrib and nerves beneath . . . . . . . . . $\ldots \ldots \ldots \ldots \ldots \ldots \ldots \ldots$. . var. trichophlebus

1. Branches densely hirsute, leaves pubescent beneath ...

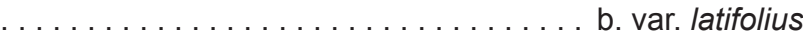

\section{a. var. trichophlebus - Map 10}

Lasianthus trichophlebus HemsI. (1888) 388; H.Zhu (1994) 70; H.S.Lo (1999) 95; H.Zhu (2001b) 144; (2002) 92. - Type: Ford 113 (holo K), Guangdong, Luo Fu Shan.

Lasianthus barbellatus Ridl. (1917a) 187; (1923a) 164; Craib (1934) 208; K.M.Wong (1989) 368. — Lasianthus trichophlebus Hemsl. subsp. barbellatus (Ridl.) H.Zhu (2001b) 144. - Type: Burkill 976 (holo SING; iso K), Peninsular Malaysia, Pahang, Pulau Tiuman, Juara Bay.

Lasianthus cupreus Pierre ex Pit. (1924) 392. - Type: Harmand s.n. (Pierre Herb. no. 6173) (lecto P, designated by Zhu 2001b), Vietnam, Condor.

Lasianthus andamanicus Hook.f. var. ciliatus Deb \& M.Gangop. (1987) 458, syn. nov. - Type: Balakrishnan 654 (holo CAL; iso E, PBL), S Andaman.

Shrubs; 1-2 m high; branchlets terete, c. $2 \mathrm{~mm}$ diam, sparsely strigillose or glabrous but densely strigillose on nodes. Leaves: blades oblong, elliptic-oblong, $8-15$ by $3-5 \mathrm{~cm}$, coriaceous, glabrous above, strigillose or hirsute on midrib and nerves beneath, apex cuspidate or acute, base cuneate, midrib and nerves flat or slightly prominent above, prominent beneath, nerves 7-9 pairs, ascending at an angle of over $50^{\circ}$, curved to the margin, nervules distinct above, prominent beneath, parallel; petioles $5-8 \mathrm{~mm}$ strigillose. Stipules triangular-lanceolate, to $8 \mathrm{~mm}$ long, densely strigillose. Cymes sessile, bracts absent. Flowers subsessile, 4-merous; calyx campanulate, c. $2 \mathrm{~mm}$ long, strigillose outside, tube c. $1 \mathrm{~mm}$ long, with 4 triangular teeth, teeth c. $1 \mathrm{~mm}$ long, spreading strigillose; corolla 6-8 $\mathrm{mm}$ long, densely strigillose in the upper half outside. Drupes subglobose, 5-6 $\mathrm{mm}$ diam, verrucose, sparsely strigillose, crowned by persistent strigillose calyx lobes; pyrenes 4 , verrucose on the abaxial face.

Distribution - India (Andaman and Nicobar Islands), South China, South Vietnam, Thailand, Peninsular Malaysia, Indonesia (Sumatra, Java, Sulawesi, Lesser Sunda Islands), Philippines (Palawan, Mindoro).

Notes - Lasianthus trichophlebus was often confused with both $L$. chinensis and $L$. verticillatus. However, it differs from

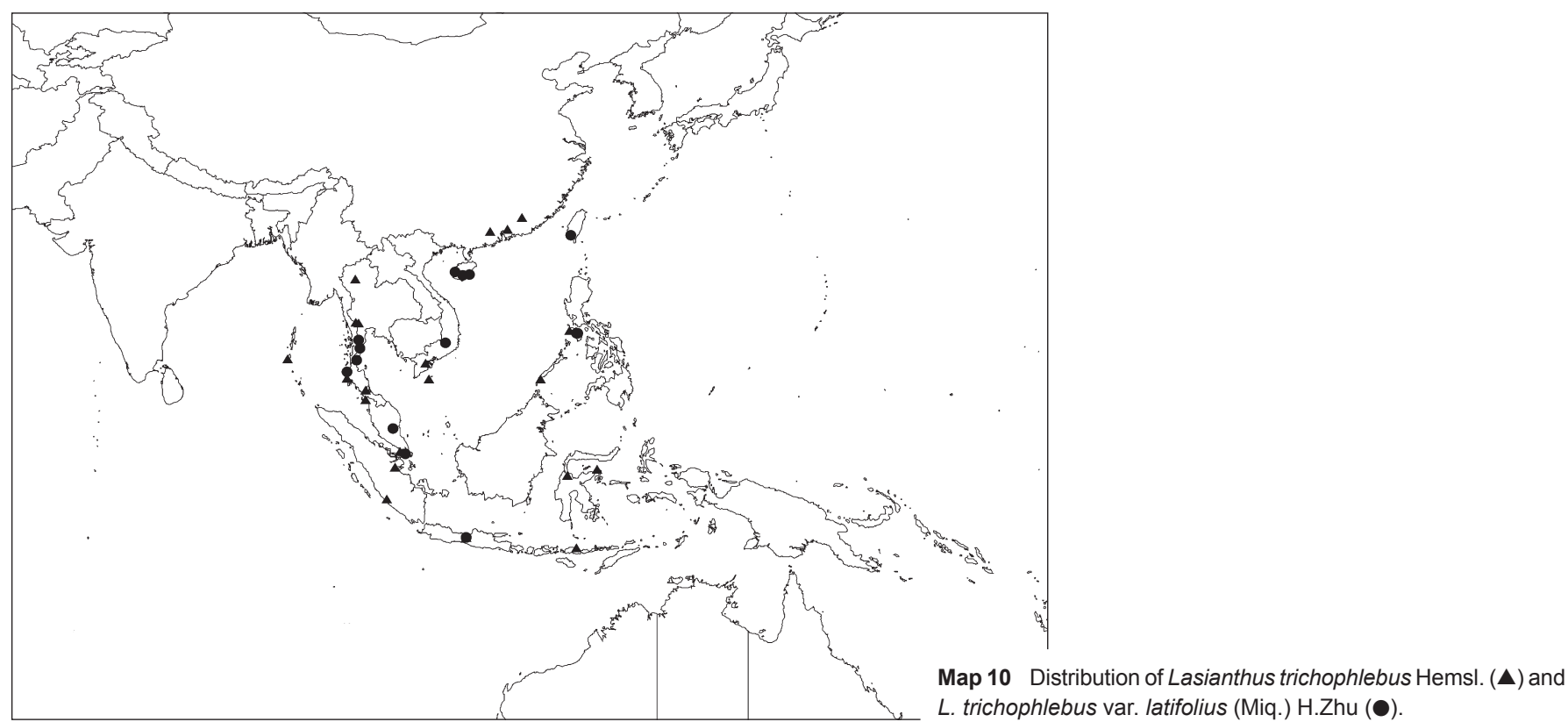


L. chinensis by having coriaceous leaves with 7-9 pairs of nerves and parallel veinlets; stipules triangular-lanceolate, strigillose, $5 \mathrm{~mm}$ long; flowers usually 4-merous as well as drupes with 4 pyrenes. It differs from $L$. verticillatus by having strigillose hairs on young branches and leaf nerves beneath; stipules triangular-lanceolate, strigillose, more than $5 \mathrm{~mm}$ long; flowers usually 4-merous; calyx with strigillose triangular lobes, and drupes with 4 pyrenes and verrucose on external surface.

Lasianthus trichophlebus subsp. barbellatus was considered to be different from the typical subspecies by having relatively small and elliptic leaves. After more Malesian specimens were examined, it became clear that $L$. trichophlebus subsp. barbellatus cannot be separated from $L$. trichophlebus.

\section{b. var. latifolius (Miq.) H.Zhu}

Lasianthus trichophlebus var. Iatifolius (Miq.) H.Zhu (2002) 93. - Lasianthus sylvestris Blume var. latifolius Miq. (1869) 248. - Type: Korthals s.n. (lecto L, designated here, barcode L0305397), Java, Papandajang; Teysmann s.n. (para, n.v.), Sumatra, Loeboe.

Lasianthus hiiranensis Hayata (1919) 62; Shimizu (1944) 239; T.S.Liu \& J.M.Chao (1964) 134, f. 9; J.M.Chao (1978) 295, pl. 1010; H.Zhu (1994) 70; H.J.Li \& H.Y.Liu (1998) 287, pl. 128; H.S.Lo (1999) 87. — Lasianthus tomentosus Blume var. hiiranensis (Hayata) H.Zhu (1998) 156. - Type: Hayata \& Sasaki 24295 (holo TIU, n.v.), China, Taiwan.

Lasianthus cupreus sensu Pit. (1924) 392, p.p. quoad specimen Gaudichaud 229.

Lasianthus lei Merr. \& Metcalf ex H.S.Lo (1993) 12; (1999) 86, pl. 16: 7-12. - Type: Lei 1025 (holo SCBI; iso K, P, SYS, US), China, Hainan. Lasianthus tomentosus auct. non Blume: Miq. (1857) 318, p.p. quoad specimen Horsfield s.n. from Java; King \& Gamble (1904) 130; Ridl. (1923a) 161; Craib (1934) 219; H.Zhu (1998) 155.

Distribution - China (Hainan, Taiwan), Vietnam, Thailand, Peninsular Malaysia, Indonesia (Java, Sumatra), Philippines.

Note - This taxon was treated as L. tomentosus (King \& Gamble 1904, Ridley 1923a, Craib 1934) which may be due to two misidentified sheets in K. These two specimens, which are labelled as Horsfield s.n. [Rub. 50] from Java, are indicated as L. tomentosus with Miquel's handwriting and also were cited in literature (Miquel 1857). Miquel (1869) later changed his mind and considered that they were not the same as $L$. tomentosus. The taxon which was mistaken as $L$. tomentosus, has conspicuous strigose linear-lanceolate stipules, 4-merous flowers, hirsute and verrucose drupes with 4 pyrenes and is closer related to $L$. trichophlebus than to $L$. tomentosus. The taxon differs from $L$. trichophlebus by having only dense hirsute hairs on the branches and pubescent hairs on the leaf lower surface. It is better to treat the taxon as a variety of $L$. trichophlebus. A Javanese taxon $L$. sylvestris var. latifolius is recognized to be conspecific with this taxon. Therefore the combination for the taxon is made as $L$. trichophlebus var. latifolius.

\section{Lasianthus undulatus H.Zhu, sp. nov. - Fig. 39}

Similis L. clementis Merr., sed ramulis dense tomentosis, foliis oblongi-lanceolatis rugosis margine undulatis, nervis 10-13-binatis, nervulis conspicue reticulatis et calycis limbis campanulatis differt. — Typus: Van Steenis 9886 (holo L; iso K), Sumatra, Atjeh, Gajalanden, $1100 \mathrm{~m}$ alt., in forest ridges, 20 Mar. 1937

Shrub, $4 \mathrm{~m}$ high; branchlets terete, c. $2 \mathrm{~mm}$ diam, densely brownish tomentose. Leaves: blades oblong-lanceolate, $6-11$ by $2-3$ $\mathrm{cm}$, chartaceous to subcoriaceous, puberulous or glabrescent above, puberulous beneath, rugose on both surfaces, apex acute or caudate-cuspidate, mucronate, margin recurved, base acute or abruptly acute, rugose and more or less undulate, midrib flat or slightly prominent and hirsute above, conspicuously prominent and densely hirsute beneath, nerves slender, slightly prominent and sparsely hirsute above, conspicuous and densely hirsute beneath, 10-13 pairs, ascending at an angle of $70-80^{\circ}$, curved to the margin, nervules obscure above, conspicuous beneath, reticulate; petioles c. $2 \mathrm{~mm}$ long, densely tomentose. Stipules subulate-triangular, 2-3 $\mathrm{mm}$ long, densely tomentose. Inflorescences axillary, sessile; bracts absent. Flowers fascicular, sessile; calyx $2 \mathrm{~mm}$ long, pubescent on the external surface, tube obconical, c. $1 \mathrm{~mm}$ long, limb campanulate, lobes 5 , triangular or subulate, c. 0.8 $\mathrm{mm}$ long; corolla up to $5 \mathrm{~mm}$ long, puberulous external surface, lobes 5, oblong-lanceolate, c. $2 \mathrm{~mm}$ long; stamens 5, filaments c. $0.8 \mathrm{~mm}$ long; anthers oblong, c. $0.8 \mathrm{~mm}$ long; ovary with 5 locules. Mature drupes not seen. Immature drupes subglobose, subglabrous, smooth; pyrenes 5 , smooth on the abaxial face.

Distribution - Endemic to Sumatra.

Habitat \& Ecology — Montane forest between 1100-1500 m altitude. Flowering and fruiting between February and June.

Additional specimens examined. N Sumatra, Atjeh, De Wilde et al. 14766 (K, L), 18625 (K, L).

Note - This species is similar to L. clementis, but differs from the latter by having densely tomentose hairs on branchlets; leaves oblong-lanceolate, rugose, undulate at margin, nerves $10-13$ pairs, nervules conspicuously reticulate; calyx with a campanulate limb. Lasianthus clementis has appressedpubescent branchlets; leaves ovate-lanceolate, smooth on surfaces and at margin; nerves 4-5 pairs; nervules subparallel; calyx without a campanulate limb.

\section{Lasianthus venosus Blume}

Lasianthus venosus Blume (1826-1827) 990; Miq. (1857) 323; (1869) 249; Bakh.f. (1965) 340. — Type: Blume s.n. (holo L, barcode L0000711), Java, Seriboe.

Lasianthus pterospermus Wight (1846) 510; King \& Gamble (1904) 125; Ridl. (1923a) 160; K.M.Wong (1989) 368, syn. nov. - Type: Kew Dist. 2929 (Griffith s.n.) (holo K; iso HUH), Peninsular Malaysia.

Lasianthus singalensis Miq. (1869) 247, syn. nov. - Type: Korthals s.n. (holo L, barcode L0057495; iso L, barcode L0057496), Sumatra, Mt Singalang. Lasianthus chinensis sensu King \& Gamble (1904) 124, p.p. quoad specimen King's collector 10100 (L).

Shrubs, up to $4 \mathrm{~m}$ high; branchlets terete, 2-2.5 $\mathrm{mm}$ diam, appressed-puberulous or glabrous, compressed in the youngest part and often dark-brown when dry. Leaves: blades oblong, elliptic-oblong or obovate-oblong, $12-16$ by $3-4.5 \mathrm{~cm}$, thinly coriaceous, glabrous above, appressed-pubescent hairs on midrib and nerves or glabrescent beneath, apex cuspidateacute or cuspidate-acuminate, base cuneate to subrounded, more or less asymmetric, midrib and nerves flat above, prominent beneath, nerves $9-12$ pairs, ascending at an angle of over $60^{\circ}$, curved to the margin, nervules distinct above, distinct and prominent beneath, subparallel; petioles $2-3 \mathrm{~mm}$ long, pubescent. Stipules large, oblong-lanceolate to triangular oblong, 6-8 or to $10 \mathrm{~mm}$ long, 3-4 mm broad, appressed-pubescent. Cymes sessile, bracts absent. Flowers sessile; calyx tube obconic, 1-1.5 mm long, sparsely pubescent, lobes $4-5$, lanceolate to triangular, 1-1.5 mm long, hirsute both sides; corolla tubular, c. $6 \mathrm{~mm}$ long, glabrous and dark outside, lobes $4-5$, ovate, c. $2 \mathrm{~mm}$ long. Drupes subglobose, 6-8 mm diam, glabrous, conspicuously and sharply 8-10-ridged, crowned by hirsute calyx limbs; pyrenes 4-5, 2-winged on the abaxial face.

Distribution - Malaysia (Peninsular, Sarawak), Indonesia (Sumatra, Kalimantan).

Notes - Lasianthus venosus is characterized by triangularoblong to oblong-lanceolate stipules up to $10 \mathrm{~mm}$ long, drupes sharply $8-10$-ridged with $4-5$ pyrenes, c. $8 \mathrm{~mm}$ diam, pyrenes with 2 wings (a longitudinal wing on each side of the convex of pyrene). Lasianthus pterospermus and L. singalensis are 


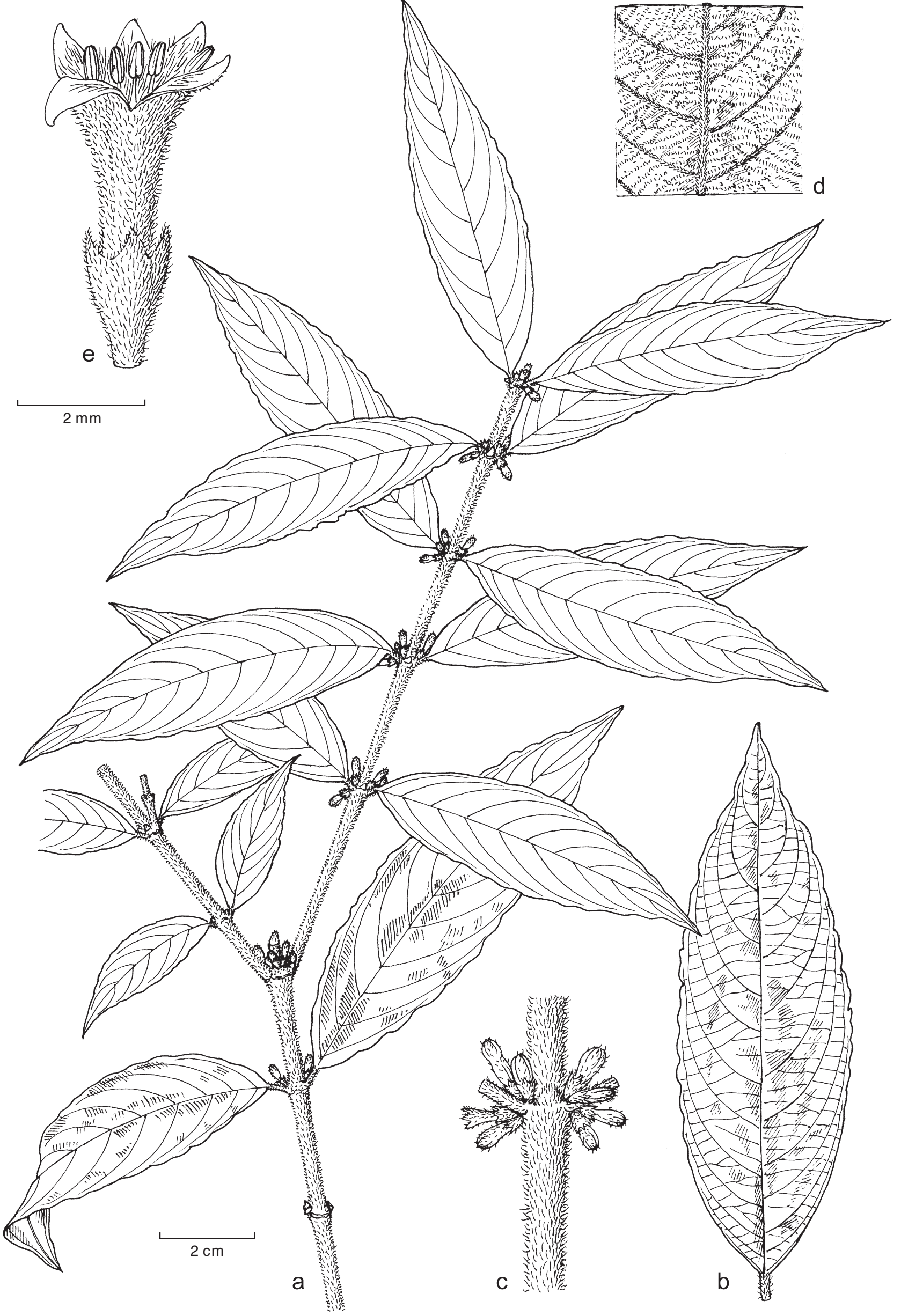

Fig. 39 Lasianthus undulatus H.Zhu. a. Habit with flowers; b. leaf showing reticulate nervules; c. detail of node showing stipule and axillary inflorescences; d. detail of lower surface of leaf showing indumentum; e. flower (all: Van Steenis 9886, holo L). 
characterized just by the same characteristics as $L$. venosus. They are surely conspecific.

Miquel (1869) reduced $L$. rigidus to a synonym of $L$. venosus. However, the type of $L$. rigidus is quite different from the type of $L$. venosus and represent a different species.

\section{Lasianthus verticillatus (Lour.) Merr. — Map 9}

Lasianthus verticillatus (Lour.) Merr. (1935) 372; H.Zhu (1994) 68; (1998) 156 (2001b) 144; (2002) 90. - Dasus verticillatus Lour. (1790) 142; S.Moore (1925) 250. - Type: Dausus G.48 (holo BM), Vietnam.

Lasianthus sylvestris Blume (1826-1827) 999; Miq. (1857) 323; (1869) 248; Bakh.f. (1965) 343, syn. nov. - Type: Blume s.n. (holo L, barcode L0057520), Java, Rompien.

Lasianthus sylvestris Blume var. subsessilis (Miq.) Miq. (1869) 248. — Lasianthus subsessilis Miq. (1861) 550, syn. nov. - Type: Teysmann 4273 (holo L; iso K), Sumatra, Lampong.

Lasianthus truncatus Bedd. (1874) 2, t. 9; Hook.f. (1880) 189; Deb \& M.Gangop. (1991) 302, f. 13. - Type: Beddome s.n. (lecto K, designated by Deb \& Gangopadhyay 1991), India, Mahendra Hill.

Lasianthus andamanicus Hook.f. (1880) 189; Deb \& M.Gangop. (1991) 276, excl. var. ciliatus Deb \& M.Gangop.; Craib (1934) 207. — Type: Wall. Cat. 8309 (holo K), Andaman.

Lasianthus wrayi King \& Gamble (1904) 119; Ridl. (1923a) 162, syn. nov. - Type: Wray 257 (holo K; iso U), Peninsular Malaysia, Perak, $4500 \mathrm{ft}$.

Lasianthus morus Elmer (1906a) 73; Merr. (1923) 567, syn. nov. — Type: Elmer 7050 (holo A; iso K, NY), Philippines, Palo, Leyte.

Lasianthus tamirensis Pierre ex Pit. (1924) 390. — Type: Pierre 587 (holo P; iso A, K, L, MO, SING), Cambodia, Samrong-tong, Mt Tamire.

Lasianthus nigrocarpus Masam. (1932) 222, nom. nud.

Lasianthus taitoensis Shimizu (1944) 239. — Lasianthus obliquinervis Merr. var. taitoensis (Shimizu) T.S.Liu \& J.M.Chao (1964) 145, f. 15; H.J.Li \& H.Y.Liu (1998) 293. - Lasianthus verticillatus (Lour.) Merr. var. taitoensis (Shimizu) H.Zhu (1994) 69; (1998) 156. - Type: Suzuki \& Fukuyama s.n. (TIU, n.v.), Taiwan.

Lasianthus obliquinervis auct. non Merr.: T.S.Liu \& J.M.Chao (1964) 141, f. 13; J.M.Chao (1978) 301; H.J.Li \& H.Y.Liu (1998) 293, pl. 132; H.S.Lo (1999) 100, pl. 26: 1-6.

[Lasianthus chinensis auct. non Benth.: Maxim. (1883) 173; A.Henry (1896) 51; Matsum. (1901) 16; Pit. (1924) 391; H.L.Li (1963) 855, p.p.].

Shrubs, $1.5-3 \mathrm{~m}$ tall; branchlets terete, c. $3 \mathrm{~mm}$ diam, appressed-pubescent. Leaves: blades oblong to oblong-lanceolate, $9-18$ by $1.5-7 \mathrm{~cm}$, coriaceous, glabrous above, thinly pubescent beneath, apex cuspidate-acute, acute or cuspidateacuminate, base acute, midrib and nerves flat or slightly prominent above, conspicuously prominent beneath, nerves 5-9 pairs, nervules densely anastomosing, parallel; petioles 5-10 mm long, pubescent. Stipules triangular, 3-4 mm long, pubescent. Cymes sessile; bracts absent or small subulate bracts; 2-5-flowered. Flowers sessile; calyx cupular, 3-5 mm long, subglabrous or puberulous, tube short, 1-2 mm long, limb 2-3 mm long, truncate or minutely dentate at apex, puberulous; corolla up to $10-12 \mathrm{~mm}$ long, hirsute outside, villous inside, lobes 5, ovate. Drupes subglobose, up to $10 \mathrm{~mm}$ diam, crowned by an enlarged cupular and truncate calyx limb, smooth on external surface; pyrenes usually 5 , rare 4 .

Distribution - India (Andaman and Nicobar Islands), Sri Lanka, Burma, China, Japan (Ryukyu), Vietnam, Laos, Cambodia, Thailand, Malaysia (Peninsular, Sabah), Philippines (Luzon to Palawan and Mindanao), Indonesia (Sumatra, Java, Lesser Sunda Islands, Sulawesi), Papua New Guinea.

Notes - Lasianthus verticillatus is a wide distributed and variable species. It was treated as $L$. andamanicus and, the form with narrow leaves, as $L$. truncatus in India and Burma, as $L$. sylvestris, with the form with narrow leaves as var. subsessilis in Java and Sumatra, as L. tamirensis in Cambodia. It was confused with $L$. obliquinervis in the Philippines and also confused with $L$. chinensis and $L$. trichophlebus in China and Indochina.
Lasianthus verticillatus differs from $L$. trichophlebus by having more or less appressed pubescence on branches and leaf nerves beneath, stipules usually shorter, c. $3 \mathrm{~mm}$ long, flowers usually 5-merous, calyx limb cupular and usually truncate or sometimes minutely toothed, as well as the drupes crowned by a cupular and truncate calyx limb and smooth on external surface.

The specimens from mainland southeast China, Taiwan and Ryukyu that have been treated as $L$. obliquinervis are clearly conspecific with $L$. verticillatus. That is why Zhu (1994) reduced $L$. obliquinervis to a synonym of the latter. After examining specimens indicated as $L$. obliquinervis from the Philippines in $\mathrm{K}, \mathrm{L}, \mathrm{MO}, \mathrm{SING}$, it is found that these specimens represent more than one Lasianthus species. Even specimens determined as $L$. obliquinervis by Merrill himself, represent more than one species. Most of them agree well with $L$. verticillatus, while some do not. When Merrill described L. obliquinervis, he cited 10 collections (syntypes). We have seen only one of them, i.e. Whitford?t 247, isosyntypes in P and US. The isosyntype represents a different species from $L$. verticillatus. According to Merrill, $L$. obliquinervis has oblong-ovate c. $5 \mathrm{~mm}$ long stipules, calyx limbs with 4-5 triangular lobes and drupes with 6 triquetrous pyrenes and not crowned by an enlarged cupular and truncate limbs, which do not agree with $L$. verticillatus.

Lasianthus sylvestris, from the type specimen, is the same species as $L$. verticillatus. Although variety subsessilis has narrower leaves, it is just the same as $L$. truncatus.

Lasianthus wrayi has branches densely appressed-pubescent; leaves oblong-lanceolate, appressed-pubescent on nerves beneath, nerves 5, nervules parallel; stipules triangular; inflorescences subsessile; calyx campanulate, appressed-hirsute, with 4 small acute teeth. The incomplete duplicate of type specimen in $U$ shows that $L$. wrayi is very similar to $L$. verticillatus. None of its characters are beyond the variability of $L$. verticillatus. It is, therefore, better to sink $L$. wrayi into $L$. verticillatus.

The specimens treated as $L$. morus were mixtures containing $L$. verticillatus, $L$. trichophlebus, and $L$. chlorocarpus. The type specimens of $L$. morus shows that this species has branchlets sparsely hirsute; leaves lanceolate, subcoriaceous, $10-16$ by $1.5-2.5 \mathrm{~cm}$, with falcate-caudate apex and acute or cuneate base, glabrous above, thinly appressed-pubescent venation beneath; stipules triangular, c. $2 \mathrm{~mm}$ long, hirsute; cymes sessile or very congested; calyx campanulate, pubescent, with a limb truncate or minutely 4-toothed; drupes verrucose, crowned by 4 minute subulate teeth, with 4 pyrenes. This species matches $L$. verticillatus and is here reduced to the latter.

Lasianthus verticillatus differs from $L$. chinensis by having usually thinner appressed-pubescent branches and leaf nerves beneath, coriaceous leaves with 5-9 pairs of nerves and parallel veinlets, cupulate and usually truncate calyx without teeth or sometime with minute teeth, and the drupes without conspicuous angular.

\section{Lasianthus vriesianus Miq.}

Lasianthus vriesianus Miq. (1869) 249. - Type: De Vriese \& Teysmann s.n. (holo L, barcode L0057506), Borneo.

Shrubs or treelets?; branchlets subterete, robust, c. $4.5 \mathrm{~mm}$ diam, glabrous, dark-brown when dry. Leaves: blades ovateoblong, $13-19$ by $4.5-6 \mathrm{~cm}$, coriaceous, glabrous on both surfaces, apex acuminate, base broadly cuneate to subrounded; midrib prominent above, strongly prominent and dark-brown in colour beneath, nerves prominent on both surfaces, 6-8 pairs, ascending at an angle of $70-80^{\circ}$, curved to the margin, nervules densely anastomosing, prominent and distinct on 
both surfaces, subparallel; petioles c. $1 \mathrm{~cm}$ long, glabrous. Stipules broadly triangular, c. $2 \mathrm{~mm}$ long, puberulous. Cymes tuberculate; bracts absent. Flowers shortly pediceled; pedicels 2-3 mm long, slender, glabrous; calyx very small, campanulate, c. $1 \mathrm{~mm}$ long, glabrous, with 4-5 triangular teeth; corolla not seen. Drupes globose, c. $3 \mathrm{~mm}$ diam, glabrous, with 4-5 obtuse ridges; pyrenes 4-5.

Distribution - Endemic to Borneo.

Note - This species is characterized by glabrous and large coriaceous leaves and pediceled flowers. It is closely related to $L$. brevipedicellatus by similar pediceled flowers and drupes, but differs from the latter by having thickly coriaceous leaves with subrounded base. Lasianthus brevipedicellatus has chartaceous to subcoriaceous leaves with acute base. Only the type specimen of $L$. vriesianus with few immature drupes is seen. Of $L$. brevipedicellatus, only the type specimen and a collection from Malaysia, both in fruiting stage, were studied.

\section{Lasianthus vulcanicus Ridl.}

Lasianthus vulcanicus Ridl. (1923b) 71. - Type: Ridley s.n. (holo K), Sumatra, Sibavak volcano.

Treelets, up to $5 \mathrm{~m}$ high; branchlets terete, c. $1.5 \mathrm{~mm}$ diam, glabrous or sparsely pubescent hairs on the youngest part. Leaves: blades ovate, ovate-elliptic or ovate-lanceolate, 5-10 by $1-3 \mathrm{~cm}$, coriaceous, glabrous on both surfaces, apex caudate, base acute, rarely acuminate, midrib, nerves and nervules distinct and prominent on both surfaces, nerves 5-7 pairs, usually ascending at an angle of over $60^{\circ}$, curved to the margin, nervules densely anastomosing, subparallel; petioles 4-5 mm long, glabrous or sparsely pubescent. Stipules triangular, 1.5-3 mm long, with a swollen base, glabrous or sparsely pubescent. Cymes sessile, bracts absent. Flowers sessile; calyx tube obconic, $0.8-1 \mathrm{~mm}$ long, glabrous, limb cupular, c. $1 \mathrm{~mm}$ long, minutely 5-toothed; corolla short, 3-4 $\mathrm{mm}$ long, glabrous outside. Drupes obconic-globose, 3-4 mm diam, glabrous; pyrenes 4-5.

Distribution - Malaysia (Sabah), Indonesia (Sumatra, Java).

Note - This species is quite close to L. stercorarius, but differs from the latter by having glabrous branchlets and leaves, leaves with caudate apex, nervules distinct on both surfaces, densely anastomosing, parallel, relatively short petioles, stipules relatively small, calyx with a shortly cupular limb and drupes with 4-5 pyrenes.

\section{Lasianthus wightianus Hook.f.}

Lasianthus wightianus Hook.f. (1880) 188; King \& Gamble (1904) 125; Ridl. (1923a) 162. - Type: Kew Dist. 2922 (Griffith s.n.) (holo K), Peninsular Malaysia, Mt Ophir.

Lasianthus venosus auct. non Blume: Wight (1846) 514

Shrubs, up to $2.5 \mathrm{~m}$ high; branchlets robust, subterete, 2.5-3 $\mathrm{mm}$ diam, brown-tomentose. Leaves: blades oblong or lanceolate oblong, $4-10$ by $1.5-3.5 \mathrm{~cm}$, rigid-chartaceous, scaberulous or tomentose hairs on midrib and nerves both surfaces, densely beneath, apex acuminate, base acute to subrounded, midrib and nerves slender and flat above, stout and prominent beneath, nerves $9-13$ pairs, ascending at an angle of over $50^{\circ}$, curved to the margin, nervules prominent on both surfaces, conspicuously reticulate; petioles c. $2 \mathrm{~mm}$ long, tomentose. Stipules conspicuous, broadly triangular, 3-4 mm long, pubescent. Cymes sessile; bracts absent. Flowers sessile; calyx campanulate, pubescent, tube $0.8-1 \mathrm{~mm}$ long, lobes 5 , subulate-triangular, c. $1 \mathrm{~mm}$ long; corolla hirsute outside. Drupes ellipsoid, glabrous or pubescent, c. $3 \mathrm{~mm}$ diam; pyrenes 4-5.

Distribution - Endemic to Peninsular Malaysia.
Note - This species is closely related to L. malaccensis by its leaves with conspicuously reticulate nervules, but differs from the latter by having densely pubescent branchlets, pubescent midrib and nerves on both surface; nerves 9-13 pairs; petioles $2 \mathrm{~mm}$ long; stipules relatively big; drupes with 5-6 pyrenes. Lasianthus malaccensis has young branchlets puberulous and later glabrescent, midrib and nerves minutely appressed puberulous beneath; nerves 8-9 pairs; petioles 5-6 mm long; stipules relatively small; drupes with 4 pyrenes.

\section{DUBIOUS SPECIES}

1. Lasianthus apiocarpus (Korth.) Miq. (1857) 318. - Mephitidia apiocarpa Korth. (1851) 221. - Type: Korthals s.n. (n.v.), Sumatra, Singalang,

Note - According to Korthals' description, this species has oblong leaves; tomentose branches and leaves beneath as well as petioles; lanceolate bracts; glabrous pyriform drupes. This species seems to be quite closely related to $L$. ellipticus except for its glabrous drupes (L. ellipticus has hirsute drupes). However, after all collections in L were checked, no Korthals' collection that matches the description was found. Also Miquel did not see Korthals' material with the name Mephitidia apiocarpa. There is not enough evidence to confirm that $L$. apiocarpus is conspecific with L. ellipticus.

2. Lasianthus brevipes Valeton (1927) 110. - Syntypes: Ledermann 9303 (L), 10310 (L), New Guinea.

Note - This species does not match Lasianthus in having 2-pyrened drupes with a thin wall. Its generic position needs to be further studied.

3. Lasianthus caudiculatus Ridl. (1915) 48; (1923a) 167. - Type: Robinson s.n. (holo K), Peninsular Malaysia, Perak, $4500 \mathrm{ft}$. Note - According to Ridley's description L. caudiculatus has yellow appressed hairs on branches, leaf nerves beneath; leaves lanceolate with long caudate apex and cuneate base, $8-9$ by $2.5 \mathrm{~cm}$; nerves 5 pairs; stipules triangular, silky; cymes sessile; calyx covered by silky yellow hairs. We have not seen any specimen from Peninsular Malaysia that matches Ridley's description. Wong (1989) reduced it to a synonym of L. montanus. However, L. montanus is quite ambiguous because no other confirming specimens are available except the imperfect type specimen in SING. The few specimens indicated as L. montanus actually belong to Urophyllum hirsutum Wight.

4. Lasianthus furcatus (Miq.) Bremek. (1957) 94, in adnot. Canthium furcatum Miq. (1857) 252. — Syntypes: Junghuhn s.n. L0000682 (L), Junghuhn s.n. L0000683 (L), Java, Oengaran, Pengalengan; Zollinger s.n. (n.v.), Java, Gede.

Note - This species does not match Lasianthus in having 2-pyrened drupes with a thin wall. Its generic position needs to be further study.

5. Lasianthus harveyanus King \& Gamble (1904) 129; Ridl. (1923a) 162; K.M.Wong (1989) 370. - Type: Wray 444 (n.v.), Peninsular Malaysia, Perak, $3400 \mathrm{ft}$.

Note - From King \& Gamble's description, this species has branches rather thick and minutely rusty-tomentose; leaves membranaceous, elliptic or ovate-elliptic, 4-5 in. long, apex rather blunt, base rounded, scabrid-puberulous beneath, nerves 4-6, minutely pubescent beneath, rusty-tomentose on the midribs on both sides; stipules triangular; cymes sessile, ebracteate; flowers sessile, 4-merous, calyx narrowly campanulate, densely pubescent, mouth 4-toothed. No specimens which match the species were found. 
6. Lasianthus harveyanus King \& Gamble var. longifolia King \& Gamble (1904) 129; Ridl. (1923a) 161. - Type: Harvey s.n. (n.v.), Peninsular Malaysia.

Notes - From King \& Gamble's description, this variety has relatively large oblong-elliptic leaves with acuminate apex and 8-9 pairs of nerves up to $7.5 \mathrm{in}$. long.

Wong (1988) mentioned that only type collections of $L$. harveyanus and var. longifolia were known and informed us that they should be in SING. However, we did not see them in SING. No specimen checked by us match King \& Gamble's descriptions well. Therefore we treat both this species and its variety as dubious.

7. Lasianthus lowianus King \& Gamble (1909) 871. — Lasianthus lucidus King \& Gamble (1904) 132, non Blume (18261827). - Syntypes: Ridley 7437 (SING); Wray 2807 (SING); King's collector 2840 (lecto L, designated here), Peninsular Malaysia, Selangor.

Note - This species does not match Lasianthus in having 2-pyrened drupes with a thin wall. Its generic position needs further study.

8. Lasianthus montanus King \& Gamble (1904) 127; Ridl. (1923a) 163; K.M.Wong (1989) 371. - Type: Wray 3932 (lecto SING, designated by Wong 1988), Peninsular Malaysia.

Note - This species is known from the incomplete type specimen in SING only. Since ovary and drupes were not included in King \& Gamble's description, we cannot be certain that the species belongs to Lasianthus.

9. Lasianthus ovatus (Korth.) Miq. (1857) 321. - Mephitidia ovata Korth. (1851) 221. - Type: Korthals s.n. (n.v.), Sumatra, Merapi.

Lasianthus ovatus (Korth.) Miq. var. oligoneurus (Korth.) Boerl. (1891) 141. - Mephitidia ovata Korth. var. oligoneura Korth. (1851) 221. - Type: Korthals s.n. (n.v.), Borneo, Sakoembang.

Notes - From Korthals' description, this species has oblongovate leaf blade, apex acuminate, base obtuse or subcordate, hirsute beneath; cymes capitulate, with hirsute peduncle. According to the original description, this species differs from $L$. capitatus by having curved nerves, prolonged nervules, shorter calyx lobes.

Miquel did not see the type specimens. Neither did we after checking all Lasianthus collections in L. Several specimens from Sumatra and Borneo roughly match Korthals' simple description, however, not one of these specimens can with certainty be identified with $L$. ovatus.

10. Lasianthus platyphyllus (Korth.) Miq. (1857) 318. - Mephitidia platyphylla Korth. (1851) 222. - Type: Korthals s.n. (n.v.), Sumatra, Singalang.

Note - According to Korthals, this species has branches glabrous; leaves ovate, the apex short acuminate, the base acute, nerves parallel, strigose beneath; bracts lanceolate, strigose; calyx lobes lanceolate hirsute. No specimens from Sumatra were found to match Korthals' description.

11. Lasianthus rufus (Korth.) Miq. (1857) 325. - Mephitidia rufa Korth. (1851) 222. — Type: Korthals s.n. (n.v.), Java, Boerangrang.

Note - According to Korthals' description, this species has oblong-ovate and hirsute leaves with acuminate apex and unequal base; stipules ovate with acute apex, hirsute; calyx and drupes hirsute. There are no specimens from Java and Sumatra, which match the description of this species. However, as mentioned in the introduction, it is often a pitfall to recognise species without checking the type(s). These specimens from
Java and Sumatra also agree well with $L$. hirtus from Peninsular Malaysia. Lasianthus hirtus could be conspecific with L. rufus. However, as long as the type specimens of $L$. rufus are not found, it is better to keep the name $L$. hirtus and treat $L$. rufus as a dubious name.

12. Lasianthus stipularis Blume var. hirtus Ridl. (1923a) 153; K.M. Wong (1989) 370. - Type: Ridley s.n. (n.v.), Selangor, Limestone rock, Kanching.

Note - From Ridley's description, this variety has very hairy stems, leaf lower surface and stipules. No specimens which match Ridley's description were found.

\section{EXCLUDED SPECIES}

Lasianthus culionensis Elmer (1906b) 11. - Type: Merrill 615 (iso NY, n.v.), Philippines, Palawan, Culion. - Plectronia culionensis Merr. (1923) 535. = Canthium culionensis (Elmer) Merr. (1928) 8.

Lasianthus firmus Miq. (1861) 549. - Type: Teysmann s.n. (U), Sumatra, Palembang.

Note - From Miquel's description and type specimen, this species has large triangular-lanceolate stipules $1.5 \mathrm{~cm}$ long, coriaceous oblong leaves with 14-16 pairs of nerves, linear and appressed villose, bracteoles, and appressed villose calyx. No flowers and drupes were seen from the type specimen in $U$. From the stipule and leaf characters, it is not a Lasianthus.

Lasianthus hispidus Elmer (1906b) 10. — Type: E.D. Merrill 767 (iso K, NY), Philippines, Palawan, Paragua, $1700 \mathrm{ft}, 18$ Feb. 1903. = Hedyotis perhispida (Elmer) Elmer (1912) 1333.

Lasianthus leucocarpus (K.Schum. \& Lauterb.) M.Gangop. \& Chakrab. (1992) 338. - Litosanthes leucocarpa K.Schum. \& Lauterb. (in Lauterbach \& Schumann 1901) 586. - Type: Lauterbach 2113 (n.v.), New Guinea. = Amaracarpus grandifolius var. leucocarpus (Lauterb. \& K.Schum.) A.P.Davis (in Davis \& Bridson 2004) 46.

Lasianthus minahassae Koord. (1898) 496. = Praravinia minahassae Koord. (1904) 79; (1922) 60.

Lasianthus multibracteatus Wernham (1916) 78. - Type: Boden-Kloss s.n. (holo BM), New Guinea 3900 ft ? = Amaracarpus.

Note - According to Wernham's description, this species has deciduous, $1.5 \mathrm{~cm}$ long stipules and a bilocular ovary, which suggest that it is not a Lasianthus species.

Lasianthus novoguineensis (Warb. ex Boerl.) M.Gangop. \& Chakrab. (1992) 338. - Litosanthes novoguineensis Warb. ex Boerl. (1891) 142. = Amaracarpus novoguineensis (Warb. ex Boerl.) Valeton (1911) 501.

Lasianthus subspicatus King \& Gamble (1904) 118; Ridl. (1923a) 168. - Syntypes: Curtis 4276 (SING), Peninsular Malaysia, Penang; Wray 863 (n.v.), Perak. = Hypobathrum Iongifolium (DC.) K.M.Wong (1989) 354.

Lasianthus tobingensis Miq. (1869) 249. - Type: Junghuhn s.n. (holo L, barcode L0000729; iso U), Sumatra, Tobing. = Leucolophus tobingensis (Miq.) Bremek. (1940) 189.

Lasianthus villosus Ridl. (1918) 86; (1923b) 168. - Type: Ridley 14074 (K), Peninsular Malaysia, Perak, Tapah. = Urophyllum.

Note - This species has leaves elliptic with a long-caudate apex and obtuse base; nerves 18 pairs; stipules lanceolate with acuminate apex, up to $1.5 \mathrm{~cm}$ long, villous; cymes stout with 
$5 \mathrm{~mm}$ long peduncles, bracts lanceolate, 4-7 mm long; Fruits hairy, with numerous small seeds. It is clearly a Urophyllum.

Litosanthes brauniana Warb. ex Boerl. (1891) 142. - Lasianthus braunianus (Warb. ex Boerl.) M.Gangop. \& Chakrab. (1992) 338. = Amaracarpus braunianus (Warb. ex Boerl.) Valeton (1911) 501.

Acknowledgements This research was supported by a grant from NWO of the Netherlands (grant no. B 85-340) and grants of the National Natural Science Foundation of China (No. 30770158, 31170195, 41071040). We thank the Herbaria AAU, BK, BKF, BM, C, E, HBG, K, KEP, L, MO, NY, P, SING, U, US for checking specimens and loan of type specimens. We are grateful to Prof. P. Baas, Dr. F. Adema, Prof. P.C. van Welzen and Dr. W.J.J.O. de Wilde (all L) for their great help in the research, and to Dr. J.F. Veldkamp (L) for his great help in botanical nomenclature. We thank Mr. Wu Xilin, a botanical artist of the herbarium of Kunming Institute of Botany, the Chinese Academy of Sciences for illustrations in the article. We also thank reviewers and editors very much for their important and constructive comments.

\section{REFERENCES}

Andersson L, Rova JHE. 1999. The rps16 intron and the phylogeny of the Rubioideae (Rubiaceae). Plant Systematics and Evolution 214: 161-186. Baillon H. 1880. Histoire des plantes 7: 546. Hachette, Paris.

Bakhuizen van den Brink Jr RC. 1963. Notes on the flora of Java VIII. Blumea 12: 63-64.

Bakhuizen van den Brink Jr RC. 1965. Lasianthus Jack. In: Backer CA, Bakhuizen van den Brink Jr RC (eds), Flora of Java 2: 334-343. Groningen, Noordhoff.

Beddome RH. 1874. Icones Plantarum Indiae Orientalis 1: 2, t. 8. Gantz Brothers, Madras.

Bentham G. 1861. Flora Hongkongensis: 160-161. Reeve \& Co. Ltd., London. Blume CL. 1823. Catalogus Gewassen Buitenzorg: 51.

Blume CL. 1826-1827. Bijdragen Flora Nederlandsch Indie: 994-1001. Ter Lands Drukkerij, Batavia.

Boerlage JG. 1891. Handleiding Flora van Nederlandsch Indie: 140-142. Brill, Leiden.

Bremekamp CEB. 1940. On Urophyllum Wall. (Rubiaceae) and its nearest allies. Recueil des Travaux Botaniques Néerlandais 37: 189.

Bremekamp CEB. 1957. Monographie du genre Saldinia A. Rich. (Rubiaceae). Candollea 16: 91-129.

Bremer B. 1996. Phylogenetic studies within Rubiaceae and relationships to other families based on molecular data. Opera Botanica Belgica 7: 33-50.

Bremer B, Manen JF. 2000. Phylogeny and classification of the subfamily Rubioideae (Rubiaceae). Plant Systematics and Evolution 225: 43-72.

Cai ZQ, Rijkers T, Bongers F. 2005. Photosynthetic acclimation to light changes in tropical monsoon forest woody species differing in adult stature. Tree Physiology 25: 1023-1031.

Champion JG. 1852. Florula Hongkongensis. Kew Journal of Botany 4: 196. Chao JM. 1978. Lasianthus. Flora of Taiwan 4: 282-305.

Craib WG. 1933. Contributions to the Flora of Siam. Add. 38. Kew Bulletin 1933: $18-30$.

Craib WG. 1934. Lasianthus. Flora of Siamensis Enumeratio 2, 1: 207-220. The Bangkok Times Press, Bangkok.

Davis AP, Bridson DM. 2004. A taxonomic revision of the genus Amaracarpus (Rubiaceae, Psychotrieae). Blumea 49: 25-68.

De Candolle AP. 1830. Rubiaceae. Prodromus 4: 452-453.

Deb DB, Gangopadhyay M. 1987. New taxa of the genus Lasianthus (Rubiaceae). Journal of the Bombay Natural History Society 84: 458-462.

Deb DB, Gangopadhyay M. 1989. Review of the genus Litosanthes Blume. (Rubiaceae). Candollea 44: 200-223.

Deb DB, Gangopadhyay M. 1991. Taxonomic study of the genus Lasianthus Jack (Rubiaceae) in India. Journal of Economic and Taxonomic Botany 15, 2: 265-308.

Denys E. 1981. Les Lasianthus Jack (Rubiaceae) du Zaire, du Rwanda et du Burundi. Bulletin du Jardin Botanique National de Belgique 51: 445-456. Drake M. 1895. Contribution à la Flore du Tonkin. Journal of Botany 9: $238-240$.

Elmer ADE. 1906a. Additional new species of Rubiaceae. Leaflets of Philippine Botany 1: 73.

Elmer ADE. 1906b. Philippine Rubiaceae. Leaflets of Philippine Botany 1: $9-12$.

Elmer ADE. 1908. Three score of new plants. Leaflets of Philippine Botany 2: $519-520$.
Elmer ADE. 1911. New and noteworthy Rubiaceae. Leaflets of Philippine Botany 3: 1034-1035.

Elmer ADE. 1912. Palawan Rubiaceae. Leaflets of Philippine Botany 4: 1333. Elmer ADE. 1913. Rubiaceae from Mount Urdaneta. Leaflets of Philippine Botany 5: 1869-1973.

Elmer ADE. 1934a. New Urticaceae and Rubiaceae. Leaflets of Philippine Botany 9: 3252-3253.

Elmer ADE. 1934b. New plants from Mount Pinatubo. Leaflets of Philippine Botany 9: 3209-3210.

Forbes FB, Hemsley WB. 1888. An enumeration of all the plants known from China proper, Formosa, Hainan, Corea, the Luchu Archipelago and the Islands of Hongkong, together with their distribution and synonymy. Journal of the Linnean Society (Botany) 23: 388.

Gangopadhyay M, Chakrabarty T. 1992. A note on the status of Lithosanthes BI. (Rubiaceae). Journal of Economic and Taxonomic Botany 16: 337-338. Gibbs MLS. 1914. A contribution to the flora and plant formations of Mount Kinabalu and the highlands of British North Borneo. Journal of the Linnean Society (Botany) 42: 95.

Hance HF. 1875. Two additions to the Hongkong flora. Journal of Botany 4: 196.

Hance HF. 1885. Spicilegia florae sinensis: diagnoses of new and habitats of rare or hitherto unrecorded, Chinese plants. Journal of Botany 23: 324. Hara H, Gould S. 1979. An Enumeration of the Flowering Plants of Nepal 2: 204.

Hayata B. 1912. Icones Plantarum Formosarum 2: 113. Taihoku, Tokyo. Hayata B. 1919. Icones Plantarum Formosarum 9: 62-64. Taihoku, Tokyo. Henderson MR. 1933. Additions to the flora of the Malay peninsula. Garden's Bulletin Singapore 7: 107.

Henry A.1896. A list of plants from Formosa: 51

Hemsley WB. 1888. Journal of the Linnean Society, Botany 23, 156: 388-389. Hiern WP. 1877. In: Oliver D, Flora of Tropical Africa 3: 228.

Hooker JD. 1873. In: Bentham G, Hooker JD, Genera Plantarum 2: 129

Hooker JD. 1880. Flora of British India 3: 178-192. London, Reeve \& Co. Ltd. Igersheim A, Robbrecht E. 1993. The character states and relationships of the Prismatomerideae (Rubiaceae-Rubioideae). Comparison with Morinda and comments on the circumscription of the Morindeae s.s. Opera Botanica Belgica 6: 61-79.

Jack W. 1823. Account of the Lansium and some other genera of Malayan plants. Transactions of the Linnean Society of London 14: 125-126.

Kanehira R. 1936. Formosan trees: 669. Department of Forestry, Government Research Institute, Formosa.

King G, Gamble JS. 1904. Materials for a flora of the Malayan Peninsula - Lasianthus Jack. Journal of the Asiatic Society of Bengal 73: 106-133.

King G, Gamble JS. 1909. Materials for a flora of the Malayan Peninsula Addend.-Corrig. Journal of the Asiatic Society of Bengal 74: 871.

Koorders SH. 1898. Flora van N.O. Celebes: 496. Kolff \& Co., Batavia.

Koorders SH. 1904. Zweiter Nachtrag zur Enumeratio specierum Phanerogamarum minahassae. Natuurkundig Tijdschrift voor Nederlandsch Indië 63: 79.

Koorders SH. 1922. Supplement Flora van N.O. Celebes III: 60. Van Visser \& Co., Batavia.

Korthals PW. 1851. Rubiaceae. Nederlandsch Kruidkundig Archief 2: 217-224.

Kuntze O. 1891. Revisio generum plantarum: 290. Felix, Leipzig.

Kurz WS. 1875. Descriptions of new plants from Nicobar Islands. Journal of Botany 4: 327.

Kurz WS. 1877. Forest Flora of British Burma 2: 8-49. Office of Superintendent of Government Printing, Calcutta.

Lauterbach CAG. 1905. Lasianthus. In: Schumann K, Lauterbach K, Nachträge Flora Deutschen Schutzgebiete Südsee: 399-400. Leipzig, Borntraeger.

Lauterbach CAG, Schumann KM. 1901. Die Flora der Deutschen Schutzgebiete in der Südsee: 586 .

Li HJ, Liu HY. 1998. Lasianthus Jack. Flora of Taiwan, 2nd ed. 4: 276-296.

Li HL. 1943. Journal of Arnold Arboretum 24, 4: 457-458.

Li HL. 1944. Notes on the Flora of southern China. Journal of Arnold Arboretum 25: 430 .

Li HL. 1963. Woody Flora of Taiwan: 854-859. Livingston Publishing Co., Narberth, Pennsylvania.

Liu TS, Chao JM. 1964. Revision of the Taiwan species of Lasianthus (Rubiaceae). Taiwania 10: 118-149.

Lo HS. 1993. Materials for Chinese Rubiaceae (III). Botanical Journal of South China 1: 1-17.

Lo HS. 1999. Rubiaceae. Flora of Reipublicae Popularis Sinicae 71, 2: 70106.

Loureiro J. 1790. Flora Cochinchinensis: 142. Berolini.

Masamune G. 1932. Transactions of the Natural History Society of Taiwan 22: 222. 
Masamune G. 1934. Beiträge zur Kenntnis der Flora von Südjapan II. Transactions of the Natural History Society of Formosa 24: 211.

Matsumura J. 1901. Notulae ad Plantae Asiaticas Orientales. The Botanical Magazine Tokyo 15: 16-17, 37

Maximowicz CJ. 1883. Diagnoses plantarum novarum asiaticarum. Bulletin de l'Académie impériale des sciences de St.-Pétersbourg 29: 173.

McNeill J, Barrie FR, Burdet HM, Demoulin V, Hawksworth DL, Marhold K, Nicolson DH, Prado J, Silva PC, Skog JE, Wiersema JH, Turland NJ. 2006. International code of botanical nomenclature (Vienna Code). Gartner Verlag KG.

Merrill ED. 1906. The flora of the Lamao Forest Reserve. The Philippine Journal of Science 1, suppl.: 136

Merrill ED. 1907. The flora of Mount Halcon, Mindoro. The Philippine Journal of Science 2: 306

Merrill ED. 1908a. New or noteworthy Philippine plants VI. The Philippine Journal of Science 3: 265

Merrill ED. 1908b. New Philippine plants. The Philippine Journal of Science 3: 164.

Merrill ED. 1921. A bibliographic enumeration of Bornean plants. Journal of the Straits Branch of the Royal Asiatic Society, Special number 1921: 577-579.

Merrill ED. 1922. Noteworthy Philippine plants XVII. The Philippine Journal of Science 20: 432, 466-467.

Merrill ED. 1923. An enumeration of Philippine flowering plants 3: 535, 565-567. Manila, Bureau of Printing.

Merrill ED. 1928. The Philippine Journal of Science 35: 8.

Merrill ED. 1929a. Plantae Elmerianae Borneenses. Publication in Botany 15: 292-294. University of California.

Merrill ED. 1929b. Lingnan Science Journal 7: 323-324.

Merrill ED. 1935. A commentary on Loureiros's "Flora Cochinchinensis". Transactions of the American Philosophical Society, New series 24: 372.

Merrill ED. 1937. Rubiaceae. Mitteilungen aus dem Institut für allgemeine Botanik in Hamburg 7: 298-299.

Merrill ED. 1952. William Jack's genera and species of Malaysian plants. Journal of the Arnold Arboretum 33, 3: 199-230.

Merrill ED, Perry LM. 1946. Plantae Papuanae Archboldianae. Journal of Arnold Arboretum 27: 219

Miquel FAW. 1857. Flora Indiae Batavae 2: 252, 314-325. Van der Post Jr., Utrecht, Amsterdam; Fleischer, Leipzig.

Miquel FAW. 1861. Flora Indiae Batavae. Suppl.: 549-551. Van der Post Jr., Utrecht, Amsterdam; Fleischer, Leipzig.

Miquel FAW. 1869. Ecloge Rubiacearum Archipelagi Indici. Annales Musei Botanici Lugduno-Batavi 4: 245-249.

Moore S. 1925. Identification of Loureiro's specimens in the British Museum Herbarium. Journal of Botany, British and Foreign 63: 250.

Nakai T. 1922. Trees and shrubs of Japan, ed. 1: 396

Nakai T. 1927. Trees and shrubs of Japan, rev. ed.: 529.

Petit E. 1964. Les espèces africaines du genre Psychotria L. (Rubiaceae) I. Bulletin van den Rijksplantentuin, Brussel 34: 1-228.

Piesschaert F. 2001. Carpology and pollen morphology of the Psychotrieae (Rubiaceae-Rubioideae), PhD thesis, unpublished manuscript.

Piesschaert F, Anderson L, Jansen S, Dessein S, Robbrecht E, Smets E. 2000. Searching for the taxonomic position of the African genus Colletoecema (Rubiaceae): morphology and anatomy compared to an rps 16-intron analysis of Rubioideae. Canadian Journal of Botany 78: 288-304.

Pitard J. 1924. Rubiaceae. In: Lecomte H (ed), Flore Generale L'Indo-Chine 3, 3: 371-399. Paris, Masson \& Cie.

Prain D. 1903. Bengal plants: 576.

Reinwardt CGC. 1825. Rubiaceae. Sylloge Plantarum Novarum 2: 9.

Ridley HN. 1909. The flora of the Telôm and Batang Padang valleys. Journal of the Federated Malay States Museums 4: 35-37.

Ridley HN. 1910. A scientific expedition to Temengoh. Journal of the Straits Branch of the Royal Asiatic Society 57: 58-59.

Ridley HN. 1911. Journal of the Straits Branch of the Royal Asiatic Society 57: 60 .

Ridley HN. 1915. Journal of the Federated Malay States Museums 6: 48.

Ridley HN. 1912. New and rare Malayan plants. Journal of the Straits Branch of the Royal Asiatic Society 61: 23.

Ridley HN. 1915. Journal of the Federated Malay States Museums 6: 154

Ridley HN. 1917a. Lasianthus barbellatus, a new species from Pulau Tiuman, Pahang. Journal of the Straits Branch of the Royal Asiatic Society 77: 187.

Ridley HN. 1917b. Expedition to Korinchi. Journal of the Federal Malay States Museum 8: 52.

Ridley HN. 1918. New and rare Malayan plants X. Journal of the Straits Branch of the Royal Asiatic Society 79: 85-86.

Ridley HN. 1920. New and rare plants from the Malay Peninsula. Journal of the Federal Malay States Museum 10: 143-144
Ridley HN. 1923a. The Flora of the Malay Peninsula 2: 149-169. Reeve \& Co. Ltd., London.

Ridley HN. 1923b. A botanical excursion to northern Sumatra. Journal of the Malaysian Branch of the Royal Asiatic Society (Malayan Branch of the Royal Asiatic Society) 1: 71.

Ridley HN. 1934. Contribution towards a flora of British North Borneo IV. Kew Bulletin 1934 (1934) 120.

Ridsdale CE. 1998. Rubiaceae. In: Dassanayake MD, Clayton WD (eds), A revised handbook to the Flora of Ceylon vol. XII: 309-320. Balkema Publishers, Rotterdam.

Robbrecht E. 1982. The identity of the Panamanian genus Dressleriopsis (Rubiaceae). Annals of the Missouri Botanical Garden 69: 427-429.

Robbrecht E. 1988. Tropical woody Rubiaceae. Opera Botanica Belgica 1: 132.

Robbrecht E. 1993. Supplement to the 1988 outline of the classification of the Rubiaceae index to genera. Opera Botanica Belgica 6: 173-196.

Robbrecht E, Manen JF. 2006. The major evolutionary lineages of the coffee family (Rubiaceae, angiosperms). Combined analysis (nDNA and cpDNA) to infer the position of Coptosapelta and Luculia, and super tree construction based on rbcL, rps16, trnL-trnF, and atpB-rbcL data. A new classification in two subfamilies, Cinchonoideae and Rubioideae. Systematics and Geography of Plants 76: 85-146.

Roxburgh W. 1824. Descriptions of Indian plants 2: 180, 187

Sasaki S. 1928. List of plants of Formosa: 382.

Savi G. 1799. Mem. Soc. Ital. Modena 8: 479.

Schumann K. 1891. Rubiaceae. In: Engler A, Prantl K (eds), Die natürlichen Pflanzenfamilien. 4, 4: 1-156. Engelmann, Leipzig.

Schumann K. 1902. Rubiaceae. In: Schmidt J, Flora of Koh Chang. Botanisk Tidskrift 24: 339.

Schumann K. 1905. Rubiaceae. In: Schumann K, Lauterbach K, Nachträge Flora Deutschen Schutzgebiete Südsee: 399-400. Leipzig, Borntraeger. Shimizu D. 1944. Transactions Natural History Society Formosa 34: 238-239, 300-302.

Sprengel CPJ. 1830. Genera Plantarum: 94.

Stafleu FA, Cowan RS. 1979. Taxonomic literature - a selective guide to botanical publications and collections with dates, commentaries and types. Vol. 2, H-Le: 487. Bohn, Schletema \& Holkema, Utrecht \& Junk, The Hague.

Stapf O. 1894. On the flora of Mount Kinabalu in north Borneo. The Transactions of the Linnean Society of London 4: 96-263.

Valeton T. 1911. Rubiaceae. In: Lorenz HA (ed), Résultats de l'expédition scientifque néerlandaise à la Nouvelle-Guinée en 1907 et 1909, vol. 8, Botanique: 496-503.

Valeton T. 1914. Lasianthus glaber Scheff. In: Icones Bogorienses 4: 293, t. 400. Leiden.

Valeton T. 1927. Die Rubiaceae von Papuasien. II. Botanische Jahrbücher für Systematik 61: 105-111.

Valeton T, Winkler K. 1910. Beiträge zur Kenntnis der Flora und Pflanzengeographie von Borneo I. Botanische Jahrbücher für Systematik 44: 569. Van Steenis CGGJ. 1950. The delimitation of Malaysia and its main plant geographical divisions. Flora Malesiana, Ser. I, 1: Ixx-Ixxv.

Van Welzen PC, Slik JWF. 2009. Patterns in species richness and composition of plant families in the Malay Archipelago. Blumea 54: 166-171.

Verdcourt B. 1976. Rubiaceae (part 1). In: Pohill RM (ed), Flora of Tropical East Africa: 134-145. Agents for Oversea Governments and Administration, London.

Wernham HF. 1914. A contribution to the flora and plant formations of Mount Kinabalu and the highlands of British North Borneo. Journal of the Linnean Society (Botany) 42: 94.

Wernham HF. 1916. Rubiaceae. In: Ridley HN, Report on the botany of the Wollaston expedition to Dutch New Guinea, 1912-1913. Transactions of the Linnean Society of London, Second Series, Botany 9: 78.

Wernham HF. 1918. Dr. H.O. Forbes's New Guinea Rubiaceae I. Journal of Botany 56: 72-73.

Wight R. 1846. Notes on Indian Botany. Calcutta Journal of Natural History 6: 494-518.

Wight R, Walker-Arnott GA. 1834. Prodromus Florae Peninsulae Indiae Orientalis 1: $390,422$.

Winkler H. 1910. Botanische Jahrbücher für Systematik, Pflanzengeschichte und Pflanzengeographie 44: 569.

Wong KM. 1988. The arborescent Rubiaceae of Malaya: A manual of trees of Malayan Rubiaceae: 1-245. Forestry Department.

Wong KM. 1989. Rubiaceae. In: Ng FSP, Tree Flora of Malaya 4: 354, 367373. Malaysia, Longman.

Wu ZY. 1984. Index Florae Yunnanensis: 1259. Yunnan People's Press, Kunming. 
Xiao LQ, Zhu H. 2007. Paraphyly and phylogenetic relationship in Lasianthus (Rubiaceae) inferred from chloroplast rps16 data. Botanical Studies 48: 227-232.

Yamazaki T. 1964. Note on Lasianthus in Ryukyu. Journal of Japanese Botany 39: 348-352.

Zhu H. 1994. A taxonomic study on the genus Lasianthus Jack in China. Acta Phytotaxonomica Sinica 32: 49-81.

Zhu H. 1998. Notes on the genus Lasianthus Jack (Rubiaceae) from Asia. Acta Botanica Yunnanica 20: 149-159.
Zhu H. 2000a. A new species of Lasianthus (Rubiaceae) from Peninsular Malaysia. Garden's Bulletin Singapore 52: 257-259.

Zhu H. 2000b. New plants of the genus Lasianthus (Rubiaceae) from Vietnam. Acta Botanica Yunnanica 22: 398.

Zhu H. 2001a. New plants of Lasianthus Jack (Rubiaceae) from Kinabalu, Borneo and its biogeographical implication. Blumea 46: 447-455.

Zhu H. 2001b. A taxonomic revision of the genus Lasianthus Jack (Rubiaceae) from Thailand. Acta Phytotaxonomica Sinica 39: 116-150.

Zhu H. 2002. A revision of the genus Lasianthus (Rubiaceae) from China Systematics and Geography of Plants 72: 63-110.

\section{IDENTIFICATION LIST}

Numbers after the specimen numbers refer to the species numbers in this revision.

Abbe et al. 10030: 20 - Adelbert 470: 64 - Afriastini 1359: 29; 2369: 56 -Afriastini et al. J-67: 58 - Alleizette 3295: 20 - Alston 12951: 58; 14171: 9 - Ambriansyah \& Arifin AA351: 12; W1022: 53a - Amdjah 19: 76; 366: 37; 614: 78; 1004: 22; 1006: 12; 1020: 12; 1075: 12 - Anang 238: 56 - D. Andau 1049: 70 - Anderson 88: 6b; 202: 115; 8382: 53b - Andong \& Kostermans 23: 35 - Arbain DA239: 125a; DA250: 123a; DA399: 61 - Argent et al. 25383: 102; 25384: 117; 91103: 117 -Arsin 9: 101; 126: 19; 19674: 19 - Atkins et al. 501: 6a - Atmodjo 293: 58 - Avé 24: 123; 99: 58; 100: 123. Backer 3186: 73; 4915: 26; 6058: 56; 6060: 106; 6074: 37; 8957: 117; 9218: 103; 9357: 11; 9929: 11; 9983: 56; 10533: 58; 10699: 103; 10729: 101; 10853: 106; 11063: 102; 13644: 103; 14064: 56; 14163: 73; 14334: 56; 14458: 73; 14599: 19; 14639: 73; 16276: 37; 22515: 23; 22737: 13; 22740: 56; 22988: 101; 23067: 56; 23831: 101; 23934: 56; 25457: 37; 25544: 37; 26272: 89; 31192: 56; 31224: 89; 37545: 73; 37680: 73 - Bakhuizen van den Brink 1555: 64; 1696: 64; 2451: 26; 2472: 26; 2491: 56; 2829: 64; 3673: 26; 3999: 73; 4135: 73; 4337: 11; 4394: 56; 4441: 115; 4456: 11; 4466: 58; 4524: 101; 5539: 101; 7077: 37; 7096: 6a - Balakrishnan 137: 128; 654: 125a; 755: 56; 1664: 128; 3496: 56 - Balansa 640: 20; 2654: 112; 2655: 112; 2656: 6a; 2658: 35 - Barbon et al. PPI8199: 56; PPI8258: 73; PPI9303: 56; PPI12316: 128 - Bartlett 325: 103; 6452: 40; 6552: 47; 6962: 127 - Beaman 7192: 42; 7194: 109; 7244: 103; 7260: 78; 7261: 26; 7276: 59; 7277: 63; 7329: 78; 7368: 103; 7371: 103; 7396: 53a; 7402: 109; 7423: 53a; 7439: 109; 7574: 102; 7643: 102; 7645: 94; 7652: 102; 7656: 37; 7666: 103; 7775: 78; 7783: 70; 7794: 29; 7825: 3; 7837: 102; 8111: 103; 8149: 84; 8170: 63; 8198: 103; 8204: 60c; 8209: 60c; 8225: 103; 8226: 22; 8258: 60c; 8436: 72b; 8444: 11; 8695: 63; 8751: 60c; 8829: 63; 8928: 92; 9088: 42; 9248: 78; 9330: 78; 9337: 103; 9478: 78; 9552: 42; 9828: 12; 9848: 108; 10038: 88; 10163: 37; 10395: 103; 10421: 26; 10579: 63; 10633: 103; 10752: 109; 10788: 103 - Beccari 143: 115; 165: 103; 236: 115; 952: 29; 966: 56; 969: 54 - Berger 531: 19 - Beumée A151: 56; A304: 56; A383: 37; 6713: 29 - Bhargava 3767: 128; 4339: 125a - Bicknell 710: 6a; 860: 26; 942: 56; 964: 85a; 1049: 56 - Blackwood 249: 122 - Bloembergen 3572: 128; 3699: 48; 3906: 122; 3927: 49a; 3939: 103 -Blume s.n. barcode L0000688: 37; barcode L0000691: 64; barcode L0000692: 64; barcode L0000693: 64; barcode L0000694: 64; barcode L0000697: 73; barcode L0000700: 102; barcode L0000701: 102; barcode L0000702: 102; barcode L0000703: 103; barcode L0000707: 115; barcode L0000708: 117; barcode L0000709: 117; barcode L0000711: 127; barcode L0000722: 11; barcode L0057519: 101; barcode L0057520: 128; barcode L0057521: 124; barcode L0057522: 66; barcode L0057523: 66; barcode L0057524: 66; barcode L0057525: 66; barcode L0057526: 66; barcode L0057529: 89; barcode L0305211: 62; barcode L0305213: 62; barcode L0305214: 62; barcode L0305289: 73; barcode L0305583: 115; barcode L0305599: 115; barcode L0310036: 19; barcode L0310418: 54; barcode L0310419: 54; barcode L0310420: 54 - Bogor Botanical Garden 136: 56 - Borssum 1864: 37; 2762: 115; 2804: 122 - Brass 7222: 37; 7223: 25; 12811: 122; 13025: 122; 13639: 26; 13670: 36; 19330: 21; 19883: 21; 25023: 26; 27979: 56; 29258: 21 ; 29476: 69; 31711: 26; 31765: 26 - Bremer et al.1650: 67 - Brinkman 822: $125 a$ - Britton 173: 117; 374: 11 - Brooke 8480: 102; 8484: 102; 8588: 53a; 9115: 111; 9198: 53a; 9337: 102; 9348: 71; 9708: 22; 10420: 63; 10423: 103; 10735: 127 - Bruggeman 236: 106; 662: 73 - BRUN 143: 121; 559: 22; 930: 12; 5767: 102; 15246: 29; 15640: 46; 15797: 17 - BS series 24565: 128; 39562: 125a; 7405: 6a - BSIP 7668: 114; 8509: 114; 10088: 114; 11253: 21; 11660: 114 - Bubung Sk 301: 130 - Bunchuai 55: 73; 591: 19; 600: 23; 608: 63 - Bünnemeijer 380: 37; 438: 37; 1018: 37; 1448: 6b; 1791: 53b; 2075: 56; 2217: 37; 2498: 56; 2647: 101; 2675: 115; 2677: 103; 2883: 115; 3345: 58; 3578: 61; 3686: 61; 3862: 61; 3946: 103; 5483: 103; 5746: 83; 10335: 9; 11010: 124 - Bur. Sci. 38795: 112 - Burkill 244: 4; 976: 125a; 2064: 107; 2305: 72a; 2844: 3 - Burley et al. 858: 11; 1439: 127; 1700: 127; 2353: 117; 2423: 117; 2741: 104; 2894: 76; 3327: 56 - Burut 3000: 78 - Buwalda 221: 6a; 3181: 89; 3320: 124b; 3477: 115; 3478: 64; 3642: 99; 4713: 48; 6269: 72a; 6528: 127; 6546: 79; 7590: 117;
8053: 64 - BW series 4851: 21; 5549: 56; 7950: 56; 8406: 21; 10659 : 113; 10675: 26; 12622: 49a; 13339: 73; 13531: 59; 13870: 26; 14278 : 73 - Bygrave 35: 46

Carr 12000: 21; 12516: 26; 12517: 26; 12539: 21; 12648: 21; 12891: 21; 14365: 26; 14396: 121 - Carrick et al. 21: 53b; 1456: 117 - Chakrabarty 1220: 56; 2076: 56 - Chand 2769: 128; 4746: 49a; 4889: 60a; 5436: 60a; 5438: 60a; 6321: 56 - Chao 883: 49a; 884: 35; 893: 35 - Chew 64: 97a; 232: 82a; 362: 12; 764: 75; 790: 82a; 834: 3; 881: 72a; 1103: 121 - Chew et al. RSNB 974: 11; 1019: 27; 1033: 63; 1435: 63; 1718: 63 - Ching S55287: 53a; S55288: 14 - Chua FRI39084: 44 - Chuang \& Kao 3280 49a; 3439: 49a - Church et al. 10: 128; 198: 53a; 423: 94; 713: 94b; 870: 37; 888: 7; 937: 7; 1441: 68; 1451: 102; 1681: 71; 1789: 128; 1793: 53b; 1930: 53b; 2001: 67; 2051: 53a; 2245: 53a; 2403: 53a; 2424: 72b; 2639 : 65; 2734: 37 - Clemens J. \& Clemens M.S. 343: 21; 1192: 6a; 9467: 12; 26106: 53a; 26221: 63; 26271b: 53a; 26452: 63; 26463: 94; 26657: 78; 27353: 29; 27713: 60c; 27893: 78; 27893b: 60c; 27894: 130; 28105: 130; 28870: 130; 28876: 63; 29561: 130; 29578: 63; 29597: 109; 29691: 108; 29838: 92; 30348: 103; 30400: 53a; 31016: 103; 31479: 103; 32536: 60b; 32538: 42; 32916: 108; 34307: 42; 35158: 42; 40617: 11 - Coert 999: 26; 1423: 48 - Colfs 194: 48 - Collenette 21578: 42 - Collins 819: 128 - Conn 1719: $6 a$ - Coode 5493: 117; 5846: 125a; 6402: 123; 6896: 72b - Craven \& Schodde 1082: 49a; 1403: 131 - Curtis 284: 35; 2081: 87.

Dakkus 264: 100 - Danser 5725: 106; 5743: 115; 5761: 101; 5773: 106; 5788: 64 - Dausus G.48: 128 - Davidse 7907: 103 - Davis 481: 17; 706: 56; 707: 59 - De Jong 760: 71; 889: 67 - De Silva s.n. ex Wall. Cat. 8442: 6a-De Vogel 886: 29; 1319: 94; 1739: 102; 1772: 117; 2766: 54; 2832 : 101; 5124: 26; 5136: 92; 5344: 92; 8262: 103; 8266: 53a; 8392: 63; 8674: 60b - De Vogel \& Vermeulen 6518: 21; 6608: 21; 7567: 115; 7612: 58; 7617: 100 - De Voogd 118: 101; 220: 6a; 3147: 49a - De Wilde \& De Wilde-Duyfjes 12014: 117; 12014A: 56; 12343: 11; 12346: 94; 12626: 6a; 13034: 115; 13225: 121; 13771: 115; 14518: 37; 14604: 102; 14627: 37; 14635: 56; 14723: 115; 14760: 103; 14766: 126; 15219: 110; 15487: 117; 15503: 6a; 15742: 56; 15794: 115; 15864: 56; 16596: 102; 16785: 121; 16786: 110; 18104: 56; 18625: 126; 18720: 102; 18748: 56; 18784: 127; 18816: 29; 18849: 117; 19004: 58; 19729: 102; 19952: 102; 20044: 37; 20231: 40; 20236: 6a; 20299: 117; 20332: 40; 20412: 40; 21238: 29 Dennis RSS2145: 114 - Dilmy 434: 115 - Din \& Shi 232: 49a - Djamhari 68: 101 - Docters van Leeuwen 3251: 127; 3927: 101; 3928: 115; 9200: 25; 10474: 26; 10710: 25; 10727: 25; 10996: 49a - Dorgelo 125: 22 - Dransfield 968: 115; 2487: 64; 6343: 88; 6537: 77; 6854: 72b; 7069: 12 - Dyg Awa et al. 44116: 67 .

E.G.1532: 123 - E. Hainan Expedit. 530: 89 - Eberhardt 1981: 35; 2050 : 49a; 3852: 59 - Edaño PNH21: 11; PNH6617: 11; PNH14225: 20 - Elbert 253: 60a; 254: 73; 4429: 128 - Elmer 5778: 6a; 6977: 6a; 7050: 128; 7597 : 85a; 7634: 85a; 7748: 85a; 7787: 73; 8839: 49a; 9536: 73; 9586: 11; 9687 : 106; 11297: 117; 11341: 49a; 12148a: 56; 13252: 90; 13613: 26; 13790 : 49b; 14007: 128; 14041: 6a; 14153: 56; 14261: 120; 15705: 37; 16522: 128; 16532: 26; 20147: 103; 20520: 117; 20913: 103; 21046: 53a; 21169: 102; 21212: 12; 21358: 29; 21423: 6a; 21634: 53a; 21656: 12; 21865: 30; 21967: 128; 22045: 49a; 22079: 6a - Endert 2661: 76; 2769: 37; 2828: 121; 2973: 117; 3627: 53a; 4096: 37; 4358: 103; 4572: 103; 4814: 54 - Eyma 15: 13 ; $1954: 13 ; 4827: 124$.

Fallen 239: 23 - Fenix 12619: 26 - Forbes 203: 26; 266: 56; 296: 58; 313: 113; 570: 58; 741: 19; 786: 64; 1007: 26; 1074: 64; 1085: 60a; 1817: 101; 2194: 58; 2418a: 75; 2573: 101; 3096a: 37; 3175a: 102; 3707: 128 - Ford 66: 49a; 113: 125a - Fosberg 36993: 128; 37158: 128; 37201: 6a; 37241: 56; 37364: 56; 44588: 125; 44589: 73 - Franken \& Roos 306: 127 - Frodin \& Pullen UPNG867: 26 - Fuchs 21320: 72b - Fuentes et al. PPI37061: 21; PPI37225: 21; PPI38961: 128; PPI38966: 56 - Fukuoka T-36217: 23; T-62359: 60a; T-62361: 6a ; T-62491: 6a; T-63785: 60a; T-63786: 35; T-63815: 20 - Fukuoka et al. T-177: 6a; T-34554: 60a; T-34620: 60a; T-35953: 117; T-35954: 23; T-35955: 102. 
Gaerlan et al. 3458: 6a; PPI2655: 49a; PPI19900: 128; PPI23712: 16 Galoengi 334: 54 - Garcia et al. PPI15287: 56; PPI15290: 21; PPI15979: 85a; PPI18144: 56 - Gardette E.G. 1532: 123; 1914: 6a - Garrett 384: 60a; 879: 60a - Geesink 9034: 103; 9144: 63; 9159: 103; 9271: 60c ; 9326: 117 - Geesink et al. 5035: 23; 5695: 128; 6259: 29; 6493: 56; 6494: 23; 6574: 56; 6601: 29; 6653: 56; 6877: 128; 7374: 23; 7573: 117; 7578: 102; 7755: 56; 7782: 35 - Gjellerup 485: 26; 1228: 73 - Grashoff 680: 127 Gressitt 292: 49a - Griffith 2929: 73.

Halle 1997: 102 - Hallier 26: 81; 67: 115; 120: 64; 164: 106; 200: 101; 232: 117; 245: 64; 333a: 115; 385: 115; 421: 73; 461: 117; 1737: 103; 1738: 115; 1762: 6a; 1919: 81; 1967: 81; 2004: 29; 2016: 71; 2416: 37; 2882: 53a; 2884: 29; 2904: 37; 2981: 22; 3083: 76; 3289: 76 - Hance 18438: 6a - Hansen 295: 72b; 607: 6a; 1622: 111 - Hansen et al. 11088: 6a - Hardial 600: 23 - Harmand 916: 35; s.n. (Pierre Herb. no. 6173): 125a - Hartley TGH10693: 26; TGH10742: 21; TGH10791: 21; TGH11377: 56; TGH12643: 23 - Hasskarl 18121: 6a - Hatusima 18788: 49a; 19169: 49a; 19171: 6a; 20190: 35 - Hatusima \& Sako 21542: 49a; 23872: 6a - Haviland 1119: 42; 1141:108; 1241: 78; 1300: 78; 1306: 63; 1323: 63 - Haviland \& Hose 3441: 12 - Henderson 18008: 75; 19732: 79 - Hennipman 5214: 26; 6118 : 21 - Hochreutiner 222: 62; 241: 101; 249: 101; 250: 64; 781: 29; 1172: 60a - Holstvoogd 353a: 124 - Hoogerwerf 53: 89; 218a: 125b; 237: 89; 250: 124; 252: 59 - Hooker \& Thomson 11: 112 - Hoop 51: 37 - Hopkins \& Naoni 455: 23 - Hose 117: 12; 156: 123; 634: 68 - Hosseus 353: 73 - Hotta et al. 10: 115; 19: 115 ; 79: 58; 178: 42; 201: 57 - Hou 278: 109; 626: 56; 659: 56 - Hu \& But 20974: 20; 21958: 20 - Huang T.C. 6475: 49a - Huang T.C. \& Kao M.T. 5134: 56; 6282: 128.

Iboet 35: 54; 42: 128 - Idjan 287: 26 - Ijiri \& Niimura 694: 21 - Irawati 209: 6a-Ismael 3: 18; 5: 100 - Iwatsuki et al. 17: 49a; P854: 73; 910: 11; P1185: 6a; P1279: 73; P1292: 26; P1373: 73; P1375: 73; S926: 56; S958: 121; T8307: 49a; T8308: 6 a.

Jaag 363: 21 - Jacobs 4480: 26; 4666: 83; 4824: 128; 7576: 49a; 7796: 85a; 8139: 11; 8158: 59; 8442: 104; 8705: 69 - Jaheri 265: 37; 318: 117; 391 : 117; 880: 37 - Jarvie et al. 5218: 53a; 5700: 29; 6063: 102 - Jayasuriya \& Premadasa 1647: 128 - Jeng 512: $6 \mathrm{a}$ - Johansson et al. 60: 117; 118 : 125a; 209: 125a - Johns et al. 129: 124 - Junghuhn 287: 19; 321: 101; 342: 115 .

Kadir \& Enggoh 10339: 72b - Kajewski 2612: 114 - Kalkman 4154: 49a; 4234: 49a - Kamarudin FRI34510: 52 - Kao M.T. 5555: 128; 5939: 49a; 5970: 35; 6678: 49a - Kartawinata 705: 76; 767: 94; 774: 29; 1013: 117; 1029: 102; 1037: 104; 1149: 64 - Kasik 5: 19 - Kasim et al. 01708: 103 - Kato \& Miki 273: 35 - Keng H. 1043: 128 - KEP-FRI series 343: 94; 1931: 103; 1957: 29; 1958: 123; 4437: 104; 4881: 131; 5476: 79; 6111: 56; 6443: 79; 7159: 94; 8536: 97a; 10854: 72a; 10973: 14; 11081: 53a; 12325: 6b; 12392: 74; 12655: 20; 12904: 103; 13202: 6b; 13429: 102; 14793: 97a; 15573: 93; 15583: 3; 15716: 34; 16651: 53a; 16861: 53a; 18077: 118; 20188: 53a; 20679: 131; 22027: 41; 23067: 98; 23311: 104; 25173: 97a; 25703: 123; 28310: 53a; 30929: 53b; 32032: 107; 32036: 115; 32705: 103; 35229: 75; 46934: 118; 94488: 87; 98994: 53b; 99775: 94; 104440: 97a; 104635: 72a; 104817: 8 - Kern 7458: 19; 8577: 11; 8618: 56 - Kerr 9845: 6a; 10833: 59; 11941: 97b; 14117: 118; 14940: 29; 15435: 29; 15930: 118; 16700: 97b; 18809: 40; 19424: 11; 21327: 4; 21510: 128; 21591: 128; 21708: 11 - Kessler PK32: 43; PK150: 22 - Kew Dist. 869 (Griffith s.n.): 97a; 871 (Maingay 1699): 102; 2918 (Griffith s.n.): 97a; 2922 (Griffith s.n.): 131; 2929 (Griffith s.n.): 127; 2934 (Griffith s.n.): 40; 2935 (Griffith s.n.): 53a - Kiah 24312: 50 - Kiapranis LAE 69008: 91 - King 857: 45 - King's collector 237: 6a; 402: 87; 472: 37; 3209: 103; 4128: 87; 4462: 87; 10100: 127 - D.W. Kirkup \& S. Thomas 619: $111-\mathrm{KL}$ series 437: 6a; 489: 87; 1500: 87; 1755: 29; 3492: 103; 3633: 53b - Klackenberg \& Lundin 800: 103 - Kleinhoonte 30: 101; 31: 115; 65: 13; 172: 19 - Koelz 27222: 73; 28218: 73; 30127: 60a - Kokawa \& Hotta 389: 78; 401: 37; 840: 117; 2218: 103; 2394: 53a; 2843: 109; 4236: 60b; 4991: 37; 4995: 53a; 5382: 53a; 5624: 109; 5916: 53a; 6057: 63 - Koorders 6547: 101; 6549: 64; 21800: 115; 22224: 115; 23209: 60a; 24328: 56; 24335: 64; 24340: 101; 24475 : 37; 25782: 115; 26369: 26; 26418: 101; 26456: 64; 26614: 49a; 26710: 60a; 27423: 6a; 31949: 124; 32065: 106; 32858: 64; 32909: 56; 33234: 56; 34814: 60a; 36715: 73; 39097: 115; 39250: 6a; 39513: 56; 40638: 64; 42109: 73; 43989: 29; 44074: 29; 44093: 56; 47940: 6a-Kostermans 4546: 29; 4550: 12; 5720: 12; 6255: 128; 6299: 89; 6305: 56; 6393: 12 ; 6661: 6a; 7906: 56; 9323: 12; 9872: 29; 10039: 53a; 10493: 76; 10627: 12; 13092: 53a; 13819: 117; 18718: 6a; 21875: 102; 22002: 29; 22011: 102; 22046: 29; 23508: 103; 23916: 64 - Kostermans \& Anta 92: 35; 132: 29; 186: 104; 683: 56; 707: 53b; 1297: 53b; 1366: 6b; 1387: 6b - Kostermans et al. 395: 21; 396: 21; 416: 122a; 490: 6a; 521: 21; 653: 26 - Koyama et al. 10591: 123; T31581: 56; T61218: 49a-Krukoff 4061: 103; 4068: 56 - Kuntze 4565: 101 - Kuo C.C. 1172: 6a; 1182: 35 - Kwangtung 786138: 6a; 79-6119: 20; 80-6279: 49a; 82-5696: 125a.

LAE series 50043: 21; 51237: 21; 51745: 113; 56802: 21; 57478: 23; 58086: 122; 58297: 49a; 58299: 122; 58400: 26; 58663: 21; 63325: 85a; 64227:
21; 67926: 26; 73543: 21; 73750: 113; 74795: 21; 74813: 21; 77186: 26 ; 77522: 26 - Lam 19: 103; 154: 115; 176: 19; 309: 26; 310: 73; 793: 21; 797: 25; 936: 25; 975: 25; 1217: 21; 2252: 56; 7708: 21 - Laman et al. TL44: 53a; TL62: 102; TL228: 127; TL232: 37; TL285: 37; TL801: 5; TL990: 117 - Lamont 325A: 6a-Lanjouw 50: 23; 202: 64 - Larsen et al. 198: 23; 808: 6a; 9157: 125a; 32752: 29; 32851: 29; 33176: 40; 33318: 102; 33320: 23; 33461: 97b; 33863: 128; 45393: 125b; 45620: 40; 45955: 27; 46093: 4; 46316: 112; 46436: 89 - Latiff et al. 3948: 33 - Lau S.K. 20212 20 - Laumonier TFB59: 101; TFB809: 127; TFB1047: 56; TFB3838: 94; TFB3869: 25 - Ledermann 6630: 21; 9373b: 69; 9764: 25 - Lei 1025: 125b - Leonardo 3271: 49a - Lesger 379: 56 - Lörzing 1828: 101; 4719: 58; 4929: 26; 4933: 103; 5243: 56; 5285: 117; 5473: 56; 5606: 81; 5790: 54; 5801: 37; 5886: 54; 5977: 130; 6916: 54; 6972: 56; 8622: 115; 11395: 54; 13729: 103; 14599: 29; 14609: 117; 14929: 130; 15111: 106; 15201 : 40; 15915: 56; 16099: 29; 16227: 47; 16434: 56; 16691: 56 - Lütjeharms 3759: 125a; 4109: 128; 4700: 117.

Mabberley 1563: 128 - Madulid 6821: 6a - Madulid et al. PPI3085: 85a; PPI3089: 49a; PPI20187: 21; PPI21048: 128 - Maingay 866: 127; 867: 72a; 868: 6b; 869: 53a; 870: 56 - Manner \& Street 519: 49a - Maradjo 378: 54 - Martin S39288: 115 - Maskuri 26: 56; 884: 102 - Mathew S.P. 21144: 6a - Matthew K.M. 26773: 128; 28243: 128 - Maxwell 74-883: 56; 74-924: 11; 75-192: 128; 75-484: 128; 75-793: 59; 76-145: 6a; 76-211: 23 ; 78-70: 29; 81-48: 104; 82-72: 6b; 82-100: 29; 82-124: 53a; 82-276: 100 82-279: 53a; 85-1112: 29; 85-1113: 117; 86-30: 20; 87-251: 56; 87-525: 56; 87-710: 23; 87-1040: 23; 87-1194: 6a; 88-578: 89; 90-418: 73; 90-564: 23; 90-1279: 89; 92-195: 49a; 92-332: 23; 93-523: 23; 93-1207: 6a; 94-1235: 125a; 96-1424: 6a; 96-1655: 73 - McDonald \& Afriastini 3440: 37; 3441: 102; 3377: 56 - McGregor 32292: 85a-McKee 1861: 23 - Meijer 45: 64; 431: 103; 1006: 12; 1353: 101; 1433: 101; 2433: 37; 2706: 64; 5004: 101; 6151: 9; 6767: 102; 7613: 26 - Merrill 5739: 49a; 7041: 73 - Meyer Drees 41: 111 - Milliken 954: 115; 964: 122 - Mitsuta T45322: 60a; T48760: 73 - Mogea 2347: 73 - Mogea et al. 3590: 22; 3748: 102; 4019: 7; 4020: 53a; 4094: 53a; 4166: 29; 4193: 53a; S52750: 102 - Mohtar et al. S49487: 72b ; S65895: 53a - Moi W. et al. 105: 26 - Monchy de 107: 101 - Mondi 130: 56; 292: 22 - Moulton 2019: 53b - Mousset 148: 113 - Muchtar 46A: 127 - Murata et al. B377: 37; B379: 37; B1220: 53a; B1224: 53a; B1233: 53a; B1724: 22; B1745: 53a; B2301: 12; B2306: 111; B2363: 53a; B2836: 22; B3922: 11; J933: 100; J1914: 115; T15785: 73; T16246: 56; T16248: 23; T16252: 89; T16350: 89; T17438: 29; T17441: 56; T17449: 89; T17596: 23; T37192: 128; T41659: 20; T41672: 23; T42684: 35; T42686: 73; T42850: 60a; T42855: 35; T42856: 35; T42858: 23; T42896: 60a; T51489: 20.

Nagamasu 3046: 115; 3098: 101; 3114: 15; 3121: 75; 3140: 57; 3271: 102; 3277: 123; 3359: 15; 3371: 58; 3373: 115; 3390: 75; 3526: 101; 3656: 42; 3678: 115; 3691: 43; 3821: 15; 3836: 75; 3873: 75; 3874: 115; 3979: 42; T49936: 49a - Nair 840: 125a - Nakaike 633: 6a-Nedi 9: 13; 582: 117 - NGF series 8384: 122; 11909: 36; 14310: 21; 14942: 122; 17907 : 6a; 19142: 21; 19155: 6a; 19477: 21; 20351: 49a; 20757: 122; 21601: 124; 23419: 124; 25710: 36; 26121: 23; 26665: 21; 28869: 36; 28889: 26; 29101 : 122; 31009: 26; 32267: 21; 33453: 117; 33458: 56; 33463: 25; 33469: 117; 33790: 49a; 38035: 117; 39913: 26; 39936: 85b; 41478: 21; 45378: 122; 47659: 49a; 48185: 21 - I. Nielsen \& H. Balslev 1086: 111 - Nitrasirirak 215: 102 - Nitta 15124: 115; 15186: 60a - Noguchi 3186: 6a; 3187: 35; 3188: 49a; 3516: 49a - Noor MN48: 125a; SRMN28: 6b - Nooteboom 962: 29; 1077: 37; 1167: 77; 1367: 115; 1450: 53a; 4189: 7; 4203: 76; 4225: 22; 4340: 76; 4560: 117; 4657: 102; 4735: 7; 4743: 102; 5189: 113.

Odashima 11131: 20 - Ogata 10618: 103; 10815: 53a; 10865: 102; 11285: 60c; 11297: 103; 11310: 60c; 11567: 37.

Panigrahi 3613: 60a; 4136: 73; 4845: 60a - Partomihardjo 1581: 73 - Paul Chai 34805: 51 - Pereira et al. 84: 60c; 90: 60c; 125: 53a; 163: 103; 169: 103; 173: 103; 711: 103 - Phengkhlai 136: 102; 137: 35; 150: 102; 212: 128 ; 503: 6a; 3234: 20 - Pickles 2934: 115; 3673: 99 - Pierre 587: 128; 1316 : 23; 3256: 56; 3257: 20; 3258: 20; 3266: 49a; 3267: 23 - Pipoly et al. 170: 12; PPI38153: 56; PPI38172: 56 - Pleyte 16: 115; 62: 101; 68: 101; 175: 48 - Ploem 18966: 19 - PNH series 995: 73; 1370: 73; 1477: 73; 1910: 117; 2134: 73; 2851: 73; 3260: 73; 3476: 117; 3506: 117; 6095: 6a; 6379: 56; 6606: 56; 6615: 26; 6635: 106; 6677: 26; 6678: 6a; 7127: 85a; 7178: 85a; 7184: 6a; 7197: 85a; 7312: 21; 7378: 85a; 9978: 73; 13747: 117; 14208: 56; 14225: 20; 14487: 6a; 17697: 21; 19771: 6a; 21490: 56; 21496: 6a; 21867 : 21; 21875: 128; 21913: 21; 21920: 49a; 21924: 49a; 21984: 73; 22016 : 49a; 36122: 6a; 37840: 128; 38481: 21; 38795: 112; 41894: 6a; 72623: 49a; 72624: 85a; 77992: 128; 78175: 6a; 78255: 56; 117173: 128; 117189: 56; 117396: 6a; 117792: 6a; 118056: 128; 118439: 6a - Poilane 234: 60a; 283: 20; 2327: 20; 40832: 23 - Popta 1507: 64 - Posthumus 776: 53a - Prance et al. 30620: 17 - Prawiroatmodjo \& Maskuri 1423: 102 - Provencher T56: 6a - Puasa-Angian 3967: 119 - Puff et al. 900808-1/4: 111; 900809-1/1: 117; 900809-1/3: 12; 900812-1/1: 72b; 900818-1/1: 37; 900818-1/8: 117; 900819-1/2: 78; 900829-1/2: 12; 920420-1/3: 37 - Pullen 943: 21; 7424: 21; 8271: 26 - Purseglove P4172: 103; P4518: 40; P4553: 29; P4669: 94; 
P4687: 37; P4784: 53a; P4869: 22; P4915: 22; P4931: 53b; P5121: 102; P5218: 102; P5271: 53a; P5335: 117; P5467: 117 - Put 1195: 32.

Raap 148: 6a; 166: 64; 200: 101; 241: 115; 252: 26; 538: 29; 564: 81; 743: 115; 778: 115 - Rachman et al. 3: 6b; 4: 56 - Rahayu \& Maskuri 381: 125a - Rahmat si Boeea 3484: 29; 5437: 29; 5705: 127; 5757: 127; 6253: 102; 8604: 127; 9232: 81; 9406: 37; 9499: 53a; 9992: 37; 10183: 130; 10185: 103; 10190: 103; 10397: 75; 10582: 75; 10729: 103; 10877: 42; 11032: 130; 11083: 103 - Ramlan 091: 115 - Ramos BSN 13982: 56; 14508: 11; 14619: 85a; 15274: 6a; 41250: 56 - Ramos \& Edaňo 30682: 85a; 30865: 56; 38058: 1; 38763: 56 - Ramsri 70: 50 - Rao 9082: 6a - Rao et al. K8015: 103 - Rau K. 389: 2 - Reksodihardjo 137: 64; 140: 102 - Rena et al. S58966: 67 - Reynoso \& Majaducon 24890: 11 - Reynoso et al. PPI1157: 21; PPI7333: 128; PPI11170: 128; PPI11373: 128; PPI14273: 21; PPI14448: 85a; PPI14515: 85a - Richards 1010: 12; 1061: 37; 1114: 51; 1284: 102; 1351: 102; 1467: 51 - Ridley 140: 22; 2904: 11; 3219: 74; 6463: 53b; 8213: 37; 8578: 45; 9095: 104; 9703: 12; 9715: 37; 10948: 6a; 11486 (14490 in publication): 52; 12542: 40; 13628: 28; 13630: 82a; 13631: 107; 14007: 93; 14008: 3 ; 14009: 58; 14487: 33; 14488: 40; 15689: 95; 15690: 98; 16121: 47 - Ridsdale 800: 117; 836: 117; 944: 6a; 983: 6a; 1046: 105; 1152: 117; 1706: 85a; 1711: 85a; 1753: 73; 1757: 85a; 1933: 37; 2456: 37; 2632: 69; PBU365: 117; PBU451: 117; SMHI1701: 128; SMHI1837: 105 - Ridsdale et al. 5476: 11; ISU321: 128 - Robinson 6202: 85a; 6559: 73; 9830: 73 - Romero \& Fuentes PPI37505: 128 - RSNB series 215: 111; 250: 37; 798: 108; 839: 108; 1256: 78; 1355: 78; 4033: 109; 4118: 109; 4155: 109; 4598: 109 .

S series 2936: 117; 3504: 111; 3708: 68; 3873: 116; 4512: 60c; 4513: 63; 8475: 29; 8770: 82b; 12487: 53b; 13619: 39; 14791: 102; 14792: 103; 14793: 115; 16556: 51; 16665: 53b; 16754: 22; 17842: 53b; 18208: 72b; 18876: 39; 19397: 82b; 19719: 53b; 19948: 117; 21641: 12; 21664: 117; 22787: 72b; 22804: 68; 22990: 53a; 23336: 72b; 27239: 51; 28493: 29; 29123: 51; 31102: 29; 31536: 123; 32615: 53a; 32693: 117; 32760: 53a; 32889: 51?; 32936: 55; 33047: 53b; 33331: 76; 33582: 53a; 33809: 10; 33826: 96; 33878: 96; 33966: 103; 34053: 7; 34258: 102; 34913: 53a; 34991: 111; 35169: 39; 35380: 109; 35424: 115; 35572: 103; 36087: 37 ; 36163: 103; 36226: 53a; 36352: 53a; 36803: 39; 37329: 22; 37447: 127; 39234: 53b; 39325: 53a; 39335: 111; 39588: 72b; 39676: 111; 39988: 99; 40652: 76; 40794: 67; 40861: 53a; 41248: 76; 41928: 59; 41976: 37; 42220: 53b; 42455: 39; 42508: 37; 42843: 111; 43027: 72b; 43146: 72b; 43203: 67; 43843: 29; 44116: 67; 44404: 115; 44480: 60b; 44924: 53a; 45006: 37; 45189: 6a; 45380: 29; 45841: 29; 45874: 53a; 46999: 39; 47207: 51; 47339: 116; 47504: 29; 47533: 6a; 47601: 53a; 47839: 38; 48901: 37; 48941: 116; 49001: 51; 49087: 72b; 49216: 53a; 49382: 53a; 49383: 117; 49399: 53a; 50496: 53b; 50501: 115; 50579: 38; 51624: 103; 51640: 53a; 52056: 53a; 52374: 37; 52556: 31; 52977: 53b; 53651: 53a; 54003: 53a; 54731: 111; 54735: 76; 54758: 12; 56055: 76; 57151: 97a; 57626: 53a; 58317: 102; 58341: 12; 60344: 60c; 61432: 53a; 64427: 12; 66143: 6a - Saito 7046: 35; 7128: 128; 7291: 6a - SAN series 26872: 78; 28270: 78; 33276: 117; 33896: 109; 34923: 72c; 38323: 108; 67607: 12; 69225: 37; 70884: 29; 71057: 102; 74463: 78; 77536: 12; 79334: 12; 79684: 37; 81047: 68; 83017: 37; 83023: 102; 85255: 123; 86828: 56; 90642: 72b; 91035: 94; 93988: 56; 95154: 78; 96680: 109; 97583: 94; 99764: 12; 106675: 109; 107176 : 37; 108936: 53a; 111314: 103; 111525: 117; 112143: 94; 115914: 12; 116811: 12; 117593: 12; 118176: 103; 118358: 12; 118556: 46; 118646: 46; 121946: 29; 123429: 53a; 129487: 59c; 132988: 12; 136086: 53a; 136779: 46; 136799: 46; 136864: 111; 141728: 6a - Sands 5244: 60c; 5747: 117; 5848: 117; 5971: 12; 6392: 56; 6482: 56; 6598: 23; 6620: 23 -Sands et al. 1321: 85a; 1469: 21; 1951: 59 - Santos 31887: 49a - Sarip 279: 49a - Sathaphon et al. 104: 117; 247: 37 - Saw FRI36403: 103 - Scheffer 4597: 106; 18929: 56; 18985: 73 - Schiffner 2652: 101; 2660: 73; 2673: 37; 2678: 37; 2679: 56 - Schlechter 17805: 36; 18625: 128; 19334: 37 - Schmidt 683: 102 - Schmutz 56: 6a; 376: 73; 479: 19; 4835: 128; 4867: 48; 5814: 11; 5858: 49a - Schodde 2273: 124; 2897: 21; 2980: 21 ; 3130 : 56 - Scortechini 29: 45; 190: 45; 329: 32; 332: 95; 342: 83; 411: 110; 1207 : 37; 6172: 53a - Serian, B. \& K. Bremer 1650: 67 - SF series 18962: 78; 32244: 127; 39904: 97a; 40118: 87 - Shah 196: 37; MS1418: 6b; MS1435: 131; MS1540: 97a; P5645: 53b - Shah \& Ahmad MS2277: 53a; MS2300: 104 - Shah \& Kadim MS507: 97a - Shah \& Noor MS658: 103; MS710: 45; MS711: 72a; MS1787: 97a; MS2024: 40 - Shah \& Sidek MS1132: 37 - Shea 23884: 117; 26887: 103; 27982: 53a; 28148: 116; 28211: 116; 28267: 81; 28285: 115 - Shimizu et al. M13351: 93; M13352: 103; M13638: 103; M13834: 6b; M13836: 72a; M13836b: 127; M13873: 58; M13962: 104; M13964: 127; T7754: 125b; T8063: 125a; T8858: 20; T14714: 125b;
T18113: 60a; T19560: 20; T19583: 89; T19601: 49a; T19603: 6a; T23460: 23: T23729: 56; T23734: 49a; T23782: 49a; T23830: 56; T26200: 97a; T226633: 23 - Simpson 2076: 72b; 2118: 12; 2201: 46; 2451: 102; 2518 : 37 - Sinclair et al. 9038: 108; 10439: 53b - Sirirugsa 1034: 4 - Smith J.J. 874: 13 - Smith J.J. \& Rant 360: 115; 370: 73; 616: 103; 676: 117 - Smitinand 460: 128; 944: 6a; 1408: 56; 1413: 89; 5689: 56 - Soedarsono 249: 102; 250: 79; $327: 79$ - Soegandiredja $83: 26$ - Soejarto et al. $6053: 128$; 7656: 128; 7807: 128; 8295: 125a; 8312: 128; 8747: 128; 8845: 6a - Soembawa 194: 48 - Soepadmo 160: 29; 908: 118; 1043: 131 - Sørensen et al. 649: 56; 666: 56; 3060: 23; 3061: 23; 6335: 49a; 6339: 49a - Stevens et al. 56: $6 \mathrm{a} ; 364: 37$; 370: 12; 416: 102; 489: 70; 524: 117 - Stone 5736: 87; 5985: 98; 7190: 131; 10945: 11; 11053: 98; 11424: 109; 14079: 83; PPI6270: 49a - Stone et al. 522: 85a; 659: 85a; 6178: 128; 8569: 118; 12409: 96; 12518: 104 - Streimann 8460: 85b; 8507: 122 - Stresemann 91: 6a - Sugau et al. JBS178: 12; JBS250: 37; JBS305: 104 - Sundaling SAN135221: 94 - Surbeck 44: 53b - Suvarnakoses 1867: 102.

Ta-Yi Liu 6: 49a - Tagawa et al. T472: 49a; T473: 60a; T1214: 60a; T1597: 73; T2859: 73; T5323: 29 - Takeuchi 4754: 25; 5096: 69 - Takeuchi et al. 11397: 113 - Tanaka \& Shimada 11124: 128 - Teysmann 1567: 56; 4273 128; 4540: 56; 8005: 11; 8360: 6a; 10833: 29; 12681: 89; 13787: 6a; 18354: 56; 19330: 56; 19344: 56; 19401: 22; 19414: 56; 19423: 6b; 140216: 22 - Ting \& Chen 69: 49a; 74: 6a; 423: 20; 517: 20 - Toxopeus 206: 56; 421: 73 - Tsang W.T. 23940: 112; 29013: 56; 29874: 35; 30333: 20; 30459: 35; 30745: 20 - Tsiang 55: 35 - Tsugaru T61639: 89; T61770: 60a; T61776: 60a - Tukirin 402: 22.

Ueda et al. C4350: 49a - Unesco 61: 56; 118: 102; 119: 102 - University of San Carlos 59A: 6a; 553A: 73; 694: 26 - Unknown collector 10410: 11 - UPNG 1325: 113

Valeton 236: 106 - Van Balgooy 3009: 115; 3306: 11; 5800: 37 - Van Balgooy et al. 2839: 101; 2854: 101; 2892: 115; 4289: 101; 5367: 53a; 5396: 5; 5459: 102; 5490: 102 - Van Beusekom et al. 633: 95a; 696: 29; 700: 102; 782: 27; 798: 6a; 1697: 60a; 1822: 89; 1870: 89; 1881: 128; 1885: 118 2199: 23; 2201: 49a; 2202: 60a; 2675: 6b; 3210: 56; 3210A: 56; 3211: 23 3231: 50; 3270: 23; 3272: 23; 4116: 128; 4358: 56; 4360: 23; 4452: 89 ; 4456: 128; 4558: 60a; 4561: 35; 4563: 23; 4564: 49a; 4564A: 49a - Van der Meer-Mohr 34: 56 - Van Kregten VK28: 56 - Van Leeuwen 3203: 117 3942: 54; 8262: 58 - Van Ooststroom 12924: 115; 13230: 61; 13233: 13 13956: 101; 13961: 19; 14069: 101 - Van Royen 3183: 56; 3342: 25; 3564: 25; 5153: 56; 5163: 56; 11176: 26 - Van Royen \& Sleumer 6356: 25; 6395 25; 6747: 23; 6870: 23; 7272: 103; 7592: 37; 7686: 37 - Van Slooten 2115: 81; 2251: 102; 2252: 117 - Van Steenis 1114: 29; 1116: 37; 1343: 56; 1361 37; 2314: 11; 2743: 56; 3738: 75; 3788: 56; 8328: 60a; 9247: 56; 9519: 103; 9523: 103; 9545: 121; 9721: 115; 9886: 126; 9922: 115; 9969: 101; 10819: 115; 12440: 73; 12673: 56; 12772: 60a; 12936: 73; 17542: 101; 20591: 128; 20783: 35 - Veldkamp 7025: 73; 8003: 7; 8004: 53a; 8015: 53a; 8048: 123; 8075: 37; 8144: 76; 8272: 6a; 8474: 22 - Verheijen 704: 6a; 705: 6a; 2359: 48; 2363: 125a; 2365: 128; 2678: 19; 2679: 73; 2933 19; 2942: 73; 2953: 19; 3015: 73; 3031: 19; 3158: 6a; 3173: 128; 4035: 11; 4073: 73; 4079: 6a; 4760: 11; 4768: 6a; 4769: 19; 4772: 49a; 4781: 49a - Verhoef 90: 102 - Vermeulen 788: 22 - Versteeg 1228: 117; 1406 56; 1434: 25 - Vidal 390: 85a; 1058A: 128 - Vinas \& Lelean LAE59326: 26 - Vreeken-Buijs 11: 72a; 33: 72a.

Walker \& Tawada 6739: 6a - Walker et al. 5882: 128; 6064: 128; 6642: 128; 6738: 49a; 6975: 49a; 7012: 35 - Wall. Cat. 8306: 106; 8310: 23 ; 8441 p.p.: $32 ; 8441$ p.p.: 34 - Wang 80524: 23 - Wang C.M. et al. 2249: 49a - Webb et al. CW3500: 56 - Whitford 247: 85a - Whitmore FRI15341: 72a; RSS6051: 114 - Whitmore \& Kalima TCW3247: 94; TCW3284: 37 - Whitmore \& Sidiyasa TCW3418: 21 - Widjaja EAW4310: 73 - Wilkie 93375: 102 - Winckel 5: 64; 41: 64; 133: 58; 210ß: 13; 1707ß: 115; 1817ß: 101; 1916ß: 100 - Winkler 430: 68; 508: 116; 1364: 86 - Wirawan 70: 102; 132: 40; 174: 102; 228: 115 - Wiriadinata 126: 19; 250: 102; 374: 49a; 3249: 53a; 3324: 29; HW119: 101 - Wiriadinata \& Maskuri 617: 102; 637: 37 - Wisse 1024: 19 - Woerjantoro 127: 56 - Womersley \& Lam 6233: 21 - Wong 225: 37; 404: 31; 775: 53a; 1569: 72c; 1688: 103; 2275: 70; 2323: 12 - Worthington 13324: 72a - Wray 257: 128; 270: 95; 413: 3; 2019: 117; 2588: 37; 2590: 87; 3451: 37; 3911: 44; 4109: 35; 4128: 94a - Wright 242: 20.

Yamazaki 6473: 6a - Yip H.G. 159: 20 - Yoshida 1545: 64; 1605: 115 - Yunnan-expedit. 59-13346: 89 - Yusuf \& Wahyono 68: 103; 69: 58.

Zahro 108: 56; 114: 115; 115: 11 - Zainudin AZ5469: 6a - Zhu 98-7-01: 60b; 98-7-02: 60c - Zollinger 593: 56; 594: 23; 621: 23; 1277: 64; 1478: 102. 


\section{INDEX}

Accepted names are in roman type. New names are in bold type; synonyms and superfluous names are in italics. The number after each name is the number of the species as used in this revision; (dub.') refers to dubious taxa, (dub.\& syn.) to synonyms of dubious taxa, and (excl.) to excluded from Lasianthus.

Canthium furcatum Miq. (dub. \& syn.)

Dasus verticillatus Lour. 128

Lasianthus acuminatissimus Merr. 1

acutatus Miq. 2

andamanicus Hook.f. 128

var. ciliatus Deb \& M.Gangop. 125a

angustifolius King \& Gamble 3

apiocarpus (Korth.) Miq. (dub.)

appressus Hook.f. 4

atroneurus $\mathrm{H}$.Zhu 5

attenuatus Jack 6

var. attenuatus $6 a$

var. minor H.Zhu $6 \mathrm{~b}$

var. subsessilis Valeton $6 a$

baasianus $\mathrm{H}$.Zhu 7

barbatus H.Zhu 8

barbellatus Ridl. 125a

barbiger Ridl. 9

baviensis (Drake) Pit. 112

bifloroideus H.Zhu 10

biflorus (Blume) M.Gangop. \& Chakrab. 11

bordeni Elmer $6 \mathrm{a}$

borneensis Merr. 12

brachyphyllus K.Schum. 6 a

bracteatus Wight 56

bracteolatus Miq. 13

bractescens Ridl. 37

var. rosulatus Ridl. 37

braunianus (Warb. ex Boerl.) M.Gangop. \&

Chakrab. (excl.)

brevidens Craib 59

brevipedicellatus H.Zhu 14

brevipedunculatus $\mathrm{H}$.Zhu 15

brevipes Valeton (dub.)

brochidodromus H.Zhu 16

bruneensis H.Zhu 17

bulusanensis Elmer 26

bunzanensis Shimizu 59

cailinianus $\mathrm{H}$.Zhu 18

caloneurus K.Schum. 102

canephoroides Wernham 26

capitatus Blume 19

subsp. pendulus (Ridl.) H.Zhu 93

caudiculatus Ridl. (dub.)

chinensis (Champ.) Benth. 20

var. odajimae (Masam.) Kaneh. 20

chinensis auct. 128

chlorocarpus K.Schum. 21

var. curvinervis Valeton 21

chryseus Ridl. 22

chrysoneurus (Korth.) Miq. 23

chrysophyllus Miq. 24

chrysotrichoides Valeton 25

chrysotrichus Lauterb. 25

cinnamomoides Miq. 102

clementis Merr. 26

condorensis Pierre ex Pit. 35

congesticymus H.Zhu 27

conspicuus Ridl. 28

constrictus Wight 29

var. latifolius Craib 29

copelandi Elmer $6 a$

cordatus Merr. 30

coriaceifolius $\mathrm{H}$.Zhu 31

coriaceus King \& Gamble 95

coronatus King \& Gamble 32

crassifolius Ridl. 95

crassinervis Ridl. 33

crinitus Hook.f. 34

culionensis Elmer (excl.)

cupreus Pierre ex Pit. 125a

curtisii King \& Gamble 35

cyaneus Merr. (excl.)
Lasianthus (cont.)

cyanocarpoides Valeton 36

cyanocarpus Jack 37

var. asperatus Pierre ex Pit. 56

var. Iucidus Pierre ex Pit. 56

var. novoguineensis Valeton 56

var. subsessilis King \& Gamble 37

cyanocarpus auct. 56

densifolius Miq. 6a, 6b

var. calycinus King \& Gamble 6a

var. latifolia King \& Gamble $6 a$

densifolius auct. $6 \mathrm{~b}$

depressineurus H.Zhu 38

dinghouanus H.Zhu 39

dinhensis Pierre ex Pit. 20

var. glabrescens Pierre ex Pit. 20

var. tonkinensis Pit. 20

ellipticus Wight 40

eriocalyx $\mathrm{H}$.Zhu 41

euneurus Stapf 42

everettii Merr. 56

fasciculus $\mathrm{H}$.Zhu 43

ferrugineus King \& Gamble 44

filiformis King \& Gamble 45

var. bracteata King \& Gamble 45

filipedunculatus H.Zhu 46

firmus Miq. (excl.)

flavicans King \& Gamble 102

flavinervius Ridl. 47

floresensis H.Zhu 48

fordii Hance 49

var. fordii $49 a$

var. microphyllus (Elmer) H.Zhu 49b

formosensis Matsum.

var. hirsuta Matsum. 35

foxworthyanus Craib 50

furcatoides $\mathrm{H}$.Zhu 51

furcatus (Miq.) Bremek. (dub.)

gainii M.Gangop. \& Chakrab. 11

glaber Ridl. 52

glaber Scheff. ex Valeton 101

glabrescens Miq. 23

gracilis King \& Gamble 11

griffithii Wight 53

var. griffithii $53 a$

var. latibracteata King \& Gamble 53a

var. scabridus (King \& Gamble) H.Zhu 53b

harveyanus King \& Gamble (dub.)

var. longifolia King \& Gamble (dub.)

hexandrus (Blume) Blume 54

hiiranensis Hayata $125 \mathrm{~b}$

hirsutisepalus H.Zhu 55

hirsutus (Roxb.) Merr. 56

hirtimarginatus H.Zhu 57

hirtus Ridl. 58

hispidulus (Drake) Pit. 59

hispidus Elmer (excl.)

hoaensis Pierre ex Pit. 23

humilis Elmer 106

inaequalis Blume 37

var. angustibractea Valeton 37

inodorus Blume 60

subsp. inodorus 60a

subsp. montigenus H.Zhu $60 \mathrm{~b}$

subsp. pubescens H.Zhu 60c

iteoides Valeton ex H.Zhu 61

iteophyllus Miq. 62

kamputensis Pierre ex Pit. 49a

kinabaluensis Stapf 63

kurzii Hook.f. 23

var. fulvus C.Y.Wu \& H.Zhu 89

var. howii H.S.Lo 23

var. sylvicola H.S.Lo 89
Lasianthus (cont.)

kurzii auct. 22

kwangtungensis Merr. 35

laevicaulis Kurz 56

laevigatus Blume 64

lancilobus $\mathrm{H}$.Zhu 65

langkokensis (Drake) Pit. 112

latifolius (Blume ex DC.) Miq. 66

laxifloroideus H.Zhu 67

laxiflorus Merr. 68

ledermannii Valeton 69

lei Merr. \& Metc. ex H.S.Lo 125b

leucocarpus (K.Schum. \& Lauterb.) M.Gangop.

\& Chakrab. (excl.)

linearifolius H.Zhu 70

longibracteatus H.Zhu 71

longifolius Wight 72

subsp. laevis H.Zhu $72 b$

subsp. longifolius $72 a$

var. obtusifolius H.Zhu 72c

lowianus King \& Gamble (dub.)

lucidus Blume 73

lucidus King \& Gamble (dub. \& syn.)

maingayi Hook.f. 102

var. hirta Ridl. 104

malaccensis King \& Gamble 74

malaiense $\mathrm{H}$.Zhu 75

megaphyllus $\mathrm{H}$.Zhu 76

membranaceoideus H.Zhu 77

membranaceus Stapf 78

var. firma Stapf 78

microphyllus Elmer 49b

minahassae Koord. (excl.)

mindanaensis Merr. 112

minutiflorus H.Zhu 79

mollis Ridl. 80

montanus King \& Gamble (dub.)

morus Elmer 128

mucronulatus (Korth.) Miq. 81

var. lineata Miq. 115

multibracteatus Wernham (excl.)

myrtifolius Ridl. 82

subsp. myrtifolius $82 \mathrm{a}$

subsp. vicarius $H$.Zhu $82 b$

neglectus Valeton ex Bakh.f. 26

nervosus King \& Gamble 83

nigrescens H.Zhu 84

nigrocarpus Masam. 128

novoguineensis (Warb. ex Boerl.) M.Gangop.

\& Chakrab. (excl.)

obliquinervis Merr. 85

subsp. novoguineensis H.Zhu $85 \mathrm{~b}$

subsp. obliquinervis $85 a$

var. taitoensis (Shimizu) T.S.Liu \& J.M.Chao 128

obliquinervis auct. 128

oblongatus Merr. 86

oblongus King \& Gamble 87

obovatibracteatus H.Zhu 88

obscurus (Blume ex DC.) Miq. 89

oculus-cati Miq. 56

ovatus (Korth.) Miq. (dub.)

var. oligoneurus (Korth.) Boerl. (dub. \& syn.)

palawanensis $\mathrm{H}$.Zhu 90

palembanicus Miq. 81

papuanus Wernham 91

pedicellatus $\mathrm{H}$.Zhu 92

pendulus Ridl. 93

perakensis King \& Gamble 94

var. kalimantanensis H.Zhu 94b

var. perakensis $94 a$

pergamaceus King \& Gamble 95

phymatodeus H.Zhu 96 


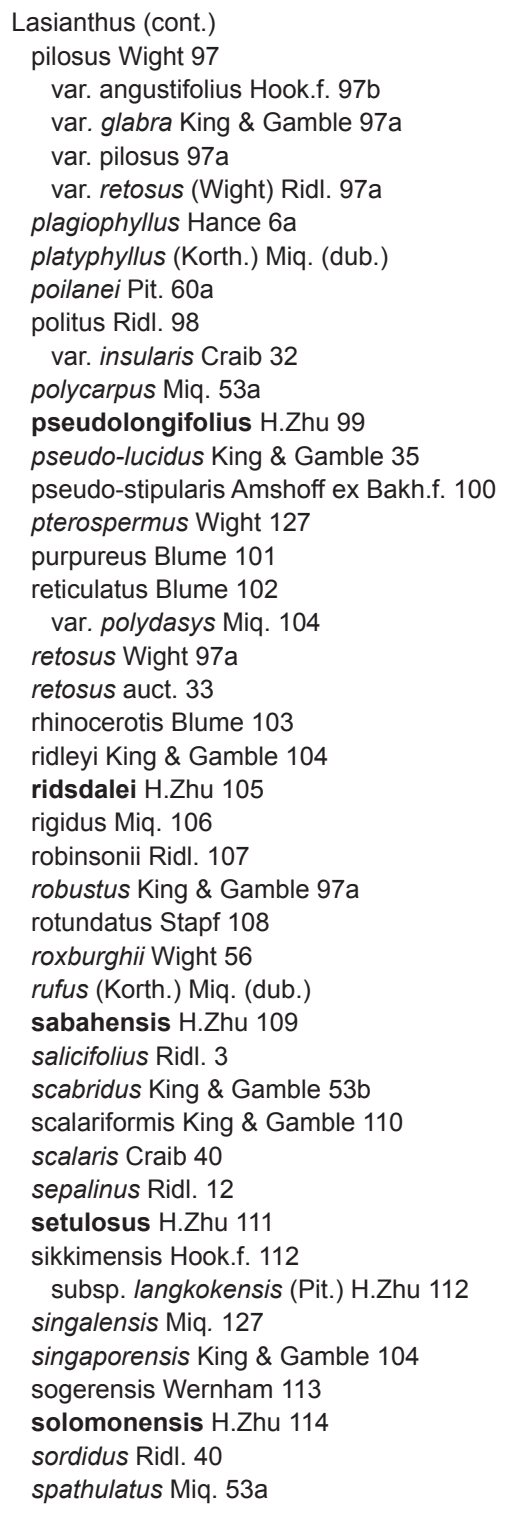

Lasianthus (cont.)

stercorarius Blume 115

var. borneensis Miq. ex Valeton \& Winkler 81 var. palembanicus (Miq.) Miq. 81

var. polypleura Blume ex Miq. 115

stercorarius auct. 23

sterrophyllus Merr. 116

stipularis Blume 117

var. hirtus Ridl. (dub.)

var. novoguineensis Valeton 117

subaureus Craib 118

subglobosus H.Zhu 119

subinaequalis King \& Gamble 37

submembranifolius Elmer 120

subsessilis Miq. 128

subspicatus King \& Gamble (excl.)

sumatraensis $\mathrm{H}$.Zhu 121

sylvestris Blume 128

var. latifolia Miq. 125b

var. subsessilis (Miq.) Miq. 128

sylvestroides Valeton 122

taitoensis Shimizu 128

tamirensis Pierre ex Pit. 128

tashiroi Matsum. 49a

tentaculatus Hook.f. 106

tenuifolius H.Zhu 123

tobingensis Miq. (excl.)

tomentosus Blume 124

var. hiiranensis (Hayata) H.Zhu 125b

tomentosus auct. $125 \mathrm{~b}$

tonkinensis (Drake) Pit. 6a

trichophlebus Hemsl. 125

subsp. barbellatus (Ridl.) H.Zhu 125a

var. latifolius (Miq.) H.Zhu 125b

var. trichophlebus $125 \mathrm{a}$

truncatus Bedd. 128

tsangii Merr. ex Li 112

tubiferus Hook.f. 60a

umbellatus Kuntze 101

undulatus H.Zhu 126

velutinus Ridl. 40

venosus Blume 127

venosus auct. 131

venulosus Ridl. 40

verticillatus (Lour.) Merr. 128

var. taitoensis (Shimizu) H.Zhu 128

villosus Ridl. (excl.)
Lasianthus (cont.)

vriesianus Miq. 129

vulcanicus Ridl. 130

wallichii (Wight \& Arn.) Wight 6a

subsp. plagiophyllus (Hance) C.Y.Wu \& H.Zhu

$6 a$

var. penangensis Hook.f. 32

var. setosus (Craib) C.Y.Wu \& H.Zhu 6a

wightianus Hook.f. 131

wrayi King \& Gamble 128

zambalensis Elmer 49a

Litosanthes biflora Blume 11

brauniana Warb. (excl.)

gracilis Hayata 11

leucocarpa K.Schum. \& Lauterb. (excl.)

novoguineensis Warb. ex Boer. (excl.)

Mephitidia apiocarpa Korth. (dub.\& syn.)

attenuata (Jack) DC. 6a

baviensis Drake 112

var. glabra Korth. $6 a$ capitata (Blume) DC. 19

var. ferruginea Korth. 22

chinensis Champ. 20

chrysoneura Korth. 23

hexandra Blume 54

hispidulus Drake 59

inodara (Blume) DC. 60a

langkokensis Drake 112

latifolia Blume ex DC. 66

lucida (Blume) DC. 73

mucronulata Korth. 81

obscura Blume ex DC. 89

odajimae Masam. 20

ovata Korth (dub.\& syn.)

var. oligoneura Korth. (dub.\& syn.)

plagiophylla (Hance) Nakai $6 a$

platyphylla Korth. (dub.\& syn.)

rufa Korth. (dub.\& syn.)

stipularis Korth. 117

tashiroi (Matsum.) Nakai 49a

var. kotoensis Nakai ex Saski 49a

tonkinensis Drake 6a

wallichii Wight \& Arn. $6 a$

Nonatelia? hispida Wall. ex Roxb. $6 a$

Plectronia culionensis Merr. (excl.)

Santia Wight \& Arn.

var. microphyllus (Elmer) H.Zhu 49b

Triosteum hirsutum Roxb. 56 